Universidad de Lima

Escuela de Posgrado

Maestría en Derecho Empresarial

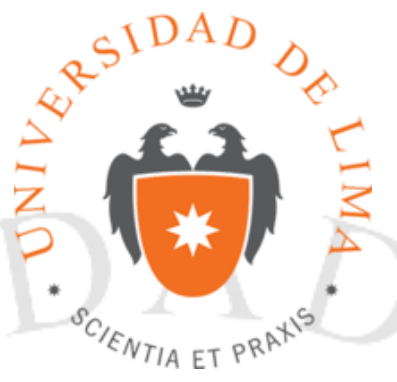

\title{
LA RELACIÓN ESTADO EMPLEADOR - SERVIDORES PÚBLICOS Y EL DERECHO A LA NEGOCIACIÓN COLECTIVA EN LA ADMINISTRACIÓN PÚBLICA
}

Trabajo de Investigación para optar por el Grado de Maestro en Derecho Empresarial

\author{
Carlos Enrique Haro Vargas
}

Código 20051793

$$
\text { Lima - Perú }
$$

Diciembre de 2016 


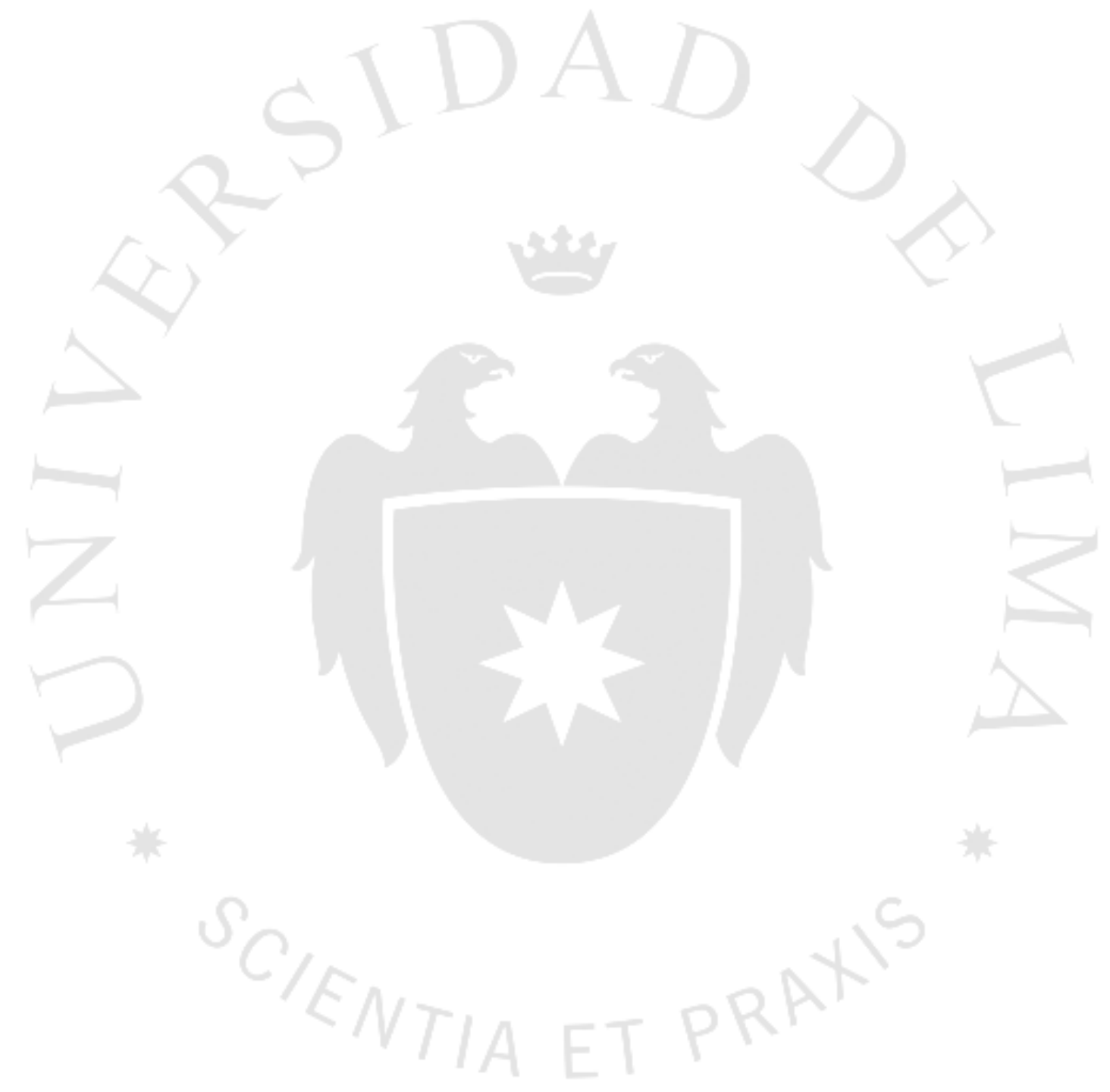




\section{LA RELACIÓN ESTADO EMPLEADOR - SERVIDORES PÚBLICOS Y EL DERECHO A LA NEGOCIACIÓN COLECTIVA EN LA ADMINISTRACIÓN PÚBLICA}




\section{TABLA DE CONTENIDO}

INTRODUCCIÓN ...........................................................................................................1

CAPITULO 1: PLANTEAMIENTO DEL PROBLEMA ...................................................3

1.1. Realidad problemática ...................................................................... 3

1.2.Formulación del problema............................................................... 6

1.3.Supuestos Teóricos ...................................................................... 6

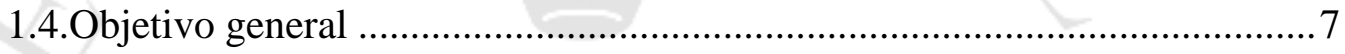

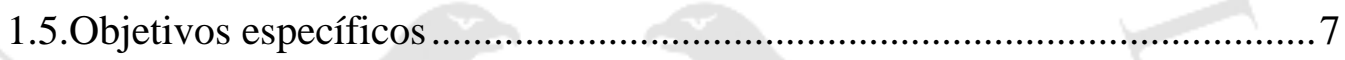

CAPÍTULO 2: MARCO TEÓRICO.......................................................................8

2.1.Naturaleza Jurídica de la relación Estado Empleador y el Servidor Público8

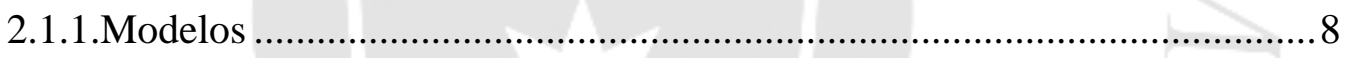

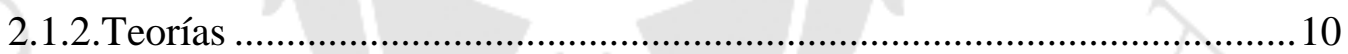

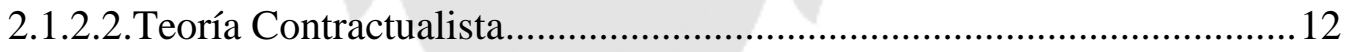

2.2.Antecedentes sobre el régimen laboral del empleo público ....................... 13

2.2.1.Aspectos históricos ....................................................................... 13

2.2.2.Antecedentes bibliográficos nacionales e Internacionales ...................... 15

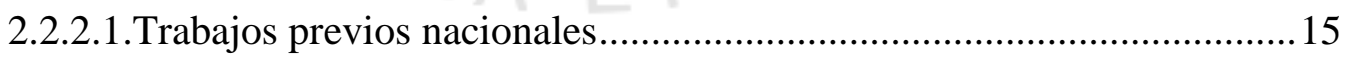

2.2.2.2.Trabajos previos internacionales ................................................. 16

CAPÍTULO 3: LA NECESIDAD DE ORDENAR EL SISTEMA NACIONAL DE

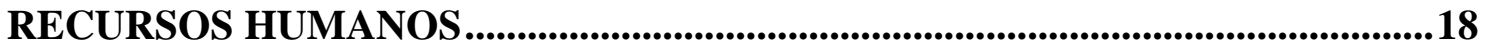

3.1. Situación poblacional ........................................................................ 18 
3.2. Pluralidad de regímenes.

3.3. Caos Normativo e Inconsistencia de la Carrera Administrativa. 20

3.4.La Ley del servicio Civil - Marco Normativo.

3.5.Análisis de los derechos laborales de los Servidores Civiles. .23

3.5.1.Comparación con otros regímenes laborales existentes .23

CAPÍTULO 4: EL DERECHO A LA NEGOCIACIÓN COLECTIVA EN EL RÉGIMEN COMÚN Y EN RÉGIMEN DEL SERVICIO CIVIL ............................28

4.1.La Negociación Colectiva: Aspectos Generales........................................28

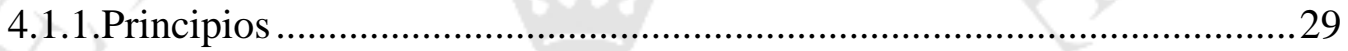

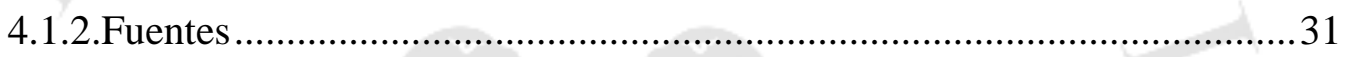

4.2.Etapas del Procedimiento de la Negociación Colectiva ................................35

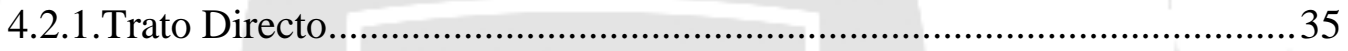

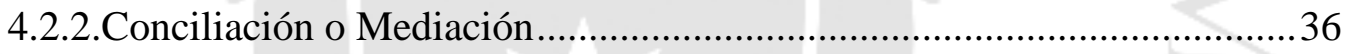

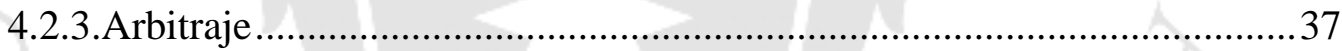

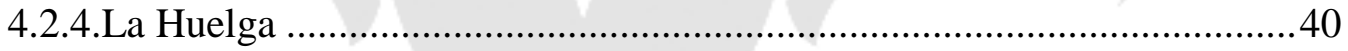

4.4.El procedimiento de negociación colectiva en el régimen del Servicio Civil. 45

4.4.1.El procedimiento directo de la negociación colectiva en el Servicio Civil] 47

4.4.1.1.Negociación directa .47

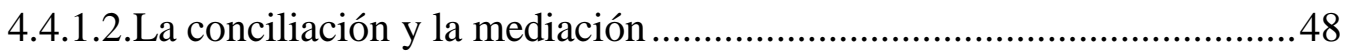

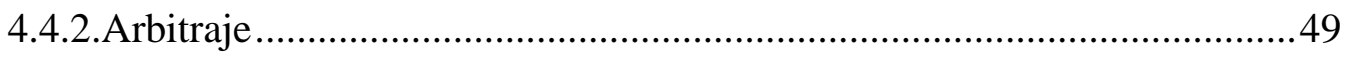

4.4.3.El Procedimiento de huelga en el Servicio Civil .....................................53 
4.4.4.Diferencias entre la negociación colectiva en el régimen de la actividad privada y en el régimen del Servicio Civil

4.4.4.1. Un nuevo actor en el procedimiento en el procedimiento de negociación colectiva en la Ley de Servicio Civil: La Comisión de Apoyo al Servicio Civil

- CASC.

4.4.4.2.Limites a los plazos por razones de orden presupuestal .62

4.4.4.3.Los servicio indispensables adicionales a los servicios esenciales.

4.4.4.4.Facultad de contratación de personal de las entidades en casos de huelga en la administración pública

\section{CAPÍTULO 5: LAS CONDICIONES ECONÓMICAS EN LA NEGOCIACIÓN COLECTIVA DE LA ADMINISTRACIÓN PÚBLICA}

5.1.Nuevos Parámetros de Negociación: Condiciones de Empleo y los fundamentos que lo sustentan.

5.2.Inconsistencias observadas en la Ley 30057, Ley del Servicio Civil relacionadas con la Negociación Colectiva.

5.3.Puntos de vista de juristas y docentes universitarios y entidades públicas relacionadas al tema.

5.3.1.Argumentos a favor de la negociación Colectiva de los servidores públicos

5.3.2.Argumentos en contra.

5.3.3.Punto de vista intermedio .78

5.4.Jurisprudencia del TC relacionadas al tema

5.4.1.STC del TC EX 00018-2013-PI/TC respecto a la inconstitucionalidad de la Ley 30057 .79

5.4.2.STC del TC recaída en EX 00003-2013-PI/TC y otras demandas de inconstitucionalidad contra el artículo 6 de la ley 29812- Ley de Presupuesto81 
5.4.3.STC recaída en el Expediente 0025-2013-PI/TC, 003-2014-PI/TC, 0082014-PI/TC y 017-2014-PI/TC

\section{CAPITULO 6: LA NEGOCIACIÓN COLECTIVA EN EL ÁMBITO}

INTERNACIONAL

.91

6.1.La Negociación Colectiva y la Organización Internacional del Trabajo OIT...

6.2.Los Convenios OIT relacionados a la Negociación Colectiva .93

6.3.Regímenes de la negociación colectiva en diversos países de la región .....97

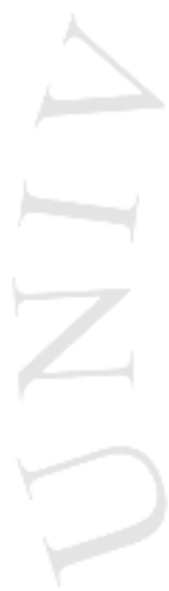




\section{ÍNDICE DE ANEXOS}

Anexo 1. Convenio $\mathrm{N}^{\circ} 087$ de la OIT.

$\begin{array}{lll}\text { Anexo 2. Convenio No } 98 \text { de la OIT } & 114\end{array}$

$\begin{array}{lll}\text { Anexo } 3 & \text { Convenio No } 151 \text { de la OIT. } & 117\end{array}$

$\begin{array}{lll}\text { Anexo } 4 & \text { Convenio } N^{\circ} 154 \text { de la OIT } & 121\end{array}$

$\begin{array}{ll}\text { Anexo 5. Ley 30057, Ley del Servicio Civil. } & 123\end{array}$

Anexo 6. TUO del Decreto ley 25593, Ley de Relaciones Colectivas. $\quad 167$

$\begin{array}{lll}\text { Anexo } 7 & \text { STC Exp. 00018-2013-PI/TC. } & 186\end{array}$

Anexo 8 STC Exp. 003-2013-PI/TC $=226$

$\begin{array}{lll}\text {.Anexo } 9 \quad \text { STC Exp. 025-2013-PI/TC } & 318\end{array}$ 


\section{INDICE DE TABLAS}

Tabla 1.1 Proyectos de ley que proponen el retiro del ámbito de la Ley 30057, Ley del Servicio Civil

Tabla 2.1 Comparación de modelos de la Función Pública $\quad 9$

Tabla 3.1 Cuadro Comparativo Población 20

Tabla 3.2 Comparación de Derechos Individuales entre los Diferentes Regímenes Laborales Y El Servicio Civil

Tabla 4.1 Evolución de La normatividad del Derecho a la Negociación

Colectiva

Tabla 4.2. Procedimiento arbitral potestativo en la Ley 30057 - Ley del Servicio Civil y su reglamento. Aplicación supletoria: LRCT-Art. Del $63^{\circ} \mathrm{Al} 67^{\circ}$

Tabla 4.3. Comparativo del derecho de huelga en el régimen laboral privado y en el servicio público

Tabla 5.1. Comparativo entre la norma legal sobre negociación

colectiva en el servicio civil anterior y la posterior a la sentencia del Tribunal

Tabla 5.2. Comparativo entre la norma reglamentaria sobre negociación colectiva en el servicio civil anterior y la posterior a la sentencia del Tribunal Constitucional

Tabla 5.3. Lineamientos que orientarán la negociación colectiva económica en la administración pública constitucional (1)

Tabla 5.4. Lineamientos que/ orientarán la negociación colectiva económica en la administración pública constitucional (2)

Tabla 6.1.. Convenios OIT ratificados por los países de la región

Tabla 6.2. Regímenes de negociación colectiva en países de América 98 Latina 


\section{ÍNDICE DE FIGURAS}

$\begin{array}{lll}\text { Figura 3.1. } & \text { Los Servidores Civiles según su régimen laboral } & 18\end{array}$

Figura 3.2. Evolución del número de servidores públicos por año (en 21 miles)

Figura 4.1. Flujograma General De La Negociación Colectiva

Tuo Del D. Ley N 25593 - Reglamento D.S. 011-92-Tr

Figura 4.2. Flujograma general de la Negociación Colectiva -Régimen Servicio Civil

Figura 4.3. Flujograma de la procedencia y legalidad de la huelga en el Servicio Civil

Figura 4.4. Flujograma de la Negociación Colectiva en el Servicio Civil 


\section{INTRODUCCIÓN}

En los últimos años la realidad de los trabajadores de la Administración Pública ha cambiado en razón a la aplicación de nuevas normas que han modificado sustancialmente el sistema de contratación de personal.

Desde los inicios del Siglo XX se han venido emitiendo diversas normas relacionadas a la Gestión de Recursos Humanos en la Administración Pública, sin embargo, a partir del año 2008, se han emitido normas buscando lograr la homogeneidad de los diferentes regímenes laborales en el Sector Público. Entre estas normas podemos mencionar el Decreto Legislativo 1023, Ley que crea la Autoridad Nacional del Servicio Civil, Decreto Legislativo 1024, Ley que crea el Cuerpo de Gerentes Públicos, el Decreto Legislativo 1057 Ley regula el régimen especial de Contratación Administrativa de Servicios.

El 4 de Julio 2013 se emitió la Ley 30057, Ley del Servicio Civil, que dispuso la más importante regulación de la Administración Pública en los últimos años. Casi un año después, se emitieron los tres reglamentos a través de los Decretos Supremos 0402014-PCM (Reglamento General), 041-2014-PCM (Reglamento del Régimen Especial para Gobiernos Locales) y 138-2014-EF (Reglamento de Compensaciones de la Ley del Servicio Civil), otorgando así todo el marco normativo necesario para implementar el régimen de Servicio Civil recién creado en la Administración Pública.

Si bien las normas señaladas tienen como fin superior la eficiencia del servicio como centro de interés de la Administración Pública, en beneficio de los ciudadanos, no es menos cierto que dicha normatividad en su Capítulo Sexto, establece disposiciones relacionadas a la Negociación Colectiva, donde se observa con preocupación que se afectaría derechos constitucionales y supranacionales sobre ésta materia.

La presente investigación trata de analizar los antecedentes, la doctrina, normatividad constitucional, legal y la jurisprudencia respecto a la relación laboral atípica entre el Estado como empleador y los servidores civiles y en especial el impacto de la Ley vigente en el Derecho a la Negociación Colectiva en la Administración 
Pública, proponiéndose algunos mecanismos para encausar y solucionar dicha problemática.

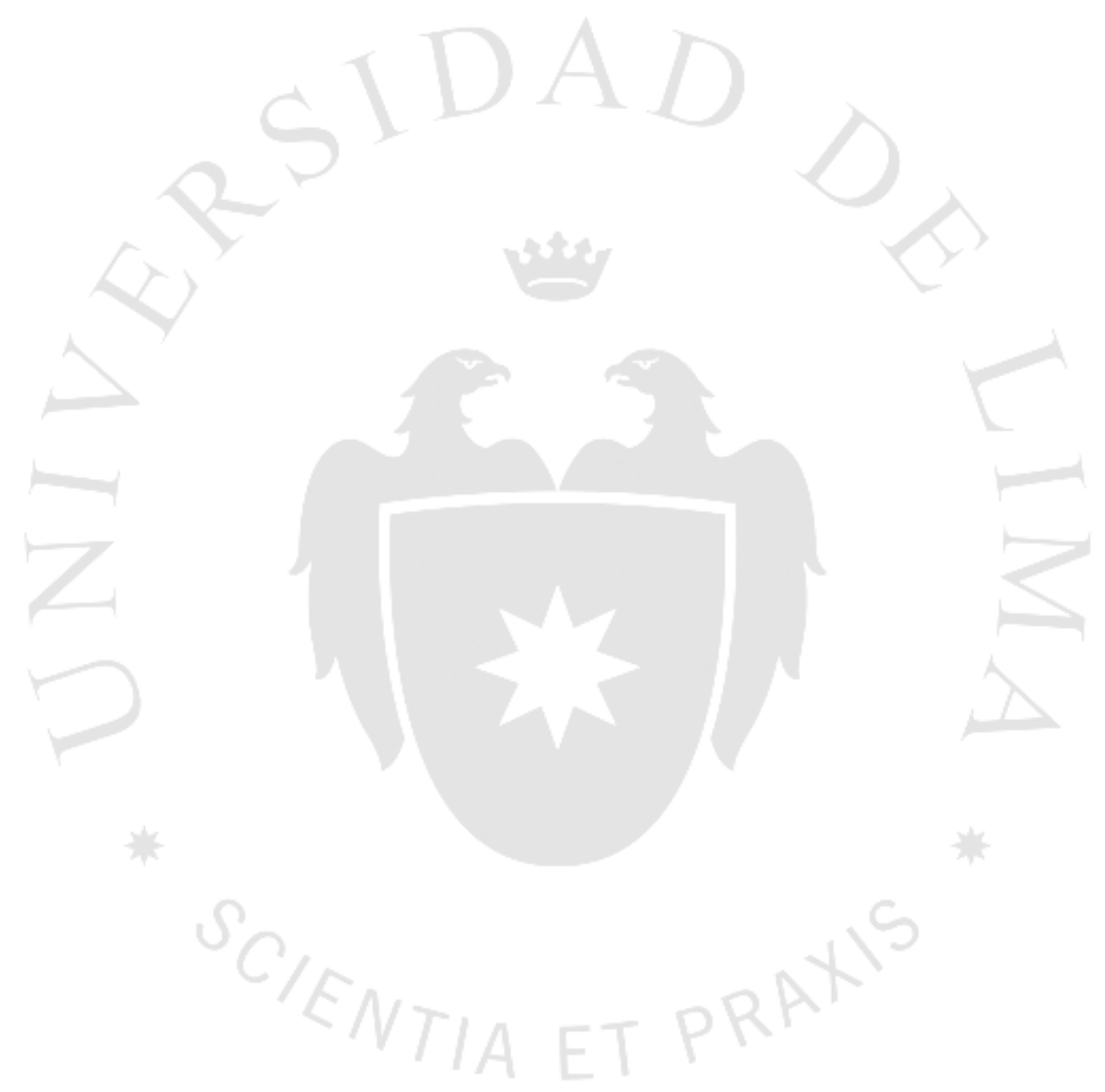




\section{CAPITULO 1: PLANTEAMIENTO DEL PROBLEMA}

\subsection{Realidad problemática}

El problema se ha graficado en las recientes y constantes exigencias realizados por organizaciones de servidores públicos, las autoridades de los entes autónomos, y congresistas de la República en contra de la vigencia de la Ley 30057, Ley del Servicio Civil que reafirma a la Autoridad Nacional del Servicio Civil (SERVIR), entidad adscrita a la Presidencia del Consejo de Ministros (PCM), como ente rector del Sistema Integral de Administración de los Recursos Humanos en el Estado. Con esta norma y sus reglamentos se busca regular el desempeño del personal del empleo público en busca de la eficiencia en el desarrollo de las políticas públicas para una mejor prestación de servicios a la ciudadanía.

No obstante de lo antes expuesto, se ha observado que la Ley del Servicio Civil afecta derechos individuales y colectivos de los servidores públicos, en especial el derecho a la negociación colectiva, situación que ha originado numerosas manifestaciones de rechazo de las organizaciones sindicales en la Administración Pública, de algunas autoridades de los organismos constitucionalmente autónomos, congresistas de la República y colegios profesionales, lo que se evidencia con la presentación de cinco acciones de inconstitucionalidad ante el Tribunal Constitucional.

La Ley 30057 ha regulado el derecho a la negociación colectiva de los servidores civiles en sus artículos del 43 al $44^{1}$ prohibiendo claramente la negociación de remuneraciones considerando sólo "condiciones de empleo". Así, el artículo 42 establece:

Artículo 42. De las solicitudes de cambio de condiciones de trabajo o condiciones de empleo. Los servidores civiles tienen derecho a solicitar la mejora de sus compensaciones no económicas, incluyendo el cambio de condiciones de trabajo, de acuerdo con las posibilidades presupuestarias y de infraestructura de la entidad y la naturaleza de las funciones que en ella se cumplen.

\footnotetext{
${ }^{1}$ El Tribunal Constitucional, en sus Sentencia recaída en el expediente $\mathrm{N}^{\circ} 0025-2013-\mathrm{PI} / \mathrm{TC}$ y otros, del 26 de abril de 2016 que declaró inconstitucional diversos artículos de la ley 30057 relacionados a la prohibición de la negociación colectiva relacionado a las condiciones económicas.
} 
El artículo 42 de la Ley pretendía cambiar el término "pliego de reclamos" utilizada en la negociación colectiva en el régimen laboral privado y en el régimen del Decreto Legislativo 276, por el de "solicitudes de cambio de condiciones de trabajo o condiciones de empleo". Cambiar la palabra "reclamo" por "solicitud" tiene un subliminal mensaje. No debemos olvidar que los derechos se reclaman, se exigen y no se solicitan, en razón a que esta última palabra tiene una connotación rogatoria.

Aquí se estaba excluyendo de la negociación a las compensaciones económicas y las demás condiciones de trabajo.

El artículo 44 de la Ley establecía que la negociación colectiva se debe sujetar a los siguientes aspectos:

a) El pliego de reclamos se presenta ante la entidad pública entre el 1 de noviembre y el 30 de enero del siguiente año.

El fin de este mandato es adaptar el procedimiento a los tiempos establecidos para la aprobación del Presupuesto General de la República del siguiente año.

b) La contrapropuesta o propuestas de la entidad relativas a compensaciones económicas son nulas de pleno derecho. (...)"

Este literal se relaciona con lo que se establecía en el tercer párrafo del artículo 40, en el literal e) del artículo 43 y en el literal b) del artículo 44 de la 30057, Ley del Servicio Civil.

Esta problemática se ha evidenciado numerosas quejas y reclamaciones de relaciones sindicales de servidores públicos, las mismas que se han traducido en numerosos proyectos de Ley que proponen salirse del ámbito del régimen de servicio civil porque según esto se afecta sus derechos laborales fundamentales, entre ellos la negociación colectiva. Entre ellos podemos señalar los siguientes: proyectos de ley señalados en la tabla 1.1. 
Tabla 1.1

Proyectos de ley que proponen el retiro del ámbito de la Ley 30057, Ley del Servicio Civil

$\mathbf{N}^{\circ}$ PROYECTO

\begin{tabular}{ll}
\hline 03882/2014-CR & Lescano Ancieta Yonhy,Guevara \\
& Amasifuen Mesias Antonio,Inga \\
& Vasquez Leonardo Agustin,Mavila \\
& Leon Rosa Delsa y otros.
\end{tabular}

Lescano Ancieta Yonhy, García

Belaunde Víctor Andrés, Guevara

Amasifuen Mesias Antonio y otros.

SUMILLA

Propone modificar la Primera Disposición Complementaria Final de la Ley del Servicio Civil Ley 30057, que excluye a los trabajadores de la Superintendencia del Mercado de Valores de la Ley del Servicio Civil.

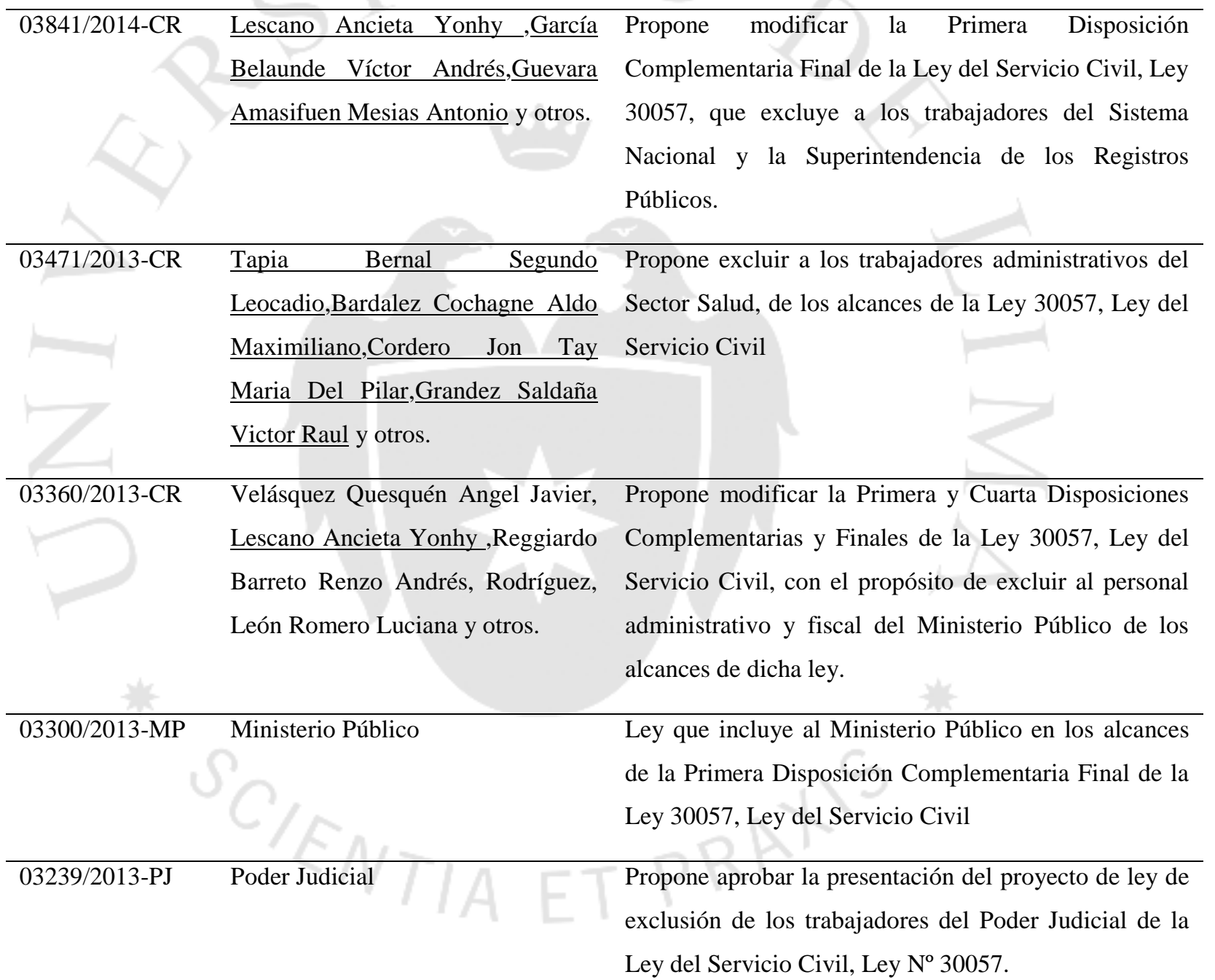

Propone Ley que incluye a los servidores civiles del tribunal constitucional en los alcances de la primera disposición complementaria final y modifica la cuarta disposición complementaria de la Ley 30057, Ley del Servicio Civil. 
Pluralidad de Regímenes y cantidad de Trabajadores del Sector Público

La Ley del Servicio Civil, Ley 30057 y sus reglamentos fueron promulgados con el fin de otorgar un régimen único de contratación de Recursos Humanos en la Administración Pública, dichas normas ordenan el sistema centralizando el Servicio Público dentro de los marcos de la eficiencia, eficacia, real progresión de méritos, con el fin de otorgar una atención de calidad a los ciudadanos.

Sin embargo dentro de los disposiciones normativas promulgadas se ha evidenciado un gran retroceso en razón a la negociación colectiva, atacando así los derechos fundamentales establecidos en la Constitución Política de Huelga y de Negociación Colectiva de los trabajadores.

El presente trabajo busca evidenciar los problemas de la Ley del Servicio Civil relacionado a la Negociación Colectiva y de esa forma proponer nuevos mecanismos y un cambio normativo relacionado a este punto.

\subsection{Formulación del problema}

El problema de investigación se puede formular con las siguientes interrogantes:

A. ¿Cuáles son los fundamentos jurídicos que permiten confirmar la afectación del derecho de negociación colectiva de los servidores públicos en la Administración Pública peruana actual.

B. ¿Cuáles son los modelos teóricos de la relación Estado empleador-Servidor público en la Administración Pública peruana que explican la regulación actual del derecho a la negociación colectiva en la Ley 30057, Ley del Servicio Civil.

C. ¿Cuáles son los fundamentos presupuestales que justificarían la afectación del derecho de negociación colectiva de los servidores públicos que explican la regulación actual del derecho a la negociación colectiva en la Ley 30057, Ley del Servicio Civil

\subsection{Supuestos Teóricos}


El Nuevo Régimen del Servicio Civil, establecido por la Ley 30057, afecta negativamente al derecho a la negociación colectiva de los servidores públicos al prohibírsele negociar condiciones de carácter económico.

El Estado, al establecer el Nuevo Régimen de Servicio Civil (en adelante NRSC) se ha sustentado en la teoría estatutaria de la relación Estado - Empleador.

El Estado al establecer la prohibición de la negociación colectiva en materia remunerativa en el NRSC se ha sustentado en el principio de Provisión Presupuestaria establecido en la Constitución Política del Perú.

\subsection{Objetivo general}

Demostrar jurídicamente que la aplicación del nuevo régimen del servicio civil establecido por la Ley 30057, Ley del Servicio Civil colisiona con el derecho a la negociación colectiva afectando a los servidores públicos del Perú.

\subsection{Objetivos específicos}

Comprender los modelos y teorías que explican la conducta del Estado empleador al regular el derecho a la negociación colectiva en la Ley 30057, Ley del Servicio Civil.

Comprender los fundamentos presupuestales que explican la conducta del Estado empleador al regular el derecho a la negociación colectiva en la Ley 30057, Ley del Servicio Civil. 


\section{CAPÍTULO 2: MARCO TEÓRICO}

\subsection{Naturaleza Jurídica de la relación Estado Empleador y el Servidor Público}

\subsubsection{Modelos}

Cuando el Estado Antiguo evoluciona hacia el Estado Moderno la organización en la Administración Pública de los nuevos Estados se bifurcan en el modelo abierto, con amplia discrecionalidad de la autoridad política en ejercicio y el Modelo Cerrado, en la que se mantiene una burocracia permanente, en que la discrecionalidad de la Autoridad Política es restringida.

El Modelo Abierto fue la característica del gobierno de los Estados Unidos desde el inicio de la República. Este modelo no reconoce la existencia de una clase burocrática: es el gobierno de turno el que tiene las atribuciones de elegir libremente al personal del empleo público, tal como lo expresa Haro Carranza (2014):

Este sistema de patronazgo tenía su fundamento, aunque hoy eso no pueda ser entendido así, en la propia noción del sistema democrático por el cual el gobierno de turno debe ocupar todos los empleos públicos con el fin de poner en marcha el plan por el que el pueblo ha votado. (p. 9)

Respecto al modelo cerrado, siguiendo a Sanchez Morón (1997), éste tuvo su origen en la Francia post revolucionaria:

La idea de poner en pie instituciones estables, permanentes y duraderas, situadas al margen de las luchas políticas, por contraposición a las convulsiones del período revolucionario, es lo que sostiene esta concepción de la función pública que, por lo demás, enlaza con ideas y regulaciones ya presentes en el antiguo régimen y es perfectamente coherente con la nueva estratificación social y el predominio absoluto de la burguesía que surge de la revolución. (p. 34)

En la actualidad el sistema cerrado tiene como contenido característico que el ingreso deba realizarse mediante procesos de selección públicos en los que se evalúa el mérito y la capacidad, ingresando a un cuerpo o escalas determinadas, divididas en categorías a 
las que se va ascendiendo, y garantizándose una estabilidad laboral absoluta (propiedad del cargo).

La siguiente tabla puede graficar los modelos antes mencionados:

Tabla 2.1.

Comparación de modelos de la Función Pública

Modelo Abierto

Modelo Cerrado

Fuente: Elaboración propia

Actualmente podemos evidenciar que estos modelos no se presentan como únicos en los Estados, debemos ver que los países utilizan un sistema mixto relacionado a los modelos indicados en el Tabla 2.1.

En el caso del Perú podemos observar que existen diversos marcos normativos de contratación de personal en el sector público. Las diversas normas de contratación de personal evidencian que nos encontramos ante un sistema mixto, el cual combina elementos de ambos sistemas, existe un régimen de contratación que se da a través de concursos públicos, los cuales requieren dentro del perfil ciertos requisitos para el puesto. Del mismo modo un sistema abierto, el cual el Estado puede colocar a un personal de confianza, definido por la Ley Marco del Empleo Público (Ley 28175) como aquel trabajador que desempeña un cargo de confianza, técnico o político, distinto al del funcionario público que se encuentra en el entorno de quien lo designa o remueve libremente y en ningún caso será mayor al $5 \%$ de los servidores públicos existentes en cada unidad. En ese sentido, quien se encuentre en el puesto de poder puede elegir al personal a discreción.

El Empleo Público está conformado por personas que desarrollan su actividad dentro de la administración pública, vale decir es el personal que desarrolla actividades en el Estado con el fin de atender al ciudadano en diferentes cadenas de organización.

En efecto cuando, hablamos de Empleo Público nos referimos a las actividades que se realizan en la administración pública, que tienen carácter organizacional, 
estructural, la misma que conlleva a procedimientos dentro de las actividades cotidianas de los ciudadanos.

\subsubsection{Teorías}

De conformidad con Haro Carranza (2014, p. 12), son diversas las corrientes doctrinarias que se han manifestado sobre la naturaleza jurídica de la relación de empleo público. Inicialmente se sostuvo que se trataba de un acto unilateral del Estado, al cual daba validez o eficacia el consentimiento del administrado; así la situación jurídica del agente y empleado tenía forma legal o reglamentaria. Por otro lado se señaló que en origen era un acto jurídico bilateral, importando la voluntad del agente pero sin formalizar un contrato, en tanto que la relación subsecuente se encuadraba en lo estatutario, pudiendo la administración modificarla unilateralmente. Posteriormente surgió la corriente que defendía la tesis de que la naturaleza de esta relación era la contractual es decir una relación laboral común, con plena autonomía de las partes pero con algunas particularidades.

Para Miranda (2004, p. 5), la dogmática administrativa, administrativista y laboralista en el Perú no han confluido en un escenario para su deslinde como si ocurrió en Europa Continental por el poco desarrollo doctrinario en el primero de los casos. Afirma que, la ausencia de doctrina sobre el tema ha dejado un terreno libre para el legislador y la judicatura produciendo resultados incoherentes sin una adecuada valoración de los intereses concurrentes. En términos generales, el legislador ha mostrado su proclividad por fórmulas del derecho administrativo, en donde se siente más cómodo para imponer condiciones, y ha "huido" a los textos normativos de derecho laboral privado, cuando este derecho administrativo contradictoriamente ralentizaba o volvía rígido su proceso de toma de decisiones, aunque dicha "huida" fue para refugiarse imponiendo sus condiciones de autoridad, muchas veces contradictorias con el derecho del trabajo

Estas dos posiciones, que a lo largo de las últimas décadas del siglo pasado, vienen enfrentando sus fundamentos doctrinarios, constitucionales; respecto a su visión sobre los fines del Estado, tienen importantes puntos de vista que colisionan entre sí. 


\subsubsection{Teoría Unilateralista o Estatutaria}

La Teoría Unilateralista llamada también Estatutaria se originó en los amplios estudios del distinguido jurista alemán Otto Mayer, en especial en las reformas especiales de sujeción del Estado, recogidos por los sistemas jurídicos de los diferentes paises de Europa y en el en el caso peruano, a través de la Ley 11377, Estatuto y Escalafón del Servicio Civil.

Siguiendo a Haro Carranza (2014, p. 53) la teoría estatutaria, ha sido defendida por importantes autores franceses como Maurice Hauriou, Gastón Jèze y Duguit, que tuvo una fuerte aceptación en el ámbito internacional; sin embargo, la teoría contractualista ha comenzado a disminuirla. Estos autores manifiestan que el estatuto legal tiene un acto unilateral de autoridad del Estado en el que para nada interviene la voluntad del funcionario o empleado, a no ser para aceptar el cargo, en cuyo caso no es otra cosa que la adhesión a un hecho consumado.

Al respecto se deben entender que quedan algunos rezagos de la Teoría Estatutaria en el Decreto Legislativo 276 Ley de Bases de la Carrera Administrativa y de Remuneraciones del Sector Público y sus normas reglamentarias.

La Teoría Estatutaria faculta al Estado para imponer al funcionario vinculaciones jerárquicas, en este caso, muchas veces los derechos fundamentales de los trabajadores quedan de lado, subordinados a las necesidades del servicio. Tales limitaciones puede imponerlas la administración incluso al margen de la ley y en otros casos dentro de una ley inconstitucional impuesta por el Estado empleador.

Este modelo se caracterizaba en el caso peruano porque postulaba a una relación desequilibrada en cuanto al nivel de autoridad: El Estado dispone, el servidor obedece; el empleo público se constituye y se extingue por un acto unilateral de nombramiento; la regulación de éste sólo le corresponde al Estado; los trabajadores no tienen capacidad de negociación o lo tienen sumamente restringidos; sólo pueden agruparse para fines sociales y culturales, mas no para acciones sindicales, tal como lo estipulaban diversas normas sobre la materia en especial el Decreto del 12 de noviembre de 19452 y la Ley 11377, Ley del Estatuto y Escalafón del Servicio Civil del año 1950, que

2. El Decreto del 12 de noviembre de 1945, estableció "las asociaciones de empleados públicos no se llamarían sindicatos". 
restringían el derecho a la sindicalización, a la negociación colectiva y a la huelga de los servidores públicos.

\subsubsection{Teoría Contractualista}

La Teoría Contractualista, también conocida como Derecho Laboral, se contrapone con la Teoría Estatutaria, al establecer que la relación entre el Estado y sus trabajadores no deja de ser una relación contractual sujeta a los derechos y obligaciones de carácter tuitivo por parte de éste. Esta tesis descansa en el desarrollo del modelo social y democrático de los estados.

Parte de la doctrina, entre ellos Miranda (2004) explica que el vínculo entre la administración y el empleado no es el resultado de un proceso unilateral, sino contractual. Entre las partes existe un estado de coordinación, puesto que hay acuerdo de voluntad sobre un mismo objeto jurídico. Se lo considera contrato de derecho público porque uno de los sujetos de la relación es el titular de "intereses generales". Finalmente, se concibe al empleo público como una relación jurídica originada por un acto bilateral, es decir, por una concurrencia de voluntades para su formación, realización y extinción. (p. 5)

Uno de los importantes pensadores que defiende la tesis contractualista es Bielsa (1956), que considera que la relación jurídica que existe entre los empleados y la Nación es contractual, pues tiene todos los caracteres de un contrato. Será un contrato especial por la forma de manifestarse el consentimiento; será de "adhesión", pues el empleado se adhiere a las condiciones establecidas "unilateralmente" por la administración pública; pero eso no niega a aquélla el carácter de contrato. La única diferencia existente entre estos contratos y los de derecho común es que los primeros son públicos por su objeto (función pública), su finalidad (servicio e interés público) y el carácter que la administración inviste al formarlos (persona de derecho público). Pero por todo ello, precisamente, se trata de un contrato de derecho público. (p. 77)

En el caso peruano, Balbín Torres (2005:4), en una investigación respecto a la naturaleza del empleo público sostiene que el modelo social y democrático del Estado determina la superación absoluta del unilateralismo, como técnica de gobierno de las relaciones laborales en la organización administrativa por los basados en la gama de valores y principios previstos en el Derecho Laboral. Para este investigador de la 
Universidad Católica, la esencia del contrato laboral no se desvirtúa con la imposición del interés público, la que sólo adicionará algunas particularidades, de allí que plantea la plena funcionalidad del Derecho de la Negociación Colectiva en la relación del empleo público.

Lo expuesto es de especial importancia y, en el caso de la Constitución Política, nos permite interpretar respecto del Capítulo IV: De la función pública con el Capítulo II: De los derechos sociales y económicos, que regula los derechos laborales; normas constitucionales que determinan el marco de la regulación del derecho del empleo público. Se propone la existencia de un derecho del empleo público cuyos principios y normas estén orientados a contar con personal eficiente y profesional que garantice la adecuada prestación de los servicios públicos, pero en cuyo contenido se respeten y promuevan los derechos fundamentales y derechos laborales reconocidos en la Constitución y los tratados sobre derechos humanos, especialmente los de la Organización Internacional del Trabajo - OIT.

\subsection{Antecedentes sobre el régimen laboral del empleo público}

\subsubsection{Aspectos históricos}

Para poder entender la problemática del empleo público, debemos observar los cambios más importantes relacionados a la presente investigación, en tal virtud se tiene lo expuesto por la Comisión de Trabajo y Seguridad Social ${ }^{3}$ :

- La Administración Pública en nuestro país tuvo sus bases en la administración colonial. Así, en 1821 José de San Martín promulga el Estatuto Provisional, mediante el cual se dispuso que se mantuviera la legislación colonial. El antecedente más importante en el tema vino años después, cuando el Mariscal Ramón Castilla en su primer gobierno (1845-1851) aprueba el primer Presupuesto de la República, promulga el Código Civil, la Ley de Organización Interior, la Ley de Ministerios que reconoce los derechos de los empleados públicos y aprueba la Ley de Cesantía.

\footnotetext{
${ }^{3}$ Informe elaborado en el año 2005 por la Comisión de Trabajo y Seguridad Social del Congreso de la República, el mismo muestra el avance de la historia de la reforma del Empleo Público en el Perú, la misma que comparto en virtud a los acontecimientos históricos importantes a lo largo de los años.
} 
- La primera norma que trata integralmente la carrera administrativa fue con la Ley $\mathrm{N}^{\circ} 11377$ - Estatuto y Escalafón del Servicio Civil, que fue dictada en 1950 por el General Manuel Odría. Esta norma “[...] establece los derechos y deberes de los empleados públicos, reconociendo la carrera administrativa, escalafón y clasificación periódica, igual oportunidad para hombres y las mujeres, el ingreso por concurso para el personal de carrera, ascenso por concurso y basándose en la foja de servicio. Así, la norma señalada crea la carrera administrativa, establece el escalafón y constituye el Consejo Nacional del Servicio Civil y se define cuatro clases de empleados: de carrera, por contrata, adscritos y personal del servicio interno.

- En el año 1958 se crea el Instituto Peruano de Administración Pública con el fin de capacitar a los servidores públicos y en 1964 se conforma la Oficina de Racionalización y Capacitación de la Administración Pública.

- En el año 1973, el gobierno del General Velasco emite el D.L. N²0316, por medio del cual crea el Instituto Nacional de la Administración Pública, como entidad rectora de la administración pública, que se hace cargo de la ESAP.

- En el año 1984, el gobierno de Fernando Belaúnde Terry dictó el Decreto Legislativo 276, Ley de Bases de la Carrera Administrativa y de Remuneraciones del sector público. Esta norma recoge los principios y modelos establecidos en el D.L. $\mathrm{N}^{\circ} 11377$ y pone énfasis en los derechos de los servidores públicos y se establece que las remuneraciones se fijan desde el nivel central, vale decir desde la aprobación del presupuesto desde el Gobierno.

- Conforme a las reformas expuestas el D.L. №11377 y el D.L. № 276 no fueron suficientemente eficaces, toda vez que ambas normas no han contado con estímulos para la proyección de la carrera pública de los trabajadores, no hubo promoción de mérito y capacidad del personal. De conformidad al informe mencionado, el problema de estas propuestas fue la rigidez normativa, toda vez que no permitió la explotación de la carrera administrativa y la eficiencia del servicio a los ciudadanos, esto se evidencia en la burocracia, la pérdida de compromiso y de la vocación del servicio.

- El año 2013, existen actualmente hasta cuatro regímenes que se encuentran incursos dentro del supuesto del régimen del Trabajador del Sector Público, existen los trabajadores de la Actividad Privada (D.L. 728), los que pertenecen a la Carrera 
Administrativa (D.L. 276), los que realizan Contratos Administrativo de Servicios CAS (D.L. 1057), trabajadores que pertenecen a Carreras Especiales, y quienes se encuentran bajo servicios no personales - recibos por honorarios quienes prestan servicios de naturaleza civil.

- Para el año 2014 se Publicó la Ley del Servicio Civil originando el cambio más importante relacionado a la administración pública. Un año después aproximadamente se publicaron tres reglamentos relacionados a su aplicación.

- Al respecto debemos comentar que el avance respecto a las reformas del sector público relacionado a lo trabajadores no fue la más feliz, sin embargo se han evidenciado grandes cambios en busca de la eficiencia para un mejor servicio al ciudadano.

\subsubsection{Antecedentes bibliográficos nacionales e Internacionales}

\subsubsection{Trabajos previos nacionales}

Entre los más importantes trabajos de investigación nacionales consultados podemos mencionar a:

i).- "Problemática de la existencia de distintos regímenes de contratación de personal en el Estado" 2013, Tesis para optar el grado de maestro de la graduando Luisa Pamela Beltrán Larco, de la Escuela de Postgrado de la Pontificia Universidad Católica del Perú.

La investigación trata de demostrar la existencia de una deficiente regulación en la contratación pública de personal en Perú, haciendo un análisis de las distintas Normas de Contratación del Sector Público, tales como son el Decreto Legislativo 276 - Ley de Bases de la Carrera Administrativa y de Remuneraciones del Sector Público, la Ley 28175 - Ley Marco del Empleo Público (LMEP) y el Decreto Legislativo 1057 denominado "Régimen Especial de Contratación Administrativa de Servicios.

El estudio tiene como una de sus conclusiones que en la última década diferentes instituciones públicas vinieron contratando personal bajo la modalidad de Servicios No Personales (quienes pasaron al régimen del Contrato Administrativo de Servicios - CAS) sin limitación alguna, dejando de lado lo establecido por las normas 
de acceso a la Administración Pública y vulnerando con ello derechos laborales de los servidores públicos.

\section{ii).- "Particularidades de la Negociación Colectiva en el Sector Público" 2015. Este artículo corresponde a Oxal Avalos Jara,}

En dicha investigación se sustenta que el derecho a la negociación colectiva es un derecho de orden fundamental que debe ser fomentado como un mecanismo de solución pacífica de los conflictos laborales. Y si bien en sentido amplio puede expresarse en la fijación de las condiciones de trabajo y empleo, en la regulación de las relaciones entre empleadores y trabajadores, y en la regulación de las relaciones entre empleadores o sus organizaciones y una organización o varias organizaciones de trabajadores, o lograr todos estos fines a la vez no es menos cierto que no se trata de un derecho de carácter absoluto, sino que por el contrario, se encuentra limitado, no solo por su propio contenido, sino por su relación con otros bienes constitucionales.

iii).- "Unilateralismo y Negociación Colectiva" del Fondo Editorial de la Pontificia Universidad Católica del Perú (2005), cuya autoría corresponde al profesor Edgardo Balbín Torres.

Esta obra realiza un análisis teórico y práctico de la teoría estatutaria, que él denomina unilateralista para explicar el rol hegemónico del Estado en su relación con el servidor público. El encuentra una relación entre la teoría unilateralista y la negociación colectiva con serias restricciones que se aplica en el Perú.

\subsubsection{Trabajos previos internacionales}

Entre los más importantes investigaciones nacionales consultadas podemos mencionar:

i).- "Organización y negociación colectiva de los trabajadores del sector público en América Latina: normas y prácticas sindicales" 2014, de los investigadores Alvaro Orsatti y Camilo Rubiano. 
Ellos realizan una investigación de tipo comparativo respecto al desarrollo de la negociación colectiva en la administración pública entre los países de la región, entre ellos, Perú, Panamá, Argentina, Chile, Ecuador, entre otros. ${ }^{4}$

\section{ii).- "La Negociacion Colectiva en el Sector Público" Dr. José Manuel López}

Gómez Profesor Asociado, Director de Recursos Humanos Universidad de Sevilla.

Este estudio tiene como objetivo dar a conocer el análisis de las diferentes tesis sobre el posible reconocimiento constitucional del derecho de negociación colectiva de los empleados públicos en España, los límites derivados de los principios que rigen la actuación administrativa que se imponen a ese derecho, deteniéndonos en especial en el estudio de la constitucionalidad de la imposición de límites a la negociación colectiva de las retribuciones o la posible reducción de retribuciones pactadas previamente por circunstancias económicas sobrevenidas, los principios que rigen la negociación colectiva de los empleados públicos, su estructura, su contenido, la naturaleza jurídica de los pactos, acuerdos funcionariales e instrumentos de negociación conjunta y el procedimiento negocial.

\footnotetext{
4 (http://www.ctmargentina.org/pdfs/3-Organizacionynegociacioncolectiva-sectorpublicoAL.pdf consultado el 9 de abril de 2016)
} 


\section{CAPÍTULO 3: LA NECESIDAD DE ORDENAR EL SISTEMA NACIONAL DE RECURSOS HUMANOS}

\subsection{Situación poblacional}

La Autoridad Nacional del Servicio Civil, emitió en el Año 2013 un Informe ${ }^{5}$ a la Comisión de Trabajo del Congreso de la República del Perú, relacionado a la situación actual de los trabajadores del Sector Público, los mismos que evidenció los siguientes resultados:

Figura 3.1

Los Servidores Civiles según su régimen laboral

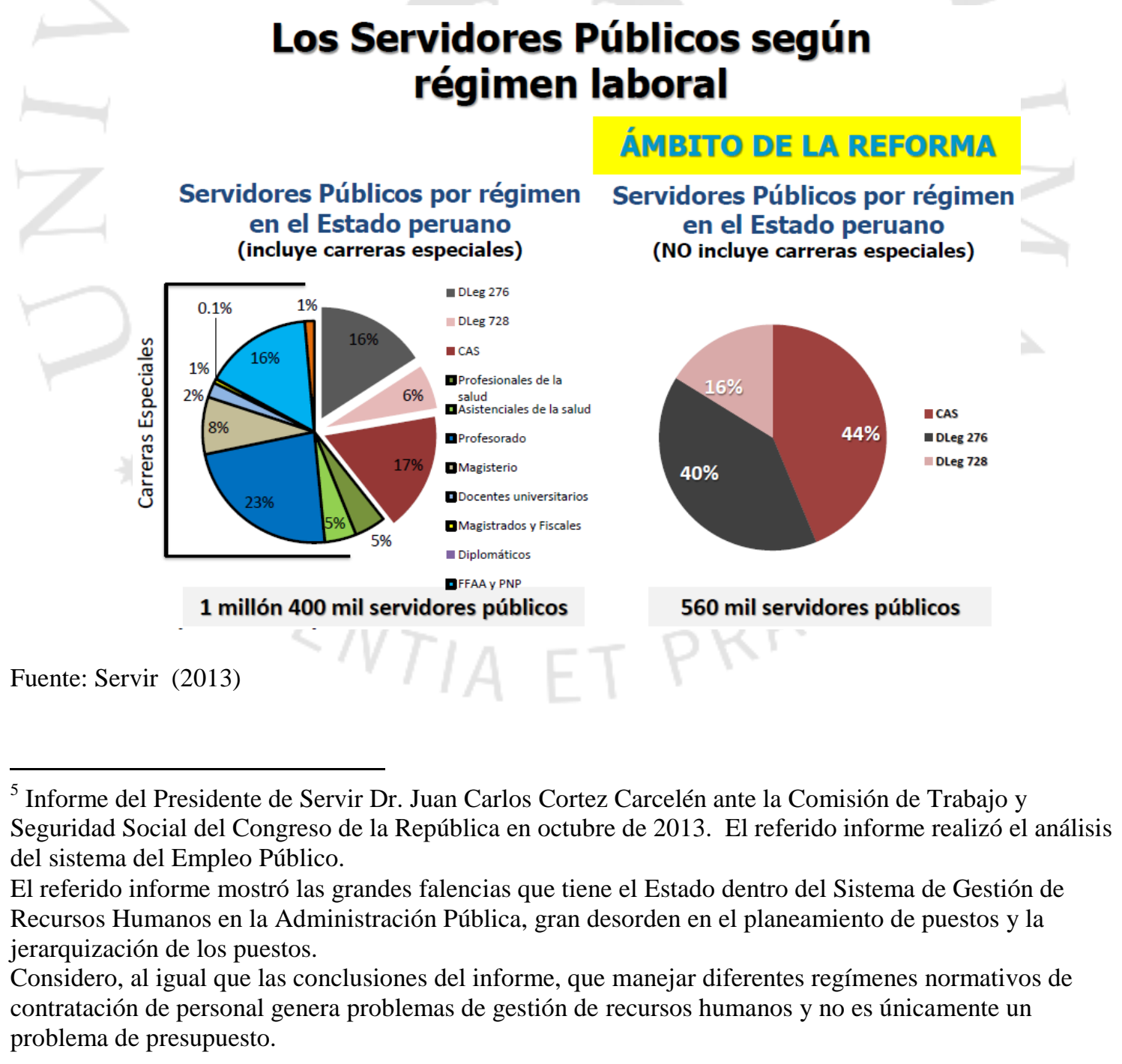


Al 2013 coexisten alrededor de Un Millón Cuatrocientos Mil (1 400 000) Servidores Públicos los mismos que se distribuyen en el Régimen de Contratación Administrativa de Servicios - CAS (DL 1057), Régimen Laboral del a Actividad Privada (D.L N ${ }^{\circ}$ 728), Ley de la Carrera Administrativa (DL 276) y 8 Carreras especiales.

Esto genera que exista una coexistencia de los regímenes normativos en razón a la gran masa de trabajadores, en los diferentes rangos de jerarquía, desde los más comunes, hasta los puestos relacionados a la gestión de cada entidad.

Al tener una gran variedad de regímenes de contratación, predomina un gran desorden normativo en la administración y asignación de los beneficios sociales de los servidores públicos. Para poder explicar este tema podemos analizar el siguiente ejemplo, para el caso del pago de las gratificaciones, al personal que fue contratado bajo el régimen del D. Legislativo 728 le corresponde dos remuneraciones en julio y diciembre, mientras quienes pertenecen al régimen del D. Legislativo 276 y al D. Legislativo 1057 le corresponde el pago de dos aguinaldos que previamente hayan sido aprobados por el Ministerio de Economía.

Sin perjuicio de lo expuesto, se debe tener presente las restricciones presupuestarias impuestas por el Estado para la contratación y nombramiento de personal para puestos de naturaleza permanente ha generado un abuso al uso desmedido de la modalidad de la Contratación Administrativa de Servicios CAS.

Esto significa que el área de recursos humanos de cada entidad tiene el problema en la liquidación de beneficios sociales de sus trabajadores en todas sus versiones, al existir diferentes regímenes normativos no se puede aplicar una uniformidad coherente a una sola modalidad.

\subsection{Pluralidad de regímenes}

Al existir la pluralidad de regímenes en cada entidad, no puede darse una uniformidad en razón a los criterios para definir que tipo de puesto corresponde contratar personal bajo el régimen privado o bajo el régimen de los Contrato Administrativo de Servicios, lo que genera problemas en razón a la aplicación de criterios.

De conformidad a los datos de SERVIR, los grupos en los que se evidencia mayor cantidad de personal contratado en las Entidades Públicas son los que fueron 
contratados bajo el régimen Laboral Público (D.Legislativo 276) régimen laboral privado (D.L. 728) y del Régimen de la Contratación Administrativa de Servicios (D.Legislativo 1057) de conformidad con la siguiente tabla:

Tabla 3.1.:

Comparativo Población

\begin{tabular}{lcc}
$\begin{array}{l}\text { Regímenes } \\
\text { Laborales }\end{array}$ & $\begin{array}{l}\text { Población } \\
\text { Estimada }\end{array}$ & Porcentaje \\
\hline D.L. 276 & 224000 & $16 \%$ \\
\hline D.L. 728 & 84000 & $6 \%$ \\
\hline D.L. 1057 & 238000 & $17 \%$ \\
\hline Carreras Especiales & 854000 & $61 \%$ \\
\hline Total estimado & 1400000 & $100 \%$
\end{tabular}

Fuente: Realizado sobre informe SERVIR-2013

\subsection{Caos Normativo e Inconsistencia de la Carrera Administrativa}

Como ya se explicó en el capítulo anterior durante varios gobiernos siempre se ha observado restricciones presupuestarias relacionadas a la contratación de personal dentro del Estado que son de naturaleza permanente, lo cual ha generado problemas en las tablas de asignación de puestos. Esto ha generado problemas en uso desmedido de abuso de figuras jurídicas de contratación de personal, sea bajo la modalidad de servicios no personales y el Contrato Administrativo de Servicios - CAS.

Considerando el contrato de trabajo que tenga el trabajador del sector público, se va a evidenciar diferentes conceptos remunerativos en razón a su tipo de contratación, con lo cual se hace cada vez más complejo el sistema.

Se debe tener presente que, a pesar de manejar un sistema bien austero relacionado a presupuesto, se observan nuevas contrataciones cada año, los mismos que se estiman en 40 mil personas que ingresan a trabajar al sector público anualmente. Lo expuesto se puede evidenciar en el siguiente tabla, de conformidad a los datos de INEI ${ }^{6}$ :

\footnotetext{
${ }^{6}$ De conformidad a los datos de INEI y SERVIR la evaluación de ingreso de personal del año 2004 a
} 
Figura: 3.2 .

Evolución del número de servidores públicos por año (en miles)

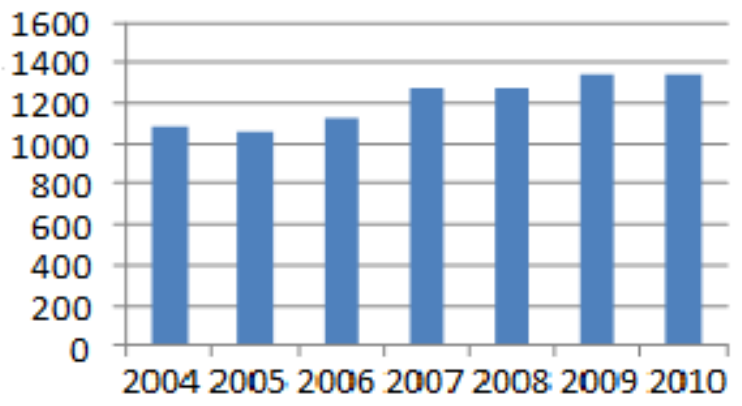

Fuente Servir 2013

\subsection{La Ley del servicio Civil - Marco Normativo.}

El 4 de julio de 2013 se publicó en el Diario Oficial El Peruano la Ley 30057, Ley del Servicio Civil, que, de conformidad al artículo Primero del Título Preliminar, tiene por objeto establecer el régimen único y exclusivo para las personas que prestan servicios en las entidades públicas del Estado, así como para aquellas personas encargadas de su gestión, del ejercicio de sus potestades y de la prestación de los servicios en cada uno de éstas.

La norma tiene por finalidad establecer mayores nieles de eficacia y eficiencia en el Servicio Civil, así como promover el desarrollo de las personas que lo integran.

La existencia de una reforma en la Administración Pública en materia de Servicio Civil es necesaria porque el Estado debe cambiar y establecer mecanismos para responder a las nuevas exigencias del mundo contemporáneo y buscar la excelencia en el servicio y dar mejores oportunidades de forma interna.

2010 se evidencia un ingreso promedio de 40 mil personas conforme a lo siguiente (en miles):

Año 2004: 1081

Año 2005: 1056

Año 2006: 1124

Año 2007: 1268

Año 2008: 1274

Año 2009: 1344

Año 2010: 1345 
Se dan nuevos criterios de contratación y se ofrece estabilidad laboral en razón a un sistema de oportunidades mejor al de todos los regímenes, esto realmente otorga un real beneficio a los servidores en la administración pública.

De igual manera, el 13 de junio de 2014, se ha publicado los tres reglamentos de la Ley de Servicio Civil:

- $\quad$ El Decreto Supremo $N^{\circ}$ 040-2014-PCM Reglamento General de la Ley 30057

- $\quad$ El Decreto Supremo N $^{\circ}$ 041-2014-PCM Reglamento del Régimen Especial para Gobiernos Regionales

- $\quad$ El Decreto Supremo Nº138-2014-PCM Reglamento de Compensaciones de la Ley 30057

Las consecuencias inmediatas que busca la Ley de Servicio Civil y sus normas reglamentarias es el traslado del personal de las diferentes modalidades de contratación a un único sistema.

De acuerdo a las normas citadas al pasar al personal al Régimen del Servicio Civil se logrará lo siguiente:

1. Estabilidad Laboral: la estabilidad de los Contratos del Servidor Civil será de carácter permanente, lo cual evidenciará mejoras al personal que es contratado bajo el régimen del Contrato Administrativo de Servicios. Antes de esta modificatoria, los trabajadores contratados bajo esta modalidad tenían que suscribir contratos de naturaleza temporal.

2. Reconocimiento de beneficios sociales: este nuevo régimen busca otorgar a quienes se pasen a este nuevo sistema beneficios sociales equiparables a los contratos laborales de la actividad privada, por ejemplo 30 días de vacaciones, gratificaciones completas, depósito de CTS, entre otros.

3. Capacitación permanente, se otorga capacitación permanente en razón al sistema de políticas de promoción y escala remunerativa, las mismas que estarán sujetas a evaluación.

4. Se propone una carrera administrativa en un solo grupo ocupacional y se aplica una mejora en la evaluación del desempeño. 
La norma no exige que todos deban pasar al nuevo régimen. Es decir que no se debe realizar más contrataciones bajo la modalidad del CAS y de la carrera Pública Administrativa y del Régimen de la Actividad Privada. Por lo expuesto, el ingreso al nuevo régimen es optativo y los que no ingresan al nuevo régimen seguirán manteniendo su régimen laboral.

\subsection{Análisis de los derechos laborales de los Servidores Civiles.}

\subsubsection{Comparación con otros regímenes laborales existentes}

Como se evidencia, existen varios conceptos que son beneficiosos para los trabajadores que opten por cambiarse al nuevo régimen de servicio civil, las mismas que se reflejan en lo siguiente:

1. Estabilidad laboral: ya no existirán problemas para quienes hayan tenido contratos temporales, actualmente de podrá tener un contrato a plazo indeterminado (CAS).

2. Capacitación Permanente: el Sistema del Servicio Civil permitirá poder capacitar al personal logrando la eficiencia del servicio la mejora curricular de los puestos.

3. Reconocimiento de derechos laborales: la Ley del Servicio Civil permitirá a quienes postulen en ella poder obtener mejores beneficios laborales que en otros regímenes.

4. Se contempla la figura de indemnización por despido arbitrario de una remuneración y media por año, la misma que mejorará a quienes hayan pertenecido a regímenes laborales diferentes al D. Legislativo 728, Ley de Fomento del Empleo. .

5. Evidencia de carrera pública: con el Sistema de Servicio Civil se ha programado concursos progresivos en todas las entidades, por lo que podrán postular a nuevos puestos a nivel transversal en todas las entidades.

La Tabla 3.2. nos permite comparar con los otros regímenes normativos de contratación: 
Tabla 3.2:

Comparación de Derechos Individuales entre los Diferentes Regímenes Laborales y el Servicio Civil

\begin{tabular}{|c|c|c|c|c|}
\hline CONCEPTOS & $\begin{array}{c}\text { RÉGIMEN } \\
\text { LABORAL COMÚN } \\
\text { D. LEGISLATIVO } \\
728\end{array}$ & $\begin{array}{l}\text { RÉGIMEN LABORAL } \\
\text { PÚBLICO } \\
\text { D.Leg. } 276\end{array}$ & $\begin{array}{l}\text { D. LEGISLATIVO } \\
1057 \\
\text { (CAS)MODIFICADO } \\
\text { POR LA LEY } 29849\end{array}$ & Ley 30057 \\
\hline $\begin{array}{l}\text { Gratificaciones } \\
\text { o } \\
\text { Aguinaldos }\end{array}$ & $\begin{array}{l}\text { Dos gratificaciones: } \\
\text { remuneración mensual } \\
\text { en julio y diciembre }\end{array}$ & $\begin{array}{l}\text { Dos aguinaldos aprobados } \\
\text { por el MEF } \\
(\mathrm{El} 2012 \text { fue de } \mathrm{S} / \text {. } \\
300.00)\end{array}$ & $\begin{array}{l}\text { Dos aguinaldos } \\
\text { aprobados por el MEF } \\
\text { (Si hay presupuesto) }\end{array}$ & $\begin{array}{l}\text { Dos aguinaldos de } \\
\text { una remuneración } \\
\text { mensual en julio y } \\
\text { diciembre } \\
\text { (Art. 31.2) }\end{array}$ \\
\hline $\begin{array}{l}\text { Descanso } \\
\text { Vacacional }\end{array}$ & 30 días $\mathrm{x}$ año & 30 das $\mathrm{x}$ año & 30 días $\mathrm{x}$ año & $\begin{array}{l}30 \text { días } x \text { año } \\
\text { (Art. 31.2) }\end{array}$ \\
\hline $\begin{array}{l}\text { Licencias } \\
\text { pagadas }\end{array}$ & $\begin{array}{l}\text { Maternidad, paternidad } \\
\text { y otros }\end{array}$ & $\begin{array}{l}\text { Maternidad, paternidad y } \\
\text { otros }\end{array}$ & $\begin{array}{l}\text { Maternidad, paternidad } \\
\text { y otros }\end{array}$ & $\begin{array}{l}\text { Maternidad, } \\
\text { paternidad y otros } \\
\text { /Art. 47) }\end{array}$ \\
\hline CTS & $\begin{array}{l}\text { Una remuneración } \\
\text { mensual x año sin tope } \\
\text { A depositarse en } \\
\text { entidades financieras }\end{array}$ & $\begin{array}{l}\text { Media remuneración } \\
\text { mensual principal (R.P.) } \\
\text { por los primeros } 20 \text { años y } \\
\text { completa por los } \\
\text { siguientes años. (La R.P. } \\
\text { no considera todos los } \\
\text { ingresos). }\end{array}$ & No contempla & $\begin{array}{l}\text { Una remuneración } \\
\text { promedio mensual de } \\
\text { los últimos } 36 \text { meses. } \\
\text { (Art. 33) } \\
\text { Depósito entidades } \\
\text { financieras Ley } \mathrm{N}^{\circ} \\
30408\end{array}$ \\
\hline $\begin{array}{l}\text { Indemnización } \\
\text { por Despido } \\
\text { Injustificado }\end{array}$ & \begin{tabular}{llr} 
Una y & media \\
remuneración & \multicolumn{2}{c}{ mensual } \\
por cada año de & añ dervicios
\end{tabular} & No contempla & $\begin{array}{l}\text { Remuneraciones dejadas } \\
\text { de percibir, Hasta tres } \\
\text { retribuciones mensuales }\end{array}$ & $\begin{array}{l}\text { Se contempla } \\
\text { Indemnización cuyo } \\
\text { monto lo establecerá } \\
\text { el reglamento.(Art. } \\
\text { 36) Reglamento Art. } \\
\mathbf{2 2 7} \\
1 \quad 1 / 2 \text { RM por c/a } \\
\text { servicios }\end{array}$ \\
\hline $\begin{array}{l}\text { Prescripción } \\
\text { laboral }\end{array}$ & $\begin{array}{l}\text { Cuatro años después del } \\
\text { cese }\end{array}$ & $\begin{array}{l}\text { No contempla (Se aplica } \\
\text { CC) }\end{array}$ & No contempla & $\begin{array}{l}\text { Cuatro años después } \\
\text { del cese ( Art. 37) }\end{array}$ \\
\hline $\begin{array}{l}\text { Concurso } \\
\text { público }\end{array}$ & No contempla & $\begin{array}{l}\text { Concurso público, } \\
\text { (Ganadores exonerado del } \\
\text { periodo de prueba }\end{array}$ & Concurso público & $\begin{array}{l}\text { (Ganadores } r \text { no } \\
\text { exonerados de } \\
\text { periodo de prueba). } \\
\text { Se exceptúan s } \\
\text { servidores 276, 729 y } \\
\text { CAS (Art. 72 y 3ra } \\
\text { DCT) }\end{array}$ \\
\hline $\begin{array}{l}\text { Libertad } \\
\text { sindical }\end{array}$ & $\begin{array}{l}\text { Si de acuerdo a la Ley } \\
\text { de } \\
\text { Colectivas de Trabajo }\end{array}$ & $\begin{array}{l}\text { Si de acuerdo al Convenio } \\
151 \text { de la OIT }\end{array}$ & Si de acuerdo a la LRCT & $\begin{array}{l}\text { Si de acuerdo al } \\
\text { Convenio } 151 \text { de la } \\
\text { OIT }\end{array}$ \\
\hline
\end{tabular}


Negociación Colectiva
Si de acuerdo a la LRCT Negociación restringida

(No permite negociar puntos económicos) colectiva No contempla

(pero debe considerarse que forma parte de la libertad sindical)
Negociación colectiva restringida. De acuerdo al Convenio 151 OIT.

(No permite negociar puntos económicos)

(Art. 42,43 y 44).

Declarados inconstitucionales por el TC.

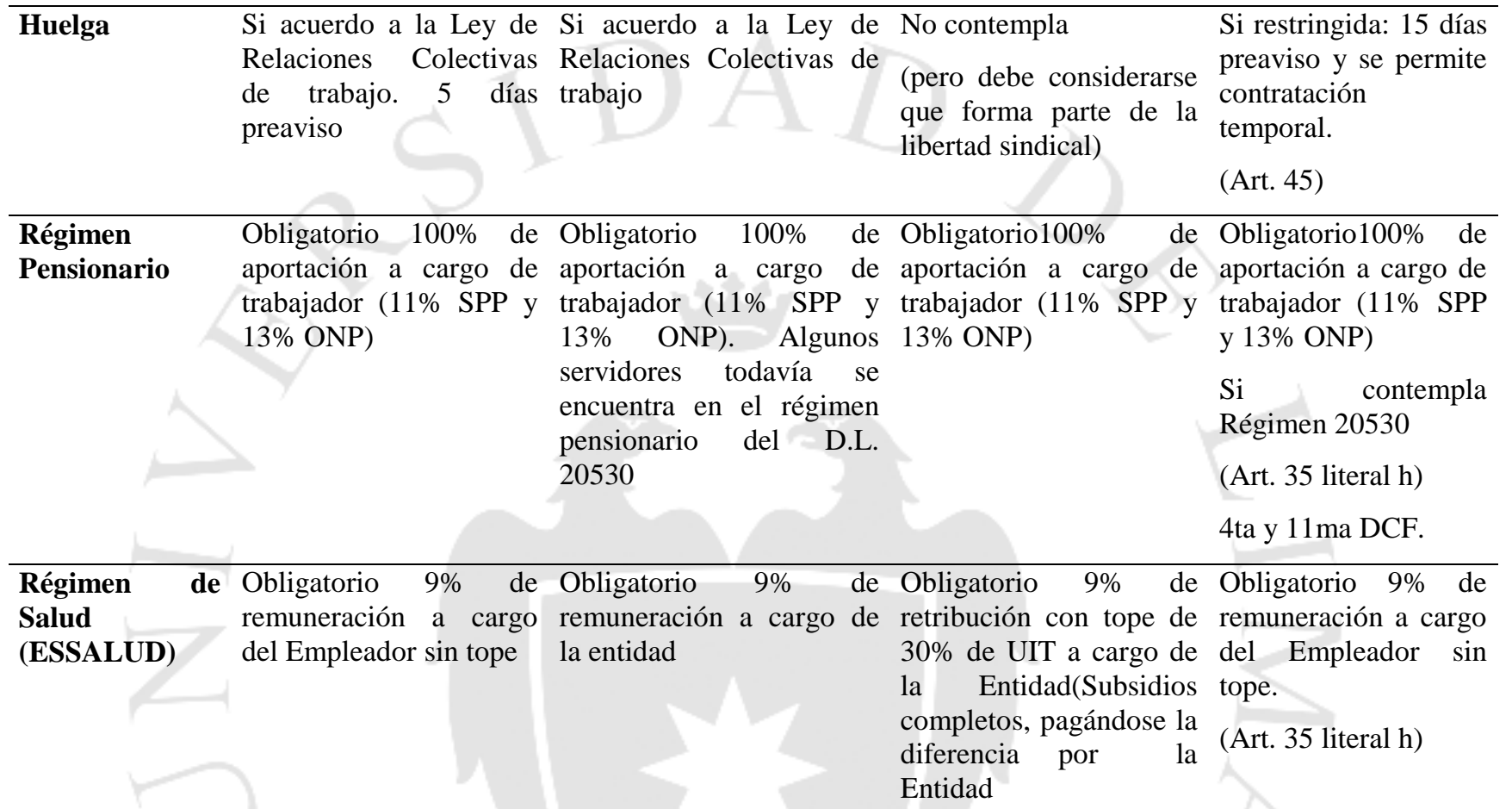

Fuente: Normas relativas a los diferentes regímenes laborales

Los datos en el cuadro analizado, son de conformidad a las fuentes normativas vigentes a la fecha, a través del cual se evidencia las principales diferencias entre todos los regímenes de contratación, asimismo evidencia en que supuestos se ve las mejoras en razón a quienes opten por el cambio de régimen.

Podemos concluir que, de los tres regímenes generales que corresponde al ámbito de la reforma de la Ley del Servicio Civil se evidencia mejoras en los regímenes del Decreto Legislativo 276 y del régimen de los Contratos Administrativos de Servicios CAS. En cambio en lo que respecta al régimen laboral privado, regulado por el Decreto Legislativo 728 no se observa ventaja normativa alguna. Asimismo: 
- En el régimen del Decreto Legislativo 276, los Servidores se beneficiarán porque se "sinceraran" sus remuneraciones, incrementándose notoriamente sus diminutas remuneraciones básicas.

- Su compensación por tiempo de servicio se incrementará notoriamente en razón al incremento de sus básicos y porque ésta se calculará sobre la base de una remuneración promedio de los tres últimos años. En consecuencia se eliminará formula aún vigente, que corresponde a sólo quince días de remuneración básica por los primeros veinte años, y remuneración básica completo por la diferencia.

- Se podrá reactivar la carrera administrativa, que en estos momentos, en la práctica, no se aplica en las entidades públicas.

Con respecto a los servidores públicos contratados bajo la modalidad del CAS, éstos serán beneficiados por las siguientes razones:

- Pasarán de una relación laboral de carácter temporal y transitorio, a una de carácter permanente con las entidades públicas.

- Le corresponderá el derecho de compensación por tiempo de servicio, a razón de una remuneración promedio mensual de los últimos tres años.

- Con respecto a los aguinaldos de los meses de Julio y diciembre, ya que corresponderán a una remuneración mensual, superando a lo que se entrega en la actualidad, que son montos mínimos establecidos por el Ministerio de Economía y Finanzas.

Con respecto a los servidores contratados bajo el régimen privado, podemos concluir que éstos serian los más afectados a determinados beneficios, como son:

- La compensación por tiempo de servicios será menor ya que no calculará con la última remuneración vigente, sino que será calculada sobre el promedio de las remuneraciones de los últimos tres años.

- La Ley 30057 también establecía desventajas para el tema de negociación sobre incrementos remunerativos, eliminando la posibilidad de negociación salarial, situación que fue enmendada por el Tribunal Constitucional al expulsarla del sistema jurídico a través de sus sentencia recaída en el expediente $\mathrm{N}^{\circ}$ 00003-2013-PI/TC y otras respecto a la inconstitucionalidad 
del artículo 6 de la Ley de Presupuesto y Cuenta General de la República Ley 29812.

Finalmente, con relación a la disposición de la Ley de Servir que establecía que la compensación por tiempo de servicio de los trabajadores del régimen privado y del régimen del servicio civil solamente debían ser entregados a los servidores públicos al momento del cese. Ello ha sido subsanado por la Ley 30408 que modifica el artículo del Texto Único Ordenado del Decreto Legislativo 650 - Ley de CTS, estableciendo la obligatoriedad de las entidades públicas a realizar los depósitos en la cuenta de las entidades financieras designadas por los servidores. 


\section{CAPÍTULO 4: EL DERECHO A LA NEGOCIACIÓN COLECTIVA EN EL RÉGIMEN COMÚN Y EN RÉGIMEN DEL SERVICIO CIVIL}

\subsection{La Negociación Colectiva: Aspectos Generales}

Antes de poder ingresar al análisis de lo estipulado en la Ley de Servicio Civil debemos tener presente que debemos entender por Negociación Colectiva.

La Negociación Colectiva es un instrumento que sirve como un medio para que empleadores y trabajadores resuelvan sus conflictos de intereses. Es el conjunto de relaciones y procesos de acercamiento y diálogo en cuyo seno la autonomía colectiva de trabajadores y empleadores produce el convenio colectivo. La negociación colectiva es de por sí, un proceso normativo que expresa una relación entre organizaciones.

Este proceso consta de tres elementos culminantes: la: determinación de las unidades negociadoras, la delimitación del objeto de la negociación y la obligación de negociar de buena fe.

Para la Organización Internacional del Trabajo - OIT, a través del Convenio 154 señala que la negociación colectiva "constituye todas las negociaciones que tienen lugar entre un empleador, un grupo de empleadores o una organización o varias organizaciones de empleadores por una parte, y una organización o varias organizaciones de trabajadores, por otra, con el fin de:

a) Fijar las condiciones de trabajo y empleo, o

b) Regular las relaciones entre empleadores y trabajadores, o

c) Regular las relaciones entre empleadores o sus organizaciones una organización o varias organizaciones de trabajadores, o lograr todos estos fines a la vez."

El Texto Único Ordenado de la Ley de Relaciones Colectivas del Trabajo conceptúa a la convención colectiva como el acuerdo destinado a regular las remuneraciones, las condiciones de trabajo y la productividad, y demás, concernientes a las relaciones entre 
trabajadores y empleadores. Estas se celebran, de una parte, o varias organizaciones sindicales de trabajadores por, en ausencia de éstas, por representantes de los trabajadores interesados, expresamente elegidos y autorizados; y de la otra, por un empleador, un grupo de empleadores, o varias organizaciones de empleadores.

Conforme a Villavicencio (2010) la Negociación Colectiva es:

Un proceso de creación de normas que expresa una relación de poder entre organizaciones, un uso diplomático de poder en el que se evidencia su naturaleza de institución política que transforma el conflicto en consenso a través de un complejo procedimiento institutivo de normas, montado sobre las relaciones de 'poder de las organizaciones, sindical y patronal.

La Negociación Colectiva da como resultado la suscripción por ambas partes del Convenio Colectivo que no es otra cosa que la manifestación expresa de voluntad de las partes intervinientes en la negociación y la Autoridad Administrativa de Trabajo.

De conformidad a lo señalado por Toyama (2010) el Convenio Colectivo debería contener, bajo las recomendaciones hechas por la Organización Internacional del Trabajo, una lista abierta de puntos relacionados a la negociación, con el fin de:

(i) Fijar condiciones de trabajo y empleo

(ii) Regular las relaciones entre empleadores y trabajadores.

(iii) Regular las relaciones entre empleadores o sus organizaciones y una organización o varias organizaciones de trabajadores, o lograr todos estos fines a la vez.

Estos son los principales problemas que deben apuntar para resolver todos los convenios colectivos en razón de generar paz social y una relación correcta para garantizar la estimulación de la convivencia social en el centro de trabajo.

\subsubsection{Principios}

Los principios del Derecho Colectivo que se aplican también al sindicalismo, por ser la institución más importante de este derecho, son los siguientes:

\section{- Principio de libertad de asociación o libertad sindical}


Consiste en el derecho que tienen los trabajadores a afiliarse, a no afiliarse o a desafiliarse de las organizaciones sindicales. La Constitución de 1993 recoge este principio en su Artículo $28^{\circ}$, inciso 1 que establece:

"El Estado reconoce los derechos de sindicación, negociación colectiva y huelga. Cautela su ejercicio democrático: 1. Garantiza la libertad sindical.”

En tal sentido, la promoción de la libertad sindical por parte del Estado, impuesta por nuestro texto constitucional, resulta fundamental, puesto que la idoneidad del fenómeno sindical para equilibrar las desiguales relaciones existentes en el mundo del trabajo..

El principio de la libertad sindical se vincula con el Convenio $N^{\circ} 87$ de la OIT, al establecer que el derecho tanto de trabajadores como de empleadores a constituir organizaciones que estimen conveniente, sin organización previa.

Bueno Magano (1993) lo define como el derecho de los trabajadores y empleadores a no sufrir la interferencia de los poderes públicos, ni de otros elementos, en el proceso de su organización, como en lo relativo a la promoción de intereses propios o de los grupos a que pertenecen.

\section{- Principio de la autonomía colectiva}

La libertad sindical, considerado en el Convenio $\mathrm{N}^{\circ} 87$ de la OIT, se refiere a que la constitución, existencia y aún la extinción del sindicato no puede depender de extraños sino sólo de la voluntad de sus propios componentes.

Martínez Vivot (1996:444), mencionando a Ermida Uriarte, dice que no sólo es aquel principio de poder constituir libremente el sindicato, sino también el de fijar sus estatutos, regular su funcionamiento sin intervenciones o restricciones y no quedar sujeto a una disposición estatal que determine su extinción. (p. 444)

Algunos especialistas le dan al principio de autonomía colectiva una connotación más general, manifestando que esta no sólo alcanza al campo de los trabajadores y sus organizaciones sino también al campo de los empleadores y sus organizaciones para que puedan tomar sus propias decisiones y regular autónomamente sus intereses contrapuestos a través de la negociación colectiva. Así, el profesor Villavicencio Ríos (2004, p. 48) expresa que así como el Estado se 
reserva para si la facultad de regular el interés público, a través de normas imperativas de orden público e irrenunciables, y así como se reconoce a los individuos la facultad de autorregular sus intereses estrictamente privados dentro del marco legal correspondiente, a través de la autonomía de la voluntad, también se reconoce la autonomía de los grupos intermedios de regular sus intereses grupales o colectivos en un marco de máxima autonomía.

\section{- Principio de democracia sindical}

Nos señala que las organizaciones sindicales deben ser gobernadas por sus propios afiliados democráticamente elegidos.

Lo negativo de una democracia sindical estaría en la burocratización de sus dirigentes, produciéndose una separación entre éstos y las bases, siendo muy frecuente que las decisiones tomadas por los dirigentes se realicen al margen de sus afiliados.

\section{Principio de representatividad sindical}

Está íntimamente vinculado al principio de la democracia sindical. Nos plantea que los dirigentes sindicales deben representar proporcionalmente al número de sus afiliados. Esto lo observamos generalmente en las organizaciones sindicales de segundo y tercer grado, donde la junta directiva debe estar debidamente representada por los diferentes organismos sindicales de base o la pluralidad de éstos.

\subsubsection{Fuentes}

\section{- Fuentes generales del Derecho Laboral}

La ley.- Norma escrita dictada por el orden público, frente a las necesidades y para el bien de la convivencia social. La ley es aprobada por el Congreso de la República y es promulgada por el Presidente de la República. No debemos olvidar que nuestro ordenamiento legal se puede graficar en una pirámide en cuyo vértice 
encontramos a la Ley de Leyes, la Constitución del Estado y en segundo término a la ley ordinaria y demás normas de menor jerarquía.

La costumbre.- Conjunto de hábitos o prácticas que son regularmente mantenidos en una comunidad o profesión. Estas prácticas son aceptadas y se constituyen en normas obligatorias para los miembros de una comunidad. Muchos derechos actuales de los trabajadores se iniciaron como prestaciones voluntarias de parte del empleador, pero que al repetirse periódicamente se convirtieron en obligatorias.

La jurisprudencia.- Conjunto de resoluciones o fallos firmes o definitivos de las autoridades judiciales. La jurisprudencia constituye una fuente principal para los altos órganos jurisdiccionales, en razón a que permite aplicar el mismo criterio para casos o conductas parecidos. La dimensión de esta fuente guarda relación con la amplitud del campo que le dejan a los fallos de los tribunales de trabajo las apuntadas características de la legislación laboral, así como con el peso que adquieren las convicciones de los magistrados en las decisiones judiciales sobre la materia social.

La doctrina.- Conformada por los puntos de vista y opiniones de los estudiosos del Derecho en materia laboral. Estas opiniones están expresadas en obras especializadas, conferencias, investigaciones, revistas científicas y resoluciones de los congresos especializados.

Cabanellas (2002, p. 133) señala que doctrina es el conjunto de tesis y opiniones de los tratadistas y estudiosos del Derecho que explican y fijan el sentido de las leyes o sugieren soluciones para cuestiones aún no legisladas. Tienen importancia como fuente mediata del derecho, ya que el prestigio y la autoridad de los destacados juristas influyen a menudo sobre la labor del legislador e incluso en la interpretación judicial de los textos vigentes.

Por otra parte, la doctrina desempeña un importante papel en tanto que fuente de conocimiento y en la reglamentación de los derechos y deberes y garantía vinculados al trabajo que, por ser inherentes a la personalidad humana, tienen rango constitucional. 


\section{- Principios del Derecho Laboral.-}

Preceptos normativos que se aplican ante la ausencia o vacíos de la ley laboral.

\section{- Fuentes especiales del Derecho Laboral:}

El contrato de trabajo.- El contrato de trabajo, de acuerdo con el eminente laboralista Cabanellas (2002, p. 133), es aquel que tiene por objeto la prestación continuada de servicios privados y con carácter económico y por el cual una de las partes da una remuneración o recompensa a cambio de disfrutar o de servirse bajo su dependencia o dirección de la actividad profesional de otro.

El convenio colectivo de trabajo.- Es aquel suscrito por las organizaciones sindicales con sus respectivos empleadores. Generalmente se establece después de solucionados los pliegos de reclamos y que contienen incrementos de remuneraciones y mejoras en las condiciones de trabajo.

La convención colectiva o contrato colectivo de trabajo es el producto final de la negociación. Es la figura jurídica a través de la cual los conflictos de intereses dejan de ser tales, para dar lugar a un acuerdo que conlleve a la solución de los conflictos y a la armonía laboral, y por ende a la paz social. Se debe resaltar que internacionalmente se aceptan diversas locuciones al respecto. Así podemos citar la de: contrato de paz social, concordato de trabajo, tratado intersindical, acuerdo corporativo, capitulaciones colectivas, pacto de trabajo, contrato colectivo, entre otros.

El reglamento interno de trabajo.- Constituye la norma que regula las relaciones internas de una empresa, y debe estar autorizado y refrendado por la autoridad de trabajo.

El reglamento interno de trabajo debe contener las principales disposiciones que regulan las disposiciones laborales, entre ellas:

\section{- Fuentes específicas del Derecho Colectivo del Trabajo}

Entre las fuentes normativas relacionadas específicamente con el Derecho Colectivo del Trabajo podemos mencionar las siguientes: 
a. La Constitución de 1993.

b. La Declaración Universal de los Derechos Humanos.

c. Los Convenios 87 "Convenio sobre la Libertad Sindical y la Protección del Derecho de Sindicalización (1948)", 98 "Convenio sobre el derecho de sindicalización y de negociación colectiva (1949)" y 151 "Convenio sobre las relaciones de trabajo en la administración pública (1978)” de la OIT.

d. El Pacto Internacional de los Derechos Económicos Sociales y Culturales.

e. La Convención Americana sobre Derechos Humanos (Protocolo de San Salvador).

f. El Código Penal, Delitos contra la libertad de trabajo

g. Las leyes laborales.

A estas fuentes normativas debes adicionar algunas fuentes específicas consideradas en la Ley 28175 Ley Marco del Empleo Público:

- Las directivas emitidas por la Autoridad Nacional del Ser-vicio Civil (Servir)

Esta fuente es muy importante en razón que actualmente ya se tiene un ente rector de la gestión de los recursos humanos en la Administración Pública, ya que, por más de veinte años, desde la disolución del Instituto Nacional de Administración Pública (INAP), no se tenía una dirección centralizada y cada entidad solucionaba sus problemas de personal en forma independiente y de manera inorgánica. Contando ya con Servir se uniformizarán los procedimientos y se trabajará en una forma más armónica en materia de personal.

- Las resoluciones calificadas como vinculantes por el Tribunal del Servicio Civil El Tribunal del Servicio Civil en uso de la potestad de la Sala Plena tiene facultades para emitir precedentes administrativos de observancia obligatoria, con los efectos y alcances precisados en los fundamentos Sexto y Décimo del Acuerdo Plenario aprobado por Resolución de Sala Plena 001-2010-SERVIR/TSC.

Esta facultad se ha otorgado con el fin de establecer directrices precisas que garanticen la uniformidad en la aplicación de las normas interpretadas en todos los componentes y ámbitos del sistema administrativo de gestión de los recursos humanos, como garantía de la plena vigencia de los principios de igualdad ante la 
Ley, seguridad jurídica, buena fe, interdicción de la arbitrariedad y buena administración, que constituyen el fundamento principal de la emisión de precedentes administrativos de observancia obligatoria.

Los pronunciamientos y consultas calificadas como vinculantes por la Autoridad Nacional del Servicio Civil.

Estos pronunciamientos y consultas calificadas como vinculantes por SERVIR se encuentra relacionada con las directivas emitidas,

\subsection{Etapas del Procedimiento de la Negociación Colectiva}

La Ley de relaciones colectivas de trabajo, establece cuatro etapas en el proceso de negociación:

\subsubsection{Trato Directo}

La primera parte de una negociación colectiva en general es conocida como "trato directo". Esta es la primera etapa de la negociación la que generalmente se realiza en el interior de la empresa o institución sin ningún tipo de intermediarios en la que los trabajadores o servidores exponen su pliego de peticiones sustentándolo y defendiendo sus posiciones basándose en sus NECESIDADES. Los representantes de la empresa o institución también exponen sus puntos de vista explicando la situación económica y financiera de ésta, es decir, sus POSIBILIDADES para la solución del pliego de peticiones

Las normas no mencionan la necesidad de suscribir actas en cada reunión de las partes negociadoras pero si estarían facultadas para suscribirlas en especial si llegan a acuerdos parciales y totales, comunicando de estos hechos a las autoridades correspondientes. 
Figura 4.1.

Flujograma General De La Negociación Colectiva

Tuo Del D. Ley № 25593 - Reglamento D.S. 011-92-Tr

60 días anteriores 0

30 dias posteriores

al vencimiento del convenio

Huelga

Trato Directo

Presentación

delpliego

2. Se Inicia el trato

Directo -10

días

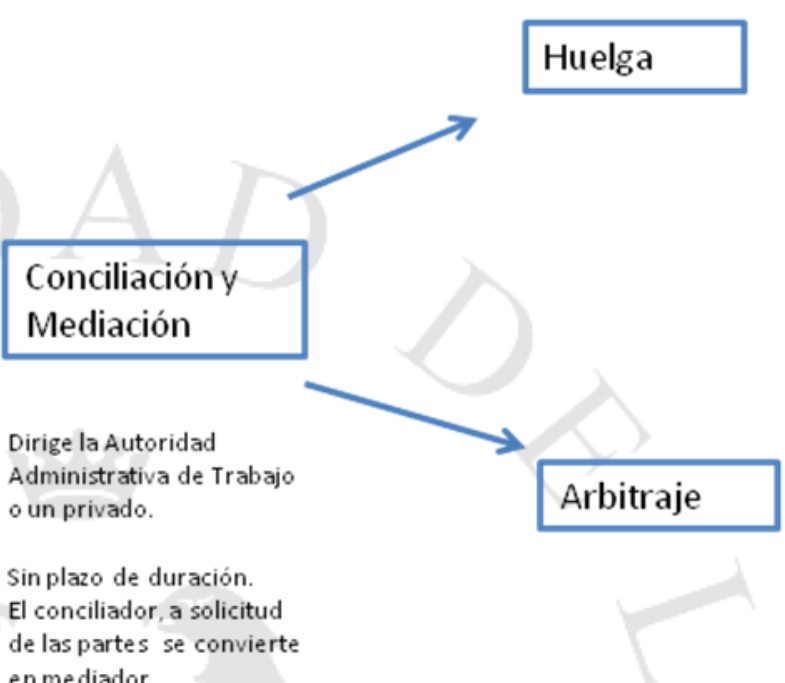

en me diador

Fuente: Elaboración propia

\subsubsection{Conciliación o Mediación}

Estas figuras procesales son mecanismos que sirven para poner fin o dar solución a un conflicto de intereses y son de singular importancia en el esquema de las relaciones colectivas de trabajo.

La conciliación proviene del latín conciliare, significa, según el Diccionario de la Real Academia Española: componer, ajustar los ánimos de quienes estaban opuestos entre sí.

La acción de conciliación, puede deberse a una acción espontánea o por los medios de un tercero. En nuestro caso, la intervención del tercero está dada por la Autoridad Administrativa de Trabajo, dejando abierta la posibilidad a las partes, si así lo acuerdan de encomendar la conciliación a personas privadas.

La mediación, es una figura que no es nueva en la doctrina jurídica y es de uso generalizado en el Derecho Internacional Público. En el campo que nos ocupa, la mediación es un sistema intermedio entre la conciliación y el arbitraje. Para solucionar la controversia se recurre a personas que con el carácter de expertos o influyentes 
examinarán el conflicto planteado o informarán respecto a sus causas, efectos y soluciones. Los mediadores pueden formular un proyecto de recomendación para ser sometido a las partes en discordia. El mediador puede surgir más bien por "generación espontánea", ya que, de proponerlo ambas partes, se estaría ante un amigable componedor. Como norma general, el mediador solamente recomienda a las partes en conflicto una determinada solución; propone ésta pero las partes pueden aceptarla o rechazarla.

\subsubsection{Arbitraje \\ Definición}

Es el mecanismo por el cual un tercero, denominado árbitro, tiene capacidad para resolver el conflicto laboral a través de un documento denominado "Laudo arbitral". Debemos precisar que el arbitraje surge ante la imposibilidad de acuerdo entre los trabajadores y los empleadores en la etapa de trato o negociación directa. Aun cuando el laudo arbitral sea de obligado cumplimiento, habitualmente no es ejecutorio como lo es una sentencia de tribunal, sino que se asemeja por su naturaleza jurídica a un convenio colectivo, que obliga jurídicamente a las partes, pero cuya ejecución requiere de la presentación de una demanda a los tribunales.

De lo expuesto, podemos afirmar que, contrariamente a lo que ocurre en la conciliación y la mediación, la responsabilidad de resolver el conflicto no recae ya en las partes, sino en el tercero que interviene como árbitro. La palabra "arbitraje" proviene del vocablo latín arbitrari, que significa "dar o pronunciar sentencia", y es lógico, pues, que se aplique a un procedimiento que se asemeja a una actuación judicial. Sin embargo, originalmente el árbitro de los conflictos del trabajo no era un juez nombrado por los poderes públicos, sino una persona seleccionada por las partes interesadas. Aún hoy se sigue aplicando este concepto en el arbitraje comercial e internacional, pero en el campo laboral es hoy corriente que el árbitro sea elegido por las autoridades o sea funcionario público.

La Ley de Relaciones Colectivas de Trabajo promulgada mediante el Decreto Ley $\mathrm{N}^{\circ} 25593$ incorporó el arbitraje como uno de los medios de dar solución a los pliegos de reclamos presentados por los trabajadores cuando no hubiesen sido resueltos a través del trato directo con sus empleadores. 
El arbitraje no es una institución nueva en el Derecho Laboral ya que ha sido usado parcialmente con anterioridad al Decreto-Ley mencionado. Sin embargo, en la actualidad la regulación del arbitraje aparece sistematizada en la ley y como una opción aplicable a todo el ámbito laboral de la actividad privada para resolver los desacuerdos entre trabajadores y empresarios que puedan surgir en la tramitación de los pliegos de reclamos, como ya se ha indicado. El arbitraje constituye uno de los caminos por los que se conduce la negociación colectiva después de haber fracasado el trato directo y la mediación. El otro camino es la huelga. De ahí la importancia que adquiere como medio de solución de conflictos por lo que se percibe a través de los medios especializados un incremento de los casos en que se opta por esta vía de solución a medida que se van conociendo sus mecanismos de funcionamiento y cuando las organizaciones sindicales estiman por diversas razones que la huelga no les va a deparar los resultados esperados. La ley establece un procedimiento expeditivo y breve basado en los principios de oralidad, sencillez, celeridad, inmediación y lealtad (art. 64 del Decreto-Ley 25593), y el Reglamento prescribe un plazo de treinta días para su tramitación así como cinco días adicionales para dar a conocer a las partes el laudo (arts. 55 y 56); sin embargo, también señala que para resolver el conflicto el árbitro o el Tribunal Arbitral deberá tener presente las conclusiones del dictamen de la oficina especializada del Ministerio de Trabajo y Promoción Social (Dirección de Economía y Productividad).

La OIT manifiesta que el arbitraje es un procedimiento en el cual un tercero (que puede ser una persona física, una junta de árbitros o un tribunal arbitral) está facultado para tomar una decisión que ponga fin al litigio. Si la decisión se refiere a un conflicto jurídico y supone la determinación de los derechos y las obligaciones de las partes, tiene una función similar a la de una sentencia judicial. Si se refiere a un conflicto de intereses (o económico), su efecto es reemplazar la negociación por un laudo que la tercera parte considera adecuado. En ambos casos, aun cuando el laudo arbitral sea de obligado cumplimiento, habitualmente no es ejecutorio como lo es una sentencia de tribunal, sino que se asemeja por su naturaleza jurídica a un convenio colectivo, que obliga jurídicamente a las partes, pero que para hacerlo ejecutar requiere la presentación de una demanda ante los tribunales.

\section{Tipos de arbitraje}


La decisión de someterse al arbitraje puede surgir de las partes en conflicto o de la resolución del legislador. En el primer supuesto nos encontramos ante el arbitraje convencional, autónomo o libre y en el segundo ante el arbitraje obligatorio, imperativo o legal. Uno y otro ofrecen ventajas e inconvenientes. Sin perjuicio de ampliaciones en las respectivas voces. Ante la debilidad congénita del convencional, que no impide las huelgas, la preferencia doctrinal está por el impuesto, donde el poder administrativo asume función decisoria por sí o por organismos especializados.

\section{Arbitraje convencional}

El arbitraje convencional o voluntario puede revestir tres formas principales:

a) La sumisión voluntaria, es decir, con el acuerdo de las dos partes, y entendiéndose que el laudo está sujeto a la aceptación de ambas.

b) La sumisión obligatoria, es decir a instancia de parte o por decisión de la autoridad competente, y con el laudo igualmente sujeto a la aceptación de las dos partes

c) La sumisión voluntaria, pero con la obligación legal de cumplir con el laudo.

\section{Arbitraje Potestativo}

El arbitraje potestativo es de reciente data en nuestra legislación, y su naturaleza jurídica establece la obligatoriedad de optar por el arbitraje cuando una de las partes lo solicita.

En la negociación colectiva peruana se reguló con el D. S. 014-2011-TR a través del cual se adicionó el Art. 61-A al texto del Reglamento de la Ley de Relaciones Colectivas de Trabajo aprobado por el D. S. 011-2011-TR. El texto del Decreto Supremo 014-2011-TR estableció entre otros aspectos, la inclusión de la figura del Arbitraje Potestativo, institución jurídico laboral por el cual y según las normas nacionales de Derecho del Trabajo, cualquiera de las partes, ante la falta de acuerdo en la negociación colectiva, puede someter a la otra parte a un procedimiento de arbitraje en donde un tercero deberá de dar solución al conflicto de intereses económicos. Debemos recordar que el arbitraje potestativo ha sido cuestionado por el sector 
empresarial al considerarlo inconstitucional porque atenta contra la libertad relacionada al elegir someterse al arbitraje.

\subsubsection{La Huelga}

La huelga es un derecho de los trabajadores, y que es reconocido por los estados democráticos como medio de defensa extrema de los trabajadores frente a la oposición de la empresa en la solución de conflictos colectivos de trabajo. Para los servidores públicos es de aplicación las normas establecidas en el régimen laboral común, es decir el TUO de la Ley de Relaciones Colectivas de Trabajo, D.S. 010-2003-TR y demás normas reglamentarias.

\section{Tipos de huelga}

\section{La Huelga atípica o irregular}

No están amparadas por la presente norma las modalidades atípicas, tales como paralización de zonal o secciones neurálgicas de la entidad, trabajo a desgano, a ritmo lento o a reglamento, reducción deliberada del rendimiento o cualquier paralización en la que los servidores civiles permanezcan en el centro de trabajo y la obstrucción del ingreso al mismo.

Las modalidades de huelga atípica o irregular establecidas en el artículo 81 del Reglamento General de la Ley 30057, son las siguientes:

\section{Paralización intempestiva}

Son aquellas paralizaciones que se realizan en forma irregular al omitirse el requisito del preaviso, es decir, son de carácter intempestivo o espontáneo. Este tipo de paralizaciones no recibe el tratamiento de huelga, por lo tanto no le ampara el derecho constitucional y legal establecido para el derecho de huelga.

Estas huelgas se presentan con paros de breve duración "media hora, una hora, dos horas o un día", que muchas veces no dan tiempo a los huelguistas a abandonar el establecimiento. Sirve a los organizadores para mandar un mensaje a los empleadores de que si no solucionan su problema podrían llegar a tomar decisiones más radicales. 


\section{Paralización de zonas o secciones neurálgicas en la empresa o institución.}

Esta constituye otra modalidad de paralización irregular o ilegal de la huelga, cuyo objeto es causar mayores daños con menores perjuicios para el sector laboral. En esta clase de medida lo que se pretende es que la acción de la minoría obligue a la inactividad de la mayoría que no participa en la paralización y que por lo tanto no sufre la pérdida del salario, lo que a su vez es perjuicio para el empleador.

Como la huelga debe originarse necesariamente en la voluntad de la mayoría y se traduce en la abstención colectiva del trabajo, la paralización de la minoría no encaja dentro de dicha concepción, pues sólo la mayoría puede declarar y llevar a cabo una huelga.

\section{Trabajo a desgano, ritmo lento o a reglamento}

La huelga implica una paralización de las actividades o sea una abstención total de la prestación del servicio. En el trabajo a desgano o a ritmo lento se da la presencia física del trabajador quien presta el servicio pero sin el rendimiento laboral esperado o convenido, o retardando deliberadamente los movimientos necesarios para la prestación del servicio. El trabajo a desgano constituye una forma de reducción deliberada de la producción y se califica como incumplimiento de una de las obligaciones principales que el trabajador asume por el contrato de trabajo, que es la prestación eficiente del servicio. Además, tanto el trabajo a desgano como el prestado a ritmo lento constituyen una violación a la buena fe laboral, pretendiéndose con estas modalidades continuar con la percepción de la remuneración sin la contraprestación debida del servicio.

En el trabajo a reglamento, la modalidad es similar por cuanto se presenta un entorpecimiento deliberado del servicio, pero encubierto por un aparente y exigente cumplimiento de las reglas existentes para la prestación del mismo.

\section{Reducción deliberada del rendimiento}

Esta es una modalidad de incumplimiento de las obligaciones laborales especialmente de aplicación a aquellos trabajadores cuyo esfuerzo tiene una producción susceptible de ser medida, pues obviamente hay trabajos en los que el resultado no es visible. Debe 
recordarse que el inciso b. del Art. $61^{\circ}$ del Texto Único Ordenado de la Ley de Fomento del Empleo, al describir las faltas graves, considera como tal, la disminución deliberada y reiterada en el rendimiento de las labores o del volumen de la calidad de producción, verificada fehacientemente o con el concurso de los servicios inspectivos del Ministerio de Trabajo y Promoción del Empleo, el que podrá solicitar el apoyo del sector al que pertenece la empresa.

\section{Paralización con permanencia en el centro de trabajo}

Tal como lo señala el Art. $72^{\circ}$ de la Ley de Relaciones Colectivas de Trabajo, aplicada supletoriamente al Ser vicio Civil, la huelga tiene entre otras notas características que ella debe realizarse con abandono del centro de trabajo, lo que significa que toda paralización con permanencia no tiene la protección de la ley.

El no abandonar los establecimientos o centros de trabajo durante un estado de huelga podría considerarse como una toma ilegal del local, de naturaleza penal que puede ser demandado a las autoridades correspondientes, ya que en muchos casos viene acompañada con la prohibición de salida de funcionarios y empleados que no están de acuerdo con ella catalogándose este acto como toma de rehenes.

\section{Obstrucción al ingreso al centro de trabajo}

De acuerdo con la concepción que contiene la ley, no se hace necesaria ninguna obstrucción para el ingreso al centro de trabajo de los que no intervienen en la paralización, pues de haberse votado la huelga de acuerdo con lo que estipula la norma, existe prohibición de ingreso al centro laboral por parte de los trabajadores, con excepción solamente de los trabajadores de confianza y dirección. Tienen derecho de ingresar a la empresa todos aquellos que no están comprendidos dentro de la mencionada categoría así como terceros ajenos a la empresa (clientes). Tienen a su vez la obligación de ingresar a la empresa aquellos trabajadores que deben realizar las labores indispensables para la realización del Art. $78^{\circ}$ del TUO de la LRCT.

Ámbito y vigencia de Ia huelga

La huelga puede comprender a una entidad pública, a uno o varios de sus 
establecimientos, o a cualquier ámbito según la organización sindical comprometida. Asimismo, podrá ser declarada por un tiempo determinado o indefinido. Si no se indica previamente su duración, se entenderá a plazo indefinido.

\subsection{Regulación de la Negociación Colectiva en la Ley del Servicio Civil}

El derecho a la negociación colectiva en el servicio civil ha evolucionado desde una prohibición a este en el Decreto Ley 11377 Ley del Estatuto y Escalafón del Servicio Civil, hasta la Ley 30057 Ley del Servicio Civil, en la que e establece este derecho pero con graves restricciones como es el caso de la prohibición de la negociación colectiva en materia económica o remunerativa. Lo antes mencionado se puede observar en la siguiente Tabla:

Tabla 4.1.

Evolución de La normatividad del Derecho a la Negociación Colectiva

Norma

Decreto Ley 11377,
Estatuto y Escalafón del
Servicio Civil

(6 de junio de 1950)

Decreto Legislativo. 276, Ley de Bases de la Carrera Administrativa.

(6 de marzo de 1984)

\section{Detalle}

"Los empleados públicos podrán asociarse solo con fines culturales, deportivos, asistenciales o cooperativos. Dichas asociaciones están prohibidas de adoptar la denominación u organización propias de los sindicatos, de adoptar las modalidades de acción de estos organismos, de ejercer coacción en sus peticiones y de recurrir a la huelga". (Art. 49)

Las entidades públicas están prohibidas de negociar con sus servidores, directamente o a través de sus organizaciones sindicales, condiciones de trabajo o beneficios que impliquen incrementos remunerativos o que modifiquen el Sistema Único de Remuneraciones que se establece por la presente Ley, en armonía con lo que dispone el Artículo $60^{\circ}$ de la Constitución Política del Perú. Es nula toda estipulación en contrario. (Art.44)

D.S. 003-82-PCM, El sindicato mayoritario de la respectiva repartición, podrá presentar Servidores públicos y sus anualmente, en forma escrita, su pliego de peticiones sobre organizaciones condiciones generales de trabajo. (Art. 24) sindicales. El Art. $25^{\circ}$ se refiere procedimiento de la Comisión Paritaria

(22 de enero de 1982)

$\begin{array}{lll}\begin{array}{l}\text { Ley 30057 Ley } \\ \text { Servicio Civil }\end{array} & \text { del } & \begin{array}{l}\text { Art. } 42 . \\ \text { empleo: } \text { Lolicitudes e cambio e condiciones e trabajo o condiciones e }\end{array} \\ \text { (4 de julio de 2013) } & \begin{array}{l}\text { compensaciones no económicas, incluyendo el cambio }{ }^{7} \text { de condiciones } \\ \text { de trabajo o condiciones de empleo, de acuerdo con las posibilidades } \\ \text { presupuestarias y de infraestructuras de la entidad y la naturaleza de las } \\ \text { funciones que en ella se cumplan. }\end{array}\end{array}$

\section{Artículo 43. Inicio de la negociación colectiva}

La negociación colectiva se inicia con la presentación de un pliego de reclamos que debe contener un proyecto de convención colectiva, con

\footnotetext{
${ }^{7}$ Declarado Inconstitucional por la STC ${ }^{\circ} 0025-2013-\mathrm{AI} / \mathrm{TC}$
} 
lo siguiente:

(...) e) Las peticiones que se formulan respecto a condiciones de trabajo o de empleo que se planteen deben tener forma de cláusula e integrarse armónicamente dentro de un solo proyecto de convención. Se consideran condiciones de trabajo o condiciones de empleo los permisos, licencias, capacitación, uniformes, ambiente de trabajo y, en general, todas aquellas que faciliten la actividad del servidor civil para el cumplimiento de sus funciones.

\section{Artículo 44. De la negociación colectiva}

La negociación y los acuerdos en materia laboral se sujetan a lo siguiente:

a) El pliego de reclamos se presenta ante la entidad pública entre el 1 de noviembre y el 30 de enero del siguiente año.

b) La contrapropuesta o propuestas de la entidad relativas a compensaciones económicas son nulas de pleno derecho. ${ }^{8}$

c) Las negociaciones deben efectuarse necesariamente hasta el último día del mes de febrero. Si no se llegara a un acuerdo, las partes pueden utilizar los mecanismos de conciliación hasta el 31 de marzo.

d) Los acuerdos suscritos entre los representantes de la entidad pública y de los servidores civiles tienen un plazo de vigencia no menor de dos (2) años y surten efecto obligatoriamente a partir del 1 de enero del ejercicio siguiente. Similar regla se aplica a los laudos arbitrales.

e) Los acuerdos y los laudos arbitrales no son de aplicación a los funcionarios públicos, directivos públicos ni a los servidores de confianza. Es nulo e inaplicable todo pacto en contrario.

Son nulos los acuerdos adoptados en violación de lo dispuesto en el presente artículo.

Están prohibidos de representar intereses contrarios a los del Estado en procesos arbitrales referidos a la materia de la presente Ley o en los casos previstos en el presente artículo quienes ejercen cargos de funcionarios o directivos públicos, incluso en los casos en que los mismos se realicen ad honorem o en órganos colegiados. Esta prohibición también alcanza a cualquiera que ejerza como árbitro o conciliador.

Decreto Supremo 0402014-PCM, Reglamento General de la Ley 30057 , Ley del Servicio Civil. (13 de junio de 2014).

\section{Artículo 66.- Alcances de la negociación colectiva}

La negociación colectiva por entidad pública se circunscribe a lo establecido en el artículo 42 de la Ley y en el literal e) de su artículo 43 y se encuentra además limitada por lo dispuesto en el tercer párrafo del artículo 40 y en el literal b) del artículo 44 de la misma Ley. ${ }^{9}$

\section{Artículo 68.- Definición de convenio colectivo}

El convenio colectivo es el acuerdo que celebran, por una parte, una o más

organizaciones sindicales de servidores civiles y, por otra, entidades públicas Tipo A que constituyen Pliego Presupuestal.

De conformidad con lo establecido en el artículo 42 de la Ley, el objeto de dicho acuerdo es regular la mejora de las compensaciones no económicas, incluyendo el cambio de condiciones de trabajo o de

\footnotetext{
8 Ídem

9 Ídem.
} 
empleo, de acuerdo con las posibilidades presupuestarias y de infraestructura de la entidad y la naturaleza de las funciones que en ella se cumplen.

Fuente: Normas con rango de Ley y y de rango reglamentario pertinentes.

De acuerdo a lo detallado en la Tabla anterior podemos concluir que el derecho a la negociación colectiva de la concepción estatutaria (Decreto Ley 11377 - Ley de Estatuto y Escalafón de la Ley de Servicio Civil, en la que se prohibía, no solamente el derecho a la negociación colectiva, sino también el derecho de huelga de los servidores públicos), hasta la presente normativa, Ley 30057, donde prácticamente se encuentran establecidos los derechos laborales de los servidores públicos. Algunos artículos de ésta norma, que afectaban el derecho a la negociación colectiva, fueron declarados inconstitucionales por la Sentencia recaída en el expediente 0025-2013-AI/TC emitido por el Tribunal Constitucional recientemente.

\subsection{El procedimiento de negociación colectiva en el régimen del Servicio Civil.}

La Ley 30057, Ley del Servicio Civil ha dado el marco normativo para establecer el nuevo procedimiento de la negociación colectiva del servicio civil tomando algunas características del procedimiento que se realiza en el régimen laboral privado (TUO de la Ley de Relaciones Colectivas de Trabajo y su Reglamento) y algunas del establecido en el régimen laboral público (Decreto Legislativo 276 y su Reglamento).

A continuación se presenta sobre la base de la Ley y su Reglamento general del nuevo procedimiento de negociación colectiva en el servicio civil

\section{Aspectos generales}

1. La negociación colectiva se inicia con la presentación, de un pliego de reclamos ante el Jefe de la Oficina de Recursos Humanos de la Entidad, el cual debe contener todo lo establecido por el artículo 43 de la Ley y su Reglamento. Es decir:

- Nombre o denominación social y domicilio de la entidad pública a la cual se dirige. 
- Denominación y número de registro del o de los sindicatos que lo suscriben, y domicilio único que señalen para efectos de las notificaciones.

- De no existir sindicato, las indicaciones que permitan identificar a la coalición de trabajadores que lo presenta.

- La nómina de los integrantes de la comisión negociadora que no puede ser mayor a un servidor civil por cada 50 servidores civiles de la entidad que suscriben el registro del sindicato hasta un máximo de seis servidores civiles.

- Las peticiones que se formulan respecto a condiciones de trabajo o de empleo que se planten deben tener forma de cláusula e integrarse armónicamente dentro de un solo proyecto de convención. Se consideran condiciones de trabajo o condiciones de empleo los permisos, licencias, capacitación, uniformes, ambiente de trabajo y, en general, todas aquellas que faciliten la actividad del servidor civil para el cumplimiento de sus funciones.

- Firma de los dirigentes sindicales designados para tal fin por la asamblea, o de los representantes acreditados, de no haber sindicato.

Dicho pliego debe necesariamente presentarse entre el 1 de noviembre y el 30 de enero del año siguiente.

De acuerdo al artículo 73 del Reglamento General de la Ley del Servicio Civil, el plazo de negociación debe culminar como máximo hasta el 15 de junio del año en curso, por razones de orden presupuestal, caso contrario el acuerdo regirá en el periodo anual subsiguiente.

\section{Constitución de Comisiones negociadoras}

En el marco de la negociación colectiva, las entidades públicas y las organizaciones sindicales deberán constituir sus respectivas Comisiones Negociadoras.

En el caso de los servidores civiles, la Comisión Negociadora está compuesta hasta por tres (03) representantes, cuando el pliego sea presentado por una organización sindical que represente a menos de cien (100) servidores, incorporándose un (01) representante más por cada cincuenta (50) servidores adicionales, con un número máximo de seis (06) representantes. 
Cada entidad pública establecerá el número de miembros de su Comisión Negociadora y su conformación, respetando el límite máximo indicado en el párrafo anterior.

\section{Remisión del Pliego de Reclamos a SERVIR y al MEF}

Recibido el pliego de reclamos, y antes de iniciar la negociación, de conformidad al artículo 72 del reglamento general, el Jefe de la Oficina de Recursos Humanos de la entidad, antes de iniciar la negociación colectiva, remitirá copia del mismo a la Autoridad Nacional del Servicio Civil -SERVIR y una copia al Ministerio de Economía y Finanzas; que a través de la Dirección General de Gestión de Recursos Públicos, podrá opinar respecto a si alguna de las peticiones contenidas en el mismo implica una contravención a todo establecido en el párrafo final del artículo 40 de la Ley o acerca de algún otro aspecto sobre el cual estimara pertinente pronunciarse.

La no emisión de opinión por parte de dicho Ministerio no se entenderá como conformidad u opinión favorable del mismo. La emisión o no emisión de dicha opinión no afecta el inicio de la negociación colectiva.

\subsubsection{El procedimiento directo de la negociación colectiva en el Servicio Civil]}

\subsubsection{Negociación directa}

Las partes informaran a la Autoridad Nacional del Servicio Civil -SERVIR el inicio de la negociación colectiva y, en su momento, su culminación. SERVIR comunicara de estos hechos a la Autoridad Administrativa de Trabajo correspondiente.

La primera parte de una negociación colectiva en general es conocida como "trato directo". Esta es la primera etapa de la negociación la que generalmente se realiza en el interior de la empresa o institución sin ningún tipo de intermediarios en la que los trabajadores o servidores exponen su pliego de peticiones sustentándolo y defendiendo sus posiciones basándose en sus NECESIDADES. Los representantes de la empresa o institución también exponen sus puntos de vista explicando la situación económica y financiera de ésta, es decir, sus POSIBILIDADES para la solución del pliego de peticiones 
Las normas no mencionan la necesidad de suscribir actas en cada reunión de las partes negociadoras pero si estarían facultadas para suscribirlas en especial si llegan a acuerdos parciales y totales, comunicando de estos hechos a las autoridades correspondientes.

\subsubsection{La conciliación y la mediación}

Si hasta el último día de febrero las partes no hubieran llegado a un acuerdo, cualquiera de ellas podrá solicitar el inicio de un procedimiento de conciliación. La función conciliatoria estará a cargo de un cuerpo técnico especializado y calificado de Ia Autoridad Administrativa de Trabajo.

El procedimiento de conciliación deberá caracterizarse por la flexibilidad y la simplicidad en su desarrollo, debiendo el conciliador desempeñar un papel activo en la promoción del avenimiento entre las partes. Si estas lo autorizan, el conciliador podrá actuar Como mediador, a cuyo efecto, en el momento que lo considere oportuno, presentará una o más propuestas de solución que las partes pueden aceptar o rechazar.(Art. 72 del Reglamento Gral.)

\section{La conciliación}

De acuerdo a la norma del Servicio Civil es la etapa en que se reúnen los representantes de los servidores y de la institución pública, bajo la presencia de un conciliador designado por la Autoridad Administrativa de Trabajo. En esa etapa las partes reciben el apoyo de un facilitador cuya misión es instar a las partes a lograr un acuerdo.

Se realizarán tantas reuniones de conciliación como sean necesarias, a voluntad de las partes. Si una de ellas no concurriera o si concurriendo no estuviera de acuerdo con proseguir con ellas, se tendrá por concluida esta etapa.

\section{La mediación}

La conciliación se convertirá en mediación si las partes proponen al conciliador realice un estudio del pliego de peticiones y del análisis económico y financiera de la entidad y proponga a las partes una fórmula de solución, la cual puede ser rechazada o aceptada. 
Al término de dicho plazo, si no se hubiera logrado acuerdo, el mediador convocará a la partes a una audiencia en la que éstas deberán formular su última propuesta en forma de proyecto de convención colectiva. El mediador presentará una propuesta final de solución, la que de no ser aceptada, pondrá fin a su gestión.

A continuación se grafica el flujograma del procedimiento de negociación colectiva en el servicio civil.

Figura 4.2

Flujograma general de la Negociación Colectiva -Régimen Servicio Civil

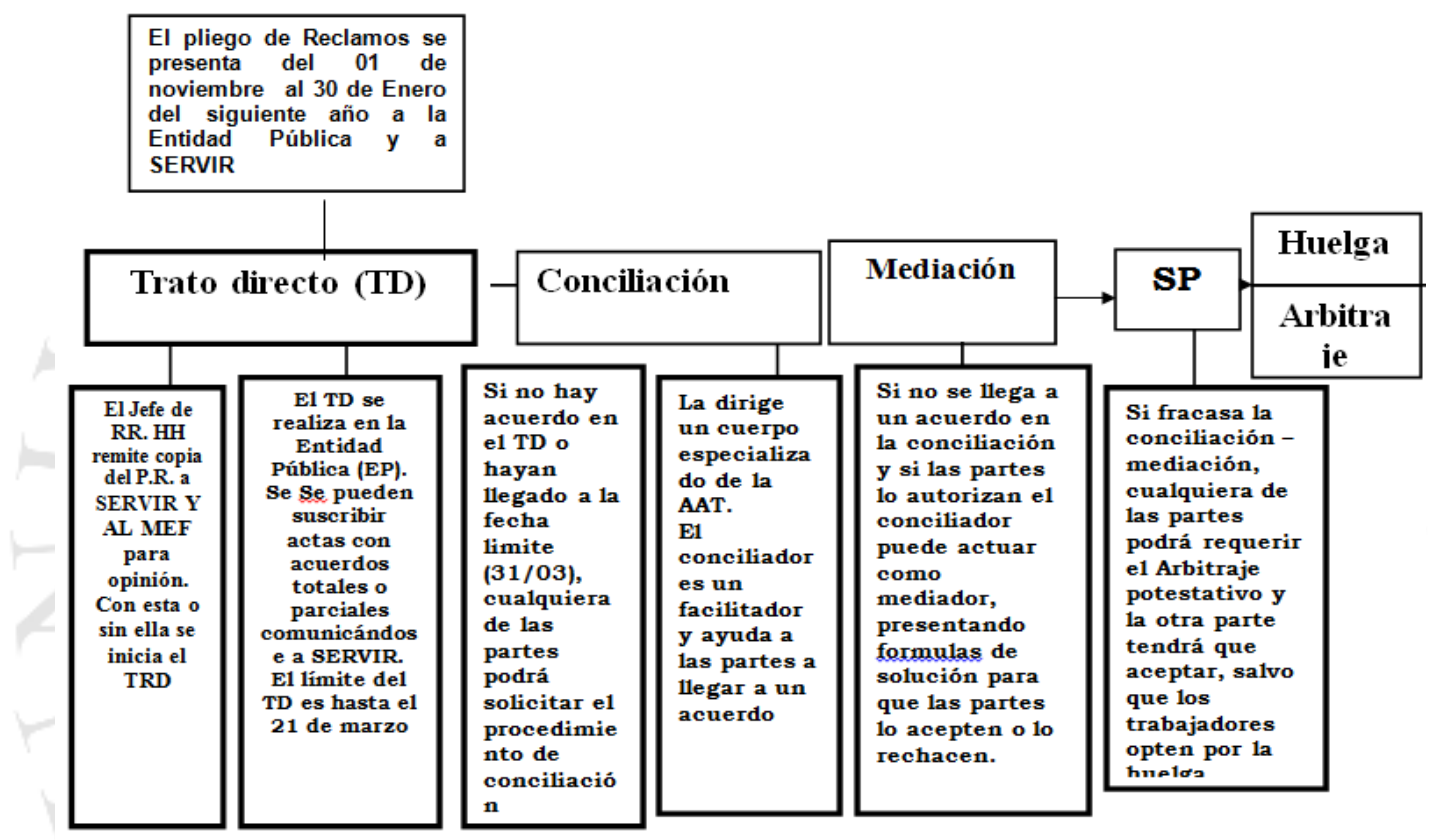

Fuente: elaboración propia en base a la Ley 30057 y su Reglamento General.

\subsubsection{Arbitraje}

El arbitraje es una de las instituciones más utilizadas en la solución pacífica de los conflictos de toda naturaleza, especialmente en los de materia laboral.

Este es uno de los medios que se utilizan en la búsqueda de solución de divergencias ante un petitorio de reclamos, cuando las partes directamente no pueden lograr el acuerdo. Tradicionalmente, el arbitraje tenía como característica que el órgano arbitral definía el contenido del laudo a su libre criterio y conciencia, teniendo en cuenta las posiciones de las partes. En los últimos años se han venido perfeccionando nuevas formas de solucionar los conflictos de intereses, atendiendo no tanto al método 
de solución, sino más bien a incentivar a las partes para que conjuntamente logren la solución.

La norma reglamentaria respecto de la Ley de Arbitraje, en su artículo 74 ha establecido que de no llegarse a acuerdo en la etapa de conciliación, cualquiera de las partes podrá requerir el inicio de un proceso arbitral potestativo, que formara parte del proceso de negociación colectiva, salvo que los trabajadores decidan irse a la huelga.

\section{El arbitraje potestativo en las instituciones públicas}

En el caso del procedimiento arbitral en las entidades y empresas de la Administración Pública, que en muchos casos aplica la del régimen laboral común, también se ha instituido lo que se conoce con el nombre de Arbitraje Potestativo en la Administración Pública establecido con la Ley 29812, Ley del Presupuesto del Sector Público para el año 2012, publicada el 9 de diciembre del 2011.

La citada disposición dice lo siguiente:

QUINCUAGÉSIMA CUARTA. A partir de la vigencia de la presente Ley en adelante, en los procesos de negociación colectiva y/o arbitraje en materia laboral, en donde participen entidades públicas y empresas del Estado, los árbitros deben aplicar solo las normas de derecho respectivas y presupuestarias vigentes.

Corresponderá a un consejo especial nombrar al presiden-te del tribunal arbitral en caso de no ponerse de acuerdo las partes en su designación. Mediante decreto supremo se establece la conformación de dicho consejo el mismo que incluirá a un representante de la sociedad civil.

Todos los laudos arbitrales que se aprueben, a partir de la vigencia de la norma, deben ser publicados en el portal institucional del Ministerio de Economía y Finanzas, para ello, las entidades públicas y empresas públicas deben presentar, bajo responsabilidad, dichos laudos arbitrales en un plazo que no excede de los quince días de expedido el referido laudo.

Posteriormente, con fecha 17 de diciembre del 2011, se publica la Resolución Ministerial 331-2011-TR, donde se establecen los requisitos para la inscripción en el Registro Nacional de Árbitros de Negociaciones Colectivas, en donde se corrobora la imposición a las partes de aquellas empresas del Estado sujetas al régimen laboral privado, y seleccionar como árbitros únicamente a aquellos profesionales que cuenten 
con el Registro Hábil y hayan concluido el curso organizado por el propio Ministerio de Trabajo, lo cual afectaría la libertad del Sindicato de elegir libremente y con sujeción al Principio de Independencia, al profesional que lo represente en el proceso arbitral.

En consecuencia:

Se crea un Registro de Árbitros conformado por el Estado, para que resuelva conflictos económicos en donde el propio Estado es parte, toda vez que se trata de empresas estatales sujetas a un régimen laboral privado.

Se impone a las partes del conflicto árbitros del Registro del Ministerio de Trabajo y Promoción del Empleo, con formación y criterios jurídicos proestatales, toda vez que la formación de estos está a cargo del propio Ministerio de Trabajo y Promoción del Empleo.

Asimismo, se crea un organismo (Consejo Especial) que habrá de designar directamente al Presidente del Tribunal Arbitral, en caso los árbitros del registro no se pongan de acuerdo en su elección.

Este organismo especial es el antecedente legal para la implementación del Consejo de Apoyo al Servicio Civil - CASC, que se encuentra regulado en el artículo 86 del Capítulo IV de la Ley del Servicio Civil.

El arbitraje en la negociación colectiva del Servicio Civil se encuentra regulada en los artículos 74 al 78 del Reglamento General y el artículo 44 de la Ley del Servicio Civil. Lo establecido en Texto único Ordenado de la Ley de Relaciones Colectivas de Trabajo (régimen laboral privado) se aplica supletoriamente.

\section{Arbitraje en el servicio civil}

En la negociación colectiva se aplica el arbitraje potestativo, por el cual es solicitado por cualquiera de las partes si no se ha llegado a acuerdo en la etapa de conciliación o mediación. La otra parte está en la obligación de aceptar este arbitraje, salvo que los trabajadores decidan irse a la huelga.

\section{Conformación del Tribunal Arbitral}


El arbitraje estará a cargo de un tribunal integrado por tres miembros, los mismos que deberán estar inscritos en el Registro Nacional de Árbitros de Negociaciones Colectivas al que se refiere el artículo 2 del Decreto Supremo No 014-2011-TR y no podrán estar comprendidos dentro de la situación de incompatibilidad establecida en el artículo 21 del Decreto Legislativo 1071 y en el artículo 2 de la Resolución Ministerial No 3312011-TR. Será aplicable a los mismos, además, lo establecido en el artículo 28 de dicho Decreto Legislativo.

Corresponderá a las partes designar cada una de ellas a un árbitro y a estos efectuar la designación de quien presidirá el tribunal.

En el escrito con el que una de las partes comunique a la otra su decisión de recurrir a la vía arbitral, indicará también el nombre del árbitro designado por ella.

La parte que reciba esa comunicación deberá designar al otro árbitro dentro de los cinco (05) días hábiles siguientes a la fecha de recepción de la comunicación de la organización sindical. Si no efectuara dicha designación en el plazo establecido, será la Comisión de Apoyo al Servicio Civil el que lo designe. Los árbitros designados de acuerdo con lo establecido en los párrafos anteriores,

Designarán al Presidente del Tribunal. Si no llegaran a ponerse de acuerdo en un plazo máximo de cinco (5) días hábiles, contados a partir de la designación del último de ellos, corresponderá a la Comisión de Apoyo al Servicio Civil designar a quien se desempeñará como Presidente del tribunal arbitral.

Una vez aceptada su designación, el presidente del tribunal convocará a las partes a una Audiencia de Instalación, entendiéndose formalmente iniciado el arbitraje con dicha audiencia.

La siguiente Tabla nos muestra el desarrollo del arbitraje en la Ley de Servicio

\section{Civil}

Tabla 4.2.

Procedimiento arbitral potestativo en la Ley 30057 - Ley del Servicio Civil y su reglamento. Aplicación supletoria: LRCT-Art. Del $63^{\circ} \mathrm{Al} 67^{\circ}$ 


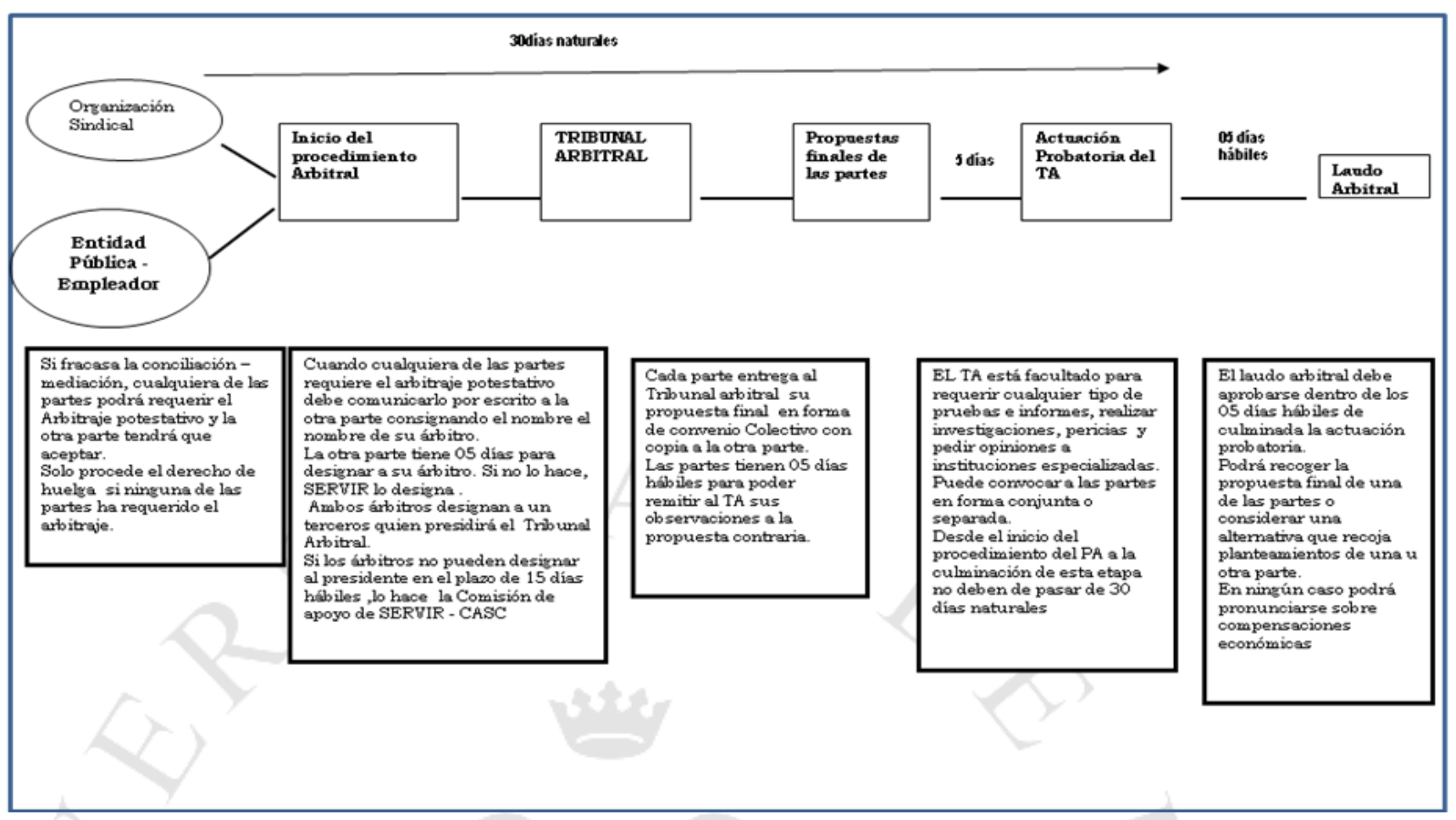

Fuente: Ley 30057, Ley del Servicio Civil y Ley de Relaciones Colectivas de Trabajo

\section{Laudo Arbitral}

En el laudo, el Tribunal Arbitral podrá recoger la propuesta final de una de las partes o considerar una alternativa que recoja planteamientos de una y otra

En el supuesto que el laudo se emita hasta el quince (15) de junio se aplicará para el siguiente periodo presupuestario. Si el laudo se emitiera luego de esa fecha, el mismo regirá en el periodo presupuestal subsiguiente.

\section{Aplicación supletoria de normas sobre arbitraje}

Las disposiciones del Decreto Legislativo 1071 y las normas sobre arbitraje contenidas en el Texto Único Ordenado de la Ley de Relaciones Colectivas de Trabajo, aprobado mediante Decreto Supremo 010-2003-TR y en su Reglamento se aplican según su naturaleza de manera supletoria y complementaria en aquello no previsto en la Ley $\mathrm{N}^{\mathrm{o}}$ 30057 y en el Reglamento General de este.

\subsubsection{El Procedimiento de huelga en el Servicio Civil}


La Ley 30057, Ley del Servicio Civil ha regulado este derecho en su artículo 45 el mismo que establece:

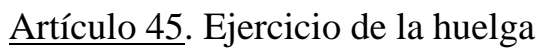

45.1 El derecho de huelga se ejerce una vez agotados los mecanismos de negociación o mediación. Para tal efecto, los representantes del personal deben notificar a la entidad sobre el ejercicio del citado derecho con una anticipación no menor a quince (15) días. Es ilegal el ejercicio del derecho de huelga que no haya cumplido con lo establecido en el presente artículo.

45.2 El ejercicio del derecho de huelga permite a la entidad pública la contratación temporal y directa del personal necesario para garantizar la prestación de los servicios mínimos de los servicios esenciales y mínimos de los servicios indispensables para el funcionamiento de la entidad, desde el inicio de la huelga y hasta su efectiva culminación.

\section{Ejercicio del derecho de huelga en el servicio civil}

Del artículo 79 al 85 del Reglamento General de la Ley del Servicio Civil se encuentra regulado el ejercicio del derecho de huelga en los siguientes términos:

\section{Definición de huelga}

La huelga es la interrupción continua y colectiva del trabajo, adoptada mayoritariamente y realizada en forma voluntaria de manera pacífica por los servidores civiles, con abandono del centro de trabajo. Los representantes de los servidores civiles deben notificar a la entidad pública sobre el ejercicio de huelga con una anticipación no menor a quince (15) días calendario.

Lo establecido por la norma en la definición de este derecho es casi igual a la establecida en el régimen general. Lo que lo diferencia es que la notificación o el aviso de la huelga para los trabajadores del régimen laboral privado son de cinco (5) días útiles. Obviamente que se beneficia la entidad pública que tendrá un mayor número de días para tomar todas las previsiones necesarias, incluyendo en ella la contratación de personal facultada por el artículo 45.2 de la Ley 30057 para garantizar la prestación de los servicio mínimos de la entidad. 


\section{Requisitos para la declaratoria de huelga}

a. La declaratoria de huelga debe cumplir con los siguientes requisitos:

b. Que tenga por objeto la defensa de los derechos e intereses socioeconómicos o profesionales de los servidores civiles en ella comprendidos.

c. Que la decisión sea adoptada en la forma que expresamente determinen los estatutos y que en todo caso representen la voluntad mayoritaria de los trabajadores comprendidos en su ámbito.

d. El acta de asamblea deberá ser refrendada por Notarlo Publico o, a falta de este, por el Juez de Paz letrado de la localidad.

e. Tratándose de organizaciones sindicales cuya asamblea este conformada por delegados, la decisión será adoptada en asamblea convocada expresamente.

f. Que sea comunicada a la entidad pública por lo menos con una anticipación de quince (15) días calendario, acompañando copia del acta de votación. La entidad deberá avisar a los usuarios de los servicios del inicio de la huelga.

g. Que la negociación colectiva no haya sido sometida a arbitraje.

En el sistema de la negociación colectiva para el régimen común se ha previsto que el derecho de huelga es excluyente al ejercicio del procedimiento arbitral, ya que los trabajadores, una vez que han fracasado las etapas del trato directo y la conciliación mediación, tienen la opción de optar entre recurrir al arbitraje o a la huelga; así lo disponen los Arts. $61^{\circ}$ y $62^{\circ}$ de la del TUO de la LRCT.

Si bien el sometimiento del conflicto a arbitraje aparece como un impedimento para el ejercicio del derecho de huelga, el Art. $63^{\circ}$ establece una excepción que la desnaturaliza, al decir: «durante el desarrollo de la huelga los trabajadores podrán, asimismo, proponer el sometimiento del diferendo a arbitraje, en cuyo caso se requerirá de la aceptación del empleador».

Nótese que en la segunda opción (de la huelga en tránsito al arbitraje), los trabajadores ya no podrán imponerlo sino que se requiere la aceptación del empleador, quien puede negarse a ello. 
Podemos hacer una comparación entre el ejercicio del derecho de huelga en el régimen laboral privado en el que los trabajadores son los que tienen la opción de elegir entre ejercer el derecho de huelga o el optar por el arbitraje potestativo ${ }^{10}$ con el ejercicio del derecho de huelga en el servicio civil, en donde la facultad de optar por el arbitraje potestativo corresponde a las dos partes (a los servidores civiles y a la entidad pública $^{11}$, salvo que los trabajadores opten por la huelga. La Tabla $\mathrm{N}^{\circ} 7$ nos ilustra las diferencias.

\section{Las labores indispensables y los servicios esenciales}

El artículo 83 y 84 del Reglamento de la Ley 30057 ha desarrollado los términos "las labores indispensables y esenciales" en el ejercicio del derecho de huelga en el servicio civil, que fuera introducidos por el artículo 45.2 de la misma Ley. Los servicios esenciales también se regulan en la Ley de Relaciones Colectivas de Trabajo, que se aplica supletoriamente a ésta, tal como lo manda el segundo párrafo del artículo 40 de la Ley del Servicio Civil.

\section{Labores indispensables}

La norma reglamentaria establece que se exceptúa de la interrupción del servicio aquellas labores indispensables para la entidad, cuya paralización ponga en peligro a las personas, la seguridad, la conservación de los bienes o impida la reanudación inmediata de la actividad ordinaria de la entidad pública una vez concluida la huelga.

\section{Los servicios esenciales}

De igual modo, cuando la huelga afecte los servicios esenciales, se deberá garantizar la permanencia del personal necesario para impedir su interrupción total y asegurar su continuidad. Se entiende por tales servicios aquellos cuya interrupción ponen en peligro la vida, la seguridad o la salud de la persona en todo o parte de la población.

\footnotetext{
${ }^{10}$ Así lo establece el artículo 61 y 62 del TUO de la Ley de Relaciones Colectivas de Trabajo

${ }^{11}$ Así lo establece el artículo 74 del Reglamento de la Ley 30057 "De no llegarse a acuerdo en la etapa de conciliación, cualquiera de las partes podrá requerir el inicio de un proceso arbitral potestativo que formará parte del proceso de negociación colectiva."
} 
Los servicios esenciales son:

a) Los establecidos en el artículo 83 del Texto Único Ordenado de la Ley de Relaciones Colectivas de Trabajo, aprobado mediante Decreto Supremo 010-2003-TR; y

b) Los casos en los que se produzca una huelga en una actividad no calificada como servicio esencial, pero que por su prolongación en el tiempo pone en peligro la vida, seguridad o salud de toda o parte de la población.

Los servicios esenciales para la legislación peruana

Para efectos de huelga el TUO de la LRCT ha establecido cuáles son los servicios públicos esenciales:

a) Los sanitarios y de salubridad.

b) Los de limpieza y saneamiento.

c) Los de electricidad, agua y desagüe, gas y combustible.

d) Los de sepelio, y los de inhumaciones y necropsias.

e) Los de establecimientos penales.

f) Los de comunicaciones y telecomunicaciones.

g) Los de transporte.

h) Los de naturaleza estratégica o que se vinculen con la defensa o seguridad nacional.

i) Los de administración de justicia por declaración de la Corte Suprema de Justicia de la República.

j) Otros que sean determinados por ley.

Para este efecto, anualmente las empresas que prestan estos servicios esenciales, comunicarán a sus trabajadores u organización sindical que los representa y a la autoridad administrativa de trabajo, el número de trabajadores necesarios para el mantenimiento de los servicios, los horarios y turnos que deban cumplir, así como la periodicidad en que deben producirse los respectivos reemplazos. 
La indicada comunicación tiene por objeto que los trabajadores u organización sindical que los represente, cumplan con proporcionar la nómina respectiva cuando se produzca la huelga.

Los trabajadores que sin causa justificada dejen de cumplir el servicio, serán sancionados de acuerdo a ley. (La LRCL, modificada por la Ley 27912, establecía que estos trabajadores incurrían en falta grave).

Los casos de divergencia sobre el número y la ocupación de los trabajadores que deben figurar en la relación señalada en este artículo, serán resueltos por la autoridad administrativa de trabajo.

De existir divergencia sobre el número y la ocupación de los trabajadores que deben seguir laborando durante la huelga en el caso del Art. $82^{\circ}$ de la ley, será resuelta por la Autoridad de Trabajo en el caso de los trabajadores del Régimen Laboral Privado y por el Consejo de Apoyo al Servicio Civil (CASC) en caso de servidores de la administración pública

Deber de continuidad de servicios indispensables y servicios esenciales

En los casos en que la huelga afecte servicios indispensables o servicios esenciales, los servidores civiles en conflicto deberán garantizar la permanencia del personal necesario para que atienda los servicios mínimos de los servicios indispensables y/o de los servicios esenciales.

Anualmente, las entidades que presten servicios esenciales comunicaran a sus servidores civiles u organización sindical que los represente, el número, ocupación y horarios de servidores necesarios para el mantenimiento de los servicios mencionados.

En el caso que los servidores civiles no atendieran adecuadamente los servicios mínimos de los servicios indispensables y/o de los servicios esenciales, las entidades podrán contratar temporalmente el reemplazo de dicho personal de acuerdo a lo establecido en el numeral 45.2 del artículo 45 de la Ley.

En la figura siguiente se grafica el procedimiento para el ejercicio del derecho de huelga en el servicio civil.

Figura 4.3:

Flujograma de la procedencia y legalidad de la huelga en el Servicio Civil 


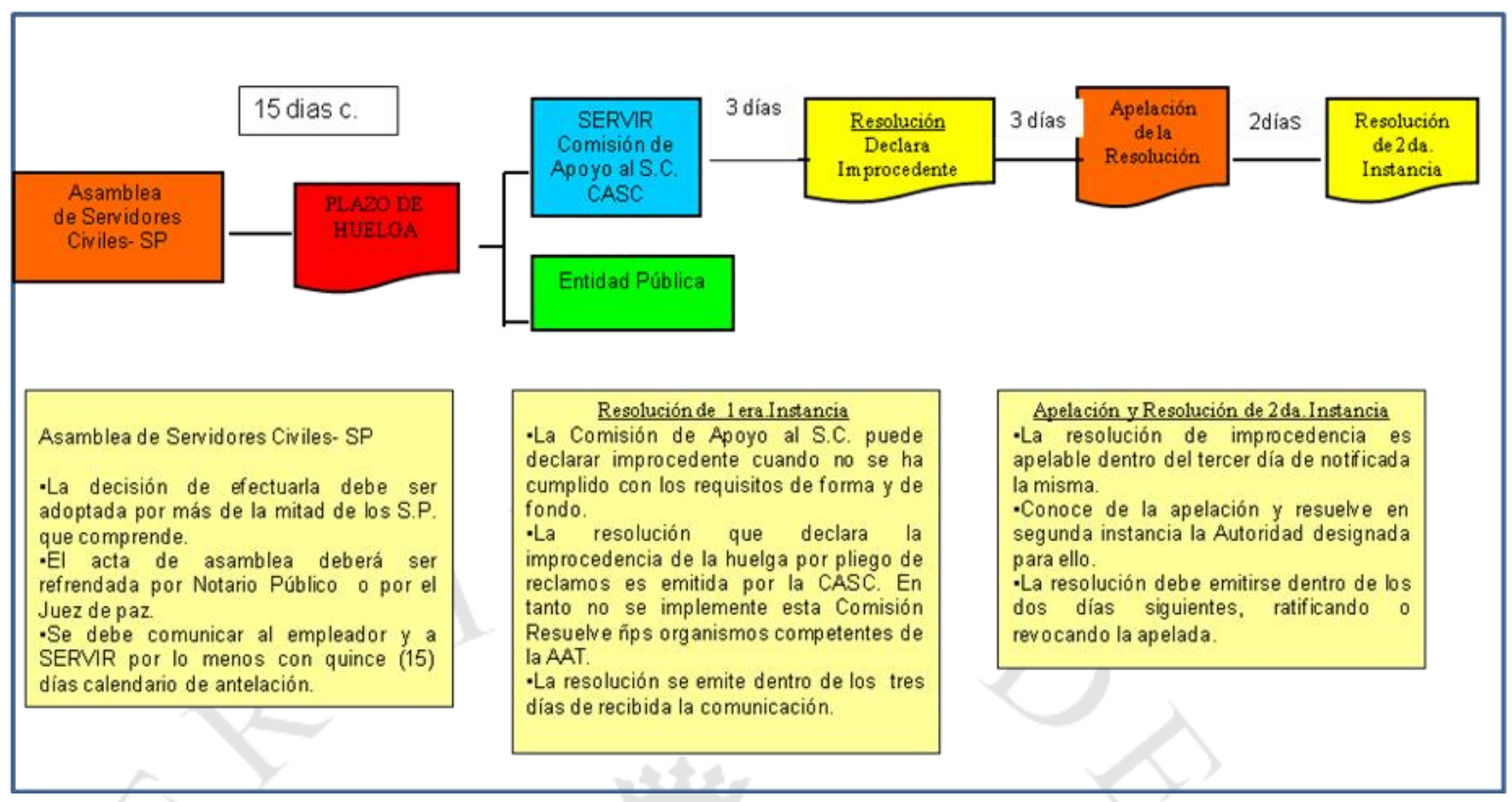

Fuente: Elaboración propia teniendo como base la Ley 30057 y su Reglamento.

Impacto de la Ley 30057 y su reglamento en el derecho de huelga de los servidores públicos. ¿Se reduce el derecho de huelga en el servicio civil?

Analizando la normativa del derecho de huelga en el TUO de la LRCT y comparándola con lo establecido en la Ley 30057 y su Reglamento podemos afirmar que este derecho se relativiza en gran parte y que prácticamente la hace inoperativa, tal como lo observamos en la tabla siguiente.

Tabla 4.3.

Comparativo del derecho de huelga en el régimen laboral privado y en el servicio público

Régimen Laboral privado (TUO de la LRCT- D.S 010-2003-TR y su Reglamento)

\section{Régimen del Servicio Civil (Ley 30057 y su Reglamento General)}

\begin{abstract}
Artículo 73
.- Para la declaración de huelga se requiere: (...)

c) Que sea comunicada al empleador y a la Autoridad de Trabajo, por lo menos con cinco (5) días útiles de antelación o con diez (10) tratándose de servicios públicos esenciales, acompañando copia del acta de votación.

\section{Art. 45. Ejercicio de la huelga}

45.1 El derecho de huelga se ejerce una vez agotados los mecanismos de negociación o mediación. Para tal efecto, los representantes del personal deben notificar a la entidad sobre el ejercicio del citado derecho con una anticipación no menor a quince (15) días. Es ilegal el ejercicio del derecho de huelga que no haya cumplido con lo establecido en el presente artículo.
\end{abstract}

\footnotetext{
DECRETO SUPREMO $\quad \mathrm{N}^{\mathrm{o}}$ 011-92-TR 45.2 El ejercicio del derecho de huelga permite a la (reglamento de la LRCT). entidad pública la contratación temporal y directa del personal necesario para garantizar la prestación de los

Artículo 70 servicios mínimos de los servicios esenciales y mínimos
} 
Cuando la huelga sea declarada observando los requisitos legales de fondo y forma establecidos por la Ley, todos los trabajadores comprendidos en el respectivo ámbito,

deberán abstenerse de laborar, y por lo tanto, el empleador no podrá contratar personal de reemplazo para realizar las actividades de los trabajadores en huelga. (...).

Artículo 61

-- Si no se hubiese llegado a un acuerdo en negociación directa o en conciliación, de haberla solicitado los trabajadores, podrán las partes someter el diferendo a arbitraje. de los servicios indispensables para el funcionamiento de la entidad, desde el inicio de la huelga y hasta su efectiva culminación.

Reglamento General Artículo 74. Arbitraje.

De no llegarse a acuerdo en la etapa de conciliación, cualquiera de las partes podrá requerir el inicio de un proceso arbitral potestativo, que formara parte del proceso de negociación colectiva, salvo que los trabajadores decidan irse a la huelga. (...).

\footnotetext{
Artículo 62

-- En el caso del artículo anterior, los trabajadores pueden alternativamente, declarar la huelga conforme a las reglas del artículo 73 . (...).

Artículo 73

-- Para la declaración de huelga se requiere:

$(\ldots)$

d) Que la negociación colectiva no haya sido sometida a arbitraje-
}

Art. 80 del Reglamento General-. Requisitos para la declaratoria de huelga

f) Que la negociación colectiva no haya sido sometida a arbitraje.

Fuente: Ley de Relaciones colectivas de Trabajo y Ley del Servicio Civil y sus respectivos reglamentos.

\section{El procedimiento de la Negociación Colectiva en el régimen del Servicio Civil se grafica en la siguiente figura:}

Figura 4.4.

Flujograma de la Negociación Colectiva en el Servicio Civil 


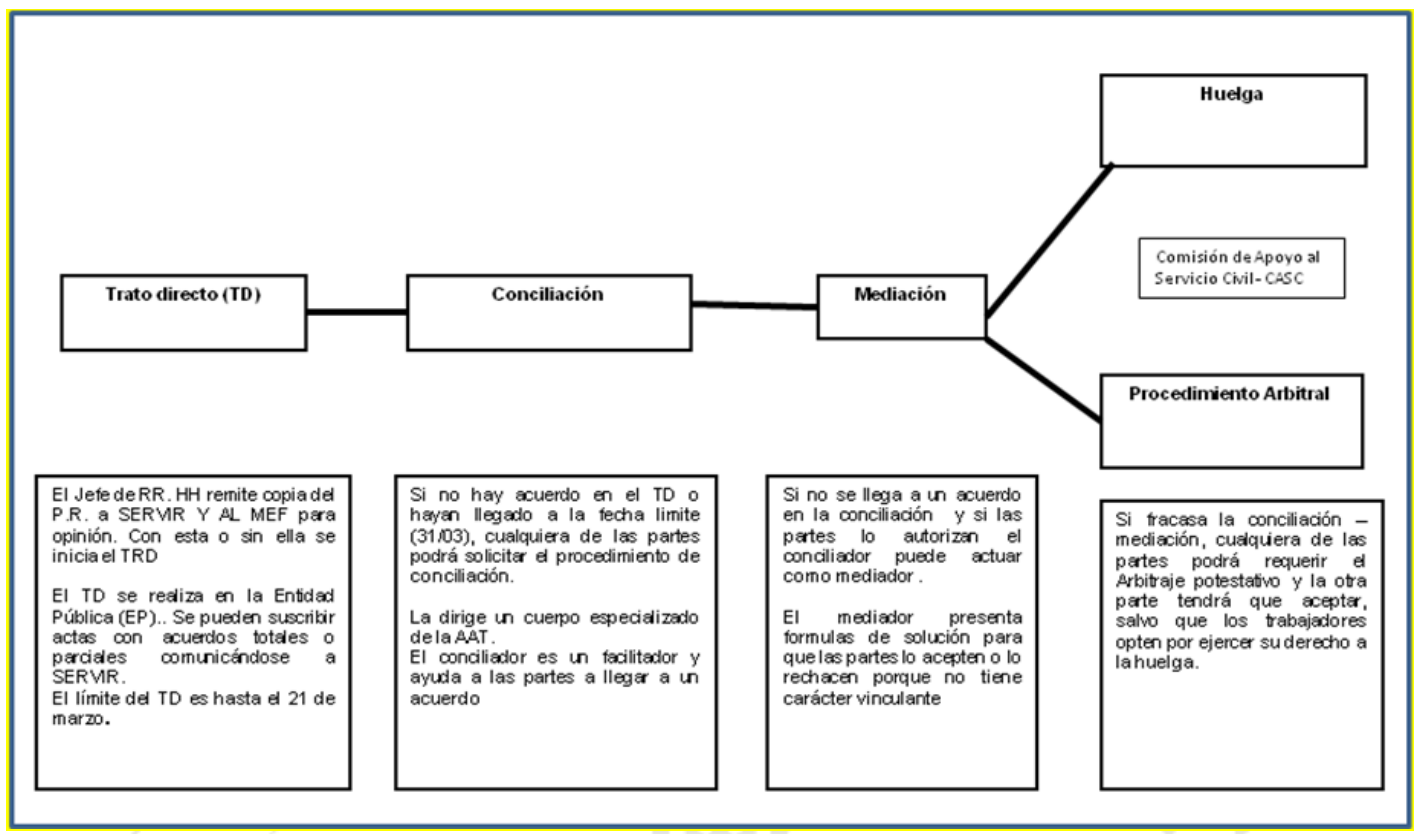

Fuente: Elaboración propia sobre la base de las normas legales y reglamentarias pertinentes.

\subsubsection{Diferencias entre la negociación colectiva en el régimen de la actividad} privada y en el régimen del Servicio Civil

4.4.4.1. Un nuevo actor en el procedimiento en el procedimiento de negociación colectiva en la Ley de Servicio Civil: La Comisión de Apoyo al Servicio Civil - CASC

Pocos se ha percatado que el Capítulo IV del Reglamento General de la Ley del Servicio Civil en su artículo 86 ha hecho su aparición, por lo menos en la vía normativa, de un nuevo actor: La Comisión de Apoyo al Servicio Civil.

La Comisión de Apoyo al Servicio Civil es el órgano facultado para conocer y resolver en primera y única instancia administrativa, los conflictos y controversias que, dentro del ámbito de su competencia, surjan entre organizaciones sindicales y entidades públicas o entre estas y los servidores civiles.

Los miembros de la Comisión son profesionales independientes, no pueden ser servidores civiles al momento de la designación y son especialistas en derecho administrativo, constitucional o laboral.

Esta Comisión se encuentra adscrita a la Autoridad Nacional del Servicio Civil - SERVIR, y, por lo tanto, a la Presidencia del Consejo de Ministros. 
Se encuentra conformada por tres (03) miembros titulares designados mediante resolución del Consejo Directivo de SERVIR para resolver las controversias que se le presenten. En dicha resolución, se designará, además, a dos miembros suplentes, quienes remplazarán a los miembros titulares en caso de ausencia.

\section{Competencias de la Comisión de Apoyo al Servicio Civil}

La Comisión es competente para resolver las siguientes materias:

a) Elección del presidente del tribunal arbitral.

b) Improcedencia e ilegalidad de la huelga.

c) En caso de controversia, determinar los servicios mínimos de los servicios indispensables y de los servicios esenciales.

¿Por qué no funciona la Comisión de Apoyo al Servicio Civil?

A la fecha este órgano adscrito a la Autoridad Nacional del Servicio Civil no se ha implementado por diversas razones, entre ellas la financiera. Pero de acuerdo a la Décima Complementaria Transitoria del Reglamento General de la Ley del Servicio Civil, sus competencias deben ser realizadas por el órgano competente del Ministerio de Trabajo y Promoción del Empleo.

\subsubsection{Limites a los plazos por razones de orden presupuestal}

Los tiempos en los plazos del procedimiento de la negociación colectiva se encuentran sujetos a las normas presupuestales de la República, establecidas en la Constitución Política del Estado y en la Ley General del Sistema Nacional del Presupuesto, Ley 28411.

En efecto La Constitución Política en su artículo 77 establece que la administración económica y financiera del Estado se rige por el presupuesto que anualmente aprueba el Congreso. Y el presupuesto asigna equitativamente los recursos públicos, su programación y ejecución responden a criterios de eficiencia, de necesidades sociales básicas y de descentralización. El artículo 26.2 de la Ley 28411 Ley General del Sistema Nacional de Presupuesto señala que las disposiciones legales y reglamentarias, los actos administrativos y de administración, los contratos y/o 
convenios así como cualquier actuación de las entidades que afecten gasto público deben supeditarse, de forma estricta a los créditos presupuestarios autorizados, quedando prohibido que dichos actos condicionen su aplicación a créditos presupuestarios mayores o adicionales a los establecidos en los presupuestos, bajo sanción de nulidad y responsabilidad del titular de la entidad y de la persona que autoriza el gasto.

De igual manera, el artículo 78 de la Constitución Política del Estado señala la obligación que tiene el Poder Ejecutivo de presentar al Congreso el Proyecto de Ley del Presupuesto General de la República hasta el 30 de Agosto de todos los años. Finalmente, el artículo 80 establece que la autógrafa de Ley de Presupuesto debe ser remitida al Poder Ejecutivo, a más tardar, el 30 de noviembre del mismo año, bajo apercibimiento de promulgarse el proyecto de presupuesto remitido por el Epoder Ejecutivo.

En razón de lo antes mencionado la Ley 30057, Ley del Servicio Civil ha establecido que los pliegos de reclamos de los servidores públicos o sus organizaciones sindicales deben ser presentados entre el 1 de Noviembre y el 30 de Enero del año siguiente y el plazo de negociación debe culminar como máximo el 15 de Junio del mismo año bajo sanción de que el mismo rija para el periodo anual subsiguiente.

Estas limitaciones de plazos no se observa en la negociación colectiva del régimen laboral privado

\subsubsection{Los servicio indispensables adicionales a los servicios esenciales.}

Una nueva categoría conceptual ha hecho su aparición en el procedimiento de Negociación Colectiva del Servicio Civil nos referimos a las "labores indispensables" la que se ha adicionado al término de servicios esenciales que ya se aplicaba en el régimen laboral privado.

El término de "labores indispensables" se encuentra desarrollado en el artículo 83 del Reglamento General de la Ley 30057 Ley del Servicio Civil, que fuera introducido por el artículo 45.2 de la misma Ley,

De acuerdo a la normatividad antes mencionada los servicios indispensables son aquellas labores cuya paralización ponga en peligro a las personas, a la seguridad y la 
conservación de los bienes o impida la reanudación inmediata de la actividad ordinaria de la entidad pública una vez concluida la huelga.

Al igual que los servicios esenciales, en caso en que la huelga afecte los servicios indispensables, los servidores civiles en conflicto deberán garantizar la permanencia del personal para que atiendan los servicios mínimos de los servicios indispensables, para lo cual las entidades públicas deberán comunicar a sus servidores civiles u organización sindical que los represente el número, ocupación y horarios de servidores necesarios para el mantenimiento de los servicios mencionados.

Consideramos que este nuevo concepto es una ampliación indirecta de los servicios esenciales y que por lo tanto relativizará el derecho de huelga de los servidores públicos.

\subsubsection{Facultad de contratación de personal de las entidades en casos de huelga en la administración pública}

En el caso del procedimiento de la Negociación Colectiva en el régimen del Servicio Civil se ha facultado a las entidades públicas a contratar en forma temporal y directa para garantizar la prestación de los servicios mínimos de los servicios esenciales y mínimos de los servicios indispensables para el funcionamiento de la entidad, desde el inicio de la huelga hasta su efectiva culminación. (Artículo 45.2 de la Ley 30057).

Tal facultad no se encuentra considerada en el régimen laboral privado es más se encuentra prohibida tal como se señala en el artículo 70 del Reglamento de la Ley de Negociaciones Colectivas de Trabajo del Decreto Supremo 011-TR el mismo que señala lo siguiente:

"Cuando la huelga sea declarada observando los requisitos legales de fondo y forma establecidos por la Ley, todos los trabajadores comprendidos en el respectivo ámbito, deberán abstenerse de laborar, y por lo tanto el empleador no podrá contratar personal de reemplazo para realizar las actividades de los trabajadores en huelga. (...).

Consideramos que dicha facultad afecta y relativiza el derecho de huelga de los servidores públicos pero que tendría su justificación en la necesidad de mantener los servicios mínimos indispensables y esenciales que podría afectar a la ciudadanía en general. 


\section{CAPÍTULO 5: LAS CONDICIONES ECONÓMICAS EN LA NEGOCIACIÓN COLECTIVA DE LA ADMINISTRACIÓN PÚBLICA}

\subsection{Nuevos Parámetros de Negociación: Condiciones de Empleo y los fundamentos que lo sustentan.}

Para poder desarrollar el tema de condiciones de empleo debemos partir por lo asignado en la Ley de Servicio Civil, en su Tercera Disposición Complementaria Final:

\section{TERCERA DISPOSICIÓN COMPLEMENTARIA FINAL}

Derechos colectivos del régimen del Decreto Legislativo 728

Los derechos colectivos de quienes prestan servicios al Estado bajo el régimen del Decreto Legislativo 728 se interpretan de conformidad con las disposiciones del Convenio 151 de la OÍT. Esta disposición rige a partir del día siguiente de la publicación de la presente Ley.

Respecto al Convenio OIT 151 se señala lo siguiente:

\section{Convenio 151 de la OIT:}

Artículo $7^{\circ}$.- Deberán adoptarse, de ser necesario, medidas adecuadas a las condiciones nacionales para estimular y fomentar el pleno desarrollo y utilización de procedimientos de negociación entre las autoridades públicas competentes y las organizaciones de empleados públicos acerca de las condiciones de empleo, o de cualesquiera otros métodos que permitan a los representantes de los empleados públicos participar en la determinación de dichas condiciones.

A efectos de la presente Ley y de conformidad al Convenio 151 de la OIT se debe entender como Condiciones de trabajo o condiciones de empleo a los permisos, licencias, local sindical, capacitación, uniformes, ambiente de trabajo y, en general, todas aquellas que faciliten la actividad del servidor civil para el cumplimiento de sus funciones. 
En ese sentido únicamente podrían ingresar dentro de la negociación colectiva condiciones de empleo, y no se debe aplicar en ninguno de los casos cuestiones remunerativas, por lo que sería nulas de pleno derecho.

\subsection{Inconsistencias observadas en la Ley 30057, Ley del Servicio Civil relacionadas con la Negociación Colectiva.}

Como ya lo hemos mencionado a lo largo de la investigación la Ley del Servicio Civil, adolece de innumerables inconsistencias con la Constitución y con los tratados internacionales. Entre ellas podemos mencionar:

A.- El artículo 31.2, que establece que las compensaciones económicas no son materia de negociación.

B.- El artículo $40^{\circ}$, que establece que ninguna negociación colectiva puede alterar la valorización de puestos de la ley.

C.- El artículo $42^{\circ}$, que sólo permite a los servidores civiles solicitar la mejora de sus compensaciones no económicas.

D.- El artículo $43^{\circ}$, que señala que el pliego que da inicio a la negociación colectiva sólo puede contener peticiones respecto a condiciones de trabajo; y,

El artículo $44^{\circ}$, que establece que las propuestas de la entidad pública relativas a compensaciones económicas son nulas de pleno derecho, y que también son nulos los acuerdos adoptados en violación de dicho artículo.

En esta materia el Estado empleador, dentro de la teoría estatutaria, ha establecido "reglas de juego a su favor" trasgrediendo lo expresamente señalado en el artículo $28^{\circ}$ de la Constitución que reconoce los derechos de sindicación, negociación colectiva y huelga, que están ubicados dentro del Título I, "De la persona y de la sociedad", aplicable a todos los ciudadanos peruanos que trabajan.

Esta garantía constitucional de la negociación colectiva impone la obligación al Estado de fomentarla como parte de la promoción de formas de solución pacífica de los conflictos laborales.

La Ley del Servicio Civil sólo reconoce una parte de la negociación colectiva, respecto a las condiciones de trabajo), mientras que prohíbe la otra parte sustancial de la 
negociación colectiva que son las condiciones económicas, vaciando de contenido el fundamental derecho a la negociación colectiva de los servidores públicos del país ${ }^{12}$.

\subsection{Puntos de vista de juristas $\mathbf{y}$ docentes universitarios $y$ entidades públicas relacionadas al tema}

La pugna entre los seguidores de la teoría contractualista y estatutaria en materia de negociación colectiva ha sido constante. Hemos recopilado las siguientes posiciones:

\subsubsection{Argumentos a favor de la negociación Colectiva de los servidores públicos}

A. El distinguido jurista Acevedo Mercado, miembro de la Comisión Consultiva de la Comisión de Trabajo del Congreso de la República, se refirió al derecho de la Negociación Colectiva de los Servidores Públicos en los siguientes términos ${ }^{13}$ :

1. "La titularidad de los derechos fundamentales vinculados a la libertad sindical a favor de los trabajadores estatales no ha estado exenta de polémica a nivel doctrinario. En efecto, por un lado, los representantes del unilateralismo tradicional negaban el ejercicio de tales derechos a favor de los servidores públicos bajo el argumento de que el Estado tiene el derecho a determinar en forma unilateral las remuneraciones de los servidores públicos por ser el representante de la voluntad popular (o de los intereses generales)."

2. Actualmente, dicha posición ha sido superada. En efecto, de acuerdo a la Cuarta Disposición Final y Transitoria de la Constitución, los alcances de los derechos fundamentales deben interpretarse en atención a lo establecido en los tratados internacionales de derechos humanos ratificados por el Perú. Por tal motivo, a efectos de determinar la titularidad del referido derecho, es necesario considerar lo dispuesto en los Convenios No. 87, 98 y 151 de la OIT.

3. Los referidos Convenios comprenden en su ámbito de aplicación a los trabajadores tanto privados como públicos, excluyendo únicamente a los

\footnotetext{
${ }^{12}$ El Tribunal Constitucional a través de su Sentencia recaída en el Exp. 0025-2013-PI/TC declaró inconstitucional estas normas.

${ }^{13}$ Informe del 09 de mayo de 2013 a la Comisión de Trabajo respecto al Proyecto de Ley del Servicio

Civil en su calidad de Miembro Consultor de la Comisión de Trabajo del Congreso de la República.
} 
sujetos que han sido señalados en el artículo $42^{\circ}$ de nuestra Constitución. En el mismo sentido, se ha pronunciado el Tribunal Constitucional:

(...) en ese sentido, la Constitución reconoce en su artículo $42^{\circ}$ el derecho de sindicación de los servidores públicos. Consecuentemente, las organizaciones sindicales de los servidores públicos serán titulares del derecho a la negociación colectiva, con las excepciones que establece el mismo artículo, a saber los funciones del Estado con poder de decisión, los que desempeñan cargos de confianza o de dirección, y los miembros de las Fuerzas Armadas y de la Policía Nacional.

4. Tal criterio es compartido por la Comisión de Expertos en Aplicación de Convenios y Recomendaciones de la OIT por cuanto considera que el derecho a la libertad sindical se encuentra integrado por una faceta orgánica, una faceta dinámica a la negociación colectiva y por cualquier otra actividad relacionada con la defensa de los intereses de sus miembros.

5. Por ello, podemos concluir que aquellas personas que prestan servicios bajo una relación de subordinación y dependencia son titulares de todos los derechos constitucionales laborales, incluidos los de libertad sindical, negociación colectiva y huelga consagrados en el artículo $28^{\circ}$ del referido cuerpo normativo, independientemente de la naturaleza pública o privada de sus empleadores.

B.- El profesor Balbín Torres (2005, p. 180) señala que

La superación de las objeciones dogmáticas al derecho de negociación colectiva de los trabajadores públicos tiene por objeto la reafirmación de la centralidad del derecho para la implantación de una efectiva libertad sindical y para el sistema de relaciones laborales en su conjunto. Sin embargo, no significa necesariamente que la regulación del derecho de negociación colectiva pueda o deba ser la misma que en el sector privado.

Por el contrario, la innegable especialidad de la relación de empleo público fundada en el influjo de interés público sobre localizados segmentos de la relación de empleo nos conduce a la conformación de un ejercicio particularizado del derecho (...). 
C.- El profesor Adolfo Ciudad Reynaud (2016), al comentar sobre la Ley del Servicio Civil ha expresado que:

En efecto, la negociación colectiva es uno de los cuatro principios y derechos fundamentales en el trabajo junto con la libertad sindical. En junio de 1998, la OIT adoptó por acuerdo tripartito de todos sus constituyentes (todos los gobiernos y representantes de empleadores y trabajadores del mundo), la Declaración relativa a los principios y derechos fundamentales en el trabajo y su seguimiento. Estos principios, entre otros, incluyen el reconocimiento efectivo del derecho de negociación colectiva, que deben ser respetados con independencia de la ratificación o no de los ocho convenios fundamentales.

La titularidad del derecho a la negociación colectiva de los trabajadores públicos goza de amplia jurisprudencia consolidada en la doctrina del Tribunal Constitucional. Por ejemplo, en la Sentencia recaída en el Exp. 008-2005-PI/TC, demanda de inconstitucionalidad presentada contra diversos artículos de la Ley $\mathrm{N}^{\circ} 28175$, Marco del Empleo Público, en el fundamento 29 ha definido al convenio colectivo:

"como el acuerdo que permite crear, modificar o extinguir derechos $\mathrm{y}$ obligaciones referidas a remuneraciones, condiciones de trabajo, productividad y demás aspectos concernientes a las relaciones laborales. (...)"

\section{D.- Posición de la Dirección General de Trabajo del MTPE}

La Dirección General de Trabajo del Ministerio de Trabajo y Promoción del Empleo ante un requerimiento de la OIT, presentó un informe ${ }^{14}$ en la que sostenía que el derecho de la negociación colectiva de los servidores públicos tenía sustento constitucional y que tenía que ser promovido por el Estado.

En una de sus conclusiones señala que

La opinión técnica que nos fue solicitada con ocasión de la información que el Estado Peruano debe entregar al Comité de Administración de la OIT ha sido la oportunidad de advertir algunos problemas relativos a la vigencia del derecho de libertad sindical (En general) y de la negociación colectiva (En específico) dentro de las relaciones de trabajo estatales. Así, es opinión de esta Dirección General de Trabajo que el convenio

14 Informe de la Dirección General de Trabajo N 05-2012-MTPE/2/14, del 13 de enero de 2012 en respuesta al requerimiento de la Dirección de Normas Internacionales de la OIT acerca de la presentación de memorias sobre el Convenio 154 y la recomendación 163. Ver Anexo $\mathrm{N}^{\circ}$ 
sobre la negociación colectiva ( $\mathrm{N}^{\circ} 154$ de la OIT) de 1981 debería ser ratificado. A lo largo de este informe hemos advertido que ningún fundamento jurídico puede sustentar, a la luz de la constitución y las normas internacionales, la opinión según la cual a los trabajadores estatales no les corresponde el derecho de negociación colectiva. Al contrario, el sustento constitucional e internacional de este derecho para dichos trabajadores es evidente y su eficacia resulta absolutamente indispensable dentro de un sistema de relaciones laborales que se precie de democrático.

En esa línea de pensamiento, tras la ratificación del Convenio 154 de la OIT y la adecuación de la legislación nacional en sus preceptos, creemos que es imperativo que la Autoridad Administrativa de Trabajo adopte una perspectiva amplia del derecho fundamental de libertad sindical y del derecho de negociación colectiva, específicamente dentro de su intervención en las relaciones laborales. Solamente ello asegurará que en todas sus instancias se produzcan actuaciones conforme con la Constitución, la normativa constitucional aplicable y la legislación laboral. (...)

Este documento, a lo largo de su exposición, también resalta la importancia de la aplicación del arbitraje potestativo en la negociación colectiva tanto para el régimen laboral público como para el privado.

Tratándose de un documento oficial emitido por la Autoridad Administrativa de Trabajo que velar por la política laboral del país debemos tomarlo en cuenta para interpretar y aplicar los derechos fundamentales de los servidores públicos.

E.- Posición de los Magistrados Mesía Ramírez, Vergara Gotelli y Calle Hayen en la sentencia recaída en el Exp. 00018-2013-PI/TC.

Estos Magistrados, en una clara posición contractualista expresaron en dicha Sentencia que todas las limitaciones a la Negociación Colectiva en el Empleo Público establecidas en la Ley del Servicio Civil eran inconstitucionales. Se basaban en los siguientes fundamentos:

- El derecho de negociación colectiva de los servidores públicos es un derecho fundamental reconocido en el artículo 28 de la Constitución. El hecho de que el artículo 42 no lo considere literalmente no implica que no sea aplicable para ellos. 
- La titularidad del derecho a la negociación colectiva de los servidores públicos es una tesis consolidada en la jurisprudencia del Tribunal Constitucional, pues con ocasión de la demanda de inconstitucionalidad presentada contra diversos artículos de la Ley 28175, Marco del Empleo Público (Exp. Nº008-2005-P1/TC15), así se le consideró.

- El derecho a la negociación colectiva debe ser tutelado desde la Constitución y los Convenios de la OIT. Su ejercicio está vinculado al ejercicio del derecho de huelga, y ambos, cuando se trata de servidores públicos, están inescindiblemente relacionados con el ejercicio del derecho de sindicación; por lo que prohibir a servidores públicos el negociar beneficios económicos, importa afectar directamente su contenido esencial y priva a las organizaciones sindicales de un "instrumento" que les permita exigir mejoras remunerativas para sus asociados.

- Respecto a las limitaciones a la negociación colectiva basadas en los principios presupuestales, han considerado que es inconstitucional limitar el ejercicio de este derecho, en tanto que desnaturaliza su contenido al prever que solo se pueden negociar reclamos vinculados a compensaciones no económicas, así como a las posibilidades presupuestarias y de infraestructura de la entidad; para ello este grupo de magistrados en su Fundamento 14, se sustentan en la STC recaída en el Exp. $\mathrm{N}^{\circ}$ 00008-2005-PI/TC, (que por error material ponen como año $2010^{16}$ ) que estableció;

53. Dicho Convenio (151 de la OIT) establece en su artículo $7^{\circ}$ que deberán adoptarse, de ser necesario, medidas adecuadas a las condiciones nacionales para estimular y fomentar el pleno desarrollo y utilización de procedimientos de negociación entre las autoridades públicas competentes y las organizaciones de empleados públicos en torno a las condiciones de empleo, o de cualesquiera otros métodos que permitan a los representantes de los empleados públicos participar en la determinación de dichas condiciones.

(...). 54. Por otro lado, una negociación colectiva en el ámbito laboral implica

${ }^{15}$ STC recaída en el Exp. 00008-2005-PI/TC. Juan José Gorriti y más de 5,000 ciudadanos vs Congreso de la República, inconstitucionalidad de la Ley 28175, Ley Marco del Empleo Público.

${ }^{16}$ Véase el fundamento 14 del voto del segundo grupo de magistrados, séptimo párrafo. 
contraponer posiciones, negociar y llegar a un acuerdo real que ambas partes puedan cumplir. En tal sentido, no porque la ley disponga que todo acto relativo al emplea público que tenga incidencia presupuestaria debe estar debidamente autorizado y presupuestado se vulnera el derecho a la negociación colectiva y a la libertad sindical.

En efecto, precisamente después de los acuerdos logrados mediante la negociación colectiva, conforme a la legislación vigente para los servidores público, los que tengan incidencia económica se podrán autorizar y programar en el presupuesto (... )

Por ello consideran que es posible realizar una negociación colectiva aun cuando el objetivo de aquella incida en el presupuesto institucional de la entidad a la que pertenece el sindicato; sin embargo, este no deja de constituir un límite pero para el resultado de la negociación y no para aquella en sí misma, en tanto derecho de los servidores públicos sindicalizados, por lo que las referidas prohibiciones resultan inconstitucionales.

F.- De otro lado, considero de gran importancia académica y política la declaración Pública denominada LEY DE PRESUPUESTO: DESCONOCIMIENTO DE DERECHOS LABORALES Y DEL FUERO ARBITRAL ${ }^{17}$, suscrita por importantes laboralistas entre las que destacan la de los ex ministros de Trabajo y Promoción del Empleo: Carlos Blancas Bustamante, Javier Néves Mujica, Jorge Villasante Aranibar, que consideran que las restricciones a la negociación colectiva en la administración pública y al fuero arbitral establecido colisionan con la Constitución Política. Así, el documento expresa:

Estas disposiciones resultan inconstitucionales por las siguientes razones: La prohibición de incrementos salariales vulnera el derecho de negociación colectiva reconocido en el artículo 28 de nuestra Constitución, toda vez que como el propio Tribunal Constitucional ha señalado: la Constitución reconoce en su artículo $42^{\circ}$ el derecho de sindicación de los servidores públicos. Consecuentemente, las organizaciones sindicales de los servidores públicos serán titulares del derecho a la negociación colectiva, con las excepciones que establece el mismo artículo $42^{\circ}$, a saber los funcionarios del

\footnotetext{
17 Véase la declaración pública publicada en diferentes medios de comunicación, entre ellos La República" del domingo 27 de enero de 2013.
} 
Estado con poder de decisión, los que desempeñan cargos de confianza a do dirección, y los miembros de las Fuerzas Armadas y de la Policía Nacional". (Párrafo 52 de la Sentencia recaída en el Expediente $\mathrm{N}^{\circ}$ 008-2005-PI/TC).

El derecho constitucional a la negociación colectiva debe interpretarse conforme a los Convenios 87 y 98 OIT según los cuales, el derecho de negociación colectiva debe ejercerse de modo libre, voluntario y de buena fe. Por lo que, una prohibición sobre cualquier parte del proceso de negociación, sea negociación directa o sea arbitraje, debe considerarse contraria a la Constitución y a los mencionados instrumentos internacionales de derechos humanos.

La declaración de nulidad de los laudos arbitrales que incumplen la prohibición, así corno la inhabilitación de los árbitros que participan en los mismos, constituye una violación a la independencia de la jurisdicción arbitral (art.139.1 Constitución) y un atentado a la facultad arbitral de aplicar el control difuso como también lo ha reconocido explícitamente el Tribunal Constitucional (Sentencia recaída en el Expediente $\mathrm{N}^{\circ}$ 000142-2011- PA/TC).

Estos mandatos contenidos en la Ley de Presupuesto, a los que, además, inconstitucionalmente se les reconoce carácter permanente, contravienen también lo expuesto por el Comité de Libertad Sindical de OIT, que ha señalado en el Caso 2690 sobre Perú presentado en el año 2010 (Informe $N^{\circ} 357$ ), el mismo que señala.:

946., “...el Comité subraya que la imposibilidad de negociar aumentos salariales de manera permanente es contraria al principio de negociación libre y voluntaria consagrado en el Convenio núm. 98 y pide al Gobierno que promueva mecanismos idóneos para que las partes puedan concluir un convenio colectivo en un futuro próximo. El Comité pide al Gobierno que le mantenga informado al respecto.

En el mismo sentido se ha pronunciado la Corte Suprema de Justicia en la Ejecutoria Suprema de la Sala de Derecho Constitucional y Social Permanente (Apel. $N^{\circ}$ 24912011, de fecha 10 de noviembre de 2011):

DÉCIMO: (...)Este Colegiado considera que la disposición presupuestaria invocada por la recurrente que prohíbe efectuar incrementos y reajustes en las remuneraciones en los últimos cinco años en los tres niveles de gobierno, terminaría por desconocer el contenido esencial del derecho a la negociación colectiva, ya que se negaría de plano la posibilidad de mejorar las condiciones de vida y de trabajo de los 
destinatarios" que es precisamente larazón de ser de la negociación colectiva; con loque se infringiría la obligación del Estado de fomentar a través de la negociación colectiva y los medios alternativos de solución de conflictos, entre ellos el arbitraje, la resolución de los conflictos laborales existentes de manera definitiva, autónoma y vinculante.

Por estas consideraciones, solicitamos a los organismos encargados del control constitucional de las leyes inaplicar o derogar, según corresponda, los mencionados preceptos de esta Ley."

La Ley 30057, Ley del Servicio Civil en efecto considera a los derechos colectivos de trabajo, en especial a la negociación colectiva pero con una serie de restricciones las cuales han sido materia de comentarios y críticas respecto a la probable inconstitucionalidad de las mismas lo que ha originado varias acciones de inconstitucionalidad ante el Tribunal Constitucional.

\subsubsection{Argumentos en contra}

A. Entre quienes, de una u otra forma, se sitúan en la posición Estatutaria y no están de acuerdo en que la Negociación Colectiva de los Servidores Públicos relacionadas a Condiciones económicas se lleve a cabo, podemos mencionar a Morales Corrales (2008: p. 428).

El mencionado profesor se basa en los fundamentos de la Sentencia emitida por el Tribunal Constitucional recaído en el expediente 008-2005-PI/TC de fecha 12 de agosto de 2008 sobre la inconstitucionalidad de la Ley $\mathrm{N}^{\circ} 28175$ Ley Marco del Empleo Público, siendo ellas las siguientes:

a) Los servidores públicos tienen derecho a la negociación colectiva. Está comprendido en el derecho de sindicación que les reconoce el artículo 42 de la Carta Magna.

b) El artículo 42 de la Constitución debe ser interpretado a la luz del Convenio 151 de la OIT(Fundamento Jurídico 52)

c) Entre las "condiciones nacionales" a las que hace alusión el artículo 7 del Convenio 151 de la OIT como limitaciones a la negociación colectiva de los servidores públicos, están las normas relativas al presupuesto público, principalmente los artículos 77 y 78 de la carta 
Magna: el presupuesto asigna equitativamente los recursos públicos y su proyecto debe estar efectivamente equilibrado (Fundamento Jurídico 53)

d) La negociación colectiva de los servidores públicos debe considerar tales limitaciones, ya que las condiciones de empleo en la Administración Pública se financien con recursos de los contribuyentes y de la Nación (Fundamento Jurídico 53)

e) No porque la ley disponga que todo acto relativo al empleo público que tenga incidencia presupuestaria debe estar debidamente autorizado y presupuestado se vulnera el derecho a la negociación colectiva de los servidores públicos. Así, el principio de provisión presupuestal es plenamente constitucional y no atenta contra la negociación colectiva (Fundamento Jurídico 54)

En ese sentido Morales Corrales (2008) considera que la Negociación Colectiva de los Servidores Públicos no se encuentra sustentado en el artículo 28 de la Carta Magna ni en el Convenio 98 de la OIT, sino en el artículo 42 de la Constitución Política y el Convenio 151 de la OIT que permite limitar la negociación a condiciones de empleo, por consideraciones presupuestales y en aplicación del principio de "Provisión Presupuestaria" establecido en los artículos 77 y 78 de la Constitución.

B. Los magistrados del Tribunal Constitucional Urviola Hani, Eto Cruz y Álvarez Miranda, en la sentencia recaída en el Exp. 00018-2013-PI/TC, se pronunciaron en el sentido de que si era constitucional la prohibición de la negociación colectiva en materia de remuneraciones a los servidores civiles y sólo reconociendo el derecho de negociación para las condiciones de empleo, tal como lo establece el Convenio 151 de la OIT.

Su principal fundamento se basa en que no corresponde considerar dentro del bloque de constitucionalidad del derecho a la negociación colectiva establecida en el artículo 28 de la Constitución al Convenio $\mathrm{N}^{\circ} 154$ de la OIT al no haber sido ratificado por el Estado Peruano dicho instrumento internacional, rectificando parcialmente la 
STC, recaída en el Expediente $\mathrm{N}^{\circ}$ 2566-2012-PA/TC ${ }^{18}$ y en la STC, recaída en el Expediente $\mathrm{N}^{\circ} 3561-2009-\mathrm{PA} / \mathrm{TC}^{19}$. (Fundamento 57).

De ello se valen principalmente para establecer que no correspondería la negociación colectiva en materia de remuneraciones a los servidores públicos cuando mencionan en su fundamento 67 y 68 lo siguiente:

Si el Perú hubiese ratificado el Convenio 154 de la OIT, la obligación sería distinta, toda vez que la comunidad internacional reconoció en el que la negociación colectiva constituye el medio privilegiado para reglamentar las condiciones de trabajo tanto para el sector público como para el sector privado (artículo 2), reiterando la posibilidad de que los Estados parte adopten la implementación de dicho mecanismo a sus circunstancias particulares (artículos 1.3 y 5.1). Este criterio ha sido desarrollado en el párrafo $50 \quad$ del mencionado Informe de la CEACR, en cuanto establece que el Estado Miembro que haya ratificado el Convenio 154 "no puede, en consecuencia, seguir limitándose al método de consulta, como sucedía con el Convenio num. 151, y debe promover la negociación colectiva de las condiciones de trabajo y empleo".

También consideran de gran importancia el Principio de Equilibrio Presupuestal que está recogido en el Convenio 151 de la OIT y en los artículo 77 y 78 de la Constitución Política del Perú al establecer que: "El presupuesto asigna equitativamente los recursos públicos, su programación y ejecución responden a los criterios de eficiencia de necesidades sociales básicas y de descentralización ", y que "El proyecto presupuestal debe estar efectivamente equilibrado.

\section{Posición de la Autoridad Nacional del Servicio Civil}

De acuerdo a la documentación mostrada en la Comisión de Trabajo se observa el Informe N555-2010-SERVIR de la Autoridad Nacional del Servicio Civil en la que expresa sus puntos de vista en contra de que la Negociación Económica de los Servidores Públicos sea de carácter económico y/o remunerativa.

Este órgano rector del sistema de Recursos Humanos de la Administración Pública menciona que el Derecho Colectivo de los Servidores Públicos no tienen

\footnotetext{
${ }^{18}$ STC recaída en el Expediente $N^{\circ}$ 2566-2012-PA/TC, Demanda de amparo interpuesta por el Sindicato Nacional de Unidad de la SUNAT vs la SUNAT.

${ }^{19}$ STC recaída en el Expediente N ${ }^{\circ}$ 3561-2009-PA/TC, Demanda de amparo del Sindicato Único de Trabajadores Marítimos y Portuarios vs la Asociación de Operadores Portuarios y otros sobre continuación del procedimiento de negociación colectiva.
} 
fundamento Constitucional, ya que el artículo 42 de la Constitución no lo señala expresamente, y solo se refiere a la Sindicalización y al Derecho de Huelga. Con relación a las limitaciones a la Negociación Colectiva, se refirió conforme a lo siguiente:

De las limitaciones al derecho a la negociación colectiva en el sector público" Sobre este punto, reiteramos nuestros comentarios expresados en los informes legales $\mathrm{N}^{\circ} \mathrm{s} 149$ y 162-2009-SERVIR/GG-OAJ y 063, 181 y 213-2010-SERVIR/GG-OAJ, en el sentido que la Constitución y otras normas de menor jerarquía prevén que el ejercicio del derecho constitucional a negociación colectiva de los servidores públicos como cualquier otro derecho, no es absoluto, sino que está sujeto a determinados límites que son impuestos por la propia norma fundamental y otras disposiciones como las indicadas en los numerales precedentes.

Así, conforme a las normas relativas al presupuesto público previstas en el artículo 77 de la Constitución, las negociaciones colectivas de los servidores públicas deben efectuarse considerando el límite constitucional que impone un presupuesto equilibrado y equitativo que debe ser aprobado por el Congreso de la República, toda vez que las condiciones de trabajo en la administración pública se financian con los recursos de los contribuyentes. (...)

Los límites presupuestales se encuentran contenidos en el artículo 77 de la Constitución Política que establece:

Presupuesto Público, La administración económica y financiera del Estado se rige por el presupuesto que anualmente aprueba el Congreso. La estructura del presupuesto del sector público contiene dos secciones: Gobierno Central e instancias descentralizadas. El presupuesto asigna equitativamente los recursos públicos, su programación y ejecución responden a los criterios de eficiencia de necesidades sociales básicas y de descentralización. Corresponden a las respectivas circunscripciones, conforme a ley, recibir una participación adecuada del total de los ingresos y rentas obtenidos por el Estado en la explotación de los recursos naturales en cada zona en calidad de canon.

$\mathrm{Al}$ respecto, considero que se deben cumplir las limitaciones de carácter presupuestal en especial el que todo gasto considerado en la negociación colectiva debe estar presupuestado y debe responder a una distribución equitativa de los recursos públicos. Las limitaciones presupuestales no deben llegar al extremo de prohibir indefinidamente la negociación de remuneraciones en el sector público, sino que estas medidas 
limitativas de derechos de carácter presupuestal deben ser excepcionales y de carácter temporal.

\subsubsection{Punto de vista intermedio}

Después de analizar las dos posiciones, a favor y en contra, de las restricciones en la negociación colectiva en Sector Público, podemos apreciar que ambas concepciones tienen fundamentos doctrinarios, constitucionales y legales, a favor de sus puntos de vista. Sin embargo, considero que tiene mayor relevancia y fundamento constitucional la propuesta que permite una negociación libre de los servidores públicos, en la que se deben considerar como materia importante las remuneraciones y condiciones económicas.

Lo antes mencionado es corroborado con informes de diferentes instituciones nacionales e internacionales, como por ejemplo la OIT, quien se ha pronunciado en contra de la prohibición de negociar condiciones salariales a los organismos sindicales de la administración pública en el Peru. En efecto el Comité de Libertad Sindical de la OIT ha establecido criterios para determinar la validez de las restricciones a la negociación colectiva en los siguientes términos:

(...) El Comité señala, por otra parte, que en numerosas ocasiones ha indicado que «si en virtud de una política de estabilización un gobierno considerara que las tasas de salarios no pueden fijarse libremente por negociación colectiva, tal restricción debería aplicarse como medida de excepción, limitarse a lo necesario, no exceder de un período razonable e ir acompañada de garantías adecuadas para proteger el nivel de vida de los trabajadores ${ }^{20}$

Como se observa, la OIT considera que optar por una conducta diferente desnaturalizaría el contenido del derecho fundamental a la negociación colectiva. En nuestro caso, ésta desnaturalización sería por demás evidente, ya que la economía peruana, viene pasando por un proceso de crecimiento económico hace más de diez años.

De otro lado, también se han pronunciado la Defensoría del Pueblo, que ha expresado, en uno de sus informes dirigido a la Comisión de Trabajo del Congreso de la

${ }^{20}$ Informe 357 de la OIT apartado 944 
República ${ }^{21}$, que "si bien el derecho fundamental a la negociación colectiva debe tener en cuenta las cuestiones presupuestales, de ello no se deriva una prohibición absoluta de la posibilidad de negociar. Por el contrario, resulta necesario, que se adopten todas las medidas adecuadas para garantizar este derecho, incluso para futuros ejercicios presupuestales.

Finalmente coincide con este razonamiento el reciente fallo del Tribunal Constitucional recaído en los expedientes 005-2013-PI/TC y otros, de fecha 26 de abril de 2016, la cual será materia de análisis en el siguiente punto. Podemos concluir que la teoría contractualista de la relación estado servidor público se viene imponiendo a la teoría estatutaria, quien proponía la negociación colectiva con prohibiciones en materia económica. La concepción contractualista establece la vigencia de todos los derechos laborales a los servidores públicos en materia de negociación colectiva.

\subsection{Jurisprudencia del $\mathrm{TC}$ relacionadas al tema}

\subsubsection{STC del TC EX 00018-2013-PI/TC respecto a la inconstitucionalidad de la} Ley 30057

El 21 de mayo de 2014 se emitió la STC recaída en el Exp. 00018-2013-PI/TC, demanda de inconstitucionalidad contra diversos artículos de la Ley 30057, Ley del Servicio Civil, presentada por treinta y cuatro congresistas de la República. La sentencia está conformada por dos votos suscritos por tres magistrados cada uno, con sus propios fundamentos y fallos. Sólo coincidieron para declarar "fundada en parte" la demanda $\mathrm{y}$, en consecuencia, INCONSTITUCIONAL la expresión “o judicial” del segundo párrafo de la Cuarta Disposición Complementaria Transitoria (DCT) de la Ley 30057.

No habiéndose conseguido los votos suficientes, se presume que el resto de la Ley 30057 se encuentra de conformidad con la Constitución.

El primer grupo de magistrados coincide en que sí sería constitucional la prohibición de la negociación colectiva en materia de remuneraciones para los

\footnotetext{
${ }^{21}$ Oficio $N^{\circ}$ 0152-2014-DP del 16 de abril de 2014 dirigido al Presidente de la Comisión de Trabajo y Seguridad Social, adjuntando el Informe $\mathrm{N}^{\circ} 001-2014-D P / A A E$. Opinión sobre las restricciones a la Negociación Colectiva contenidas en la Ley N³0057.
} 
servidores civiles, a pesar de reconocer que el derecho constitucional a la negociación colectiva sí le corresponde tal como lo menciona en su fundamento.

Sin embargo establecen que no corresponde considerar dentro del bloque de constitucionalidad del derecho a la negociación colectiva establecida en el artículo 28 de la C. P. al Convenio 154 de la OIT al no haber sido ratificado por el Estado Peruano, rectificando parcialmente la STC, recaída en el Expediente 2566-2012-PA/TC y en la STC, recaída en el Expediente 3561-2009-PA/TC. (Fundamento 57).

De ello se valen principalmente para establecer que no correspondería la negociación colectiva en materia de remuneraciones a los servidores públicos cuando mencionan en su fundamento 67 y 68 lo siguiente

Si el Perú hubiese ratificado el Convenio 154 de la OIT, la obligación sería distinta, toda vez que la comunidad internacional reconoció en el que la negociación colectiva constituye el medio privilegiado para reglamentar las condiciones de trabajo tanto para el sector público como para el sector privado (artículo 2), reiterando la posibilidad de que los Estados parte adopten la implementación de dicho mecanismo a sus circunstancias particulares (artículos 1.3 y 5.1). Este criterio ha sido desarrollado en el párrafo 50 del mencionado Informe de la CEACR, en cuanto establece que el Estado Miembro que haya ratificado el Convenio 154 "no puede, en consecuencia, seguir limitándose al método de consulta, como sucedía con el Convenio num. 151, y debe promover la negociación colectiva de las condiciones de trabajo y empleo.

Un interesante punto de vista de este primer grupo de magistrados es que no niegan totalmente el derecho de los servidores públicos a intervenir o participar en la determinación de las compensaciones económicas pero no necesariamente a través de la negociación colectiva sino a través de mecanismos alternativos o idóneos para que estos reclamen sus legítimas aspiraciones salariales en forma independiente a lo establecido en la Ley 30057, Ley del Servicio Civil. Así lo señalan en su fundamento.

Es así como, a entender del Tribunal Constitucional, los deberes estatales de garantía y promoción del derecho a la negociación colectiva en la administración pública, así como los fines dirigidos a la mejora de las condiciones de vida y trabajo de los servidores, y el logro del bienestar en las relaciones de estos con sus empleadores, mantienen plena vigencia en el ámbito de las compensaciones no económicas a través de la negociación colectiva. De otro lado, para ser coherente con las obligaciones que derivan del artículo 7 del Convenio 151 de la OIT, debe procurarse también alguna medida idónea para que los trabajadores reclamen sus legitimas aspiraciones salariales - 
independientemente de los criterios objetivos establecidos para los artículos 29 al 32 de la Ley 30057- a través de un mecanismo alternativo. (lo resaltado es nuestro)

\subsubsection{STC del TC recaída en EX 00003-2013-PI/TC y otras demandas de inconstitucionalidad contra el artículo 6 de la ley 29812- Ley de Presupuesto}

El Magno Tribunal se ha pronunciado por la Inconstitucionalidad del artículo 6 de las Leyes de Presupuesto, Ley 29812 y 29951 de los años 2012 y 2013, respectivamente. Estas normas y las siguientes de tipo presupuestario que se publicaban año a año prohibían todo tipo de incremento salarial, remunerativo o económico por parte de las entidades que no esté fijado en las normas de presupuesto. De esta manera, si es que una entidad pública fijaba con un sindicato o con representantes de los trabajadores un incremento remunerativo, tal acuerdo era inválido y, por tanto, su cumplimiento no podía ser exigido dado que contravenía la restricción establecida en las normas presupuestarias.

Una forma de escaparse de esta nefasta prohibición fue derivar la solución de los conflictos por Negociación Colectiva Arbitraje, entre ellos el potestativo. Los árbitros y los tribunales arbitrales inaplicaban las restricciones presupuestarias por considerarlas inconstitucionales y así emitían laudos que contenían incrementos económicos y remunerativos. Posteriormente se comenzó a adicionar disposiciones en las leyes de presupuesto, de carácter sancionador a los árbitros que se pronunciaban sobre las cuestiones prohibidas. Impidiendo de esta manera la solución de negociaciones colectivas en el sector público.

El máximo intérprete de la Constitución estableció que una norma de carácter presupuestario (como lo son las Leyes de Presupuesto) tiene una competencia que se limita a la asignación de recursos a las entidades públicas y a las condiciones para su ejercicio. En ese sentido, el hecho de que estas normas presupuestarias contengan disposiciones que establezcan la forma de escoger a los presidentes de los Tribunales Arbitrales o regulen la actuación de los árbitros violaba iba contra la competencia asignada para tales Leyes, razón por la cual tales disposiciones fueron declaradas inconstitucionales (Fundamentos Jurídicos -en adelante, "FJ"- 39 y 40).En cuanto a la restricción para negociar materia económica en el sector público, el Tribunal 
Constitucional ha señalado que una prohibición absoluta como la contenida en las normas presupuestarias cuestionadas es inconstitucional (FJ 91).

Para ello, el Tribunal planteó una definición de negociación colectiva que implica la posibilidad de negociar, entre otras cosas, las condiciones de trabajo, incluyendo en tal categoría las remuneraciones y los salarios de los trabajadores (FJ 62).

En esa línea, al considerar que parte del contenido constitucionalmente protegido del derecho a la negociación colectivo es la posibilidad de negociar remuneraciones, una prohibición absoluta como la fijada en las Leyes de Presupuesto del año 2012 y 2013 vaciaban de contenido al derecho mencionado.

Una novedad que trae esta sentencia es lo que se llama la Vacatio Sententiae, por el cual han quedado suspendidos los efectos de esta sentencia en la parte relativa a la inconstitucionalidad de las restricciones a la negociación colectiva hasta el inicio de la legislatura 2016-2017, otorgando un plazo de 01 año para la promulgación de tal norma (FJ.71).

\subsubsection{STC recaída en el Expediente 0025-2013-PI/TC, 003-2014-PI/TC, 008- 2014-PI/TC y 017-2014-PI/TC,}

El 26 de abril de 2016 el Tribunal Constitucional emitió la sentencia correspondiente al Expediente 0004-2014PI/TC, 0008-2014PI/TC y 0017-2014PI/TC, respecto a Demandas de Inconstitucionalidad contra diversos artículos de la Ley 30057 - Ley del Servicio Civil. que en su parte final resuelve declarar inconstitucional las siguientes normas:

INCONSTITUCIONAL el artículo 31.2 de la Ley 30057, en el extremo que dispone `...) ni es materia de negociación (...)": por lo que dicha disposición queda subsistente con el siguiente contenido: "La compensación económica se paga mensualmente e incluye la Valorización Principal y la Ajustada, y la Priorizada, de corresponder. El pago mensual corresponde a un catorceavo (1/14) de la compensación económica. Las vacaciones y los aguinaldos son equivalentes al pago mensual. Esta disposición no admite excepciones ni interpretaciones". e)

INCONSTITUCIONAL el artículo 42 de la Ley 30057, en el extremo que dispone "(...) compensaciones no económicas, incluyendo el cambio de (...)", por lo que 
dicha disposición queda subsistente con el siguiente contenido: "Los servidores civiles tienen derecho a solicitar la mejora de sus condiciones de trabajo o condiciones de empleo, de acuerdo con las posibilidades presupuestarias y de infraestructura de la entidad y la naturaleza de las funciones que en ella se cumplen". d)

INCONSTITUCIONAL el artículo 441., de la Ley 30057, en el extremo que dispone "La contrapropuesta o propuestas de la entidad relativas a compensaciones económicas son nulas de pleno derecho". e) INCONSTITUCIONAL el tercer párrafo del artículo 40 de la Ley 30057, en cuanto dispone "Ninguna negociación colectiva puede alterar la valorización de los puestos que resulten de la aplicación de la presente Ley", por lo que dicha disposición queda subsistente con el siguiente contenido: "Los derechos colectivos de los servidores civiles son los previstos en el Convenio 151 de la Organización Internacional del Trabajo (ovo) y en los artículos de la función pública establecidos en la Constitución Política del Perú. No están comprendidos los funcionarios públicos, directivos públicos ni los servidores de confianza Se aplica supletoriamente lo establecido en el Texto Único Ordenado de la Ley de Relaciones Colectivas de Trabajo, aprobado mediante Decreto Supremo 010-2003-TR, en lo que no se oponga a lo establecido en la presente Ley". /// e) Ley 28359, Ley de Situación Militar de los Oficiales de las Fuerzas Armadas. Decreto Legislativo 1149, Ley de la Can-era y Situación del personal de la Policía Nacional del Perú. 90 TRIBUNAL CONSTITUC Caso Ley de Servicio Civil.

INCON STITUCIONAL el artículo 66, del Reglamento General de la Ley 30057, en mo que dispone "(...) y se encuentra además limitada por lo dispuesto en el párrafo del artículo 40 y en el literal b) del artículo 44 (...)", por lo que dicha acción queda subsistente con el siguiente contenido: La negociación colectiva por entidad pública se circunscribe a lo establecido en el artículo 42 de la Ley y en el literal e) de su artículo 43 de la misma Ley".

INCONSTITUCIONAL el primer párrafo del artículo 72, del Reglamento General de la Ley 30057, en el extremo que dispone "(...) si alguna de las peticiones contenidas en el mismo implica una contravención a lo establecido en el párrafo final del artículo 40 de la Ley o acerca de (...)", por lo que dicha disposición queda subsistente con el siguiente contenido: "El procedimiento de la negociación colectiva es el siguiente: Recibido el pliego de reclamos y antes de iniciar la negociación, el Jefe de la Oficina de Recursos Humanos de la entidad Tipo A remitirá copia del mismo a 
SERVIR. Remitirá, también, una copia al Ministerio de Economía y Finanzas que, a través de la Dirección General de Gestión de Recursos Públicos, podrá opinar respecto de algún otro aspecto sobre el cual estimara pertinente pronunciarse".

INCONSTITUCIONAL el artículo 78, del Reglamento General de la Ley 30057, en cuanto dispone "tercer párrafo del artículo 40", por lo que dicha disposición queda subsistente con el siguiente contenido: "Son nulos todos los convenios colectivos y laudos arbitrales que trasgredan lo establecido en el artículo 44 de la Ley así como que excedan los alcances del artículo 42 y el literal e) del artículo 43 de la Ley. La declaratoria de nulidad se sujetará a la normativa correspondiente".

i) INCONSTITUCIONAL el segundo párrafo del artículo 68, del Reglamento General de la Ley 30057, en el extremo que dispone "(...) compensaciones no económicas, incluyendo el cambio de (...)", por lo que dicha disposición queda subsistente con el V siguiente contenido: "El convenio colectivo es el acuerdo que celebran, por una parte, tina o más organizaciones sindicales de servidores civiles y, por otra, entidades públicas Tipo A que constituyen Pliego Presupuestal. De conformidad con lo establecido en el artículo 42 de la Ley, el objeto de dicho acuerdo es regular la mejora de las condiciones de trabajo o de empleo, de acuerdo con las posibilidades presupuestarias y de infraestructura de la entidad y la naturaleza de las funciones que en ella se cumplen".

D INCONSTITUCIONAL el artículo 85.h de la Ley 30057, en el extremo que dispone "la prevaricación", por lo que dicha disposición queda subsistente con el siguiente contenido: "Son faltas de carácter disciplinario que, según su gravedad, pueden ser sancionadas con suspensión temporal o con destitución, previo proceso administrativo: h) El abuso de autoridad o el uso de la función con fines de lucro".

Para una mejor compresión de la sentencia antes mencionada en materia de negociación colectiva. Se presenta a continuación la Tabla $\mathrm{N}^{\circ} 8$ en la que se compara la norma antes y después de las declaratorias de inconstitucionalidad por parte del Tribunal.

Tabla 5.1.

Comparativo entre la norma legal sobre negociación colectiva en el servicio civil anterior y la posterior a la sentencia del Tribunal Constitucional 
2013-PI/TC

INCONSTITUCIONAL el artículo 31.2 de la Ley 30057, en el extremo que dispone (...) ni es materia de negociación (...)"::
"La compensación económica se paga mensualmente e incluye la Valorización Principal y la Ajustada, y la Priorizada, de corresponder. El pago mensual corresponde a un catorceavo (1/14) de la compensación económica. Las vacaciones y los aguinaldos son equivalentes al pago mensual. Esta disposición no admite excepciones ni interpretaciones".

\section{C. INCONSTITUCIONAL el artículo 42 de la Ley 30057, en el extremo que dispone "(...) compensaciones no económicas, incluyendo el cambio de (...)"}

INCONSTITUCIONAL el artículo 441., de la Ley 30057, en el extremo que dispone

e)
INCONSTITUCIONAL
el tercer párrafo del
artículo 40 de la Ley
30057, en cuanto
dispone "Ninguna
negociación colectiva
puede alterar la
valorización de los
puestos que resulten de
la aplicación de la
presente Ley"

\section{Artículo 40. Derechos colectivos del servidor civil}

"Los derechos colectivos de los servidores civiles son los previstos en el Convenio 151 de la Organización Internacional del Trabajo (ovo) y en los artículos de la función pública establecidos en la Constitución Política del Perú. No están comprendidos los funcionarios públicos, directivos públicos ni los servidores de confianza .

Se aplica supletoriamente lo establecido en el Texto Único Ordenado de la Ley de Relaciones Colectivas de Trabajo, aprobado mediante Decreto Supremo 010-2003-TR, en lo que no se oponga a lo establecido en la presente Ley.

Ninguna negociación colectiva
Artículo 42. De las solicitudes de cambio de condiciones de trabajo o condiciones de empleo

"Los servidores civiles tienen derecho a solicitar la mejora de sus condiciones de trabajo o condiciones de empleo, de acuerdo con las posibilidades presupuestarias y de infraestructura de la entidad y la naturaleza de las funciones que en ella se cumplen"

\section{(Expulsado de la Ley)}

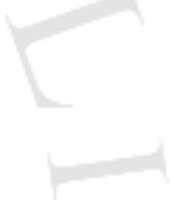

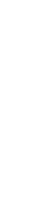

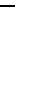


puede alterar la valorización de

los puestos que resulten de la

aplicación de la presente Ley.

Fuente: STC recaída en los Expedientes 00025-2013-PI/TC y otros.

Tabla 5.2.

Comparativo entre la norma reglamentaria sobre negociación colectiva en el servicio

civil anterior y la posterior a la sentencia del Tribunal Constitucional

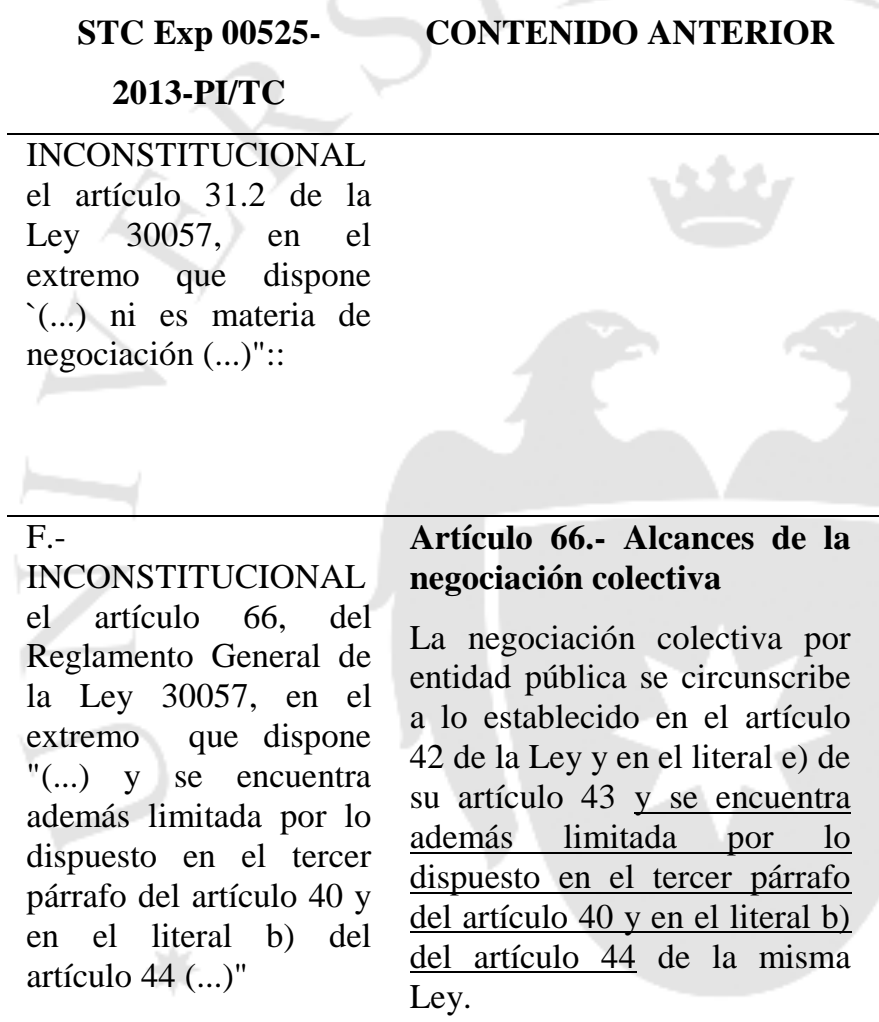

G.-

el primer párrafo del artículo $72, \quad$ del Reglamento General de la Ley 30057, en el extremo que dispone "(...) si alguna de las peticiones contenidas en el mismo implica una contravención a lo establecido en el párrafo final del artículo 40 de la Ley o acerca de (...)",

\section{Artículo 72.- Procedimient de la negociación colectiva}

El procedimiento de la negociación colectiva es el siguiente:

Recibido el pliego de reclamos y antes de iniciar la negociación, el Jefe de la $\mathrm{O}$ cina de Recursos Humanos de la entidad Tipo A remitirá copia del mismo a SERVIR. Remitirá, también, una copia al Ministerio de Economía y Finanzas que, a través de la Dirección General de Gestión de Recursos Públicos, podrá opinar respecto de si alguna de

\section{CONTENIDO POSTERIOR}

"La compensación económica se paga mensualmente e incluye la Valorización Principal y la Ajustada, y la Priorizada, de corresponder. El pago mensual corresponde a un catorceavo (1/14) de la compensación económica. Las vacaciones y los aguinaldos son equivalentes al pago mensual. Esta disposición no admite excepciones ni interpretaciones".

\section{Artículo 66.- Alcances de la negociación colectiva}

La negociación colectiva por entidad pública se circunscribe a lo establecido en el artículo 42 y en el literal e) de su artículo 43 de la misma Ley".

\section{Artículo 72.- Procedimiento de la negociación colectiva}

"El procedimiento de la negociación colectiva es el siguiente: Recibido el pliego de reclamos y antes de iniciar la negociación, el Jefe de la Oficina de Recursos Humanos de la entidad Tipo A remitirá copia del mismo a SERVIR. Remitirá, también, una copia al Ministerio de Economía y Finanzas que, a través de la Dirección General de Gestión de Recursos Públicos, podrá opinar respecto de algún otro aspecto sobre el cual estimara pertinente pronunciarse".

(...). 
las peticiones contenidas en el

mismo implica una contravención a lo establecido en

(parte del párrafo expulsado de la Ley).

el párrafo final del artículo 40 de la Ley o acerca de algún otro aspecto sobre el cual estimara pertinente pronunciarse. (...)

H.INCONSTITUCIONAL el artículo 78, del Reglamento General de la Ley 30057, en cuanto dispone "tercer párrafo del artículo 40",

iI.-

INCONSTITUCIONAL

el segundo párrafo del artículo 68, del Reglamento General de la Ley 30057, en el extremo que dispone "(...) compensaciones no económicas, incluyendo el cambio de (...)",
Artículo 78.- Nulidad de convenios y laudos

Son nulos todos los convenios colectivos y laudos arbitrales que trasgredan lo establecido en el artículo 44 de la Ley así como que excedan los alcances del tercer párrafo del artículo 40 , artículo 42 y el literal e) del artículo 43 de la Ley. La declaratoria de nulidad se sujetará a la normativa correspondiente.
"Son nulos todos los convenios colectivos y laudos arbitrales que trasgredan lo establecido en el artículo 44 de la Ley así como que excedan los alcances del artículo 42 y el literal e) del artículo 43 de la Ley. La declaratoria de nulidad se sujetará a la normativa correspondiente".
Artículo 68.- Definición de convenio colectivo
El convenio colectivo es el acuerdo que celebran, por una parte, una o más organizaciones sindicales de servidores civiles $y$, por otra, entidades públicas Tipo A que constituyen Pliego Presupuestal.
De conformidad con lo establecido en el artículo 42 de la Ley, el objeto de dicho acuerdo es regular la mejora de las compensaciones no económicas, incluyendo el cambio de condiciones de

\section{Artículo 68.- Definición de convenio colectivo \\ El convenio colectivo \\ "El convenio colectivo es el acuerdo que celebran, por una parte, una o más organizaciones sindicales de servidores civiles y, por otra, entidades públicas Tipo A que constituyen Pliego Presupuestal. \\ De conformidad con lo establecido en el artículo 42 de la Ley, el objeto de dicho acuerdo es regular la mejora de las condiciones de trabajo o de empleo, de acuerdo con las posibilidades presupuestarias y de infraestructura de la entidad y la naturaleza de las funciones que en ella se cumplen.} trabajo_ o de empleo, de acuerdo con las posibilidades presupuestarias y de infraestructura de la entidad y la naturaleza de las funciones que en ella se cumplen.

Fuente: STC recaída en los Expedientes 00025-2013-PI/TC y otros.

Conforme a las tablas anteriores podemos concluir que la Ley del Servicio Civil y su Reglamento establecieron unas regulaciones que afectaban el derecho a la negociación colectiva y que el Tribunal Constitucional ha tenido que pronunciarse al respecto, 
expulsando dichas normas del Sistema Jurídico Nacional a declarar su inconstitucionalidad.

Ésta sentencia en materia de negociación colectiva en el Empleo Público, viene a ser una ratificación del pronunciamiento de este magno tribunal recaído en el expediente 0003-2013-PI/TC (artículo 6 de Ley de Presupuesto) que establecía la prohibición de las representaciones sindicales del empleo público a realizar negociaciones colectivas sobre cuestiones económicas.

El fundamento principal de este pronunciamiento es que el derecho a la negociación colectiva es de nivel constitucional, especialmente lo establecido en el artículo 28 y 42 de la Constitución; se debe respetar los Tratados Internacionales ratificados por el Perú especialmente los Convenios 151 (Derechos Colectivos de los Servidores Públicos) y 98 (Convenio sobre Negociación Colectiva). De otro lado, este pronunciamiento ha optado por la teoría contractualista respecto a la relación Estado Servidores Públicos al considerar que estos últimos también son trabajadores y que como tal le corresponde deberes y derechos como cualquier trabajador-

La sentencia ha considerado que también se debe respetar el principio de Provisión Presupuestaria del artículo 77 y 78 de la Constitución Política al establecer que los beneficios obtenidos en las citadas negociaciones colectivas deben ser posteriormente revisadas y aprobadas por los órganos correspondientes (Poder Legislativo)

Finalmente la Sentencia del Tribunal Constitucional exhorta nuevamente al Congreso de la República para que en el periodo legislativo 2016-2017 desarrolle legislativamente el procedimiento de la negociación colectiva económica en la administración pública, para lo cual establece determinados lineamientos que se detallan en la Tabla $N^{\circ} 10$ y 11.

Tabla 5.3.

Lineamientos que orientarán la negociación ecolectiva economica en la administración pública constitucional (1)

FUNDAMENTO STC 0013-

DETALLE 2013-TC/AI

1.- Derecho a la información y Un proceso adecuado de negociación colectiva exige que las organizaciones transparencia (Fundamento sindicales o grupo de trabajadores públicos dispongan, con la suficiente 178) antelación, de la información y de los elementos necesarios para negociar en 
condiciones de igualdad.

2.- Intervención de una Es posible la intervención de alguna autoridad pública competente cuando el autoridad económica financiera. procedimiento de negociación colectiva está referido a aspectos remunerativos u (Fundamento 179-180) otras clausulas que puedan tener impacto económico en el programa presupuestario estatal. Tal intervención, por obvio que parezca, no puede suponer una injerencia en la autonomía de las partes. "corresponde al legislador definir cuáles son las instancias gubernamentales competentes.

3.- Clausulas de reajuste salarial Dado que los ingresos de los servidores del Estado dependen del presupuesto (Fundamento 180) público, resulta admisible que se establezcan determinadas reglas de ajuste salarial que contemple un margen en el que las partes puedan negociar las cláusulas de índole pecuniaria. Es labor del legislador establecer un marco legal que garantice el reajuste salarial de los trabajadores, pero también la de garantizar que estos no excedan a lo razonable.

4.- Negociación económica anticipada (Fundamento 182)

Fuente Sentencia del Tribunal Constitucional Exp. 00025/2’13-AI/TC y otros

5.- Situaciones excepcionales
en que los aumentos
remunerativos no puedan ser
fijados por negociación
colectiva (Fundamento 184)
colectiva (Fundamento 184) trabajadores.

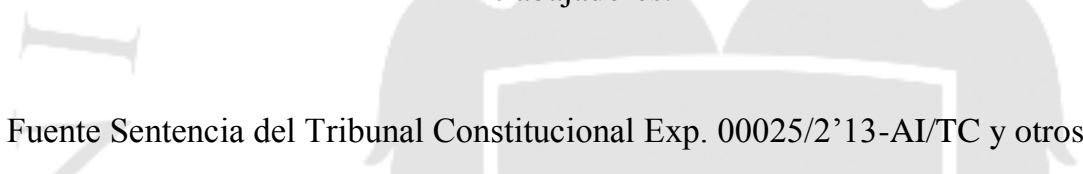

Para que la negociación colectiva sea plenamente compatible con el principio de equilibrio presupuestario, esta debe ser celebrada o decidida con la suficiente anticipación a la formulación o elaboración del proyecto de presupuesto anual de la entidad pública. Aquello a fin de que, ese proyecto sea consolidado por el MEF y ser aprobado por el Congreso de la República.

La OIT tiene establecido que la negociación colectiva no puede resultar ajeno a las posibilidades económicas de los Estados. Por ende, si un gobierno, por razones de interés económico nacional, y en el marco de una política de estabilización, considerara que el monto de las remuneraciones no puedan fijarse por N.C., puede limitarse a lo necesario, no exceder de modo razonable e ir acompañada de las garantías adecuadas para proteger el costo de vida de los

Tabla 5.4.

Lineamientos que orientarán la negociación ecolectiva economica en la administración

pública constitucional (2)

FUNDAMENTO STC 0013-2013TC/AI

6.- Suspensión de negociación colectiva económica por razones económicas financieras del Estado. (Fundamento 185)

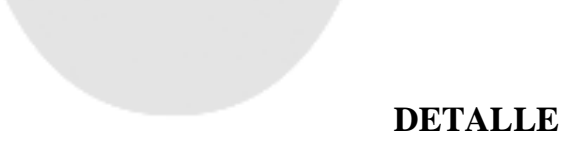

El legislador puede prever que, durante la época de crisis, los trabajadores del sector público no puedan negociar el incremento anual del salario. Estas limitaciones son constitucionales siempre que sean de naturaleza temporal y respondan a una situación real de urgencia, como la de una crisis económica y financiera.

7.- Plazo razonable de limitación al derecho de negociación colectiva (Fundamento 187)

la OIT ha establecido que "un período de tres años de limitación del derecho de negociación colectiva en materia de remuneraciones en el marco de una política de estabilización económica, constituye una restricción considerable, y la legislación que la impone debería dejar de tener efectos como máximo en las fechas estipuladas en la ley, o incluso antes si mejora la situación fiscal y económica.

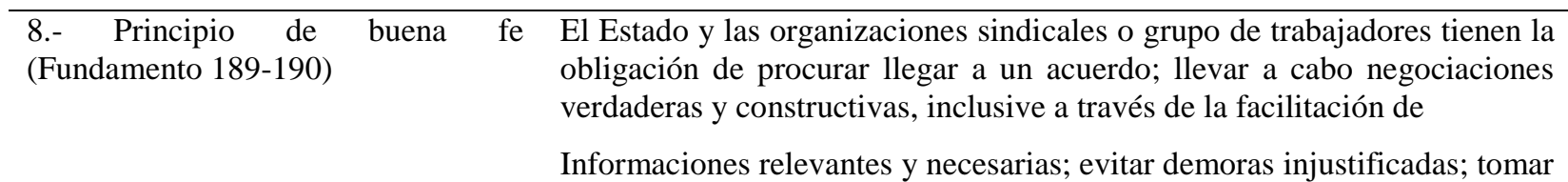


en cuenta de buena fe los resultados de las negociaciones, y respetar mutuamente los compromisos asumidos y los resultados obtenidos a través de la N.C.

9.- Facultad del Estado de realizar ajuste a las remuneraciones (Fundamento 193)
El reajuste de las remuneraciones de los servidores civiles no es pues una cuestión cuya evaluación ha de realizarse de manera exclusiva o a propósito de un proceso de negociación colectiva entre el Estado y los servidores públicos, sino que, bien entendidas las cosas, también corresponde al Estado, como empleador, adecuar — dentro de un margen temporal razonable - los salarios de los servidores públicos al contexto económico-social del país. Ello a fin de asegurar no sólo una remuneración equitativa y suficiente, sino también para contribuir a la mayor eficacia y efectividad de los servicios que éstos prestan.

Fuente Sentencia del Tribunal Constitucional Exp. 00025/2'13-AI/TC y otros

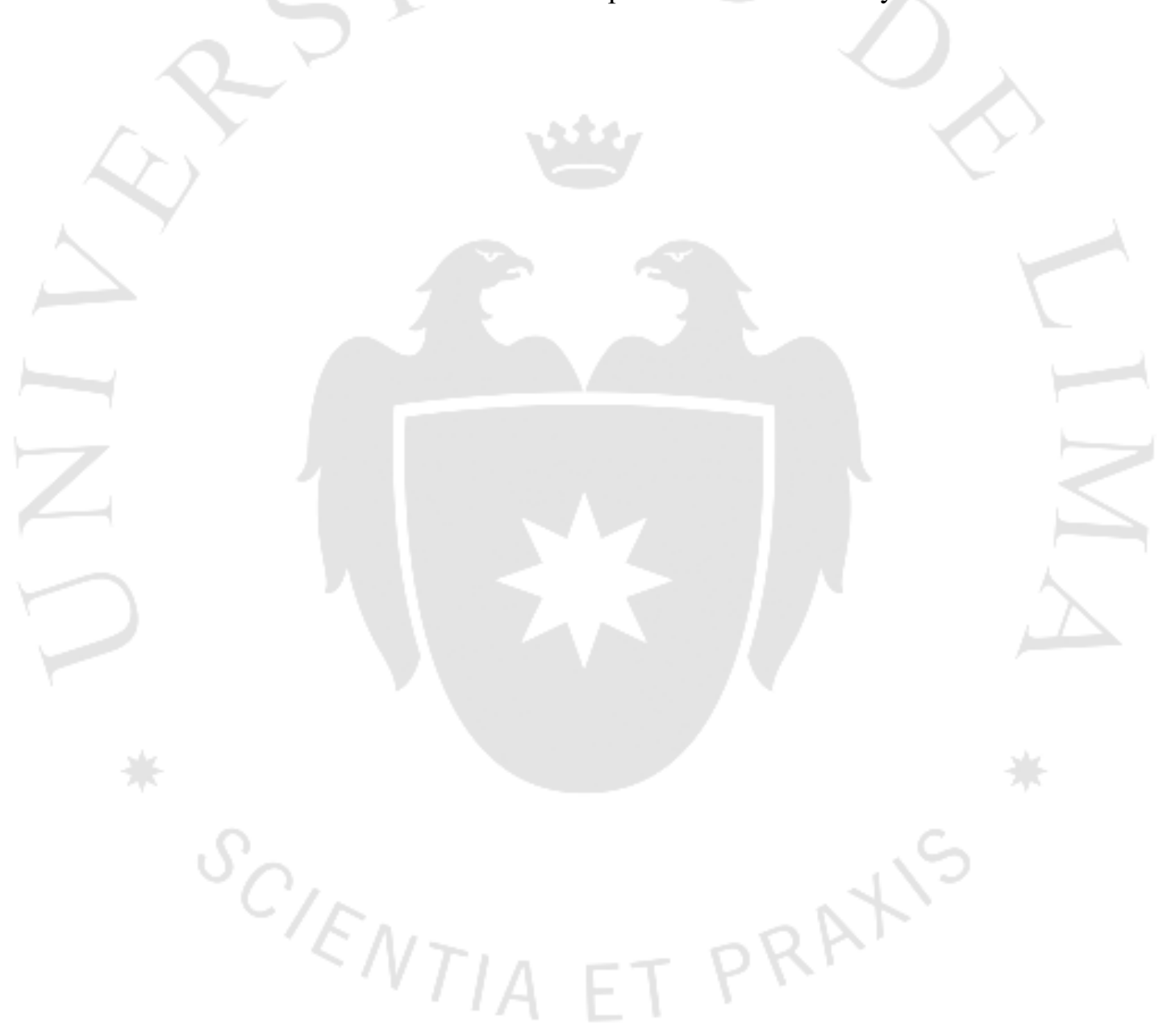




\section{CAPITULO 6: LA NEGOCIACIÓN COLECTIVA EN EL ÁMBITO INTERNACIONAL}

La Organización Internacional del Trabajo - OIT, creada en 1919 y recreada en 1944 con la Declaración de Filadelfia tiene como una de sus misiones "la obligación solemne de fomentar, entre todas las naciones del mundo, fomentar programas que permitan lograr, entre otros, el derecho a la negociación colectiva. Inicialmente esta misión se enfocó en las relaciones laborales de orden privado, por lo que se aprobaron los convenios: Convenio sobre la Libertad Sindical y la Protección del Derecho de Sindicación", "Convenio sobre el Derecho de Sindicación y de Negociación Colectiva. Posteriormente la OIT se preocupó de que éstos derechos también sean reconocidos por los estados a los trabajadores del sector público, es por ello que se aprobaron los convenios "Convenio Sobre La Protección del Derecho De Sindicación y los Procedimientos para Determinar Las Condiciones de Empleo En la Administración Pública" y "Convenio sobre la Negociación Colectiva", cuyos detalles los comentaremos en los siguientes ítems.

\subsection{La Negociación Colectiva y la Organización Internacional del Trabajo - OIT}

Ante las dudas y el poco incentivo por parte de los estados de aprobar los convenios 151 y 154 y a las numerosas quejas de las organizaciones sindicales de los servidores públicos, traducido en las posiciones unilateralista o estatutaria de muchos gobiernos que se negaban a reconocer este derecho, principalmente por razones de orden presupuestario, y por otro lado el reforzamiento de las condiciones de orden contractualista o de derecho laboral que exigían que los derechos a la negociación colectiva también se les debería aplicar los servidores públicos de forma irrestricta, se hizo necesario que la propia institución internacional realice un meditado estudio sobre esta problemática.

De lo antes mencionado la Oficina Internacional de Trabajo, en la Centésima segunda reunión de la Conferencia Internacional del Trabajo del mes de junio del año 
2013 aprobó el Estudio especializado en la materia denominado "La Negociación Colectiva en la Administración Pública. Un camino a seguir”. Este importante documento tiene dos partes

La primera de ellas, se refiere a los derechos sindicales y facilidades en la administración pública y se refiere principalmente al análisis del convenio 151; a los derechos civiles y políticos de los empleados públicos, a la protección a los actos de discriminación antisindical, a las facilidades concedidas a los empleados públicos, entre otros. También se analizan los aspectos conceptuales y procedimentales respecto a la consulta.

La segunda parte, que es la que corresponde a nuestro estudio, se refiere a la negociación colectiva en la administración pública, tocándose entre los principales temas a las ventajas de la negociación colectiva; las mutaciones en la administración pública; las normas de la OIT relacionado a la negociación colectiva y su evolución; a las modalidades de negociación colectiva; a los campos de aplicación de los convenios 151 y 154 de la OIT; las partes de la negociación y naturaleza de los convenios colectivos; la buena fe, la representatividad y el reconocimiento de las organizaciones sindicales; la autonomía de las partes y el principio de no injerencia y finalmente el procedimiento de negociación.

Con relación a algunas conclusiones que se pueden llegar del documento antes citado, coincidimos con importantes estudios sobre la materia (A. Orsatti y C. Rubiano 2014).

Los acuerdos alcanzados pueden no tener la fuerza y naturaleza de un convenio colectivo, ni fuerza de ley entre las partes o carácter contractual, por basarse en regímenes y procedimientos nacionales que, si bien reconocen la negociación colectiva dentro de este sector, no están dispuestos a renunciar a las particularidades y exigencias de su régimen estatutario.

En aquellos países en que las condiciones de empleo de los funcionarios públicos estén regidas por leyes o disposiciones especiales, las negociaciones relativas a la modificación de tales leyes o disposiciones especiales no precisan convertirse en acuerdos jurídicamente obligatorios, siempre y cuando se los resultados sean tenidos en cuenta de buena fe. Por ello, se admite que los convenios colectivos pueden tener un 
valor puramente «pragmático» o constituir una especie de entendimiento tácito, si se aplican en la práctica.

\subsection{Los Convenios OIT relacionados a la Negociación Colectiva}

Los Estados, sus organizaciones sindicales y la Organización Internacional del Trabajo han suscrito importantes convenios relativos a la Sindicalización y a la Negociación Colectiva. Entre los principales convenios podemos mencionar a lo siguientes:

Convenio $\mathrm{N}^{\circ} 87$ de la Organización Internacional del Trabajo: Convenio relativo a la libertad sindical y a la protección del derecho de sindicación

Este convenio constituye la norma de mayor importancia que protege la libertad sindical y el derecho de sindicación. Adoptado en la Conferencia General de la OIT, en la ciudad de San Francisco, el 17 junio de 1948. Entre sus principales aportes podemos mencionar el siguiente:

Libertad Sindical: Desarrollado en el artículo 2: "Los trabajadores y los empleadores, sin ninguna distinción y sin autorización previa, tienen el derecho de constituir las organizaciones que estimen conveniente, así como de afiliarse a estas organizaciones. Con la sola condición de observar los estatutos de la misma»"

Entendemos, por lo tanto, que garantiza a los trabajadores y a los empleadores el ejercicio de la libertad sindical, sin distinción de raza, sexo, credo, opiniones políticas, nacionalidad; por supuesto, debiendo tener en cuenta las restricciones determinadas por el Artículo 9 del presente convenio. ${ }^{22}$

El Convenio $\mathrm{N}^{\circ} 98$ de la OIT: Convenio relativo a la aplicación de los principios del derecho de sindicación y de negociación colectiva.

Este convenio se refiere al derecho de sindicación y negociación colectiva. Fue adoptado en la Conferencia General de la OIT de fecha 01 julio 1949 y fue aprobado por el parlamento nacional mediante Resolución $\mathrm{N}^{\circ} 14712$ el 18 de noviembre 1963. Su principal característica es, a diferencia del Convenio 87, la exclusión de su ámbito de aplicación a otras categorías de funcionarios diferentes de las fuerzas armadas y la policía. En efecto el Convenio 98, en su artículo 6, no trata la situación de los

\footnotetext{
${ }^{22}$ El Texto del Convenio 98 se puede ubicar en el Anexo 1 de la presente investigación.
} 
funcionarios públicos, éste artículo señala además, que no debe interpretarse de modo alguno el menoscabo de sus derechos. ${ }^{23}$

El Convenio $\mathrm{N}^{\circ} 151$ de la OIT: Sobre las relaciones de trabajo en la administración pública, 1978

Este Convenio, ratificado por el Estado Peruano en la Constitución de 1979, otorga adecuada protección al servidor público contra todo acto de discriminación antisindical en relación con su empleo. Prohíbe todo acto que sujete el empleo del servidor público a la condición que no se afilie o que deje de ser miembro de una organización sindical. Asimismo prohíbe los despidos o el perjuicio a los servidores públicos a causa de su afiliación a las organizaciones laborales.

Este instrumento comprende las siguientes partes:

Parte I: $\quad$ Campo de aplicación y definiciones (referida anteriormente)

Parte II: $\quad$ Protección del derecho de sindicación

Parte III: $\quad$ Facilidades que deben concederse a las organizaciones de empleados públicos.

Parte IV: Procedimiento para la determinación de las condiciones de empleo.

Parte V: $\quad$ Solución de conflictos.

Parte VI: Derechos civiles y políticos

Parte VII: Disposiciones finales ${ }^{24}$

El Convenio 154 de la OIT “Convenio sobre fomento de la Negociación Colectiva 1981.

El convenio sobre la negociación colectiva, 1981 (Convenio 154), tiene la virtud de extender el derecho de negociación colectiva a todos los trabajadores de la administración pública, situación que observamos como opcional en el convenio 151. Estas modalidades de negociación colectiva pueden fijarse en la legislación o en las prácticas nacionales en particular mediante convenios colectivos, laudos arbitrales $\mathrm{u}$ otros medios.

\footnotetext{
${ }^{23}$ El Texto del Convenio 98 se puede ubicar en el Anexo 2 de la presente investigación.

${ }^{24}$ El Texto del Convenio 98 se puede ubicar en el Anexo 3 de la presente investigación.
} 
El presente convenio no ha sido ratificado por el Perú y varios países en América Latina, por lo que no se encuentran obligados a otorgar este derecho a sus servidores públicos.

Con relación a este convenio, el texto de la obra "La negociación colectiva en la administración pública OIT (OIT 2013) se establece algunos aspectos que diferencia a la negociación colectiva en empleo público y en el empleo privado en los siguientes términos:

“242. El párrafo 3 del artículo 1 del Convenio núm. 154 acepta modalidades particulares de aplicación en lo concerniente al derecho de negociación colectiva en la administración pública. Estas modalidades podrán fijarse en la legislación o la práctica nacionales, en particular mediante convenios colectivos, laudos arbitrales $\mathrm{u}$ otros medios (artículo 4 del Convenio núm. 154).

243. Antes de analizar estas modalidades particulares en los próximos capítulos, la Comisión estima necesario examinar ciertas diferencias entre el empleo público y el empleo privado y las particularidades de la administración pública - que han sido señaladas por numerosos autores - que justifican dichas modalidades de aplicación: Las estructuras de la administración pública son muy complejas, especialmente en los países industrializados. Sus competencias, capacidades y procedimientos se rigen por un gran número de leyes y reglamentos que abarcan la mayoría de las cuestiones que afectan a los ciudadanos y las empresas. (...)

En el marco del Estado, la administración pública es normalmente el principal empleador. - Mientras que en el sector privado las empresas persiguen intereses particulares y se caracterizan en general por la búsqueda de beneficios económicos, el Estado y la administración pública tienen la obligación de velar por el interés general. A este respecto, cuando las instituciones creadas o controladas por el Estado se rigen por el derecho privado (por ejemplo, las empresas estatales o mixtas o los monopolios fiscales del Estado), el objetivo de contribuir al interés general y responder a necesidades de los ciudadanos incide en gran medida en las políticas, la gestión y La negociación colectiva en la administración pública: (...).

En muchos países, y con frecuencia por mandato constitucional, se procede a la regulación de las condiciones generales de empleo de los funcionarios públicos de manera más o menos exhaustiva, según el caso, por medio de leyes especiales, en el 
marco del derecho administrativo y no en el marco de la legislación laboral (en particular del Código del Trabajo). Por otra parte, en algunos países, se aplican estatutos normativos específicos a ciertos funcionarios públicos (por ejemplo, fuerzas armadas, policía, personal docente, personal de la seguridad social, etc. (...).

En este sentido, la negociación colectiva en la administración pública está condicionada por diferentes motivos por los procesos presupuestarios y su lógica. Los resultados presupuestarios de los Estados a su vez dependen de numerosos factores económicos: el nivel de crecimiento económico, el nivel de ingresos y la inflación, las tasas de interés y la deuda pública. También dependen del marco político e institucional (nivel de descentralización, grado de estabilidad política y peso del poder ejecutivo comparado con el poder legislativo), la tendencia política del Gobierno, la demografía, la tasa de desempleo, la participación del sector público en el PIB, las preferencias de los contribuyentes, la evolución de los ciclos económicos y las reglas presupuestarias aplicables (grado de disciplina presupuestaria, margen de las previsiones basadas en las variables económicas, normas más o menos estrictas en materia de endeudamiento público). - Debido al impacto de las remuneraciones de los empleados públicos en el nivel de la deuda pública (por ejemplo, en 2011, en los países de la Unión Europea, las remuneraciones del sector público equivalían al 22,1 por ciento del gasto público total), durante el proceso de negociación de las remuneraciones de los funcionarios públicos, las autoridades exponen los lineamientos de la política económica del Gobierno y los retos macroeconómicos, en vista de que los ingresos del Estado no dependen principalmente de los beneficios económicos y de las ganancias - como en el caso de las empresas - sino de los impuestos, y de que las autoridades deben rendir cuentas de su gestión ante los ciudadanos.”

Podemos concluir que los convenios estudiados han sido ratificados por diferentes países de la región, tal como se grafica en la tabla siguiente

Tabla 6.1.

Convenios OIT ratificados por los países de la región

\begin{tabular}{lcccc}
\multirow{2}{*}{ País } & \multicolumn{5}{c}{ Convenios de la OIT ratificados } \\
\cline { 2 - 5 } & 87 & 98 & 151 & 154 \\
\hline Argentina & $\mathrm{X}$ & $\mathrm{X}$ & $\mathrm{X}$ & $\mathrm{X}$ \\
\hline Brasil & & $\mathrm{X}$ & $\mathrm{X}$
\end{tabular}




\begin{tabular}{lllll} 
Chile & $\mathrm{X}$ & $\mathrm{X}$ & $\mathrm{X}$ & $\mathrm{X}$ \\
\hline Colombia & $\mathrm{X}$ & $\mathrm{X}$ & $\mathrm{X}$ & \\
\hline Ecuador & $\mathrm{X}$ & $\mathrm{X}$ & $\mathrm{X}$ & \\
\hline Perú & $\mathrm{X}$ & $\mathrm{X}$ & & \\
\hline Costa Rica & $\mathrm{X}$ & $\mathrm{X}$ & &
\end{tabular}

Fuente: Situación actual comparada de las Relaciones Laborales en el Sector Público de nueve países de América Latina. Oficina Internacional del Trabajo - 2005.

\subsection{Regímenes de la negociación colectiva en diversos países de la región}

La situación del empleo público en general y de la negociación colectiva en este sector en particular viene pasando de un estado proteccionista e interventor, bajo el paradigma burocrático, hacia un estado moderno flexible y eficiente bajo el nuevo paradigma de la gestión pública, en la que se comienza aplicar instrumentos y técnicas extraídas del régimen laboral privado, como la racionalidad económica, la eficacia y eficiencia, la flexibilidad laboral con disminución de la estabilidad laboral permanente, etc.

Un importante estudio sobre el empleo público comparado corresponde a María de Sandé Pérez Bedmar, con su obra "Empleo y prestación de servicios en la Administración Pública (Valladolid 2006) donde describe con mucha calidad las principales características del empleo público en diferentes partes del mundo en especial de la región sudamericana al año 2005.

Teniendo como estudios anteriores, entre ellos los de Sandé (2006), Alvaro Orsatty y Camilo Rubiano, con el apoyo de trabajadores municipales de las Américas, publicaron la obra "Organización y Negociación Colectiva de los Trabajadores del Sector Público en América Latinas (Orsatty y Rubiano marzo 2014). Tomando como base este documento podemos concluir, como ellos,m en lo siguiente:

En general, se identifica en la región la existencia de un modelo de regulación estatal de la negociación colectiva de carácter claramente intervencionista y restrictivo en el ámbito del sector público. Un caso extremo es, en algunos países, la prohibición legal del derecho a la organización sindical, que obviamente determina la imposibilidad de la negociación colectiva. 
Además, en varios otros países no se autoriza la negociación de los sindicatos. En este contexto, es decir: más allá de lo previsto en la regulación estatal, una evaluación sindical de la práctica negocial a nivel nacional encuentra una considerable extensión de éste, incluyendo los países en que no se autoriza la negociación colectiva como tal e, incluso aquellos en que no se permite la sindicalización de estos trabajadores.

Por lo tanto, la imagen que queda de este análisis es que la dinámica en el sector público tiende a ser la inversa a la del sector privado, es decir, en vez de una brecha negativa respecto de la norma, se encuentra una positiva, como resultado de que la práctica va más lejos que la norma. El enfoque de OIT, implica el reconocimiento y la asimilación de este panorama regional (y el de otras regiones, seguramente), al destacar la importancia de las consultas y acuerdos no convencionales, si bien recomendando una negociación colectiva como tal, similar al sector privado en todo lo que sea posible.

Lo antes mencionado se traduce en la tabla preparada sobre la base de este informe, agrupando a determinados países de Latinoamérica en las siguientes materias:

- Países con sistemas nacionales de Negociación Colectiva

- Países con sistemas parciales de Negociación Colectiva\}

- Países con práctica de negociación no convencional

- Países con restricciones a la sindicalización y a la negociación colectiva

Dicho criterios se podrán observar en la tabla siguiente:

Tabla 6.2.

Regímenes de negociación colectiva en países de América Latina

\begin{tabular}{|c|c|c|c|}
\hline \multirow{3}{*}{\multicolumn{2}{|c|}{$\begin{array}{lcr}\text { Países } & \text { con } & \text { sistemas } \\
\text { nacionales } & \text { de } & \text { Negociación } \\
\text { Colectiva } & & \end{array}$}} & Uruguay & $\begin{array}{l}\text { A partir de la nueva legislación (2009). La cobertura } \\
\text { alcanzada es prácticamente total, excepto en algunos } \\
\text { municipios }\end{array}$ \\
\hline & & Venezuela & $\begin{array}{l}\text { La nueva legislación (2012) formaliza la negociación } \\
\text { nacional, que ya existía. La evaluación sindical encuentra } \\
\text { crecientes restricciones en la práctica. }\end{array}$ \\
\hline & & Paraguay & $\begin{array}{l}\text { La normativa permite la negociación en la administración } \\
\text { pública para trabajadores en unidades con } 20 \text { y más. La } \\
\text { cobertura es de alrededor del } 20 \% \text {. }\end{array}$ \\
\hline
\end{tabular}


Organización sindical con Argentina Sistemas parciales de negociación colectiva
La normativa permite negociación colectiva mediante regímenes específicos, los que han sido adoptados en la administración pública nacional y sector docente, así como en una parte de las administraciones públicas provinciales y municipales.

La cobertura alcanzada es superior al $60 \%$

Colombia Existe normativa reciente (2012) en favor de la
negociación colectiva a partir de la ratificación de los C151 y C154, aunque la opinión sindical es que se desvirtúa el contenido. Por el momento, solo se ha alcanzado un bajo nivel de negociación en la administración pública, seguridad social y hospitales públicos municipales

Costa Rica Normativa que permite la negociación en algunas categorías. Resistencia del Estado a cumplirla, aunque avalada por la Corte Suprema. La cobertura alcanzada era cercana al 40\%, pero en 2013 se agregó el convenio con el magisterio, con lo que casi la duplica.

Guatemala La normativa permite la negociación colectiva a nivel de entidad pública. Se han alcanzado negociaciones importantes

en salud y magisterio

Nicaragua La normativa autoriza la negociación a nivel de entidad pública, pero excluye a una extensa lista de categorías. Se ha alcanzado una importante negociación en salud, magisterio y universidades

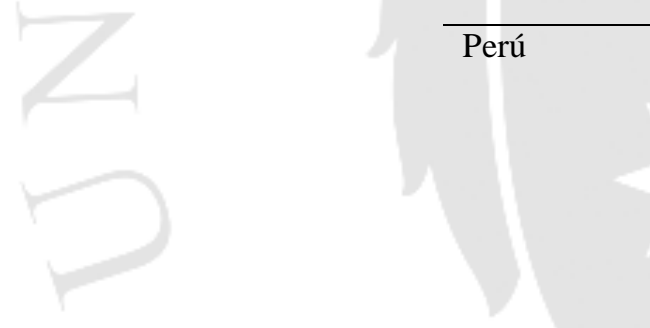

La normativa permite la negociación colectiva para ciertas categorías y subsectores. La cobertura alcanzada estimada es del al $25 \%$.

En el año 2013 se promulgó la Ley del Servicio Civil, que prohibía la negociación colectiva en materia económica; sin embargo, el Tribunal Constitucional declaró inconstitucional dicha prohibición en el 2016. ${ }^{25}$

Países con práctica de Brasil La normativa no autoriza negociación colectiva, pero negociación no convencional existe una extendida práctica de acuerdos en las grandes ciudades. Luego de la ratificación del C151 (2010), se ha creado un grupo de trabajo para comenzar a discutir la forma de incorporar sus contenidos a la normativa. La cobertura alcanzada estimada es de $50 \%$.

México La normativa no autoriza la negociación colectiva, pero existen procedimientos de consulta con los sindicatos sobre condiciones de trabajo.

Bolivia La normativa no autoriza la negociación colectiva, pero ello ha sido revisado por la reforma constitucional de 2008 la negociación colectiva. Existen prácticas de negociación con los sectores de salud y educación.

Países con restricciones a la Panamá sindicalización y a la
No se permite la organización sindical ni la negociación colectiva en el sector público. Existe un procedimiento de solución de conflictos colectivos que puede tener como resultado un acuerdo colectivo. También existe un

${ }^{25}$ Con la Ley 30057, Ley del Servicio Civil (2013) y sus modificaciones impuestas por el Tribunal Constitucional (2016) la cobertura, en nuestra opinión, alcanzará a un $90 \%$. 
Chile No se permite la organización sindical ni la negociación colectiva. Se mantiene una práctica permanente de consulta con la principal central sindical, que da lugar a acuerdos. Un estimado sobre la cobertura alcanzada es del $50 \%$.

República No se permite la organización sindical ni la negociación Dominicana colectiva. Existen acuerdos en las áreas de salud y educación.

\begin{tabular}{ll}
\hline Honduras & Se excluye de la organización sindical a un extenso \\
& número de trabajadores del sector público, y no se \\
& autoriza la negociación colectiva. Existen procedimientos \\
& basados en "respetuosos memoriales", pero no dan lugar a \\
& una negociación. En la práctica, existen acuerdos en las \\
& áreas de salud y educación
\end{tabular}

El Salvador Se excluye de la organización sindical a una extensa lista de categorías, y se admite negociación a nivel de entidades. Se han alcanzado negociaciones colectiva en algunos sectores.

Ecuador No se permite la organización sindical a los trabajadores del sector público que no sean "obreros", a quienes se les permite la negociación colectiva.

Fuente: Cuadro modificado por la Ley 30057 y Sentencias del Tribunal Constitucional Peruano sobre el cuadro original preparada por A.Orsatti y C.Rubiano (2014)

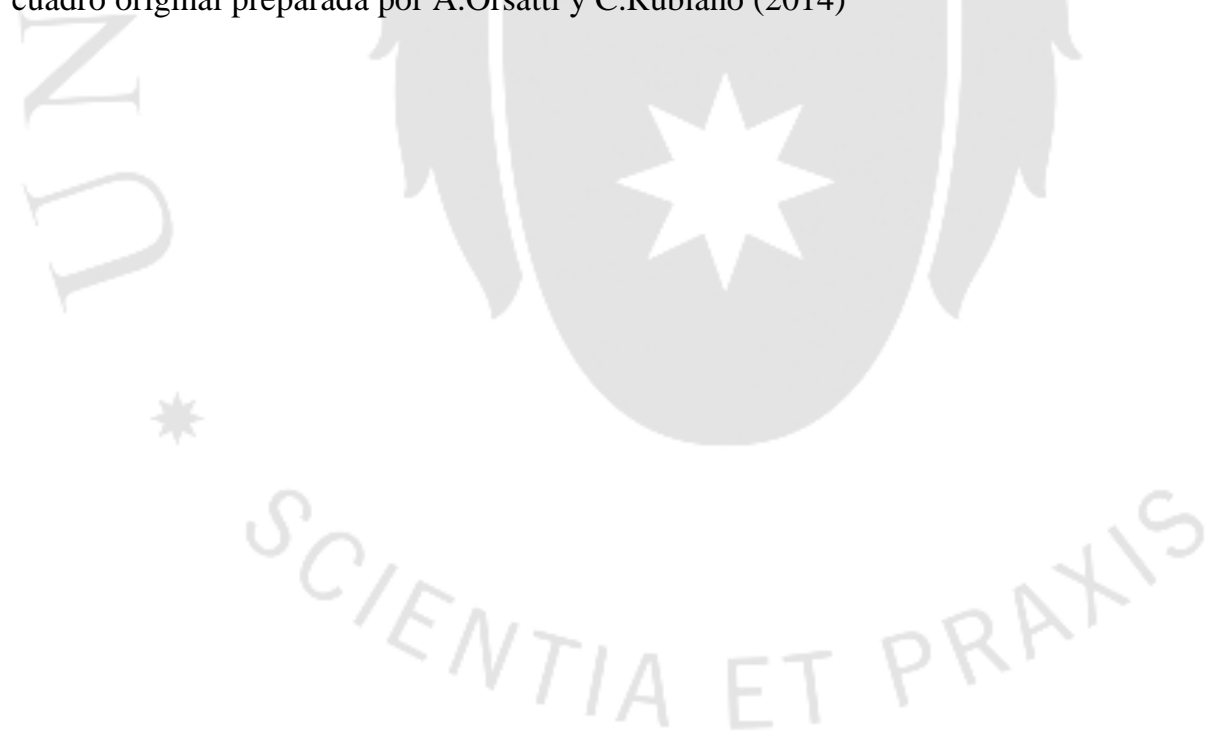




\section{CONCLUSIONES}

- Los fundamentos jurídicos que permiten confirmar la afectación del derecho de negociación colectiva son los siguientes:

- Los artículo de la Ley del Servicio Civil relacionados a la Negociación Colectiva (40 al 45) al establecer prohibición a las organizaciones sindicales de servidores públicos negociar con su empleador condiciones remunerativas y económicas afectan derechos fundamentales de éstos establecidos en la Constitución política del Estado. Esto ha sido confirmado por el Tribunal Constitucional en sendas sentencias emitidas declarando la constitucionalidad de las mismas..

- El Derecho a la Negociación Colectiva de los servidores públicos tiene fundamento constitucional, no obstante que no haya sido considerado expresamente en el artículo 42 de la Constitución Política del Estado. Ya el Tribunal Constitucional, en reiterada jurisprudencia, ha expresado el Derecho a la Negociación Colectiva se encuentra colectivo en el derecho de Sindicalización del artículo 42 de la Carta Magna, así como también en el artículo 28 que establece este derecho para todos los trabajadores sin excepción alguna, entre ellos a los trabajadores del estado.

- El Derecho a la Negociación Colectiva se encuentra garantizado por los Convenios 87,98 y 151 de la Organización Internacional del Trabajo, de manera vinculante para todos los Estados que haya ratificado dichos convenios.

- El marco teórico que explica la relación entre el Estado Empleador y los Servidores Públicos son dos: la Teoría Estatutaria, donde hay predominio del Estado y en la que el servidor solamente tiene que subordinarse y aceptar las condiciones que éste establece, y la Teoría Contractualista (laboral), cuya relación reconoce que los servidores públicos también son trabajadores y por lo tanto se le reconocen todos los derechos laborales. y la posibilidad de negociar cuestiones remunerativas y económicas. En la teoría estatutaria se han basado los criterios que proponían disminuir derechos, en especial la prohibición de negociar remuneraciones a los servidores públicos por razones presupuestales. En ese sentido contrario, la teoría 
contractualista propone que los servidores públicos son trabajadores, por tanto se le deben reconocer todos los derechos laborales sin excepción.

- Los fundamentos presupuestales que justificarían la afectación de derechos fundamentales de los servidores públicos se encuentran regulados en loa artículos 77 y 78 de la Constitución Política, en lo relacionado a Provisión Presupuestaria. Al respecto el Tribunal Constitucional se ha pronunciado en el sentido que no existe colisión con el derecho a la Negociación Colectiva, así el producto de está (el acuerdo) se considera en el siguiente periodo presupuestario para su aprobación. 


\section{RECOMENDACIONES}

- Aspectos generales: La presente investigación considera que el Parlamento debe emitir normas legales a efectos de aplicar el contenido de la sentencia del Tribunal Constitucional en lo que respecta a la negociación colectiva en materia salarial y económica de los servidores públicos, la misma que debe contener, en mi opinión los siguientes aspectos:

- Previsibilidad del gasto en materia de personal: Si bien la sentencia del tribunal propone que los montos económicos acordados en las convenciones colectivas del sector público deben ser aprobados por el Congreso para el siguiente año presupuestario, existe una segunda alternativa que es de menor impacto pero de mayor previsibilidad en el gasto y consisten en que el parlamento pueda aprobar montos límites en el presupuesto de la república para gastos de personal en forma previa y para años futuros.

De tal manera la negociación normativa tendría un techo o límite para que las exigencias de los servidores públicos no se puedan desbordar y se mantenga a salvo de contingencias las arcas fiscales del Estado peruano. Dicha propuesta coincide con el principio de provisión presupuestaria establecido en la Constitución Política del Estado.

- Exigibilidad de entregar el balance presupuestario a los sindicatos a efectos de sincerar los pliegos - exigencia: Para una adecuada negociación colectiva en materia económica es indispensable que las partes, especialmente el Estado empleador debe proporcionar importante información económica y/o financiera al sindicato para que ésta pueda sincerar sus pretensiones y elaborar un pliego de reclamos adaptado a la situación real de la economía del Estado peruano. Esto coindice por la recomendación hecha por la OIT en su reciente estudio "La negociación Colectiva en la Administración Pública, Un camino a seguir". Conferencia Internacional del Trabajo - 102va reunión.

Considero que para mantener cierta autonomía y confiabilidad en los informes o dictámenes de orden económico, las autoridades que se pronunciaría sobre estas materias con respecto a la negociación colectiva en la administración pública serian: 
- El Consejo Fiscal, creado por la Ley 30099, Ley del Fortalecimiento de la Responsabilidad y Transparencia Fiscal, adscrito al Ministerio de Economía y Finanzas, pero con autonomía funcional, y

- el Banco Central de Reserva del Perú, organismo constitucionalmente autónomo.

- Procedimiento en el ámbito nacional de la negociación colectiva: La negociación en la Administración Pública deberá realizarse en el ámbito nacional a través de los organismos de tercer grado de las organizaciones sindicales de servidores públicos (una Central o Confederación) quienes designarán seis (6) representantes y una la representación multisectorial del Estado peruano a través de las siguientes instituciones:

- Un representante de la Presidencia del Consejo de Ministros.

- Un representante del Ministerio de Trabajo.

- Un representante del Ministerio de Economía y Finanzas.

- Un representante del Ministerio de Justicia y Derechos Humanos.

- Un representante del Poder Judicial.

- Un representante del Poder Legislativo

La Autoridad Nacional del Servicio Civil realizará la labor de la Secretaría Técnica.

Consideramos importante la presencia de los representantes del poder Legislativo y del Poder Judicial porque en el primer caso, además de tener gran población de servidores civiles, es el organismo que aprobaría a los acuerdos de la convención colectiva dentro del procedimiento presupuestario establecido en la Constitución política del Estado. El Poder Judicial garantizaría que los procesos de negociación en este nivel cumplan con las exigencias legales correspondientes.

Las partes antes descritas negociaran a nivel nacional una convención colectiva que tenga como un solo tema el carácter remunerativo. Considero que por ser una materia de carácter presupuestal y financiero, éstas negociaciones se deben realizar cada tres años a efectos de mantener una paz social y gobernabilidad prudente y evitar así que los servidores civiles no se distraigan en las importantes funciones de servicios a la ciudadanía

- Procedimiento en el ámbito nacional: 
1. El procedimiento de la negociación económica en el ámbito nacional sólo tendría dos etapas: La negociación directa. Si esta fracasa los servidores públicos tendrían que optar por la huelga o por acudir al Consejo Nacional de Concertación Económica de la Administración Pública.

La negociación directa tendría tres sub-etapas:

i) Primera. Instalación y presentación de demanda económica.

ii) Análisis y debate sobre los informes económicos emitidos por el Consejo Fiscal y el Banco Central de Reserva.

iii) Toma de acuerdos finales.

\section{En caso fracase la negociación directa}

En caso fracase la negociación directa los servidores públicos podrán optar por la huelga con los requisitos establecidos en la Ley 30057 u optar por acudir al Consejo Nacional de Concertación Económica de la Administración Pública, el cual estaría integrada por:

- El Presidente de la Corte Suprema de la República, quien la presidirá.

- El Presidente del Consejo de Ministros.

- El Presidente del Congreso de la República.

- El Presidente del Banco Central de Reserva.

- El Defensor del Pueblo.

- El Presidente de la Asamblea Nacional de Gobiernos Regionales. y

- El Presidente de la Asociación Nacional de Colegios Profesionales del Perú.

Dicho Consejo sería convocado por el Presidente de la Corte Suprema de la República y funcionaría de la siguiente manera:

Tendría sólo tres sesiones:

i) En la primera se tomaría conocimiento de las propuestas de las partes.

ii) En la segunda se actuarían los informes orales y se analizarían los informes económicos. Y

iii) En la tercera se emitiría la Resolución final, en la que se optaría por la propuesta final de las partes que sea más razonable dando solución definitiva y de carácter vinculante para las partes, 
- Procedimiento de negociación colectiva a nivel de entidades públicas: En el ámbito de las entidades públicas tipo A, se podrán llevar a cabo negociaciones colectivas entre los sindicatos del mismo y del titular o sus representantes, dicha negociación abarcará sólo las condiciones de empleo sin considerar las condiciones económicas.

Este convenio tendrá la duración de dos años, de conformidad a lo establecido en el literal d) del artículo 44 de la Ley del Servicio Civil - Ley 30057. 


\section{REFERENCIAS}

Balbin Torres, E., (2008). Sobre el Derecho de Negociación Colectiva de los

Trabajadores Estatales y la normatividad Presupuestal. Lima: Editorial Grijley.

Balbin Torres, E., (2005) Unilateralismo y Negociación Colectiva en la Administración Pública. Lima: Fondo Editorial de la Pontificia Universidad Católica del Perú.

Bielsa, R.,. (1956). Derecho Administrativo. 5ta Edición. Tomo III. Buenos Aires: Roque Desalma Editor,

Bueno Magano, O., (1993). Direito Colectivo do Trabalho. San Paulo, LTR.

Cabanellas De Torres, G., (2002). Diccionario Jurídico Elemental. Buenos Aires: Edit. Eliasta.

Cortés Carcelén, J. C. (2006) La huelga en los servicios esenciales y el Decreto Ley 25593. Themis 26

Haro Carranza, J. E. (2014). SERVIR: El nuevo régimen del Servicio Civil en la administración pública. Lima: Ediciones Legales.

Haro Carranza, J.,. (2012). Derecho Laboral Público. Lima: Ediciones Legales.

Martinez Vivot, J., (1996). Elementos del Derecho de Trabajo y de la Seguridad Social. Buenos Aires: Editorial Astrea.

Martínez Trelles A. (2014). Manual del servicio civil y régimen laboral Público. Lima: Gaceta Jurídica.

Miranda Hurtado, G., (2004) Instituciones y Perspectivas del Derecho Laboral Público. Derecho y Sociedad. Año XV, 23 - PUCP

Morales Corrales. P., (2008). La Negociación Colectiva en Entidades del Sector Público, en estudios Jurídicos en Homenaje a Luis Aparicio Valdez. Lima: Editoral GRIJLEY.

Patron Faura, P., Patron Bedoya, P.,.(2004). Derecho Administrativo y Administración Pública en el Perú. Lima: Editora Jurídica Grijley.

Prats I Catalá. (1999) “Servicio Civil y Gobernabilidad Democrática: Fundamentos institucionales del sistema de mérito y régimen jurídicos y gerenciales requeridos para su eficiencia”. ¿De Burócratas a Gerentes? Las ciencias de la gestión aplicadas a la administración del Estado. Washington D.C.

Sánchez Morón, M., (1997) Derecho de la función pública. Segunda Edición. Editorial Tecnos, 
Villavicencio Rios (2004). El Principio de Autonomía Colectiva, en Los Principios del Derecho del Trabajo. Homenaje al profesor Américo Pla Rodríguez. Sociedad Peruana del Derecho del Trabajo. Lima: EditorialAli Arte Gráfico.

Villarroel, A. (2005). Situación actual comparada de las relaciones laborales en el sector público de 9 países de América Latina. Oficina Internacional del Trabajo.

.Avalos Jara, O. (2015). Particularidades de la Negociación Colectiva en el Sector Público. Universidad de Lima. Recuperado 9 de abril de 2016 de: http://webcache.googleusercontent.com/search?q=cache:auJgCvuUWIJ:www.trabajo.gob.pe/boletin/documentos/boletin_43/doc_boletin_43_1.p $\mathrm{df}+\& \mathrm{~cd}=1 \& \mathrm{hl}=\mathrm{es} \& \mathrm{ct}=\mathrm{clnk} \& \mathrm{gl}=\mathrm{pe}$

Beltran Larco, P. (2013). Problemática de la existencia de distintos regímenes de contratación de personal en el Estado, Tesis para optar el grado de maestro, de la Escuela de Postgrado de la Pontificia Universidad Católica del Perú. Recuperado el 9 de abril de 2016 de: http://tesis.pucp.edu.pe/repositorio/bitstream/handle/123456789/4508/BELTRA $\underline{\mathrm{N}}$ _LARCO_LUISA_CONTRATACION_PERSONAL.pdf?sequence $=1$

Ciudad Reynaud, A. (2014). Inconstitucionalidad de la Ley del Servicio Civil. Revista IDEELE. Revista $\mathrm{N}^{\circ} 246$. Recuperado el 12 de abril de 2016 de http://revistaideele.com/ideele/content/la-inconstitucionalidad-de-la-ley-del-serviciocivil

Oficina Internacional del Trabajo (2013). La negociación Colectiva en la Administración Pública, Un camino a seguir. Conferencia Internacional del Trabajo, 102va reunión. Ginebra. (recuperado en 20 de junio de 2016.)

Orsatti, Á. y Rubiano, C. (2014) Organización y negociación colectiva de los trabajadores del sector público en América Latina: normas y prácticas sindicales. Recuperado el 9 de abril de 2016 de: http://www.ctmargentina.org/pdfs/3-OrganizacionynegociacioncolectivasectorpublicoAL.pdf

Lopez Gomez, J. La Negociacion Colectiva en el Sector Público Dirección de Recursos Humanos Universidad de Sevilla. Recuperado el 9 de abril de 2016 de: http://personal.us.es/jmlopezgomez/uploads/jmlg/revistas/negociacioncolectiva. pdf 


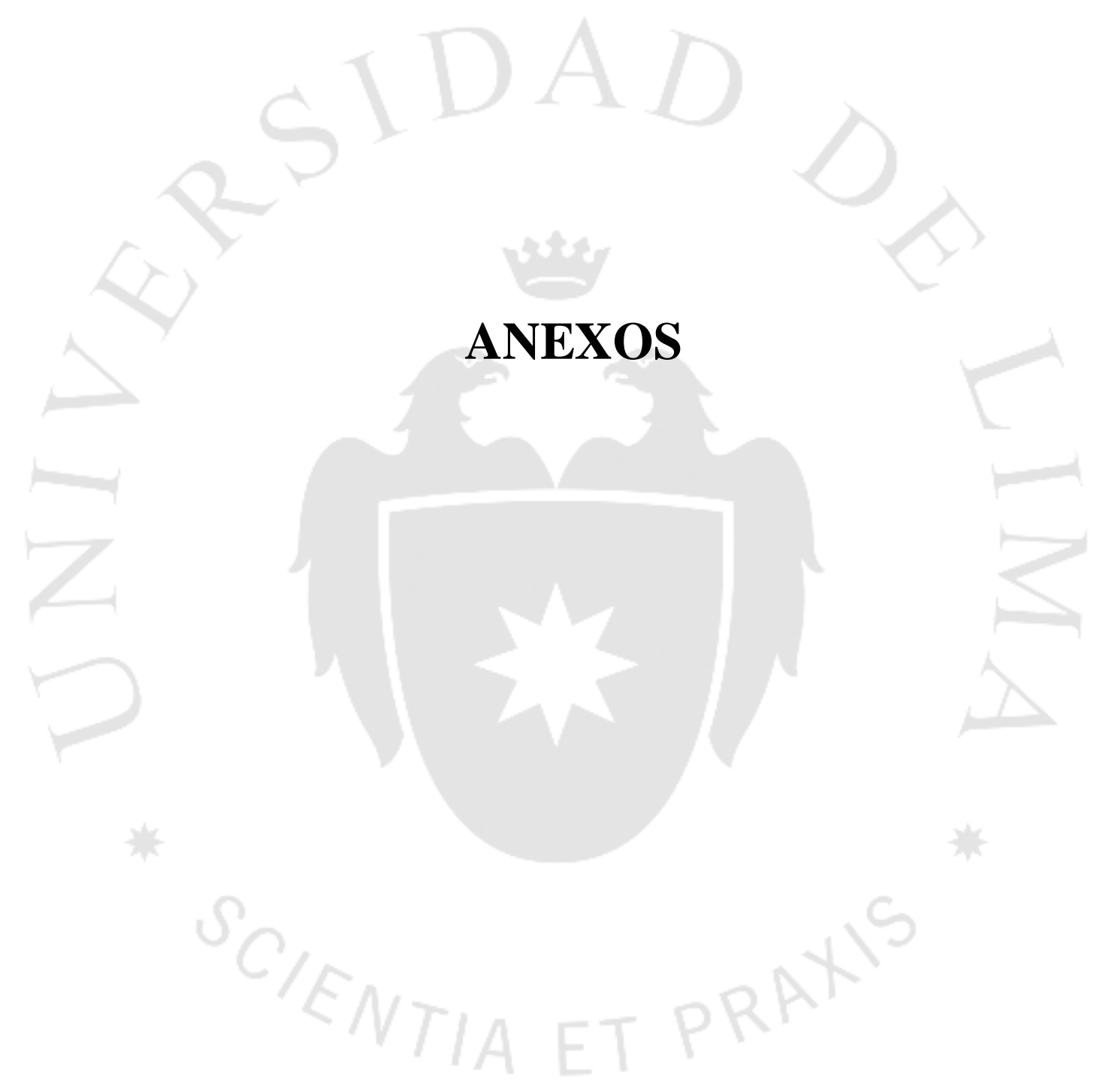




\section{Anexo 1: Convenio $\mathbf{N}^{\circ} 087$ de la Organización Internacional De Trabajo. Convenio relativo a la libertad sindical y a la protección del derecho de sindicación.}

Convenio relativo a la libertad sindical y a la protección del derecho de sindicación (Nota: Fecha de entrada en vigor: 04:07:1950)

Lugar:(San Francisco)

Fecha de adopción: 09:07: 1948

Sesión de la Conferencia: 31

Estatus: Instrumento actualizado Este instrumento hace parte de los convenios fundamentales.

La Conferencia General de la Organización Internacional del Trabajo:

Convocada en San Francisco por el Consejo de Administración de la Oficina Internacional del Trabajo, y congregada en dicha ciudad el 17 junio 1948 en su trigésima primera reunión;

Después de haber decidido adoptar, en forma de convenio, diversas proposiciones relativas a la libertad sindical y a la protección del derecho de sindicación, cuestión que constituye el séptimo punto del orden del día de la reunión;

Considerando que el preámbulo de la Constitución de la Organización Internacional del Trabajo enuncia, entre los medios susceptibles de mejorar las condiciones de trabajo y de garantizar la paz, "la afirmación del principio de la libertad de asociación sindical";

Considerando que la Declaración de Filadelfia proclamó nuevamente que "la libertad de expresión y de asociación es esencial para el progreso constante";

Considerando que la Conferencia Internacional del Trabajo, en su trigésima reunión, adoptó por unanimidad los principios que deben servir de base a la reglamentación internacional, y

Considerando que la Asamblea General de las Naciones Unidas, en su segundo período de sesiones, hizo suyos estos principios y solicitó de la Organización Internacional del Trabajo la continuación de todos sus esfuerzos a fin de hacer posible la adopción de uno o varios convenios internacionales,

adopta, con fecha nueve de julio de mil novecientos cuarenta y ocho, el siguiente Convenio, que podrá ser citado como el Convenio sobre la libertad sindical y la protección del derecho de sindicación, 1948:

Parte I. Libertad Sindical

Artículo 1

Todo Miembro de la Organización Internacional del Trabajo para el cual esté en vigor el presente Convenio se obliga a poner en práctica las disposiciones siguientes.

Artículo 2

Los trabajadores y los empleadores, sin ninguna distinción y sin autorización previa, tienen el derecho de constituir las organizaciones que estimen convenientes, así como el de afiliarse a estas organizaciones, con la sola condición de observar los estatutos de las mismas.

Artículo 3

1. Las organizaciones de trabajadores y de empleadores tienen el derecho de redactar sus estatutos y reglamentos administrativos, el de elegir libremente sus representantes, el de organizar su administración y sus actividades y el de formular su programa de acción.

2. Las autoridades públicas deberán abstenerse de toda intervención que tienda a limitar este derecho o a entorpecer su ejercicio legal.

Artículo 4

Las organizaciones de trabajadores y de empleadores no están sujetas a disolución o suspensión por vía administrativa.

Artículo 5 
Las organizaciones de trabajadores y de empleadores tienen el derecho de constituir federaciones y confederaciones, así como el de afiliarse a las mismas, y toda organización, federación o confederación tiene el derecho de afiliarse a organizaciones internacionales de trabajadores y de empleadores.

\section{Artículo 6}

Las disposiciones de los artículos 2, 3 y 4 de este Convenio se aplican a las federaciones y confederaciones de organizaciones de trabajadores y de empleadores.

\section{Artículo 7}

La adquisición de la personalidad jurídica por las organizaciones de trabajadores y de empleadores, sus federaciones y confederaciones no puede estar sujeta a condiciones cuya naturaleza limite la aplicación de las disposiciones de los artículos 2, 3 y 4 de este Convenio

\section{Artículo 8}

1. Al ejercer los derechos que se les reconocen en el presente Convenio, los trabajadores, los empleadores y sus organizaciones respectivas están obligados, lo mismo que las demás personas o las colectividades organizadas, a respetar la legalidad.

2. La legislación nacional no menoscabará ni será aplicada de suerte que menoscabe las garantías previstas por el presente Convenio.

Artículo 9

1. La legislación nacional deberá determinar hasta qué punto se aplicarán a las fuerzas armadas y a la policía las garantías previstas por el presente Convenio.

2. De conformidad con los principios establecidos en el párrafo 8 del artículo 19 de la Constitución de la Organización Internacional del Trabajo, no deberá considerarse que la ratificación de este Convenio por un Miembro menoscaba en modo alguno las leyes, sentencias, costumbres o acuerdos ya existentes que concedan a los miembros de las fuerzas armadas y de la policía garantías prescritas por el presente Convenio.

Artículo 10

En el presente Convenio, el término organización significa toda organización de trabajadores o de empleadores que tenga por objeto fomentar y defender los intereses de los trabajadores o de los empleadores.

Parte II. Protección del Derecho de Sindicación

Artículo 11

Todo Miembro de la Organización Internacional del Trabajo para el cual esté en vigor el presente Convenio se obliga a adoptar todas las medidas necesarias y apropiadas para garantizar a los trabajadores y a los empleadores el libre ejercicio del derecho de sindicación.

\section{Parte III. Disposiciones Diversas}

\section{Artículo 12}

1. Respecto de los territorios mencionados en el artículo 35 de la Constitución de la Organización Internacional del Trabajo, enmendada por el Instrumento de enmienda a la Constitución de la Organización Internacional del Trabajo, 1946, excepción hecha de los territorios a que se refieren los párrafos 4 y 5 de dicho artículo, tal como quedó enmendado, todo Miembro de la Organización que ratifique el presente Convenio deberá comunicar al Director General de la Oficina Internacional del Trabajo, en el plazo más breve posible después de su ratificación, una declaración en la que manifieste:

a) los territorios respecto de los cuales se obliga a que las disposiciones del Convenio sean aplicadas sin modificaciones;

b) los territorios respecto de los cuales se obliga a que las disposiciones del Convenio sean aplicadas con modificaciones, junto con los detalles de dichas modificaciones;

c) los territorios respecto de los cuales es inaplicable el Convenio y los motivos por los que es inaplicable;

d) los territorios respecto de los cuales reserva su decisión.

2. Las obligaciones a que se refieren los apartados a) y b) del párrafo 1 de este artículo se considerarán parte integrante de la ratificación y producirán sus mismos efectos.

3. Todo Miembro podrá renunciar, total o parcialmente, por medio de una nueva declaración, a cualquier reserva formulada en su primera declaración en virtud de los apartados b), c) o d) del párrafo 1 de este artículo.

4. Durante los períodos en que este Convenio pueda ser denunciado, de conformidad con las disposiciones del 
artículo 16, todo Miembro podrá comunicar al Director General una declaración por la que modifique, en cualquier otro aspecto, los términos de cualquier declaración anterior y en la que indique la situación en territorios determinados.

\section{Artículo 13}

1. Cuando las cuestiones tratadas en el presente Convenio sean de la competencia de las autoridades de un territorio no metropolitano, el Miembro responsable de las relaciones internacionales de ese territorio, de acuerdo con el gobierno del territorio, podrá comunicar al Director General de la Oficina Internacional del Trabajo una declaración por la que acepte, en nombre del territorio, las obligaciones del presente Convenio.

2. Podrán comunicar al Director General de la Oficina Internacional del Trabajo una declaración por la que se acepten las obligaciones de este Convenio:

a) dos o más Miembros de la Organización, respecto de cualquier territorio que esté bajo su autoridad común; o

b) toda autoridad internacional responsable de la administración de cualquier territorio, en virtud de las disposiciones de la Carta de las Naciones Unidas o de cualquier otra disposición en vigor, respecto de dicho territorio.

3. Las declaraciones comunicadas al Director General de la Oficina Internacional del Trabajo, de conformidad con los párrafos precedentes de este artículo, deberán indicar si las disposiciones del Convenio serán aplicadas en el territorio interesado con modificaciones o sin ellas; cuando la declaración indique que las disposiciones del Convenio serán aplicadas con modificaciones, deberá especificar en qué consisten dichas modificaciones.

4. El Miembro, los Miembros o la autoridad internacional interesados podrán renunciar, total o parcialmente, por medio de una declaración ulterior, al derecho a invocar una modificación indicada en cualquier otra declaración anterior.

5. Durante los períodos en que este Convenio pueda ser denunciado de conformidad con las disposiciones del artículo 16, el Miembro, los Miembros o la autoridad internacional interesados podrán comunicar al Director General una declaración por la que modifiquen, en cualquier otro respecto, los términos de cualquier declaración anterior y en la que indiquen la situación en lo que se refiere a la aplicación del Convenio.

\section{Parte IV. Disposiciones Finales}

Artículo 14

Las ratificaciones formales del presente Convenio serán comunicadas, para su registro, al Director General de la Oficina Internacional del Trabajo.

Artículo 15

1. Este Convenio obligará únicamente a aquellos Miembros de la Organización Internacional del Trabajo cuyas ratificaciones haya registrado el Director General.

2. Entrará en vigor doce meses después de la fecha en que las ratificaciones de dos Miembros hayan sido registradas por el Director General.

3. Desde dicho momento, este Convenio entrará en vigor, para cada Miembro, doce meses después de la fecha en que haya sido registrada su ratificación.

\section{Artículo 16}

1. Todo Miembro que haya ratificado este Convenio podrá denunciarlo a la expiración de un período de diez años, a partir de la fecha en que se haya puesto inicialmente en vigor, mediante un acta comunicada, para su registro, al Director General de la Oficina Internacional del Trabajo. La denuncia no surtirá efecto hasta un año después de la fecha en que se haya registrado.

2. Todo Miembro que haya ratificado este Convenio y que, en el plazo de un año después de la expiración del período de diez años mencionado en el párrafo precedente, no haga uso del derecho de denuncia previsto en este artículo quedará obligado durante un nuevo período de diez años, y en lo sucesivo podrá denunciar este Convenio a la expiración de cada período de diez años en las condiciones previstas en este artículo.

\section{Artículo 17}

1. El Director General de la Oficina Internacional del Trabajo notificará a todos los Miembros de la Organización Internacional del Trabajo el registro de cuantas ratificaciones, declaraciones y denuncias le comuniquen los Miembros de la Organización.

2. Al notificar a los Miembros de la Organización el registro de la segunda ratificación que le haya sido comunicada, el Director General llamará la atención de los Miembros de la Organización sobre la fecha en que entrará en vigor el presente Convenio.

Artículo 18

El Director General de la Oficina Internacional del Trabajo comunicará al Secretario General de las Naciones 
Unidas, a los efectos del registro y de conformidad con el artículo 102 de la Carta de las Naciones Unidas, una información completa sobre todas las ratificaciones, declaraciones y actas de denuncia que haya registrado de acuerdo con los artículos precedentes.

\section{Artículo 19}

A la expiración de cada período de diez años, a partir de la fecha en que este Convenio entre en vigor, el Consejo de Administración de la Oficina Internacional del Trabajo deberá presentar a la Conferencia General una memoria sobre la aplicación de este Convenio, y deberá considerar la conveniencia de incluir en el orden del día de la Conferencia la cuestión de la revisión total o parcial del mismo.

\section{Artículo 20}

1. En caso de que la Conferencia adopte un nuevo convenio que implique una revisión total o parcial del presente, y a menos que el nuevo convenio contenga disposiciones en contrario:

a) la ratificación, por un Miembro, del nuevo convenio revisor implicará, ipso jure, la denuncia inmediata de este Convenio, no obstante las disposiciones contenidas en el artículo 16, siempre que el nuevo convenio revisor haya entrado en vigor;

b) a partir de la fecha en que entre en vigor el nuevo convenio revisor, el presente Convenio cesará de estar abierto a la ratificación por los Miembros.

2. Este Convenio continuará en vigor en todo caso, en su forma y contenido actuales, para los Miembros que lo hayan ratificado y no ratifiquen el convenio revisor.

\section{Artículo 21}

Las versiones inglesa y francesa del texto de este Convenio son igualmente auténticas.

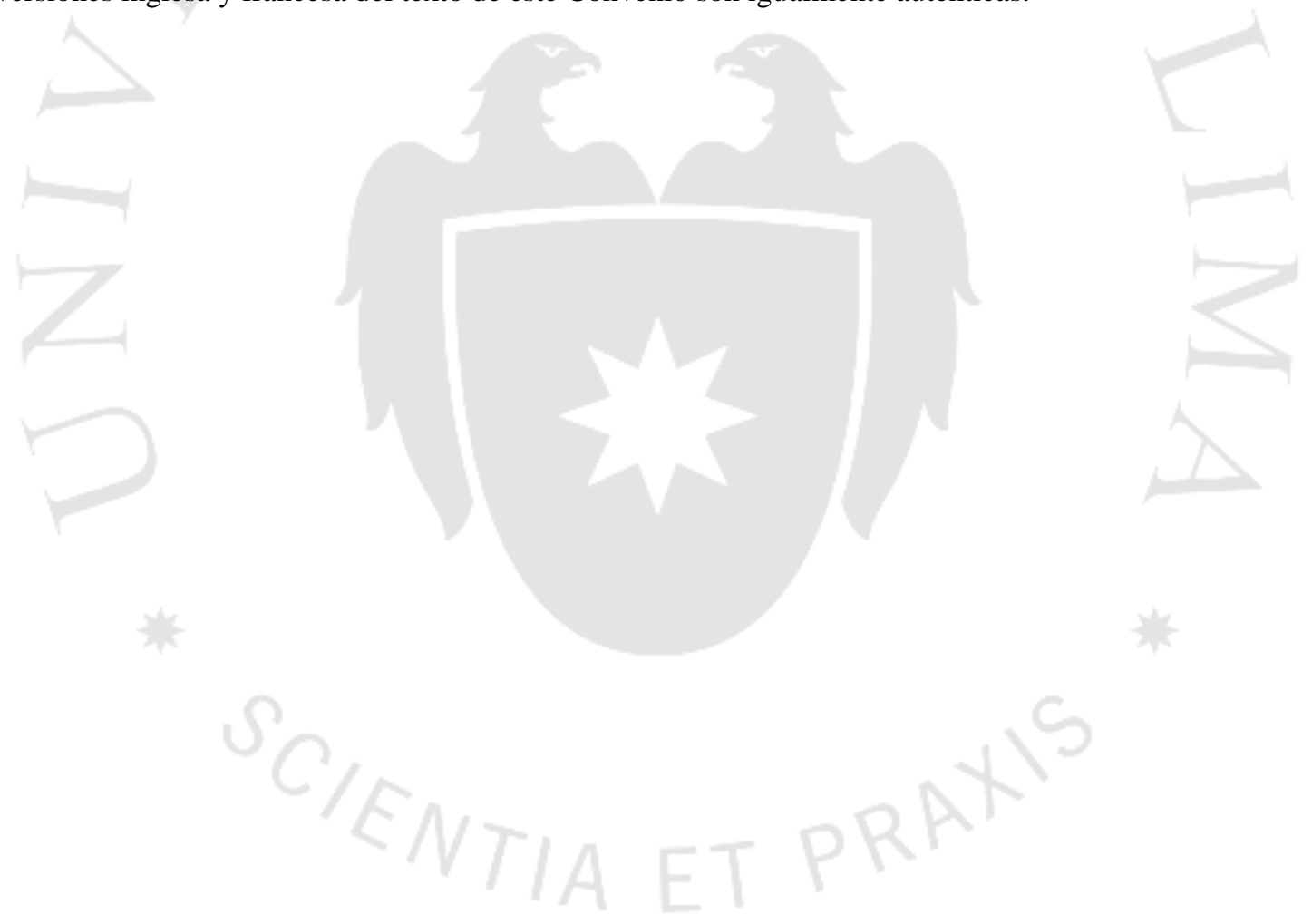




\section{Anexo 2: Convenio $\mathbf{N}^{\circ} 98$ de la OIT.}

Convenio relativo a la aplicación de los principios del derecho de sindicación y de negociación colectiva (Nota: Fecha de entrada en vigor: 18:07:1951)

Lugar: Ginebra

Fecha de adopción: 01:07:1949

Sesión de la Conferencia: 32

Estatus: Instrumento actualizado Este instrumento hace parte de los convenios fundamentales.

La Conferencia General de la Organización Internacional del Trabajo:

Convocada en Ginebra por el Consejo de Administración de la Oficina Internacional del Trabajo, y congregada en dicha ciudad el 8 junio 1949 en su trigésima segunda reunión;

Después de haber decidido adoptar diversas proposiciones relativas a la aplicación de los principios del derecho de sindicación y de negociación colectiva, cuestión que constituye el cuarto punto del orden del día de la reunión, y después de haber decidido que dichas proposiciones revistan la forma de un convenio internacional, adopta, con fecha primero de julio de mil novecientos cuarenta y nueve, el siguiente Convenio, que podrá ser citado como el Convenio sobre el derecho de sindicación y de negociación colectiva, 1949:

Artículo 1

1. Los trabajadores deberán gozar de adecuada protección contra todo acto de discriminación tendiente a menoscabar la libertad sindical en relación con su empleo.

2. Dicha protección deberá ejercerse especialmente contra todo acto que tenga por objeto:

a) sujetar el empleo de un trabajador a la condición de que no se afilie a un sindicato o a la de dejar de ser miembro de un sindicato;

b) despedir a un trabajador o perjudicarlo en cualquier otra forma a causa de su afiliación sindical o de su participación en actividades sindicales fuera de las horas de trabajo o, con el consentimiento del empleador, durante las horas de trabajo.

Artículo 2

1. Las organizaciones de trabajadores y de empleadores deberán gozar de adecuada protección contra todo acto de injerencia de unas respecto de las otras, ya se realice directamente o por medio de sus agentes o miembros, en su constitución, funcionamiento o administración.

2. Se consideran actos de injerencia, en el sentido del presente artículo, principalmente, las medidas que tiendan a fomentar la constitución de organizaciones de trabajadores dominadas por un empleador o una organización de empleadores, o a sostener económicamente, o en otra forma, organizaciones de trabajadores, con objeto de colocar estas organizaciones bajo el control de un empleador o de una organización de empleadores.

Artículo 3

Deberán crearse organismos adecuados a las condiciones nacionales, cuando ello sea necesario, para garantizar el respeto al derecho de sindicación definido en los artículos precedentes.

Artículo 4

Deberán adoptarse medidas adecuadas a las condiciones nacionales, cuando ello sea necesario, para estimular y fomentar entre los empleadores y las organizaciones de empleadores, por una parte, y las organizaciones de trabajadores, por otra, el pleno desarrollo y uso de procedimientos de negociación voluntaria, con objeto de reglamentar, por medio de contratos colectivos, las condiciones de empleo.

\section{Artículo 5}

1. La legislación nacional deberá determinar el alcance de las garantías previstas en el presente Convenio en lo que se refiere a su aplicación a las fuerzas armadas y a la policía.

2. De acuerdo con los principios establecidos en el párrafo 8 del artículo 19 de la Constitución de la Organización Internacional del Trabajo, la ratificación de este Convenio por un Miembro no podrá considerarse que menoscaba en modo alguno las leyes, sentencias, costumbres o acuerdos ya existentes, que concedan a los miembros de las fuerzas armadas y de la policía las garantías prescritas en este Convenio.

Artículo 6

El presente Convenio no trata de la situación de los funcionarios públicos en la administración del Estado y no deberá interpretarse, en modo alguno, en menoscabo de sus derechos o de su estatuto. 
Artículo 7

Las ratificaciones formales del presente Convenio serán comunicadas, para su registro, al Director General de la Oficina Internacional del Trabajo.

Artículo 8

1. Este Convenio obligará únicamente a aquellos Miembros de la Organización Internacional del Trabajo cuyas ratificaciones haya registrado el Director General.

2. Entrará en vigor doce meses después de la fecha en que las ratificaciones de dos Miembros hayan sido registradas por el Director General.

3. Desde dicho momento, este Convenio entrará en vigor, para cada Miembro, doce meses después de la fecha en que haya sido registrada su ratificación.

Artículo 9

1. Las declaraciones comunicadas al Director General de la Oficina Internacional del Trabajo, de acuerdo con el párrafo 2 del artículo 35 de la Constitución de la Organización Internacional del Trabajo, deberán indicar:

a) los territorios respecto de los cuales el Miembro interesado se obliga a que las disposiciones del Convenio sean aplicadas sin modificaciones;

b) los territorios respecto de los cuales se obliga a que las disposiciones del Convenio sean aplicadas con modificaciones, junto con los detalles de dichas modificaciones;

c) los territorios respecto de los cuales es inaplicable el Convenio y los motivos por los cuales es inaplicable;

d) los territorios respecto de los cuales reserva su decisión en espera de un examen más detenido de su situación.

2. Las obligaciones a que se refieren los apartados a) y b) del párrafo 1 de este artículo se considerarán parte integrante de la ratificación y producirán sus mismos efectos.

3. Todo Miembro podrá renunciar, total o parcialmente, por medio de una nueva declaración, a cualquier reserva formulada en su primera declaración en virtud de los apartados b), c) o d) del párrafo 1 de este artículo.

4. Durante los períodos en que este Convenio pueda ser denunciado de conformidad con las disposiciones del artículo 11, todo Miembro podrá comunicar al Director General una declaración por la que modifique, en cualquier otro respecto, los términos de cualquier declaración anterior y en la que indique la situación en territorios determinados.

Artículo 10

1. Las declaraciones comunicadas al Director General de la Oficina Internacional del Trabajo, de conformidad con los párrafos 4 y 5 del artículo 35 de la Constitución de la Organización Internacional del Trabajo, deberán indicar si las disposiciones del Convenio serán aplicadas en el territorio interesado con modificaciones o sin ellas; cuando la declaración indique que las disposiciones del Convenio serán aplicadas con modificaciones, deberá especificar en qué consisten dichas modificaciones.

2. El Miembro, los Miembros o la autoridad internacional interesados podrán renunciar, total o parcialmente, por medio de una declaración ulterior, al derecho a invocar una modificación indicada en cualquier otra declaración anterior.

3. Durante los períodos en que este Convenio puede ser denunciado de conformidad con las disposiciones del artículo 11, el Miembro, los Miembros o la autoridad internacional interesados podrán comunicar al Director General una declaración por la que modifiquen, en cualquier otro respecto, los términos de cualquier declaración anterior y en la que indiquen la situación en lo que se refiere a la aplicación del Convenio.

Artículo 11

1. Todo Miembro que haya ratificado este Convenio podrá denunciarlo a la expiración de un período de diez años, a partir de la fecha en que se haya puesto inicialmente en vigor, mediante un acta comunicada, para su registro, al Director General de la Oficina Internacional del Trabajo. La denuncia no surtirá efecto hasta un año después de la fecha en que se haya registrado.

2. Todo Miembro que haya ratificado este Convenio y que, en el plazo de un año después de la expiración del período de diez años mencionado en el párrafo precedente, no haga uso del derecho de denuncia previsto en este artículo quedará obligado durante un nuevo período de diez años, y en lo sucesivo podrá denunciar este Convenio a la expiración de cada período de diez años, en las condiciones previstas en este artículo. 
Artículo 12

1. El Director General de la Oficina Internacional del Trabajo notificará a todos los Miembros de la Organización Internacional del Trabajo el registro de cuantas ratificaciones, declaraciones y denuncias le comuniquen los Miembros de la Organización.

2. Al notificar a los Miembros de la Organización el registro de la segunda ratificación que le haya sido comunicada, el Director General llamará la atención de los Miembros de la Organización sobre la fecha en que entrará en vigor el presente Convenio.

\section{Artículo 13}

El Director General de la Oficina Internacional del Trabajo comunicará al Secretario General de las Naciones Unidas, a los efectos del registro y de conformidad con el artículo 102 de la Carta de las Naciones Unidas, una información completa sobre todas las ratificaciones, declaraciones y actas de denuncia que haya registrado de acuerdo con los artículos precedentes.

Artículo 14

Cada vez que lo estime necesario, el Consejo de Administración de la Oficina Internacional del Trabajo presentará a la Conferencia General una memoria sobre la aplicación del Convenio y considerará la conveniencia de incluir en el orden del día de la Conferencia la cuestión de su revisión total o parcial.

\section{Artículo 15}

1. En caso de que la Conferencia adopte un nuevo convenio que implique una revisión total o parcial del presente, y a menos que el nuevo convenio contenga disposiciones en contrario:

a) la ratificación, por un Miembro, del nuevo convenio revisor implicará, ipso jure, la denuncia inmediata de este Convenio, no obstante las disposiciones contenidas en el artículo 11, siempre que el nuevo convenio revisor haya entrado en vigor;

b) a partir de la fecha en que entre en vigor el nuevo convenio revisor, el presente Convenio cesará de estar abierto a la ratificación por los Miembros.

2. Este Convenio continuará en vigor en todo caso, en su forma y contenido actuales, para las Miembros que lo hayan ratificado y no ratifiquen el convenio revisor.

Artículo 16

Las versiones inglesa y francesa del texto de este Convenio son igualmente auténticas.

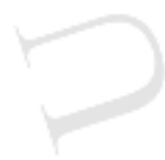




\section{Anexo $\mathbf{N}^{\circ}$ 3: Convenio $\mathbf{N}^{\circ} 151$ de la OIT Sobre las relaciones de trabajo en la administración pública, 1978}

Sobre las relaciones de trabajo en la administración pública, 1978

Convenio sobre la protección del derecho de sindicación y los procedimientos para determinar las condiciones de empleo en la administración pública (Nota: Fecha de entrada en vigor: 25:02:1981 .)

Lugar:Ginebra

Fecha de adopción:27:06:1978

Sesion de la Conferencia:64

Estatus: Instrumento actualizado que ha sido objeto de una solicitud de información La Conferencia General de la Organización Internacional del Trabajo:

Convocada en Ginebra por el Consejo de Administración de la Oficina Internacional del Trabajo, y congregada en dicha ciudad el 7 junio 1978 en su sexagésima cuarta reunión;

Recordando las disposiciones del Convenio sobre la libertad sindical y la protección del derecho de sindicación, 1948; del Convenio sobre el derecho de sindicación y de negociación colectiva, 1949, y del Convenio y la Recomendación sobre los representantes de los trabajadores, 1971;

Recordando que el Convenio sobre el derecho de sindicación y de negociación colectiva, 1949, no es aplicable a ciertas categorías de empleados públicos y que el Convenio y la Recomendación sobre los representantes de los trabajadores, 1971, se aplican a los representantes de los trabajadores en la empresa;

Tomando nota de la considerable expansión de los servicios prestados por la administración pública en muchos países y de la necesidad de que existan sanas relaciones laborales entre las autoridades públicas y las organizaciones de empleados públicos;

Observando la gran diversidad de los sistemas políticos, sociales y económicos de los Estados Miembros y las diferentes prácticas aplicadas por dichos Estados (por ejemplo, en lo atinente a las funciones respectivas de las autoridades centrales y locales; a las funciones de las autoridades federales, estatales y provinciales; a las de las empresas propiedad del Estado y de los diversos tipos de organismos públicos autónomos o semiautónomos, o en lo que respecta a la naturaleza de la relación de empleo);

Teniendo en cuenta los problemas particulares que plantea la delimitación del campo de aplicación de un instrumento internacional y la adopción de definiciones a los fines del instrumento en razón de las diferencias existentes en muchos países entre el empleo público y el empleo privado, así como las dificultades de interpretación que se han planteado a propósito de la aplicación a los funcionarios públicos de las disposiciones pertinentes del Convenio sobre el derecho de sindicación y de negociación colectiva, 1949, y las observaciones por las cuales los órganos de control de la OIT han señalado en diversas ocasiones que ciertos gobiernos han aplicado dichas disposiciones en forma tal que grupos numerosos de empleados públicos han quedado excluidos del campo de aplicación del Convenio;

Después de haber decidido adoptar diversas proposiciones relativas a la libertad sindical y a los procedimientos para determinar las condiciones de empleo en el servicio público, cuestión que constituye el quinto punto del orden del día de la presente reunión, y

Después de haber decidido que dichas proposiciones revistan la forma de un convenio internacional, adopta, con fecha veintisiete de junio de mil novecientos setenta y ocho, el presente Convenio, que podrá ser citado como el Convenio sobre las relaciones de trabajo en la administración pública, 1978:

Parte I. Campo de Aplicación y Definiciones

Artículo 1

El presente Convenio deberá aplicarse a todas las personas empleadas por la administración pública, en la medida en que no les sean aplicables disposiciones más favorables de otros convenios internacionales del trabajo. 
La legislación nacional deberá determinar hasta qué punto las garantías previstas en el presente Convenio se aplican a los empleados de alto nivel que, por sus funciones, se considera normalmente que poseen poder decisorio o desempeñan cargos directivos o a los empleados cuyas obligaciones son de naturaleza altamente confidencial.

La legislación nacional deberá determinar asimismo hasta qué punto las garantías previstas en el presente Convenio son aplicables a las fuerzas armadas y a la policía.

Artículo 2

A los efectos del presente Convenio, la expresión empleado público designa a toda persona a quien se aplique el presente Convenio de conformidad con su artículo 1.

Artículo 3

A los efectos del presente Convenio, la expresión organización de empleados públicos designa a toda organización, cualquiera que sea su composición, que tenga por objeto fomentar y defender los intereses de los empleados públicos.

Parte II. Protección del Derecho de Sindicación

Artículo 4

Los empleados públicos gozarán de protección adecuada contra todo acto de discriminación antisindical en relación con su empleo.

2. Dicha protección se ejercerá especialmente contra todo acto que tenga por objeto:

a) sujetar el empleo del empleado público a la condición de que no se afilie a una organización de empleados públicos o a que deje de ser miembro de ella;

b) despedir a un empleado público, o perjudicarlo de cualquier otra forma, a causa de su afiliación a una organización de empleados públicos o de su participación en las actividades normales de tal organización.

Artículo 5

Las organizaciones de empleados públicos gozarán de completa independencia respecto de las autoridades públicas.

Las organizaciones de empleados públicos gozarán de adecuada protección contra todo acto de injerencia de una autoridad pública en su constitución, funcionamiento o administración.

Se consideran actos de injerencia a los efectos de este artículo principalmente los destinados a fomentar la constitución de organizaciones de empleados públicos dominadas por la autoridad pública, o a sostener económicamente, o en otra forma, organizaciones de empleados públicos con objeto de colocar estas organizaciones bajo el control de la autoridad pública.

Parte III. Facilidades que Deben Concederse a las Organizaciones de Empleados Públicos

Artículo 6

Deberán concederse a los representantes de las organizaciones reconocidas de empleados públicos facilidades apropiadas para permitirles el desempeño rápido y eficaz de sus funciones durante sus horas de trabajo o fuera de ellas.

La concesión de tales facilidades no deberá perjudicar el funcionamiento eficaz de la administración o servicio interesado.

3. La naturaleza y el alcance de estas facilidades se determinarán de acuerdo con los métodos mencionados en el artículo 7 del presente Convenio o por cualquier otro medio apropiado.

Parte IV. Procedimientos para la Determinación de las Condiciones de Empleo

Artículo 7

Deberán adoptarse, de ser necesario, medidas adecuadas a las condiciones nacionales para estimular y fomentar el pleno desarrollo y utilización de procedimientos de negociación entre las autoridades públicas competentes y las organizaciones de empleados públicos acerca de las condiciones de empleo, o de cualesquiera otros métodos que permitan a los representantes de los empleados públicos participar en la determinación de dichas condiciones.

Parte V. Solución de Conflictos 
Artículo 8

La solución de los conflictos que se planteen con motivo de la determinación de las condiciones de empleo se deberá tratar de lograr, de manera apropiada a las condiciones nacionales, por medio de la negociación entre las partes o mediante procedimientos independientes e imparciales, tales como la mediación, la conciliación y el arbitraje, establecidos de modo que inspiren la confianza de los interesados.

Parte VI. Derechos Civiles y Políticos

Artículo 9

Los empleados públicos, al igual que los demás trabajadores, gozarán de los derechos civiles y políticos esenciales para el ejercicio normal de la libertad sindical, a reserva solamente de las obligaciones que se deriven de su condición y de la naturaleza de sus funciones.

Parte VII. Disposiciones Finales

Artículo 10

Las ratificaciones formales del presente Convenio serán comunicadas, para su registro, al Director General de la Oficina Internacional del Trabajo.

Artículo 11

Este Convenio obligará únicamente a aquellos Miembros de la Organización Internacional del Trabajo cuyas ratificaciones haya registrado el Director General.

Entrará en vigor doce meses después de la fecha en que las ratificaciones de dos Miembros hayan sido registradas por el Director General.

Desde dicho momento, este Convenio entrará en vigor, para cada Miembro, doce meses después de la fecha en que haya sido registrada su ratificación.

Artículo 12

Todo Miembro que haya ratificado este Convenio podrá denunciarlo a la expiración de un período de diez años, a partir de la fecha en que se haya puesto inicialmente en vigor, mediante un acta comunicada, para su registro, al Director General de la Oficina Internacional del Trabajo. La denuncia no surtirá efecto hasta un año después de la fecha en que se haya registrado.

Todo Miembro que haya ratificado este Convenio y que, en el plazo de un año después de la expiración del período de diez años mencionado en el párrafo precedente, no haga uso del derecho de denuncia previsto en este artículo quedará obligado durante un nuevo período de diez años, y en lo sucesivo podrá denunciar este Convenio a la expiración de cada período de diez años, en las condiciones previstas en este artículo.

Artículo 13

El Director General de la Oficina Internacional del Trabajo notificará a todos los Miembros de la Organización Internacional del Trabajo el registro de cuantas ratificaciones, declaraciones y denuncias le comuniquen los Miembros de la Organización.

Al notificar a los Miembros de la Organización el registro de la segunda ratificación que le haya sido comunicada, el Director General llamará la atención de los Miembros de la Organización sobre la fecha en que entrará en vigor el presente Convenio.

Artículo 14

El Director General de la Oficina Internacional del Trabajo comunicará al Secretario General de las Naciones Unidas, a los efectos del registro y de conformidad con el artículo 102 de la Carta de las Naciones Unidas, una información completa sobre todas las ratificaciones, declaraciones y actas de denuncia que haya registrado de acuerdo con los artículos precedentes.

Artículo 15

Cada vez que lo estime necesario, el Consejo de Administración de la Oficina Internacional del Trabajo presentará a la Conferencia una memoria sobre la aplicación del Convenio, y considerará la conveniencia de incluir en el orden del día de la Conferencia la cuestión de su revisión total o parcial. 
Artículo 16

1. En caso de que la Conferencia adopte un nuevo convenio que implique una revisión total o parcial del presente, y a menos que el nuevo convenio contenga disposiciones en contrario:

a) la ratificación, por un Miembro, del nuevo convenio revisor implicará, ipso jure, la denuncia inmediata de este Convenio, no obstante las disposiciones contenidas en el artículo 12, siempre que el nuevo convenio revisor haya entrado en vigor;

b) a partir de la fecha en que entre en vigor el nuevo convenio revisor, el presente Convenio cesará de estar abierto a la ratificación por los Miembros.

Este Convenio continuará en vigor en todo caso, en su forma y contenido actuales, para los Miembros que lo hayan ratificado y no ratifiquen el convenio revisor.

Artículo 17

Las versiones inglesa y francesa del texto de este Convenio son igualmente auténticas.

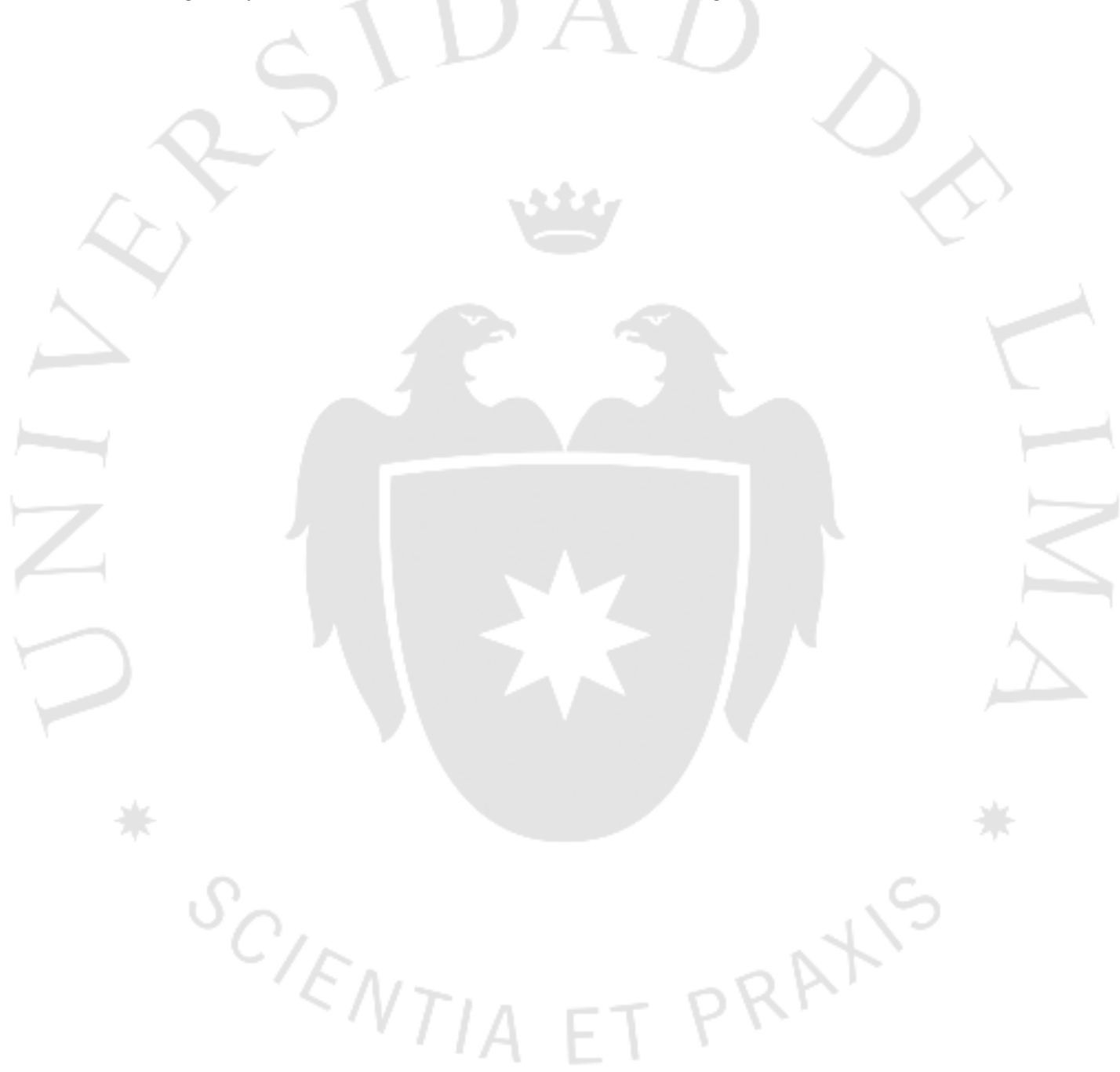




\section{Anexo $\mathbf{N}^{\circ}$ 4: Convenio $\mathbf{N}^{\circ} 154$ de la OIT: Convenio sobre el fomento de la negociación colectiva.}

Convenio sobre el fomento de la negociación colectiva (Entrada en vigor: 11 agosto 1983)Adopción: Ginebra, $67^{\mathrm{a}}$ reunión CIT (03 junio 1981) - Estatus: Instrumento actualizado (Convenios Técnicos).

\section{PARTE I. CAMPO DE APLICACIÓN Y DEFINICIONES}

Artículo 1

1. El presente Convenio se aplica a todas las ramas de actividad económica.

2. La legislación o la práctica nacionales podrán determinar hasta qué punto las garantías previstas en el presente Convenio son aplicables a las fuerzas armadas y a la policía.

3. En lo que se refiere a la administración pública, la legislación o la práctica nacionales podrán fijar modalidades particulares de aplicación de este Convenio.

Artículo 2

A los efectos del presente Convenio, la expresión negociación colectiva comprende todas las negociaciones que tienen lugar entre un empleador, un grupo de empleadores o una organización o varias organizaciones de empleadores, por una parte, y una organización o varias organizaciones de trabajadores, por otra, con el fin de: a) dfijar las condiciones de trabajo y empleo, o b) regular las relaciones entre empleadores y trabajadores, o c) regular las relaciones entre empleadores o sus organizaciones y una organización o varias organizaciones de trabajadores, o lograr todos estos fines a la vez.

Artículo 3

1. Cuando la ley o la práctica nacionales reconozcan la existencia de representantes de trabajadores que respondan a la definición del apartado b) del artículo 3) del Convenio sobre los representantes de los trabajadores, 1971, la ley o la práctica nacionales podrán determinar hasta qué punto la expresión negociación colectiva se extiende igualmente, a los fines del presente Convenio, a las negociaciones con dichos representantes.

2. Cuando en virtud del párrafo 1 de este artículo la expresión negociación colectiva incluya igualmente las negociaciones con los representantes de los trabajadores a que se refiere dicho párrafo, deberán adoptarse, si fuese necesario, medidas apropiadas para garantizar que la existencia de estos representantes no se utilice en menoscabo de la posición de las organizaciones de trabajadores interesadas. 


\section{PARTE II. MÉTODOS DE APLICACIÓN}

Artículo 4 En la medida en que no se apliquen por medio de contratos colectivos, por laudos arbitrales o por cualquier otro medio conforme a la práctica nacional, las disposiciones del presente Convenio deberán ser aplicadas por medio de la legislación nacional.

\section{PARTE III. FOMENTO DE LA NEGOCIACIÓN COLECTIVA}

\section{Artículo 5}

1. Se deberán adoptar medidas adecuadas a las condiciones nacionales para fomentar la negociación colectiva.

2. Las medidas a que se refiere el párrafo 1 de este artículo deberán tener por objeto que: a) la negociación colectiva sea posibilitada a todos los empleadores y a todas las categorías de trabajadores de las ramas de actividad a que se aplique el presente Convenio; b) la negociación colectiva sea progresivamente extendida a todas las materias a que se refieren los apartados a), b) y c) del artículo 2 del presente Convenio; c) sea fomentado el establecimiento de reglas de procedimiento convenidas entre las organizaciones de los empleadores y las organizaciones de los trabajadores; d) la negociación colectiva no resulte obstaculizada por la inexistencia de reglas que rijan su desarrollo o la insuficiencia o el carácter impropio de tales reglas; e) los órganos y procedimientos de solución de los conflictos laborales estén concebidos de tal manera que contribuyan a fomentar la negociación colectiva.

Artículo 6 Las disposiciones del presente Convenio no obstaculizarán el funcionamiento de sistemas de relaciones de trabajo en los que la negociación colectiva tenga lugar en el marco de mecanismos o de instituciones de conciliación o de arbitraje, o de ambos a la vez, en los que participen voluntariamente las partes en la negociación colectiva.

Artículo 7 Las medidas adoptadas por las autoridades públicas para estimular y fomentar el desarrollo de la negociación colectiva deberán ser objeto de consultas previas y, cuando sea posible, de acuerdos entre las autoridades públicas y las organizaciones de empleadores y de trabajadores.

Artículo 8 Las medidas previstas con objeto de fomentar la negociación colectiva no deberán ser concebidas o aplicadas de modo que obstaculicen la libertad de negociación colectiva. 


\section{ANEXO No 5: Ley 30057, Ley del Servicio Civil}

\section{TÍTULO PRELIMINAR}

Artículo I. Objeto de la Ley

El objeto de la presente Ley es establecer un régimen único y exclusivo para las personas que prestan servicios en las entidades públicas del Estado, así como para aquellas personas que están encargadas de su gestión, del ejercicio de sus potestades y de la prestación de servicios a cargo de estas.

Artículo II. Finalidad de la Ley

La finalidad de la presente Ley es que las entidades públicas del Estado alcancen mayores niveles de eficacia y eficiencia, y presten efectivamente servicios de calidad a través de un mejor Servicio Civil, así como promover el desarrollo de las personas que lo integran.

Artículo III. Principios de la Ley del Servicio Civil

Son principios de la Ley del Servicio Civil:

a) Interés general. El régimen del Servicio Civil se fundamenta en la necesidad de recursos humanos para una adecuada prestación de servicios públicos.

b) Eficacia y eficiencia. El Servicio Civil y su régimen buscan el logro de los objetivos del Estado y la realización de prestaciones de servicios públicos requeridos por el Estado y la optimización de los recursos destinados a este fin.

c) Igualdad de oportunidades. Las reglas del Servicio Civil son generales, impersonales, objetivas, públicas y previamente determinadas, sin discriminación alguna por razones de origen, raza, sexo, idioma, religión, opinión, condición económica o de cualquier otra índole.

CONCORDANCIAS: D.S. N 040-2014-PCM, (Reglamento General) Art. 224, inc. b)

d) Mérito. El régimen del Servicio Civil, incluyendo el acceso, la permanencia, progresión, mejora en las compensaciones y movilidad, se basa en la aptitud, actitud, desempeño, capacidad y evaluación permanente para el puesto de los postulantes y servidores civiles.

e) Provisión presupuestaria. Todo acto relativo al sistema del Servicio Civil está supeditado a la disponibilidad presupuestal, el cumplimiento de las reglas fiscales, la sostenibilidad de las finanzas del Estado, así como a estar previamente autorizado y presupuestado.

f) Legalidad y especialidad normativa. El régimen del Servicio Civil se rige únicamente por lo establecido en la Constitución Política, la presente Ley y sus normas reglamentarias.

g) Transparencia. La información relativa a la gestión del régimen del Servicio Civil es confiable, accesible y oportuna.

h) Rendición de cuentas de la gestión. Los servidores públicos encargados de la gestión de las entidades públicas rinden cuentas de la gestión que ejecutan.

i) Probidad y ética pública. El Servicio Civil promueve una actuación transparente, ética y objetiva de los servidores civiles. Los servidores actúan de acuerdo con los principios y valores éticos establecidos en la Constitución y las leyes que requieran la función pública. 
administrados.

j) Flexibilidad. El Servicio Civil procura adaptarse a las necesidades del Estado y de los

k) Protección contra el término arbitrario del Servicio Civil. La presente Ley otorga al servidor civil adecuada protección contra el término arbitrario del Servicio Civil.

\section{TÍTULO I: DISPOSICIONES GENERALES}

Artículo 1. Ámbito de aplicación

El régimen del Servicio Civil se aplica a las entidades públicas de:

a) El Poder Ejecutivo, incluyendo Ministerios y Organismos Públicos.

b) El Poder Legislativo.

c) El Poder Judicial.

d) Los Gobiernos Regionales.

e) Los Gobiernos Locales.

f) Los Organismos a los que la Constitución Política del Perú y las leyes confieren autonomía.

g) Las demás entidades y organismos, proyectos y programas del Estado, cuyas actividades se realizan en virtud de potestades administrativas y, por tanto, se consideran sujetas a las normas comunes de derecho público.

Artículo 2. Clasificación de los servidores civiles

Los servidores civiles de las entidades públicas se clasifican en los siguientes grupos:

a) Funcionario público.

b) Directivo público.

c) Servidor Civil de Carrera.

d) Servidor de actividades complementarias.

En cualquiera de estos grupos pueden existir servidores de confianza.

CONCORDANCIAS: D. LEG. N 1161, Tercera Disp. Comp. Final.

Artículo 3. Definiciones

a) Funcionario público. Es un representante político o cargo público representativo, que ejerce funciones de gobierno en la organización del Estado. Dirige o interviene en la conducción de la entidad, así como aprueba políticas y normas.

b) Directivo público. Es el servidor civil que desarrolla funciones relativas a la organización, dirección o toma de decisiones de un órgano, unidad orgánica, programa o proyecto especial. (*) RECTIFICADO POR FE DE ERRATAS

c) Servidor civil de carrera. Es el servidor civil que realiza funciones directamente vinculadas al cumplimiento de las funciones sustantivas y de administración interna de una entidad. 
d) Servidor de actividades complementarias. Es el servidor civil que realiza funciones indirectamente vinculadas al cumplimiento de las funciones sustantivas y de administración interna de una entidad.

e) Servidor de confianza. Es un servidor civil que forma parte del entorno directo e inmediato de los funcionarios públicos o directivos públicos y cuya permanencia en el Servicio Civil está determinada y supeditada a la confianza por parte de la persona que lo designó. Puede formar parte del grupo de directivos públicos, servidor civil de carrera, o servidor de actividades complementarias. Ingresa sin concurso público de méritos, sobre la base del poder discrecional con que cuenta el funcionario que lo designa. No conforma un grupo y se sujeta a las reglas que correspondan al puesto que ocupa.

f) Puesto. Es el conjunto de funciones y responsabilidades que corresponden a una posición dentro de una entidad, así como los requisitos para su adecuado ejercicio. Se encuentra descrito en los instrumentos de gestión de la entidad.

g) Familia de puestos. Es el conjunto de puestos con funciones, características y propósitos similares. Cada familia de puestos se organiza en niveles de menor a mayor complejidad de funciones y responsabilidades.

h) Banda remunerativa. Es el rango de montos máximos y mínimos definidos por el resultado de la valorización de puestos de cada nivel de una familia de puestos.

i) Distribución de la valorización. Es el mecanismo por el cual se calcula la compensación económica del puesto que finalmente determina el ingreso económico del servidor civil.

\section{TÍTULO II: ORGANIZACIÓN DEL SERVICIO CIVIL}

Artículo 4. Sistema administrativo de gestión de recursos humanos

El sistema administrativo de gestión de recursos humanos establece, desarrolla y ejecuta la política de Estado respecto del Servicio Civil, a través del conjunto de normas, principios, recursos, métodos, procedimientos y técnicas utilizados por las entidades públicas en la gestión de los recursos humanos.

El sistema está integrado por:

a) La Autoridad Nacional del Servicio Civil (Servir).

b) Las oficinas de recursos humanos de las entidades o las que hagan sus veces.

c) El Tribunal del Servicio Civil.

Artículo 5. Autoridad Nacional del Servicio Civil (Servir)

La Autoridad Nacional del Servicio Civil, en adelante Servir, formula la política nacional del Servicio Civil, ejerce la rectoría del sistema y resuelve las controversias de conformidad con lo establecido en el Decreto Legislativo 1023 y sus normas modificatorias, garantizando desde su elección como órgano técnico su autonomía, profesionalismo e imparcialidad.

Artículo 6. Oficina de Recursos Humanos

Las oficinas de recursos humanos de las entidades públicas, o las que hagan sus veces, constituyen el nivel descentralizado responsable de la gestión de recursos humanos, sujetándose a las disposiciones que emita el ente rector.

En cada entidad pública la oficina de recursos humanos, o la que haga sus veces, tiene las siguientes funciones: 
a) Ejecutar e implementar las disposiciones, lineamientos, instrumentos o herramientas de gestión establecidas por Servir y por la entidad.

b) Formular lineamientos y políticas para el desarrollo del plan de gestión de personas y el óptimo funcionamiento del sistema de gestión de recursos humanos, incluyendo la aplicación de indicadores de gestión.

c) Supervisar, desarrollar y aplicar iniciativas de mejora continua en los procesos que conforman el sistema de gestión de recursos humanos.

d) Realizar el estudio y análisis cualitativo y cuantitativo de la provisión de personal al servicio de la entidad de acuerdo a las necesidades institucionales.

e) Gestionar los perfiles de puestos.

f) Administrar y mantener actualizado en el ámbito de su competencia el Registro Nacional de Personal del Servicio Civil y el Registro Nacional de Sanciones de Destitución y Despido que lo integra.

g) Otras funciones que se establezcan en las normas reglamentarias y lo dispuesto por el ente rector del sistema.

Artículo 7. El Tribunal del Servicio Civil

El Tribunal del Servicio Civil, en adelante el Tribunal, es un órgano integrante de Servir que tiene por función la resolución de las controversias individuales que se susciten al interior del sistema de conformidad con lo establecido en el Decreto Legislativo 1023, Decreto Legislativo que crea la Autoridad Nacional del Servicio Civil, rectora del Sistema Administrativo de Gestión de Recursos Humanos, y disposiciones modificatorias.

\section{TÍTULO III: DEL RÉGIMEN DEL SERVICIO CIVIL CAPÍTULO I: INCORPORACIÓN AL SERVICIO CIVIL}

Artículo 8. Proceso de selección

El proceso de selección es el mecanismo de incorporación al grupo de directivos públicos, servidores civiles de carrera y servidores de actividades complementarias. Tiene por finalidad seleccionar a las personas más idóneas para el puesto sobre la base del mérito, competencia y transparencia, garantizando la igualdad en el acceso a la función pública.

En el caso de los servidores de confianza, el proceso de selección se limita al cumplimiento del perfil establecido para el puesto y no requieren aprobar un concurso público de méritos.

Artículo 9. Requisitos para acceder al Servicio Civil

Para participar en un proceso de incorporación al Servicio Civil se requiere:

a) Estar en ejercicio pleno de sus derechos civiles.

b) Cumplir con los requisitos mínimos exigidos para el puesto.

c) No tener condena por delito doloso.

d) No estar inhabilitado administrativa o judicialmente para el ejercicio de la profesión, para contratar con el Estado o para desempeñar función pública. 
e) Tener la nacionalidad peruana, en los casos en que la naturaleza del puesto lo exija, conforme a la Constitución Política del Perú y a las leyes específicas.

f) Los demás requisitos previstos en la Constitución Política del Perú y las leyes.

\section{CAPÍTULO II: DE LA GESTIÓN DE LA CAPACITACIÓN}

Artículo 10. Finalidad del proceso de capacitación

La finalidad del proceso de capacitación es buscar la mejora del desempeño de los servidores civiles para brindar servicios de calidad a los ciudadanos. Asimismo, busca fortalecer y mejorar las capacidades de los servidores civiles para el buen desempeño y es una estrategia fundamental para alcanzar el logro de los objetivos institucionales.

Artículo 11. Reglas de la gestión de la capacitación

La gestión de la capacitación se rige por las siguientes reglas:

a) Los recursos destinados a capacitación están orientados a mejorar la productividad de las entidades públicas. La planificación de la capacitación se realiza a partir de las necesidades de cada institución y de la administración pública en su conjunto.

b) El acceso a la capacitación en el sector público se basa en criterios objetivos que garanticen la productividad de los recursos asignados, la imparcialidad y la equidad.

c) La gestión de la capacitación en el sector público procura la especialización y eficiencia, fomentando el desarrollo de un mercado de formación para el sector público, competitivo y de calidad, a partir de la capacidad instalada de las universidades, de la Escuela Nacional de Administración Pública, de los institutos y de otros centros de formación profesional y técnica, de reconocido prestigio.

d) Los resultados de la capacitación que reciben los servidores civiles y su aprovechamiento en favor de la institución deben ser medibles.

e) El servidor civil que recibe una capacitación financiada por el Estado está obligado a permanecer, al menos, el doble de tiempo que duró la capacitación. Dicha obligación no alcanza a funcionarios públicos ni servidores de confianza. No obstante, si estos últimos renuncian al término de la capacitación, deben devolver el valor de la misma.

Artículo 12. Ente rector de la capacitación para el sector público

Corresponde a Servir planificar, priorizar, desarrollar, así como gestionar y evaluar la política de capacitación para el sector público.

Artículo 13. Planificación de necesidades de capacitación

Las entidades públicas deben planificar su capacitación tomando en cuenta la demanda en aquellos temas que contribuyan efectivamente al cierre de brechas de conocimiento o competencias de los servidores para el mejor cumplimiento de sus funciones, o que contribuyan al cumplimiento de determinado objetivo institucional.

Artículo 14. Actividades y servidores excluidos de la capacitación

No son consideradas como actividades de capacitación, los estudios primarios y secundarios ni los estudios de pregrado que conlleven a la obtención de un título profesional.

No están comprendidos dentro de los programas de capacitación, con excepción de aquellos destinados a la inducción, los servidores públicos contratados temporalmente a los cuales se refiere el artículo 84 de la presente Ley. 
Artículo 15. De la certificación

Servir certifica los programas de capacitación laboral y profesional ofrecidos en universidades, institutos y otros centros de formación profesional y técnica, preferentemente sobre los temas de Gestión Pública, Políticas Públicas, Desarrollo y Gestión de Proyectos para los tres niveles de gobierno. La certificación es voluntaria y se efectúa de conformidad con las normas que para dichos efectos emite Servir.

Artículo 16. Tipos de capacitación

Los tipos de capacitación son:

a) Formación Laboral. Tiene por objeto capacitar a los servidores civiles en cursos, talleres, seminarios, diplomados $\mathrm{u}$ otros que no conduzcan a grado académico o título profesional y que permitan, en el corto plazo, mejorar la calidad de su trabajo y de los servicios que prestan a la ciudadanía. Se aplica para el cierre de brechas de conocimientos o competencias, así como para la mejora continua del servidor civil, respecto de sus funciones concretas y de las necesidades institucionales.

Están comprendidas en la formación laboral la capacitación interinstitucional y las pasantías, organizadas con la finalidad de transmitir conocimientos de utilidad general a todo el sector público.

b) Formación Profesional. Conlleva a la obtención, principalmente, del grado académico de maestrías en áreas requeridas por las entidades. Está destinada a preparar a los servidores públicos en universidades, institutos y otros centros de formación profesional y técnica, de primer nivel; atendiendo a la naturaleza de las funciones que desempeñan y a su formación profesional.

Artículo 17. Reglas especiales para la formación laboral

El personal del Servicio Civil puede acceder a la formación laboral con cargo a los recursos de la entidad. Los recursos asignados para la formación laboral, en el caso de los funcionarios públicos y servidores civiles de confianza, no puede exceder, por año, del doble del total de su compensación económica mensualizada.

Las oficinas de recursos humanos o las que hagan sus veces gestionan dicha capacitación, conforme a la presente Ley y sus disposiciones reglamentarias y complementarias.

Artículo 18. Reglas especiales para la formación profesional

Solo los servidores civiles de carrera pueden ser sujetos de formación profesional. Excepcionalmente, los directivos públicos que no sean de confianza pueden acceder a maestrías, siempre que ellas provengan de un fondo sectorial, de un ente rector o de algún fideicomiso del Estado para becas y créditos.

Aquellos servidores civiles que reciban formación profesional con cargo a recursos del Estado peruano tienen la obligación de devolver el costo de la misma en caso de que obtengan notas desaprobatorias o menores a las exigidas por la entidad pública antes del inicio de la capacitación.

\section{CAPÍTULO III: DE LA GESTIÓN DEL RENDIMIENTO Y LA EVALUACIÓN DE DESEMPEÑO}

Artículo 19. Finalidad del proceso de evaluación

La gestión del rendimiento comprende el proceso de evaluación de desempeño y tiene por finalidad estimular el buen rendimiento y el compromiso del servidor civil. Identifica y reconoce el aporte de los servidores con las metas institucionales y evidencia las necesidades requeridas por los servidores para mejorar el desempeño en sus puestos y de la entidad. 
Artículo 20. Alcance de la evaluación de desempeño

Están sujetos a evaluación de desempeño los directivos públicos, los servidores civiles de carrera y los servidores de actividades complementarias.

Artículo 21. Responsables del proceso de evaluación

Las oficinas de recursos humanos, o las que hagan sus veces, y la alta dirección son responsables de que las evaluaciones se realicen en la oportunidad y en las formas establecidas por Servir.

El 30 de agosto de cada año Servir envía a la Comisión de Presupuesto y Cuenta General de la República del Congreso de la República y a la Contraloría General de la República un informe sobre los resultados obtenidos en las evaluaciones de desempeño realizadas en el Estado.

Artículo 22. Proceso de evaluación de desempeño

La evaluación de desempeño es el proceso obligatorio, integral, sistemático y continuo de apreciación objetiva y demostrable del rendimiento del servidor público en cumplimiento de los objetivos y funciones de su puesto. Es llevada a cabo obligatoriamente por las entidades públicas en la oportunidad, forma y condiciones que señale el ente rector.

Todo proceso de evaluación se sujeta a las siguientes reglas mínimas:

a) Los factores a medir como desempeño deben estar relacionados con las funciones del puesto.

b) Se realiza en función de factores o metas mensurables y verificables.

c) El servidor debe conocer por anticipado los procedimientos, factores o metas con los que es evaluado antes de la evaluación.

d) Se realiza con una periodicidad anual.

e) El servidor que no participe en un proceso de evaluación por motivos atribuibles a su exclusiva responsabilidad es calificado como personal desaprobado.

Artículo 23.Tipos de evaluación de desempeño

La evaluación de desempeño debe ajustarse a las características institucionales, a los servicios que brindan y a los tipos de puesto existentes en una entidad. Servir establece criterios objetivos para definir el tipo de evaluación de desempeño que corresponde en cada caso.

Artículo 24. Los factores de evaluación

La evaluación se realiza tomando en cuenta, principalmente, factores o metas individuales relacionadas a la función que desempeña el servidor. Adicionalmente, se pueden tomar en cuenta factores grupales cuando se hubiera establecido oficialmente indicadores de gestión para la entidad y sus unidades orgánicas.

Artículo 25. Retroalimentación y calificación

El proceso de evaluación debe garantizar que se comunique al servidor civil los métodos, la oportunidad, las condiciones de la evaluación y los resultados de la misma, de manera que se puedan plantear los compromisos de mejora y realizar el seguimiento correspondiente.

La calificación debe ser notificada al servidor evaluado. El servidor puede solicitar documentadamente la confirmación de la calificación adjudicada ante un Comité cuya 
conformación la establece el reglamento, que define la situación de modo irrecurrible; salvo la calificación como personal "desaprobado" que lleva a la terminación del vínculo en aplicación del literal i) del artículo 49 de la presente Ley, en cuyo caso procede recurrir al Tribunal del Servicio Civil en vía de apelación.

Artículo 26. Consecuencias de la evaluación

La evaluación es la base para la progresión en el grupo de servidores civiles de carrera, las compensaciones y la determinación de la permanencia en el Servicio Civil.

Por la evaluación, se califica a los servidores como:

a) Personal de rendimiento distinguido;

b) Personal de buen rendimiento;

c) Personal de rendimiento sujeto a observación; y,

d) Personal desaprobado.

Solo los servidores que califiquen como personal de rendimiento distinguido o personal de buen rendimiento tienen derecho a participar en los procesos de progresión en la carrera que se convoquen en el Estado.

Las entidades solo pueden calificar como personal de rendimiento distinguido hasta el diez por ciento (10\%) de los servidores civiles en cada evaluación. En caso de empate, se pueden plantear mecanismos que permitan cumplir con lo señalado en el presente artículo.

Por resolución de Servir se establecen los métodos y criterios de evaluación, debiéndose tomar en cuenta el número total de servidores de la entidad, el tipo de puestos existentes, el nivel de gobierno, el sector al que pertenece, la naturaleza de las funciones que cumple, la naturaleza de sus servicios o el rango de recursos presupuestarios.

Las oficinas de recursos humanos, o las que hagan sus veces, desarrollan actividades de capacitación para atender los casos de personal evaluado en la categoría de personal de rendimiento sujeto a observación, que garantice un proceso adecuado de formación laboral, en los seis (6) meses posteriores a la evaluación.

Si habiendo recibido formación laboral el servidor fuera evaluado por segunda vez como personal de rendimiento sujeto a observación, es calificado como personal "desaprobado".

Artículo 27. Supervisión de los procesos de evaluación

Corresponde a Servir aprobar los lineamientos y las metodologías para el desarrollo de los procesos de evaluación, así como supervisar su cumplimiento por parte de las entidades públicas, pudiendo hacer cumplir los mismos en los casos en los que detecte discrepancias que desnaturalicen los objetivos de la evaluación.

\section{CAPÍTULO IV: DE LAS COMPENSACIONES}

Artículo 28. Compensación

La compensación es el conjunto de ingresos y beneficios que la entidad destina al servidor civil para retribuir la prestación de sus servicios a la entidad de acuerdo al puesto que ocupa.

El objetivo de la compensación es captar, mantener y desarrollar un cuerpo de servidores efectivo que contribuya con el cumplimiento de los objetivos institucionales.

Artículo 29. Estructura de las compensaciones 
La compensación se estructura de la siguiente manera:

a) La compensación económica del puesto es la contraprestación en dinero, correspondiente a las actividades realizadas en un determinado puesto.

b) La compensación no económica está constituida por los beneficios otorgados para motivar y elevar la competitividad de los servidores civiles. Estos beneficios no son de libre disposición del servidor.

Artículo 30. Reglas generales de la compensación

La gestión de la compensación se realiza a través del conjunto de principios, normas y medidas institucionales que regulan la retribución por la prestación de servicios personales al Estado.

La gestión de la compensación se basa en los siguientes principios:

a) Competitividad: El sistema de compensaciones busca atraer y retener personal idóneo en el Servicio Civil peruano.

b) Equidad: Al trabajo desempeñado en puestos similares pero en condiciones diferentes de exigencia, responsabilidad o complejidad le corresponde diferente compensación económica y al trabajo desempeñado en puestos y condiciones similares le corresponde similar compensación económica.

c) Consistencia interna: Las compensaciones dentro de la misma entidad guardan relación con las condiciones de exigencia, responsabilidad y complejidad del puesto.

d) Consistencia intergubernamental: Las compensaciones de puestos similares, entre las entidades de la administración pública son comparables entre sí. Esta regla se aplica teniendo en cuenta el nivel de responsabilidad y competencias de la entidad.

La nomenclatura de los puestos no conlleva a la presunción de igual trabajo y por ende no implica similar compensación, ni sirve de base para evaluar la consistencia interna ni intergubernamental.

\section{Artículo 31. Compensación económica}

31.1 La compensación económica que se otorga a los servidores civiles de las entidades públicas es anual y está compuesta de la valorización que solo comprende:

a) Principal. Componente económico directo de la familia de puestos.

b) Ajustada. Otorgada al puesto en razón de la entidad y en función a criterios de jerarquía, responsabilidad, presupuesto a cargo, personal directamente a su cargo, alcance de sus decisiones o monto que involucran las decisiones sobre recursos del Estado.

c) Vacaciones. Entrega económica por el derecho vacacional.

d) Aguinaldos. Entregas económicas por Fiestas Patrias y Navidad.

Adicionalmente y de acuerdo a situaciones atípicas para el desempeño de un puesto, debido a condiciones de accesibilidad geográfica, por altitud, riesgo de vida, riesgo legal o servicios efectivos en el extranjero, se puede incorporar la Valorización Priorizada, la cual es aprobada mediante decreto supremo refrendado por el Ministro de Economía y Finanzas. Esta modalidad de compensación se restringe al tiempo que dure las condiciones de su asignación. 
31.2 La compensación económica se paga mensualmente e incluye la Valorización Principal y la Ajustada, y la Priorizada, de corresponder. El pago mensual corresponde a un catorceavo (1/14) de la compensación económica. Las vacaciones y los aguinaldos son equivalentes al pago mensual. Esta disposición no admite excepciones ni interpretaciones, ni es materia de negociación. $(*)$

(*) Extremo declarado inconstitucional por el Literal b) del Resolutivo 1 del Pleno Jurisdiccional del Tribunal Constitucional Expedientes 0025-2013-PI-TC; 0003-2014-PI-TC; 0008-2014-PI-TC; 0017-2014-PI-TC, emitido el 26 de abril de 2016, quedando redactado el presente numeral conforme al siguiente texto:

"La compensación económica se paga mensualmente e incluye la Valorización Principal y la Ajustada, y la Priorizada, de corresponder. El pago mensual corresponde a un catorceavo (1/14) de la compensación económica. Las vacaciones y los aguinaldos son equivalentes al pago mensual. Esta disposición no admite excepciones ni interpretaciones".

31.3 Las bandas remunerativas de puestos consideran únicamente los conceptos recogidos en los literales a) y b) del numeral 31.1 precedente.

31.4 La distribución de la valorización Principal por familia y la Ajustada se aprueba mediante decreto supremo refrendado por el Ministro de Economía y Finanzas, en coordinación con Servir.

31.5 Solo los literales a), b), c) y d) del numeral 31.1 están sujetos a cargas sociales: Seguridad Social en salud y pensiones, así como al Impuesto a la Renta.

CONCORDANCIAS: D.S. $\mathrm{N}^{\circ}$ 138-2014-EF (Reglamento de Compensaciones), Segunda Disp. Comp. Final (Aportes, contribuciones e impuestos)

Artículo 32. Fuente de financiamiento de la compensación económica del puesto

La compensación económica del puesto se financia con recursos ordinarios, recursos directamente recaudados o ambos, de acuerdo a las partidas presupuestales correspondientes programadas para cada entidad. En ningún caso se puede utilizar financiamiento proveniente de partidas presupuestales diferentes a las programadas.

El pago de dicha compensación solo corresponde como contraprestación por el trabajo efectivamente realizado, quedando prohibido el pago de compensaciones por días no laborados, salvo el pago por aplicación de suspensión imperfecta a que se refiere el numeral 47.2 del artículo 47 de la presente Ley. Asimismo, queda prohibido autorizar o efectuar adelantos con cargo a la compensación económica del puesto.

Artículo 33. Compensación por tiempo de servicios

El cálculo de la compensación por tiempo de servicios (CTS) equivale al 100\% del promedio mensual del monto resultante de la(*)NOTA SPIJ valorizaciones Principal y Ajustada que les fueron pagadas al servidor civil en cada mes durante los últimos treinta y seis (36) meses de trabajo efectivamente prestado, por cada año de servicios efectivamente prestados. En caso de que la antigüedad de trabajo efectivamente prestado sea menor a treinta y seis (36) meses, se hace el cálculo de manera proporcional.

El pago de la CTS es cancelatorio y solo se efectiviza a la culminación del vínculo del servidor con cada entidad.

Artículo 34. Reglas para el pago de la compensación económica del puesto 
En el tratamiento para el pago de las compensaciones económicas se tiene en cuenta las siguientes reglas:

a) La planilla única de pago de las entidades solo es afectada por los descuentos establecidos por ley, por cuotas sindicales expresamente autorizadas por el servidor, y por mandato judicial expreso, de corresponder.

b) Las compensaciones económicas no están sujetas a indexaciones, homologaciones, nivelaciones o cualquier otro mecanismo similar de vinculación.

c) Las compensaciones económicas se establecen en moneda nacional salvo los casos de servicios efectivos en el extranjero.

d) Los funcionarios públicos y directivos públicos que no presten servicios a tiempo completo solo reciben la proporción equivalente a la compensación económica del puesto.

e) La compensación económica se abona a cada servidor civil luego de ser registrada y autorizada por el "Aplicativo informático para el registro centralizado de planillas y de datos de los recursos humanos del Sector Público - Aplicativo Informático" a cargo del Ministerio de Economía y Finanzas.

f) La compensación económica por los trabajos efectivamente realizados por el servidor civil solo puede ser determinada según se regula en la presente Ley.

Las reglas citadas en el presente artículo son de aplicación general inclusive para las carreras especiales.

\section{CAPÍTULO V: DERECHOS Y OBLIGACIONES DEL PERSONAL DEL SERVICIO CIVIL}

Artículo 35. Derechos individuales del servidor civil

El servidor civil tiene los siguientes derechos:

a) Percibir una compensación de acuerdo a lo establecido en la presente Ley y sus normas reglamentarias. Los derechos y beneficios correspondientes a un puesto no son transferibles de producirse un supuesto de movilidad a otro puesto.

b) Gozar de descanso vacacional efectivo y continuo de treinta (30) días por cada año completo de servicios, incluyendo los días de libre disponibilidad, regulados en el reglamento. Mediante decreto supremo el Poder Ejecutivo puede establecer que hasta quince (15) días de dicho período se ejecuten de forma general. El no goce del beneficio en el año siguiente en que se genera el derecho no genera compensación monetaria alguna y el descanso se acumula. máximo.

c) Jornada de ocho (8) horas diarias o cuarenta y ocho (48) horas semanales, como

d) Descanso semanal obligatorio de veinticuatro (24) horas consecutivas, como mínimo.

e) Un tiempo de refrigerio, que no forma parte de la jornada de trabajo. derechos.

f) Impugnar ante las instancias correspondientes las decisiones que afecten sus

g) Permisos y licencias de acuerdo a lo establecido en las normas reglamentarias.

h) Seguridad social en salud y pensiones, de acuerdo a la legislación sobre la materia. 
i) Gozar de los derechos a que hace referencia la Ley 29783, Ley de Seguridad y Salud en el Trabajo.

j) Seguro de vida y de salud en los casos y con las condiciones y límites establecidos por las normas reglamentarias.

k) Ejercer la docencia o participar en órganos colegiados percibiendo dietas, sin afectar el cumplimiento de sus funciones o las obligaciones derivadas del puesto.

1) Contar con la defensa y asesoría legal, asesoría contable, económica o afín, con cargo a los recursos de la entidad para su defensa en procesos judiciales, administrativos, constitucionales, arbitrales, investigaciones congresales y policiales, ya sea por omisiones, actos o decisiones adoptadas o ejecutadas en el ejercicio de sus funciones, inclusive como consecuencia de encargos, aun cuando al momento de iniciarse el proceso hubiese concluido la vinculación con la entidad. Si al finalizar el proceso se demostrara responsabilidad, el beneficiario debe reembolsar el costo del asesoramiento y de la defensa especializados.

m) No son de aplicación al servidor civil las normas que establezcan derechos en favor de personal sujeto a otro régimen o carrera.

n) Otros establecidos por ley.

CONCORDANCIAS: D.S. N 040-2014-PCM (Reglamento General), Art. 138 (Derechos Individuales del servidor civil)

Artículo 36. Efectos de la destitución nula o injustificada

La destitución declarada nula o injustificada por el Tribunal del Servicio Civil o el juez otorga al servidor civil el derecho a solicitar el pago de una indemnización o la reposición. En caso de que la entidad se haya extinguido o esté en proceso de hacerlo sólo corresponde la indemnización. Aquel servidor civil repuesto lo es en su puesto u otro del mismo nivel. Todo servidor civil repuesto se sujeta a los mismos deberes, derechos y condiciones aplicables a los servidores del grupo que corresponda al momento de la reposición.

Es nula la destitución que se fundamente en discriminación por razón de origen, raza, sexo, idioma, religión, opinión, condición económica o de cualquiera otra índole.

Las normas reglamentarias establecen la indemnización a que se refiere el presente artículo. No procede reposición ni indemnización en el caso de los servidores de confianza. Para el caso de funcionarios públicos y directivos públicos que no sean de confianza se aplican las reglas especiales previstas en la presente Ley.

Artículo 37. Plazo de prescripción

La prescripción de la acción de cobro de los ingresos, beneficios sociales y otros derechos derivados de la compensación económica de los servidores civiles tiene plazo de cuatro (4) años y su cómputo se inicia al término de la relación con la entidad en la que se generó el derecho que se invoque.

En los demás casos de prescripción se aplica lo dispuesto en las normas reglamentarias. En ninguno de estos casos la prescripción puede ser mayor a seis (6) meses contados desde la fecha en que ocurrió el acto que la motiva.

Artículo 38. Prohibición de doble percepción de ingresos

Los servidores del Servicio Civil no pueden percibir del Estado más de una compensación económica, remuneración, retribución, emolumento o cualquier tipo de ingreso. Es incompatible la percepción simultánea de dichos ingresos con la pensión por servicios 
prestados al Estado o por pensiones financiadas por el Estado, salvo excepción establecida por ley.

Las únicas excepciones las constituyen la percepción de ingresos por función docente efectiva y la percepción de dietas por participación en uno (1) de los directorios de entidades o empresas estatales o en Tribunales Administrativos o en otros órganos colegiados.

Queda prohibida la percepción de ingresos por dedicación de tiempo completo en más de una entidad pública a la vez.

CONCORDANCIAS: D.S. $\quad \mathrm{N}^{\circ}$ 040-2014-PCM (Reglamento General), Art. 158 (Incompatibilidad de doble percepción)

Artículo 39. Obligaciones de los servidores civiles

Son obligaciones de los servidores civiles, las siguientes: público.

a) Cumplir leal y diligentemente los deberes y funciones que impone el servicio

b) Privilegiar los intereses del Estado sobre los intereses propios o de particulares.

c) Informar oportunamente a los superiores jerárquicos de cualquier circunstancia que ponga en riesgo o afecte el logro de los objetivos institucionales o la actuación de la entidad.

d) Salvaguardar los intereses del Estado y emplear austeramente los recursos públicos. Los recursos y el personal a su cargo se asignan exclusivamente para el servicio oficial.

CONCORDANCIAS: D.S. $\quad \mathrm{N}^{\circ}$ 040-2014-PCM (Reglamento General), Art. 159 (Incompatibilidades por competencia funcional directa)

e) No emitir opiniones ni brindar declaraciones en nombre de la entidad, salvo autorización expresa del superior jerárquico competente o cuando ello corresponda por la naturaleza del puesto.

f) Informar a la autoridad superior o denunciar ante la autoridad correspondiente los actos delictivos, faltas disciplinarias o irregularidades que conozca.

g) Actuar con imparcialidad y neutralidad política.

CONCORDANCIAS: D.S. $\quad \mathrm{N}^{\circ}$ 040-2014-PCM (Reglamento General), Art. 159 (Incompatibilidades por competencia funcional directa)

h) No participar ni intervenir por sí o por terceras personas, directa o indirectamente, en los contratos con su entidad o cualquier otra entidad del Estado en los que tenga interés el propio servidor civil, su cónyuge o parientes hasta el cuarto grado de consanguinidad o segundo de afinidad.

CONCORDANCIAS: D.S. $\quad \mathrm{N}^{\circ}$ 040-2014-PCM (Reglamento General), Art. 159 (Incompatibilidades por competencia funcional directa)

i) No participar ni intervenir por sí o por terceras personas, directa o indirectamente, en la gestión de intereses en un procedimiento administrativo de su entidad. En el caso del nivel nacional de gobierno, esta prohibición se extiende a los procedimientos administrativos tramitados ante todas las entidades pertenecientes a su sector. 
CONCORDANCIAS: D.S. $\quad \mathrm{N}^{\circ}$ 040-2014-PCM (Reglamento General), Art. 159 (Incompatibilidades por competencia funcional directa)

j) Guardar secreto o reserva de la información calificada como tal por las normas sobre la materia, aun cuando ya no formen parte del Servicio Civil.

CONCORDANCIAS: D.S. $\mathrm{N}^{\circ}$ 040-2014-PCM (Reglamento General), Art. 156, lit. k) (Obligaciones del servidor)

k) Mejorar continuamente sus competencias y mantener la iniciativa en sus labores.

1) Someterse a las evaluaciones que se efectúen en el marco de la presente Ley.

m) Las demás que señale la presente Ley, sus normas reglamentarias y demás normas que regulan el Servicio Civil, en cuanto fueran aplicables.

CONCORDANCIAS: D.S. $\quad \mathrm{N}^{\circ}$ 040-2014-PCM (Reglamento General), Art. 157 (Prohibiciones)

\section{CAPÍTULO VI: DERECHOS COLECTIVOS}

Artículo 40. Derechos colectivos del servidor civil

Los derechos colectivos de los servidores civiles son los previstos en el Convenio 151 de la Organización Internacional del Trabajo (OIT) y en los artículos de la función pública establecidos en la Constitución Política del Perú. No están comprendidos los funcionarios públicos, directivos públicos ni los servidores de confianza.

Se aplica supletoriamente lo establecido en el Texto Único Ordenado de la Ley de Relaciones Colectivas de Trabajo, aprobado mediante Decreto Supremo 010-2003-TR, en lo que no se oponga a lo establecido en la presente Ley.

Ninguna negociación colectiva puede alterar la valorización de los puestos que resulten de la aplicación de la presente Ley.(*)

(*) Extremo declarado inconstitucional por el Literal e) del Resolutivo 1 del Pleno Jurisdiccional del Tribunal Constitucional Expedientes 0025-2013-PI-TC; 0003-2014-PI-TC; 0008-2014-PI-TC; 0017-2014-PI-TC, publicado el 04 mayo 2016, quedando redactado el presente artículo conforme al siguiente texto:

"Los derechos colectivos de los servidores civiles son los previstos en el Convenio 151 de la Organización Internacional del Trabajo (OIT) y en los artículos de la función pública establecidos en la Constitución Política del Perú. No están comprendidos los funcionarios públicos, directivos públicos ni los servidores de confianza

Se aplica supletoriamente lo establecido en el Texto Único Ordenado de la Ley de Relaciones Colectivas de Trabajo, aprobado mediante Decreto Supremo 010-2003-TR, en lo que no se oponga a lo establecido en la presente Ley".

Artículo 41. Normas específicas respecto a la sindicación

Los servidores civiles tienen derecho a organizarse con fines de defensa de sus intereses. Las organizaciones de servidores civiles deben coadyuvar en el propósito de mejora continua del servicio al ciudadano y de no afectar el funcionamiento eficiente de la entidad o la prestación del servicio.

La autoridad no debe promover actos que limiten la constitución de organismos sindicales o el ejercicio del derecho de sindicación. 
Artículo 42. Solicitudes de cambio de condiciones de trabajo o condiciones de empleo

Los servidores civiles tienen derecho a solicitar la mejora de sus compensaciones no económicas, incluyendo el cambio de condiciones de trabajo o condiciones de empleo, de acuerdo con las posibilidades presupuestarias y de infraestructura de la entidad y la naturaleza de las funciones que en ella se cumplen. (*)

(*) Artículo declarado inconstitucional por el Literal c) del Resolutivo 1 del Pleno Jurisdiccional del Tribunal Constitucional Expedientes 0025-2013-PI-TC; 0003-2014-PI-TC; 0008-2014-PI-TC; 0017-2014-PI-TC, publicado el 04 mayo 2016, quedando redactado de la siguiente manera:

"Los servidores civiles tienen derecho a solicitar la mejora de sus condiciones de trabajo o condiciones de empleo, de acuerdo con las posibilidades presupuestarias y de infraestructura de la entidad y la naturaleza de las funciones que en ella se cumplen".

Artículo 43. Inicio de la negociación colectiva

La negociación colectiva se inicia con la presentación de un pliego de reclamos que debe contener un proyecto de convención colectiva, con lo siguiente:

a) Nombre o denominación social y domicilio de la entidad pública a la cual se dirige.

b) Denominación y número de registro del o de los sindicatos que lo suscriben, y domicilio único que señalen para efectos de las notificaciones.

c) De no existir sindicato, las indicaciones que permitan identificar a la coalición de trabajadores que lo presenta.

d) La nómina de los integrantes de la comisión negociadora no puede ser mayor a un servidor civil por cada cincuenta (50) servidores civiles de la entidad que suscriben el registro del sindicato hasta un máximo de seis (6) servidores civiles.

e) Las peticiones que se formulan respecto a condiciones de trabajo o de empleo que se planteen deben tener forma de cláusula e integrarse armónicamente dentro de un solo proyecto de convención. Se consideran condiciones de trabajo o condiciones de empleo los permisos, licencias, capacitación, uniformes, ambiente de trabajo y, en general, todas aquellas que faciliten la actividad del servidor civil para el cumplimiento de sus funciones. $\left(^{*}\right)$

(*) De conformidad con el Resolutivo 2 del Pleno Jurisdiccional del Tribunal Constitucional Expedientes 0025-2013-PI-TC; 0003-2014-PI-TC; 0008-2014-PI-TC; 0017-2014-PI-TC, publicado el 04 mayo 2016, se declara infundada la demanda de inconstitucionalidad contra el presente literal, debiéndose INTERPRETAR, en el sentido que la expresión "condiciones de trabajo o condiciones de empleo" incluye también la materia remunerativa y otras materias con incidencia económica.

f) Firma de los dirigentes sindicales designados para tal fin por la asamblea, o de los representantes acreditados, de no haber sindicato.

Artículo 44. De la negociación colectiva

La negociación y los acuerdos en materia laboral se sujetan a lo siguiente:

a) El pliego de reclamos se presenta ante la entidad pública entre el 1 de noviembre y el 30 de enero del siguiente año. 
b) La contrapropuesta o propuestas de la entidad relativas a compensaciones económicas son nulas de pleno derecho. (*)

(*) Extremo declarado inconstitucional por el Literal d) del Resolutivo 1 del Pleno Jurisdiccional del Tribunal Constitucional Expedientes 0025-2013-PI-TC; 0003-2014-PI-TC; 0008-2014-PI-TC; 0017-2014-PI-TC, publicado el 04 mayo 2016, quedando redactado el numeral b) conforme al siguiente texto:

b) "La contrapropuesta o propuestas de la entidad relativas a compensaciones económicas son nulas de pleno derecho".

c) Las negociaciones deben efectuarse necesariamente hasta el último día del mes de febrero. Si no se llegara a un acuerdo, las partes pueden utilizar los mecanismos de conciliación hasta el 31 de marzo.

d) Los acuerdos suscritos entre los representantes de la entidad pública y de los servidores civiles tienen un plazo de vigencia no menor de dos (2) años y surten efecto obligatoriamente a partir del 1 de enero del ejercicio siguiente. Similar regla se aplica a los laudos arbitrales.

e) Los acuerdos y los laudos arbitrales no son de aplicación a los funcionarios públicos, directivos públicos ni a los servidores de confianza. Es nulo e inaplicable todo pacto en contrario.

Son nulos los acuerdos adoptados en violación de lo dispuesto en el presente artículo.

Están prohibidos de representar intereses contrarios a los del Estado en procesos arbitrales referidos a la materia de la presente Ley o en los casos previstos en el presente artículo quienes ejercen cargos de funcionarios o directivos públicos, incluso en los casos en que los mismos se realicen ad honorem o en órganos colegiados. Esta prohibición también alcanza a cualquiera que ejerza como árbitro o conciliador.

Artículo 45. Ejercicio de la huelga

45.1 El derecho de huelga se ejerce una vez agotados los mecanismos de negociación o mediación. Para tal efecto, los representantes del personal deben notificar a la entidad sobre el ejercicio del citado derecho con una anticipación no menor a quince (15) días. Es ilegal el ejercicio del derecho de huelga que no haya cumplido con lo establecido en el presente artículo.

45.2 El ejercicio del derecho de huelga permite a la entidad pública la contratación temporal y directa del personal necesario para garantizar la prestación de los servicios mínimos de los servicios esenciales y mínimos de los servicios indispensables para el funcionamiento de la entidad, desde el inicio de la huelga y hasta su efectiva culminación.

CONCORDANCIAS: $\quad$ D.S. N ${ }^{\circ}$ 040-2014-PCM, Art. 79 (Definición de Huelga)

D.S. $\mathrm{N}^{\circ}$ 040-2014-PCM, Art. 80 (Requisitos para la declaratoria de Huelga)

D.S. No 040-2014-PCM, Art. 81 (Huelga atípica)

D.S. N ${ }^{\circ}$ 040-2014-PCM, Art. 82 (Ámbito y vigencia de la huelga)

D.S. No 040-2014-PCM, Art. 83 (De los servicios indispensables)

\section{CAPÍTULO VII: CAUSAS DE SUSPENSIÓN Y TÉRMINO DEL SERVICIO CIVIL}

Artículo 46. Suspensión del Servicio Civil 
La suspensión del Servicio Civil es perfecta cuando cesa temporalmente la obligación del trabajador de prestar el servicio y la del empleador de otorgar la compensación respectiva, sin que desaparezca el vínculo laboral. Es imperfecta cuando el empleador debe otorgar la compensación sin contraprestación efectiva de labores.

CONCORDANCIAS: D.S. N 040-2014-PCM, Art. 192 (De la suspensión)

Artículo 47. Supuestos de suspensión

47.1 El Servicio Civil se suspende de manera perfecta en los siguientes casos:

a) La maternidad durante el descanso pre y postnatal. El pago del subsidio se abona de acuerdo a la ley de la materia.

b) El ejercicio de cargos políticos de elección popular o haber sido designado como funcionario público de libre designación y remoción que requieran desempeñarse a tiempo completo.

CONCORDANCIAS: D.S. N 040-2014-PCM, Art. 153 (Licencias)

D.S. N 040-2014-PCM, Art. 194 (Del ejercicio de cargos políticos)

c) El permiso o licencia concedidos por la entidad.

CONCORDANCIAS: D.S. N 040-2014-PCM, Art. 195 (Del permiso o licencia concedidos por la entidad)

d) El ejercicio del derecho de huelga.

CONCORDANCIAS: D.S. N 040-2014-PCM, Art. 196 (Del ejercicio del derecho de huelga)

e) La sanción por la comisión de faltas de carácter disciplinario que conlleve la suspensión temporal del servidor civil, así como la pena privativa de libertad efectiva por delito culposo por un período no mayor a tres (3) meses.

CONCORDANCIAS: D.S. N 040-2014-PCM, Art. 197 (De la suspensión temporal)

f) La inhabilitación para el ejercicio profesional o el ejercicio de la función pública, en ambos casos por un período no mayor a tres (3) meses.

g) La detención del servidor por la autoridad competente.

CONCORDANCIAS: D.S. Nº 040-2014-PCM, Art. 198 (La detención del servidor)

h) La sentencia de primera instancia por delitos de terrorismo, narcotráfico, corrupción o violación de la libertad sexual.

i) El caso fortuito o fuerza mayor, debidamente sustentado.

En los casos previstos en el literal h), de no confirmarse la sentencia contra el servidor, este puede reingresar al mismo nivel, una vez que dicha sentencia quede firme teniendo derecho a percibir únicamente las compensaciones económicas Principal y Ajustada, así como aguinaldos por Fiestas Patrias y Navidad; y Compensación por Tiempo de Servicios.

47.2 La relación de Servicio Civil se suspende de manera imperfecta en los siguientes casos: 
a) La enfermedad y el accidente comprobados, de acuerdo al plazo establecido en la normatividad sobre seguridad social en salud.

b) La invalidez temporal, de acuerdo al plazo establecido en la normatividad sobre seguridad social en salud.

c) El descanso vacacional.

d) El permiso y la licencia para el desempeño de cargos sindicales.

CONCORDANCIAS: D.S. N 040-2014-PCM, Art. 61 (De las licencias sindicales)

e) El permiso o licencia concedidos por la entidad, por cuenta o interés de la entidad.

f) Licencias por paternidad, conforme a la ley de la materia.

g) Por citación expresa judicial, militar, policial u otras citaciones derivadas de actos de administración interna de las entidades públicas.

CONCORDANCIAS: D.S. $\mathrm{N}^{\circ}$ 138-2014-EF (Reglamento de Compensaciones), Art. 16 (Requisitos para percibir los aguinaldos)

47.3 La participación en la formación para ser directivo público en la Escuela Nacional de Administración Pública puede originar suspensión perfecta o imperfecta según fuera el caso. La resolución debidamente fundamentada que autoriza la suspensión imperfecta se publica en el portal institucional de la respectiva entidad pública.

47.4 La imposición de una medida cautelar, de conformidad con las normas sobre el procedimiento sancionador disciplinario establecidos en la presente Ley y su Reglamento, puede originar suspensión perfecta o imperfecta según el caso.

CONCORDANCIAS: D.S. N 040-2014-PCM, Art. 178, inc. c) (Supuestos de Contratación Directa)

D.S. N 040-2014-PCM, Art. 192 (De la suspensión)

Artículo 48. Término del Servicio Civil

La relación laboral en el Servicio Civil termina con la conclusión del vínculo que une a la entidad con el servidor civil. Se sujeta a las causales previstas en la presente Ley.

Artículo 49. Causales de término del Servicio Civil

Son causales de término del Servicio Civil las siguientes:

a) Fallecimiento.

b) Renuncia.

c) Jubilación.

d) Mutuo acuerdo.

CONCORDANCIAS: $\quad$ D.S. N 040-2014-PCM, Art. 211 (Del término por mutuo acuerdo)

e) Alcanzar el límite de edad de setenta (70) años, exceptuando a aquellos funcionarios públicos de órganos colegiados cuya función es de asistencia temporal y perciben dieta. 
f) Pérdida o renuncia a la nacionalidad peruana, en los casos en que la naturaleza del puesto la exija como requisito para acceder al Servicio Civil.

g) La sanción de destitución por la comisión de faltas de carácter disciplinario y la condena penal por delito doloso; así como la pena privativa de libertad efectiva por delito culposo por un plazo mayor a tres (3) meses. (*)

(*) De conformidad con el Resolutivo 3 del Pleno Jurisdiccional del Tribunal Constitucional Expedientes 0025-2013-PI-TC; 0003-2014-PI-TC; 0008-2014-PI-TC; 0017-2014-PI-TC, publicado el 04 mayo 2016, se declara infundada la demanda de inconstitucionalidad contra el literal g), debiéndose INTERPRETAR, el mismo en el sentido que "Son causales de término del Servicio Civil las siguientes: la pena privativa de libertad efectiva por delito culposo vinculado con la actividad funcional del servidor por un plazo mayor a tres (3) meses".

CONCORDANCIAS: D.S. N 040-2014-PCM, Art. 213 (Término por condena penal) D.S. $N^{\circ}$ 040-2014-PCM, Art. 231 (Plazo de Apelación)

h) La inhabilitación para el ejercicio profesional o el ejercicio de la función pública, en ambos casos por un período mayor a tres (3) meses.

CONCORDANCIAS: D.S. N 040-2014-PCM, Art. 231 (Plazo de Apelación)

i) Cese por causa relativa a la capacidad del servidor en los casos de desaprobación.

CONCORDANCIAS: D.S. N 040-2014-PCM, Art. 231 (Plazo de Apelación)

j) No superar el período de prueba. La resolución administrativa que declare el cese debe estar debidamente motivada.

k) Supresión del puesto debido a causas tecnológicas, estructurales u organizativas, entendidas como las innovaciones científicas o de gestión o nuevas necesidades derivadas del cambio del entorno social o económico, que llevan cambios en los aspectos organizativos de la entidad. El decreto supremo, la resolución del Consejo Ejecutivo del Poder Judicial, la resolución del titular de la entidad constitucionalmente autónoma, y la ordenanza regional u ordenanza municipal que autoricen la supresión de puestos deben estar debidamente fundamentadas acreditando las causas y la excepcionalidad de su adopción, y contar con la opinión técnica favorable de Servir y de la Secretaría de Gestión Pública de la Presidencia del Consejo de Ministros (PCM), de modo previo a su aprobación. Dicha norma establece un plazo mínimo de seis (6) meses contados a partir de su publicación para ejecutar la supresión. Para efecto del reingreso, se les aplica lo dispuesto en el artículo 68 de la presente Ley.

CONCORDANCIAS: D.S. N N $^{\circ}$ 040-2014-PCM, Art. 217 (Supresión del puesto por causa tecnológica, estructural u organizativa)

$$
\text { D.S. N 040-2014-PCM, Art. } 231 \text { (Plazo de Apelación) }
$$

1) Extinción de la entidad por mandato normativo expreso. El decreto supremo y la ordenanza regional u ordenanza municipal que autoricen la extinción de la entidad, programa o proyecto deben estar debidamente fundamentadas acreditando las causas y la excepcionalidad de su adopción, y contar con la opinión técnica favorable de Servir y de la Secretaría de Gestión Pública de la PCM, de modo previo a su aprobación. Dicha norma establece un plazo mínimo de seis (6) meses contados a partir de su publicación para ejecutar la extinción. Para efecto del reingreso se aplica lo dispuesto en el artículo 68 de la presente Ley. 
m) Por decisión discrecional, en el caso de los servidores civiles de confianza y funcionarios públicos de libre nombramiento y remoción.

n) Cese por causa relativa a la incapacidad física o mental sobreviniente del servidor que impida el ejercicio de las funciones que le corresponden. Debe declararse conforme a Ley.

CONCORDANCIAS: D.S. $\mathrm{N}^{\circ}$ 040-2014-PCM, Art. 220 (Término por causa relativa a la incapacidad física o mental sobreviniente)

ñ) De manera facultativa para el servidor, alcanzar la edad de sesenta y cinco (65) años.

Artículo 50. La impugnación de la suspensión y término del Servicio Civil

Todo proceso de impugnación previsto en la presente Ley o que derive de lo previsto en ella se desarrolla con respeto al debido procedimiento y se sujeta a las siguientes condiciones:

a) Se realiza en una vía procedimental previamente establecida.

b) Se sujeta a plazos perentorios y de prescripción.

c) Se realiza por escrito.

d) No requiere firma de abogado colegiado.

\section{TÍTULO IV: DE LOS GRUPOS DE SERVIDORES CIVILES DEL SERVICIO CIVIL}

\section{CAPÍTULO I: DE LOS FUNCIONARIOS PÚBLICOS}

Artículo 51. Atribuciones del funcionario público

El funcionario público ejerce atribuciones políticas, normativas y administrativas. Las dos primeras son entendidas como la facultad de diseñar y aprobar políticas y normas o reglas de carácter general, en el ámbito y las materias de su competencia. La tercera es entendida como actos de dirección y de gestión interna.

Artículo 52. Clasificación de los funcionarios públicos

Los funcionarios públicos se clasifican en:

a) Funcionarlo público de elección popular, directa y universal. Es el elegido mediante elección popular, directa y universal, como consecuencia de un proceso electoral conducido por la autoridad competente para tal fin. El ingreso, permanencia y término de su función están regulados por la Constitución Política del Perú y las leyes de la materia.

Son funcionarios públicos de elección popular, directa y universal:

1) Presidente de la República.

2) Vicepresidentes de la República.

3) Congresistas de la República y del Parlamento Andino.

4) Presidentes, Vicepresidentes y Consejeros Regionales.

5) Alcaldes, Teniente Alcaldes y Regidores.

b) Funcionario público de designación o remoción regulada. Es aquel cuyos requisitos, proceso de acceso, período de vigencia o causales de remoción están regulados en norma especial con rango de ley.

Son funcionarios públicos de designación y remoción regulados:

1) Magistrados del Tribunal Constitucional.

2) Defensor del Pueblo y Defensor adjunto. 
3) Contralor General de la República y Vicecontralor.

4) Presidente y miembros del Jurado Nacional de Elecciones.

5) Miembros del Consejo Nacional de la Magistratura.

6) Director General y miembros del Consejo Directivo de la Academia de la Magistratura.

7) Titulares, adjuntos, presidentes y miembros de órganos colegiados de los organismos constitucionalmente autónomos.

8) Titulares, adjuntos y miembros de órganos colegiados de entidades que cuenten con disposición expresa sobre la designación de sus funcionarios.

9) Los jueces que integren el Consejo Ejecutivo del Poder Judicial.

10) Fiscal de la Nación del Ministerio Público.

11) Presidente de la Corte Suprema

12) Rectores y vicerrectores de las universidades públicas.

13) Titulares, adjuntos, presidente y miembros del consejo directivo de los organismos técnicos especializados y reguladores y tribunales administrativos.

14) Gobernadores.

15) Aquellos señalados por norma con rango de ley, siempre que cumplan con lo dispuesto en los artículos 53 y 54 de la presente Ley.

c) Funcionario público de libre designación y remoción. Es aquel cuyo acceso al Servicio Civil se realiza por libre decisión del funcionario público que lo designa, basada en la confianza para realizar funciones de naturaleza política, normativa o administrativa.

Son funcionarios públicos de libre designación y remoción:

1) Ministros de Estado.

2) Viceministros.

3) Secretarios generales de Ministerios y aquellos que por ley expresa tengan igual jerarquía.

4) Titulares, adjuntos, presidentes y miembros de los órganos colegiados de libre designación y remoción.

5) Gerente General del Gobierno Regional.

6) Gerente Municipal.

La Compensación Económica para los funcionarios señalados en el presente artículo se aprueba mediante decreto supremo con el voto aprobatorio del Consejo de Ministros, excepto para los congresistas de la República y los parlamentarios andinos cuyos ingresos son fijados de 
conformidad con lo dispuesto en el artículo 94 de la Constitución Política del Perú y el artículo 31 de la presente Ley. $(*)$

(*) De conformidad con la Septuagésima Novena Disposición Complementaria Final de la Ley $\mathrm{N}^{\circ}$ 30372, publicada el 06 diciembre 2015, se dispone que la implementación del decreto supremo a que hace referencia el último párrafo del presente artículo, se encuentra sujeta a la emisión de la resolución de inicio del proceso de implementación, la aprobación del Cuadro de Puestos de la Entidad - CPE y la presentación del Plan de Implementación, al que hace referencia la Directiva 002-2015-SERVIR-GDSRH "Normas para la Gestión del Proceso de Administración de Puestos, y Elaboración y Aprobación del Cuadro de Puestos de la Entidad CPE", en las entidades que correspondan. Para efectos de la aprobación del referido decreto supremo, las entidades quedan exoneradas de lo establecido en los artículos 6 y 9 de la presente Ley y las prohibiciones contenidas en la Ley 28212 y sus modificatorias. La referida disposición entra en vigencia a partir del 1 de enero de 2016.

CONCORDANCIAS: Ley N 30114, Centésima Quinta Disp. Comp. Final

D.S. $\quad \mathrm{N}^{\circ}$ 023-2014-EF, (Aprueban montos por concepto de Compensaciones Económicas a Funcionarios Públicos de la Ley $N^{\circ} 30057$, Ley del Servicio Civil), Art. 1

D.S. $\mathrm{N}^{\circ}$ 040-2014-PCM, Art. 161 (De la incorporación al servicio civil)

Artículo 53. Requisitos de los funcionarios públicos

Para ser funcionario público se requiere cumplir con los requisitos contemplados para cada puesto según la ley especifica. Sin perjuicio de ello, se requiere:

a) Tener la nacionalidad peruana, en los casos en que la naturaleza del puesto lo exija, conforme a la Constitución Política del Perú y a las leyes específicas.

b) Tener hábiles sus derechos civiles.

c) No estar inhabilitado para ejercer función pública o para contratar con el Estado, de acuerdo a resolución administrativa o resolución judicial definitiva.

d) No tener condena por delito doloso.

e) No tener otro impedimento legal establecido por norma expresa de alcance general.

Artículo 54. Requisitos mínimos para funcionarios de libre designación o remoción

Los funcionarios públicos de libre designación o remoción deben contar con estudios superiores o experiencia, así como cumplir con los requisitos mínimos establecidos para el puesto, de acuerdo a lo señalado en los documentos de gestión de la entidad o en la norma correspondiente.

Artículo 55. Causales de terminación de la condición o calidad de funcionario público de libre designación o remoción

Sin perjuicio de lo dispuesto en el artículo 49, la condición o calidad de funcionario público de libre designación o remoción concluye, adicionalmente, por:

a) Cumplimiento del plazo de designación.

b) Pérdida de la confianza o decisión unilateral de la autoridad que lo designó, para los casos de funcionarios públicos de libre designación y remoción.

Las normas reglamentarias desarrollarán las causales de cese de la designación en los casos de funcionarios públicos de designación y remoción regulados. 
Artículo 56. Efectos del término de la designación como funcionario público

El término del vínculo jurídico del funcionario público con la entidad no genera pago compensatorio, otorgamiento de suma a título de liberalidad ni indemnización alguna, salvo la CTS, de corresponder.

Artículo 57. Aplicación general de la presente Ley a funcionarios

En el caso de los funcionarios públicos, la presente Ley y sus normas reglamentarias se aplican según la naturaleza de sus actividades.

\section{CAPÍTULO II: DIRECTIVOS PÚBLICOS}

Artículo 58. Funciones de los directivos públicos

El directivo público tiene funciones de organización, dirección o toma de decisiones sobre los recursos a su cargo; vela por el logro de los objetivos asignados y supervisa el logro de metas de los servidores civiles bajo su responsabilidad.

Artículo 59. Incorporación y asignación de puestos a los directivos públicos

El ingreso a un puesto directivo público se realiza por concurso público de méritos realizado por cada entidad, cumpliendo con el perfil del puesto respectivo. En el caso de los servidores de confianza, aun cuando no se requiere concurso, deben cumplir con el perfil establecido para el puesto.

Los directivos públicos son asignados para desempeñar puestos hasta el tercer nivel orgánico consecutivo de la entidad. Mediante resolución del titular de Servir se pueden establecer excepciones a esta regla, en función del número de niveles organizativos de la entidad, el número total de servidores de la entidad o la naturaleza de las funciones de la entidad.

Artículo 60. Características de la contratación de directivos públicos

60.1 Los directivos públicos son designados por un período de tres (3) años, renovables hasta en dos (2) oportunidades, con excepción de quienes ejerzan la titularidad de entes rectores de sistemas administrativos, a los que no se aplica el límite de renovaciones.

60.2 En todos los casos las renovaciones se realizan considerando los resultados favorables de su evaluación anual.

60.3 Los plazos se computan por cada puesto ocupado por el directivo público.

60.4 Están sujetos a un período de prueba no menor de tres (3) ni mayor de seis (6) meses y a la evaluación anual de cumplimiento de metas de carácter institucional.

60.5 Autorizase a Servir para que, en los casos que se le delegue, realice los concursos de selección de directivos en representación de las entidades comprendidas en el régimen de la presente Ley.

Artículo 61. Obligaciones del directivo público

Sin perjuicio de lo dispuesto en la presente Ley, el directivo público está obligado a:

a) Lograr las metas establecidas para el período de su designación, dentro de las circunstancias y recursos existentes, y rendir cuenta de ello. transparencia.

b) Realizar las acciones y los procesos propios de su cargo con eficiencia, efectividad y 
Artículo 62. De la evaluación de desempeño

La evaluación de desempeño de los directivos públicos se centra en la verificación y calificación del cumplimiento de metas definidas para el directivo público en el período de gestión, así como en la identificación de brechas de conocimientos y habilidades. Es anual e incluye a quienes están sujetos a la condición de confianza.

Los tipos de evaluación asociados al cumplimiento de la función son la medición del logro de metas y la medición de competencias. Si el directivo público no logra cumplir con las metas establecidas para la evaluación, de acuerdo con los criterios previstos en las normas reglamentarias, la entidad da por concluida la designación.

Artículo 63. Causales de término de la condición o calidad de directivo público

Sin perjuicio de lo dispuesto en el artículo 49 de la presente Ley, la condición o calidad de directivo público concluye por:

a) Incumplimiento de metas, según lo establecido en los artículos 61 y 62 de la presente

Ley.

b) Vencimiento del plazo del contrato.

c) Asunción de cargo de funcionario público o de servidor de confianza.

El término por estas causales no da lugar a ninguna medida compensatoria ni indemnización a favor del directivo público, salvo aquellas establecidas en la presente Ley.

Artículo 64. Número de directivos de confianza en la entidad pública

Sólo el veinte por ciento (20\%) de los directivos públicos existentes en cada entidad pública puede ser ocupado por servidores de confianza, respetando el porcentaje previsto en el artículo 77 de la presente Ley.

Mediante resolución de Presidencia Ejecutiva, Servir establece otros límites en consideración al número total de servidores civiles previstos en el cuadro de puestos de la entidad (CPE), así como a la naturaleza o funciones de la entidad, entre otros factores.

Cada tres (3) años Servir publica la lista de directivos públicos existentes en cada entidad y aquellas plazas que puedan ser ocupadas por servidores de confianza.

\section{CAPÍTULO III: SERVIDORES CIVILES DE CARRERA}

Artículo 65. Funciones del servidor civil de carrera

El servidor civil de carrera realiza actividades directamente vinculadas al cumplimiento de las funciones sustantivas y de administración interna de una entidad pública en el ejercicio de una función administrativa, la prestación de servicios públicos, o la gestión institucional. El Servicio Civil de Carrera es un sistema único e integrado.

No comprende a los funcionarios, los directivos públicos, los servidores de confianza, los servidores de servicios complementarios ni los contratados temporalmente.

Artículo 66. Características de la contratación de los servidores civiles

Los servidores civiles de carrera se incorporan al régimen del Servicio Civil por un período indeterminado y están sujetos únicamente a las causales de suspensión y término establecidas en los artículos 47 y 49 de la presente Ley. 
El servidor civil de carrera que haya sido seleccionado o designado como funcionario público o directivo público y no haya superado el período de prueba, haya perdido la confianza o haya culminado el período a que se refiere el numeral 60.1 del artículo 60 de la presente Ley, retorna al grupo y nivel primigenio.

El servidor civil de carrera designado como funcionario público o directivo público, ya sea por confianza o por concurso público, tiene suspendidas sus oportunidades de progresión hasta el término de la referida designación y su retorno al grupo y nivel primigenio.

Artículo 67. Incorporación al grupo de servidores civiles de carrera

La incorporación al grupo de servidores civiles de carrera se efectúa mediante concurso público de méritos abierto o transversal.

El concurso público de méritos transversal es el proceso por el que se accede a un puesto distinto en la propia entidad o en una entidad diferente y al que sólo pueden postular los servidores civiles de carrera, siempre que cumplan con el perfil del puesto.

El concurso público de méritos abierto es el proceso por el que se accede a un puesto propio de la carrera pública y al que puede postular cualquier persona sea o no servidor civil de carrera siempre que cumpla con el perfil del puesto.

El concurso público de méritos abierto procede:

a) Cuando se requiere cubrir puestos que corresponden al nivel inicial de una familia de puestos.

b) Cuando se produzca una plaza vacante de puestos altamente especializados. El puesto puede ubicarse en cualquier nivel de la entidad convocante.

c) Cuando se trate de entidades nuevas, para cubrir los puestos de todos los niveles organizacionales de la entidad.

d) Cuando resulte desierto el concurso transversal a nivel de todo el Estado.

Artículo 68. Reingreso

Los servidores civiles de carrera que renuncien pueden reingresar al Servicio Civil de Carrera en el mismo nivel o en un nivel superior, siempre que ganen el concurso público de méritos transversal convocado para el puesto al que postulen.

El reingreso debe producirse dentro de los dos (2) años posteriores a la renuncia.

Artículo 69. Progresión de los servidores civiles de carrera

La progresión implica que el servidor de carrera accede a un puesto vacante en cualquier entidad pública incluyendo la propia, a través de un concurso público de méritos transversal.

Se efectúa a un puesto:

a) Del mismo nivel o superior, dentro de una misma familia de puestos.

b) Del mismo nivel, superior o inferior en otra familia de puestos.

La progresión puede ocurrir hasta en dos (2) niveles superiores, respecto del nivel en que se encuentra el servidor civil.

Artículo 70. Consecuencia de la progresión 
El servidor civil de carrera que gane el concurso público de méritos transversal solo tiene derecho a las compensaciones y a las prerrogativas establecidas para el puesto concursado $\mathrm{y}$ en tanto se mantenga en dicho puesto.

Cada oportunidad de progresión genera derechos diferentes y no acumulables, con excepción del tiempo de servicios. La progresión únicamente da lugar al otorgamiento de la compensación del puesto concursado.

Artículo 71. Requisito para participar en un concurso público de méritos transversal

Para participar en un concurso público de méritos transversal el servidor civil de carrera debe cumplir, como mínimo, un tiempo de permanencia de dos (2) años en su puesto; y contar con, al menos, una calificación de "personal de buen rendimiento" en las evaluaciones de los últimos dos (2) años.

Artículo 72. Período de prueba del servidor civil de carrera

El servidor civil de carrera que se incorpora mediante concurso público se sujeta a un período de prueba de tres (3) meses.

Artículo 73. Suplencia en el período de prueba

El puesto que deja un servidor civil de carrera que se encuentra en período de prueba por progresión sólo puede ser cubierto por contrato temporal de suplencia, el cual se realiza directamente, sin concurso y por el plazo que dure el período de prueba.

El contrato temporal de suplencia por período de prueba puede extenderse por el tiempo adicional que tome realizar el concurso para cubrir el puesto dejado por el servidor que superó el período de prueba.

Los servicios prestados bajo la condición de contratación temporal de suplencia no generan derechos adicionales a los establecidos contractualmente. Tampoco generan derecho para el ingreso al Servicio Civil de Carrera o permanencia en el puesto.

CONCORDANCIAS: D.S. N 040-2014-PCM, Art. 178, inc. b) (Supuestos de Contratación Directa)

fijo)

D.S. N ${ }^{\circ}$ 040-2014-PCM, Art. 221 (Término de la contratación a plazo

\section{CAPÍTULO IV: SERVIDORES DE ACTIVIDADES COMPLEMENTARIAS}

Artículo 74. Funciones de los servidores de actividades complementarias

Los servidores de actividades complementarias realizan funciones de soporte, complemento, manuales u operativas respecto de las funciones sustantivas y de administración interna que realiza cada entidad.

Artículo 75. Incorporación y período de prueba

Los servidores de actividades complementarias ingresan mediante concurso público de méritos. Para los casos de convocatorias a procesos de selección a plazo indeterminado, el ganador del concurso público de méritos pasa por un período de prueba que no puede ser mayor a tres (3) meses. En caso el servidor de actividades complementarias no supere el período de prueba, la relación con el Servicio Civil termina.

Artículo 76. Modalidades de contratación

Los servidores civiles de actividades complementarias son contratados a plazo indeterminado o a plazo fijo. 
Los contratos a plazo fijo requieren período de prueba y proceden para la ejecución de proyectos o servicios específicos. El período de prueba en esta modalidad de contratación se aplica solo para el primer contrato respecto del mismo puesto y no para las renovaciones. Los contratos culminan con la terminación del proyecto o servicio específico, el cumplimiento de la condición resolutoria o el vencimiento del plazo previsto en el contrato.

CONCORDANCIAS: D.S. N 040-2014-PCM, Art. 221 (Término de la contratación a plazo fijo)

\section{CAPÍTULO V: DE LOS SERVIDORES DE CONFIANZA}

Artículo 77. Límite de servidores de confianza

El número de servidores de confianza en ningún caso es mayor al cinco por ciento (5\%) del total de puestos previstos por la entidad pública, con un mínimo de dos (2) y un máximo de cincuenta (50) servidores de confianza, correspondiendo al titular de la entidad pública la determinación de la ubicación de los servidores de confianza. Este porcentaje incluye a los directivos públicos a que se refiere el artículo 64 de la presente Ley.

Las normas reglamentarias regulan la forma de calcular los topes mínimos y máximos, atendiendo al número total de servidores civiles previstos en la entidad pública y a la naturaleza o funciones de la entidad pública, entre otros factores.

Mediante resolución de Presidencia Ejecutiva debidamente justificada, Servir establece las excepciones, debidamente justificadas a los topes (mínimos o máximos) señalados en el presente artículo. Esta resolución se publica en el diario oficial El Peruano.

Artículo 78. Consecuencias del incumplimiento de los límites de servidores de confianza

La inobservancia del porcentaje autorizado para la incorporación de servidores de confianza o el incumplimiento de los topes a que se refiere el artículo 77 de la presente Ley, no genera a favor de los contratados el derecho a permanencia ni beneficio distinto a la compensación que corresponda por los servicios prestados.

De detectarse la violación de los límites establecidos se procede a dar por terminado el contrato o designación de todos los servidores excedentes, sin perjuicio de la responsabilidad que corresponda a los encargados de la gestión de los recursos humanos de la entidad pública, por incumplimiento de las disposiciones de esta Ley.

Artículo 79. De la contratación y designación

El vínculo entre los servidores de confianza y la entidad se establece en un contrato escrito de naturaleza temporal, cuya vigencia se condiciona a la confianza de quien los designa, y donde se precisan las condiciones de empleo, el puesto a ocupar y la contraprestación a percibir, conforme a lo establecido en el artículo 31 de la presente Ley.

El contrato puede resolverse, sin que ello genere el derecho a pago compensatorio, otorgamiento de suma a título de liberalidad ni indemnización alguna por la terminación del vínculo con la entidad pública.

La designación de servidores de confianza se realiza mediante el acto administrativo que corresponda de acuerdo a ley o mediante el acto de administración contemplado en la presente Ley, según sea el caso. Dicha designación debe ser publicada en la página web de la entidad. 


\section{CAPÍTULO VI: DISPOSICIONES COMUNES PARA LOS DIRECTIVOS PÚBLICOS, SERVIDORES DE CARRERA Y SERVIDORES DE ACTIVIDADES COMPLEMENTARIAS}

Artículo 80. Del accesitario

El postulante que apruebe el concurso y a pesar de su calificación de apto no alcance vacante, se convierte en accesitario. Sólo habrá un accesitario por puesto concursado.

En caso que el ganador del correspondiente proceso de selección no pudiera acceder al puesto obtenido o no hubiera superado el período de prueba, la entidad puede cubrir el puesto vacante con el accesitario.

La condición de accesitario sólo es de aplicación respecto del puesto convocado y se extingue automáticamente en los casos en que el ganador del puesto supere el período de prueba o a los seis (6) meses de concluido el concurso.

La condición de accesitario no da lugar a ningún derecho para el postulante, ni lo incorpora en forma alguna al Servicio Civil.

Artículo 81. Desplazamiento

El desplazamiento de personal es el acto de administración mediante el cual un servidor civil, por disposición fundamentada de la entidad pública, pasa a desempeñar temporalmente diferentes funciones dentro o fuera de su entidad, teniendo en consideración las necesidades del Servicio Civil y el nivel ostentado.

Los desplazamientos son:

a) Designación como directivo público o como servidor de confianza.

b) Rotación.

c) Destaque.

d) Encargo de funciones.

e) Comisión de servicios.

Artículo 82. Participación de las carreras especiales

82.1 Los servidores civiles pertenecientes a las carreras especiales pueden ocupar puestos definidos para el servidor civil de carrera, servidores de actividades complementarias o directivos públicos, en tanto cumplan los requisitos del puesto y bajo las modalidades de ingreso previstas en la presente Ley.

82.2 Al asumir los referidos puestos, los derechos, obligaciones, reglas y demás disposiciones y regulaciones propias de las carreras especiales, quedan suspendidas hasta su retorno al puesto de su carrera. Al término retornan a su carrera especial.

82.3 En tanto ocupen los citados puestos, se regirán exclusivamente por lo dispuesto en la presente Ley y sus normas reglamentarias y complementarias.

Artículo 83. Nepotismo

Los servidores civiles incluyendo a los funcionarios que gozan de la facultad de nombramiento y contratación de personal o tengan injerencia directa o indirecta en el proceso de selección o contratación de personas, están prohibidos de ejercer dicha facultad en su entidad respecto a sus parientes hasta el cuarto grado de consanguinidad, segundo de afinidad y por razón de matrimonio. Son nulos los contratos o designaciones que se realicen en contravención de lo dispuesto en este artículo. 
Se aplica las mismas reglas en el caso de convivientes o uniones de hecho.

Artículo 84. Contratación temporal

Excepcionalmente se puede contratar de manera directa a plazo fijo en los casos de suspensión previstos en el artículo 47 de la presente Ley, así como en los casos de incremento extraordinario y temporal de actividades. Estas situaciones deben estar debidamente justificadas. Los contratos no pueden tener un plazo mayor a nueve (9) meses. Pueden renovarse por una sola vez antes de su vencimiento, hasta por un período de tres (3) meses. Cumplido el plazo, tales contratos concluyen de pleno derecho y son nulos los actos en contrario. El personal contratado bajo esta modalidad no pertenece al Servicio Civil de Carrera.

CONCORDANCIAS: D.S. N 040-2014-PCM, Art. 221 (Término de la contratación a plazo fijo)

\section{TÍTULO V: RÉGIMEN DISCIPLINARIO Y PROCEDIMIENTO SANCIONADOR}

\section{CAPÍTULO I: FALTAS}

Artículo 85. Faltas de carácter disciplinario

Son faltas de carácter disciplinario que, según su gravedad, pueden ser sancionadas con suspensión temporal o con destitución, previo proceso administrativo:

a) El incumplimiento de las normas establecidas en la presente Ley y su reglamento.

b) La reiterada resistencia al cumplimiento de las órdenes de sus superiores relacionadas con sus labores.

c) El incurrir en acto de violencia, grave indisciplina o faltamiento de palabra en agravio de su superior del personal jerárquico y de los compañeros de labor.

d) La negligencia en el desempeño de las funciones.

e) El impedir el funcionamiento del servicio público. de terceros.

f) La utilización o disposición de los bienes de la entidad pública en beneficio propio o

g) La concurrencia al trabajo en estado de embriaguez o bajo la influencia de drogas o sustancias estupefacientes.

h) El abuso de autoridad, la prevaricación o el uso de la función con fines de lucro. (*)

(*) Literal declarado inconstitucional por el Literal j) del Resolutivo 1 del Pleno Jurisdiccional del Tribunal Constitucional Expedientes 0025-2013-PI-TC; 0003-2014-PI-TC; 0008-2014-PITC; 0017-2014-PI-TC, publicado el 04 mayo 2016, quedando redactado de la siguiente manera:

"h) El abuso de autoridad o el uso de la función con fines de lucro".

i) El causar deliberadamente daños materiales en los locales, instalaciones, obras, maquinarias, instrumentos, documentación y demás bienes de propiedad de la entidad o en posesión de ésta.

j) Las ausencias injustificadas por más de tres (3) días consecutivos o por más de cinco (5) días no consecutivos en un período de treinta (30) días calendario, o más de quince (15) días no consecutivos en un período de ciento ochenta días (180) calendario. 
k) El hostigamiento sexual cometido por quien ejerza autoridad sobre el servidor civil, así como el cometido por un servidor civil, cualquiera sea la ubicación de la víctima del hostigamiento en la estructura jerárquica de la entidad pública.

1) Realizar actividades de proselitismo político durante la jornada de trabajo, o a través del uso de sus funciones o de recursos de la entidad pública.

m) Discriminación por razón de origen, raza, sexo, idioma, religión, opinión o condición económica.

n) El incumplimiento injustificado del horario y la jornada de trabajo.

CONCORDANCIAS: $\quad$ Ley $\mathrm{N}^{\circ}$ 30119, Art. 5 (Uso indebido de la licencia)

ñ) La afectación del principio de mérito en el acceso y la progresión en el servicio civil. terceros.

o) Actuar o influir en otros servidores para obtener un beneficio propio o beneficio para

p) La doble percepción de compensaciones económicas, salvo los casos de dietas y función docente.

q) Las demás que señale la ley.

CONCORDANCIAS: D.S. N 040-2014-PCM, Art. 98 (Faltas que determinan aplicación de sanción disciplinaria)

Artículo 86. Régimen de los exservidores de las entidades

Los exservidores civiles de una entidad se acogen a las restricciones establecidas en el artículo 241 de la Ley 27444, Ley del Procedimiento Administrativo General.

Artículo 87. Determinación de la sanción a las faltas

La sanción aplicable debe ser proporcional a la falta cometida y se determina evaluando la existencia de las condiciones siguientes: el Estado.

a) Grave afectación a los intereses generales o a los bienes jurídicamente protegidos por

b) Ocultar la comisión de la falta o impedir su descubrimiento.

c) El grado de jerarquía y especialidad del servidor civil que comete la falta, entendiendo que cuanto mayor sea la jerarquía de la autoridad y más especializadas sus funciones, en relación con las faltas, mayor es su deber de conocerlas y apreciarlas debidamente.

d) Las circunstancias en que se comete la infracción.

e) La concurrencia de varias faltas.

f) La participación de uno o más servidores en la comisión de la falta o faltas.

g) La reincidencia en la comisión de la falta.

h) La continuidad en la comisión de la falta. 
i) El beneficio ilícitamente obtenido, de ser el caso.

Las autoridades deben prever que la comisión de la conducta sancionable no resulte más ventajosa para el infractor que cumplir las normas infringidas o asumir la sanción.

La destitución acarrea la inhabilitación automática para el ejercicio de la función pública. El servidor civil que se encuentre en este supuesto, no puede reingresar a prestar servicios a favor del Estado por un plazo de cinco (5) años, contados a partir de que la resolución administrativa que causa estado es eficaz.

Si un servidor civil es declarado responsable de un delito doloso, mediante sentencia que cause estado, o que haya quedado consentida, o ejecutoriada, culmina su relación con la entidad.

CONCORDANCIAS: D.S. $\mathrm{N}^{\circ}$ 040-2014-PCM, Art. 103 (Determinación de la sanción aplicable)

\section{CAPÍTULO II: RÉGIMEN DE SANCIONES Y PROCEDIMIENTO SANCIONADOR}

Artículo 88. Sanciones aplicables

Las sanciones por faltas disciplinarias pueden ser:

a) Amonestación verbal o escrita.

b) Suspensión sin goce de remuneraciones desde un día hasta por doce (12) meses.

c) Destitución.

Toda sanción impuesta al servidor debe constar en el legajo.

Artículo 89. La amonestación

La amonestación es verbal o escrita. La amonestación verbal la efectúa el jefe inmediato en forma personal y reservada. Para el caso de amonestación escrita la sanción se aplica previo proceso administrativo disciplinario. Es impuesta por el jefe inmediato. La sanción se oficializa por resolución del jefe de recursos humanos o quien haga sus veces. La apelación es resuelta por el jefe de recursos humanos o quien haga sus veces.

CONCORDANCIAS: D.S. $\mathrm{N}^{\circ}$ 040-2014-PCM, Art. 95 (Competencia para ejercicio de potestad disciplinaria en segunda instancia)

Artículo 90. La suspensión y la destitución

La suspensión sin goce de remuneraciones se aplica hasta por un máximo de trescientos sesenta y cinco (365) días calendario previo procedimiento administrativo disciplinario. El número de días de suspensión es propuesto por el jefe inmediato y aprobado por el jefe de recursos humanos o quien haga sus veces, el cual puede modificar la sanción propuesta. La sanción se oficializa por resolución del jefe de recursos humanos o quien haga su veces. La apelación es resuelta por el Tribunal del Servicio Civil.

La destitución se aplica previo proceso administrativo disciplinario por el jefe de recursos humanos o quien haga sus veces. Es propuesta por el jefe de recursos humanos o quien haga sus veces y aprobada por el titular de la entidad pública, el cual puede modificar la sanción propuesta. Se oficializa por resolución del titular de la entidad pública. La apelación es resuelta por el Tribunal del Servicio Civil.

Artículo 91. Graduación de la sanción 
Los actos de la Administración Pública que impongan sanciones disciplinarias deben estar debidamente motivados de modo expreso y claro, identificando la relación entre los hechos y las faltas, y los criterios para la determinación de la sanción establecidos en la presente Ley.

La sanción corresponde a la magnitud de las faltas, según su menor o mayor gravedad. Su aplicación no es necesariamente correlativa ni automática. En cada caso la entidad pública debe contemplar no sólo la naturaleza de la infracción sino también los antecedentes del servidor.

Los descuentos por tardanzas e inasistencia no tienen naturaleza disciplinaria, por lo que no eximen de la aplicación de la debida sanción.

CONCORDANCIAS: D.S. $\mathrm{N}^{\circ}$ 040-2014-PCM, Art. 103 (Determinación de la sanción aplicable)

Artículo 92. Autoridades

Son autoridades del procedimiento administrativo disciplinario:

a) El jefe inmediato del presunto infractor.

b) El jefe de recursos humanos o quien haga sus veces.

c) El titular de la entidad.

d) El Tribunal del Servicio Civil.

Las autoridades del procedimiento cuentan con el apoyo de un secretario técnico, que es de preferencia abogado y designado mediante resolución del titular de la entidad. El secretario técnico puede ser un servidor civil de la entidad que se desempeña como tal, en adición a sus funciones. El secretario técnico es el encargado de precalificar las presuntas faltas, documentar la actividad probatoria, proponer la fundamentación y administrar los archivos emanados del ejercicio de la potestad sancionadora disciplinaria de la entidad pública. No tiene capacidad de decisión y sus informes u opiniones no son vinculantes.

La secretaría técnica depende de la oficina de recursos humanos de la entidad o la que haga sus veces.

Cualquier persona que considere que un servidor civil ha incurrido en una conducta que tenga las características de falta disciplinaria, debe informarlo de manera verbal o escrita ante la Secretaría Técnica. La denuncia debe expresar claramente los hechos y adjuntar las pruebas pertinentes.

Artículo 93. El procedimiento administrativo disciplinario

93.1 La autoridad del procedimiento administrativo disciplinario de primera instancia inicia el procedimiento de oficio o a pedido de una denuncia, debiendo comunicar al servidor por escrito las presuntas faltas y otorgarle un plazo de cinco (5) días hábiles para presentar el descargo y las pruebas que crea conveniente para su defensa. Para tal efecto, el servidor civil tiene derecho a conocer los documentos y antecedentes que dan lugar al procedimiento. resuelto.

Vencido el plazo sin la presentación de los descargos, el proceso queda listo para ser

Cuando la comunicación de la presunta falta es a través de una denuncia, el rechazo a iniciar un proceso administrativo disciplinario debe ser motivado y notificado al que puso en conocimiento la presunta falta, si estuviese individualizado. 
93.2 Previo al pronunciamiento de las autoridades del proceso administrativo disciplinario de primera instancia y luego de presentado los descargos, el servidor civil procesado puede ejercer su derecho de defensa a través de un informe oral, efectuado personalmente o por medio de un abogado, para lo cual se señala fecha y hora única.

93.3 La autoridad del procedimiento administrativo disciplinario de primera instancia realiza las investigaciones del caso, solicita los informes respectivos, examina las pruebas que se presenten e impone las sanciones que sean de aplicación.

93.4 Durante el tiempo que dura el procedimiento administrativo disciplinario el servidor civil procesado, según la falta cometida, puede ser separado de su función y puesto a disposición de la oficina de recursos humanos. Mientras se resuelve su situación, el servidor civil tiene derecho al goce de sus remuneraciones, estando impedido de hacer uso de sus vacaciones, licencias por motivos particulares mayores a cinco (5) días o presentar renuncia.

CONCORDANCIAS: D.S. Nº 041-2014-PCM, Art. 25 (Amonestación escrita)

Artículo 94. Prescripción

La competencia para iniciar procedimientos administrativos disciplinarios contra los servidores civiles decae en el plazo de tres (3) años contados a partir de la comisión de la falta y uno (1) a partir de tomado conocimiento por la oficina de recursos humanos de la entidad, o de la que haga sus veces.

La autoridad administrativa resuelve en un plazo de treinta (30) días hábiles. Si la complejidad del procedimiento ameritase un mayor plazo, la autoridad administrativa debe motivar debidamente la dilación. En todo caso, entre el inicio del procedimiento administrativo disciplinario y la emisión de la resolución no puede transcurrir un plazo mayor a un (1) año.

Para el caso de los exservidores civiles, el plazo de prescripción es de dos (2) años contados a partir de que la entidad conoció de la comisión de la infracción.

Artículo 95. El procedimiento de los medios impugnatorios

95.1 El término perentorio para la interposición de los medios impugnatorios es de quince (15) días hábiles, y debe resolverse en el plazo de treinta (30) días hábiles. La resolución de la apelación agota la vía administrativa.

95.2 La interposición de los medios impugnatorios no suspende la ejecución del acto impugnado.

95.3 El recurso de apelación se interpone cuando la impugnación se sustente en diferente interpretación de las pruebas producidas, se trate de cuestiones de puro derecho o se cuente con nueva prueba instrumental. Se dirige a la misma autoridad que expidió el acto que se impugna para que eleve lo actuado al superior jerárquico. La apelación es sin efecto suspensivo.

\section{Artículo 96. Medidas cautelares}

96.1 Luego de comunicar por escrito al servidor civil sobre las presuntas faltas, la autoridad del proceso administrativo disciplinario puede, mediante decisión motivada, y con el objeto de prevenir afectaciones mayores a la entidad pública o a los ciudadanos, separarlo de su función y ponerlo a disposición de la Oficina de Personal para realizar trabajos que le sean asignados de acuerdo con su especialidad, o exonerarlo de su obligación de asistir al centro de trabajo. 
96.2 Las medidas cautelares se ejercitan durante el tiempo que dura el proceso administrativo disciplinario, siempre que ello no perjudique el derecho de defensa del servidor civil y se le abone la remuneración y demás derechos y beneficios que pudieran corresponderle. Excepcionalmente, cuando la falta presuntamente cometida por el servidor civil afecte gravemente los intereses generales, la medida cautelar puede imponerse de modo previo al inicio del procedimiento administrativo disciplinario. La validez de dicha medida está condicionada al inicio del procedimiento correspondiente.

96.3 Las medidas cautelares pueden ser modificadas o levantadas durante el curso del procedimiento administrativo disciplinario, de oficio o a instancia de parte, en virtud de circunstancias sobrevenidas o que no pudieron ser consideradas en el momento de su adopción.

96.4 Las medidas caducan de pleno derecho cuando se emite la resolución que pone fin al procedimiento administrativo disciplinario en la instancia que impuso la medida, cuando haya transcurrido el plazo fijado para su ejecución, o para la emisión de la resolución que pone fin al procedimiento.

Artículo 97. Medidas correctivas

La autoridad puede dictar medidas correctivas para revertir en lo posible el acto que causó el daño a la entidad pública o a los ciudadanos.

Artículo 98. Registro de sanciones

Las sanciones de suspensión y destitución deben ser inscritas en el Registro Nacional de Sanciones de Destitución y Despido creado por el artículo 242 de la Ley 27444, Ley del Procedimiento Administrativo General, que administra la Autoridad Nacional de Servicio Civil (Servir). La inscripción es permanente y debe indicar el plazo de la sanción.

\section{DISPOSICIONES COMPLEMENTARIAS FINALES}

PRIMERA. Trabajadores, servidores, obreros, entidades y carreras no comprendidos en la presente Ley

No están comprendidos en la presente Ley los trabajadores de las empresas del Estado, sin perjuicio de lo dispuesto en la tercera disposición complementaria final del Decreto Legislativo 1023, así como los servidores civiles del Banco Central de Reserva del Perú, el Congreso de la República, la Superintendencia Nacional de Aduanas y de Administración Tributaria, la Superintendencia de Banca, Seguros y AFP, y la Contraloría General de la República ni los servidores sujetos a carreras especiales. Tampoco se encuentran comprendidos los obreros de los gobiernos regionales y gobiernos locales. $(*)$

(*) Extremo declarado inconstitucional por el Literal a) del Resolutivo 1 del Pleno Jurisdiccional del Tribunal Constitucional Expedientes 0025-2013-PI-TC; 0003-2014-PI-TC; 0008-2014-PI-TC; 0017-2014-PI-TC, publicado el 04 mayo 2016.

Para los efectos del régimen del Servicio Civil se reconocen como carreras especiales las normadas por:

a) Ley 28091, Ley del Servicio Diplomático de la República.

b) Ley 23733, Ley universitaria. (*)

(*) Mediante Oficio $N^{\circ}$ 091-2016-SUNEDU-03, enviado por la Oficina de Secretaría General de la Superintendencia Nacional de Educación Superior Universitaria - SUNEDU, se indica que el presente inciso estaría derogado tácitamente por la Única Disposición Complementaria Derogatoria de la Ley $\mathrm{N}^{\circ} 30220$. (*) 
c) Ley 23536, Ley que establece las normas generales que regulan el trabajo y la carrera de los Profesionales de la Salud.

d) Ley 29944, Ley de Reforma Magisterial.

e) Ley 28359, Ley de Situación Militar de los Oficiales de las Fuerzas Armadas.

f) Decreto Legislativo 1149, Ley de la Carrera y Situación del personal de la Policía Nacional del Perú.

g) Ley 29709, Ley de la Carrera Especial Pública Penitenciaria.

h) Decreto Legislativo 052, Ley Orgánica del Ministerio Público.

i) Ley 29277, Ley de la Carrera Judicial.

Las carreras especiales, los trabajadores de empresas del Estado, los servidores sujetos a carreras especiales, los obreros de los gobiernos regionales y gobiernos locales, las personas designadas para ejercer una función pública determinada o un encargo específico, ya sea a dedicación exclusiva o parcial, remunerado o no, así como los servidores civiles del Banco Central de Reserva del Perú, el Congreso de la República, la Superintendencia Nacional de Aduanas y de Administración Tributaria, la Superintendencia de Banca, Seguros y AFP, y la Contraloría General de la República se rigen supletoriamente por el artículo III del Título Preliminar, referido a los Principios de la Ley del Servicio Civil; el Título II, referido a la Organización del Servicio Civil; y el Título V, referido al Régimen Disciplinario y Proceso Administrativo Sancionador, establecidos en la presente Ley. $(*)(* *)$

(*) Extremo declarado inconstitucional por el Literal a) del Resolutivo 1 del Pleno Jurisdiccional del Tribunal Constitucional Expedientes 0025-2013-PI-TC; 0003-2014-PI-TC; 0008-2014-PI-TC; 0017-2014-PI-TC, publicado el 04 mayo 2016.

(*) De conformidad con el Literal a) del Resolutivo 1 del Pleno Jurisdiccional del Tribunal Constitucional Expedientes 0025-2013-PI-TC; 0003-2014-PI-TC; 0008-2014-PI-TC; 00172014-PI-TC, publicado el 04 mayo 2016, se dispone que la presente disposición quede subsistente con el texto siguiente:

"PRIMERA. Trabajadores, servidores, obreros, entidades y carreras no comprendidos en la presente Ley. No están comprendidos en la presente Ley los trabajadores de las empresas del Estado, sin perjuicio de lo dispuesto en la tercera disposición complementaria final del Decreto Legislativo 1023, ni los servidores sujetos a carreras especiales.

Para los efectos del régimen del Servicio Civil se reconocen como carreras especiales las normadas por:

a) Ley 28091, Ley del Servicio Diplomático de la República.

b) Ley 23733 , Ley universitaria.

c) Ley 23536, Ley que establece las normas generales que regulan el trabajo y la carrera de los Profesionales de la Salud.

d) Ley 29944, Ley de Reforma Magisterial.

e) Ley 28359, Ley de Situación Militar de los Oficiales de las Fuerzas Armadas. 
f) Decreto Legislativo 1149, Ley de la Carrera y Situación del personal de la Policía Nacional del Perú.

g) Ley 29709, Ley de la Carrera Especial Pública Penitenciaria.

h) Decreto Legislativo 052, Ley Orgánica del Ministerio Público.

i) Ley 29277, Ley de la Carrera Judicial

Las carreras especiales, los trabajadores de empresas del Estado, los servidores sujetos a carreras especiales, las personas designadas para ejercer una función pública determinada o un encargo específico, ya sea a dedicación exclusiva o parcial, remunerado o no, se rigen supletoriamente por el artículo III del Título Preliminar, referido a los Principios de la Ley del Servicio Civil; el Título II, referido a la Organización del Servicio Civil; y el Título V, referido al Régimen Disciplinario y Proceso Administrativo Sancionador, establecidos en la presente Ley".

CONCORDANCIAS: D.S. $\mathrm{N}^{\circ}$ 040-2014-PCM, Art. 247 (Alcance del Servicio Civil de Carrera)

R.N ${ }^{\circ}$ 052-2016-SERVIR-PE, Primera Disp. Comp. Final (Entidades públicas y empresas del Estado fuera del ámbito del régimen de la Ley 30057)

SEGUNDA. Defensa y asesoría de los servidores civiles

Las entidades públicas deben otorgar la defensa y asesorías, a que se refiere el literal l) del artículo 35 de la presente Ley, a los servidores civiles que ejerzan o hayan ejercido funciones y resuelto actos administrativos o actos de administración interna bajo criterios de gestión en su oportunidad.

Para iniciar cualquier denuncia de carácter penal, la autoridad que conozca del caso debe solicitar un informe técnico jurídico emitido por la respectiva entidad en donde presta o prestó Servicio Civil el denunciado. Dicho informe sirve de sustento para efectos de la calificación del delito o archivo de la denuncia.

TERCERA. Derechos colectivos de quienes presten servicios al Estado bajo el régimen del Decreto Legislativo 728

Los derechos colectivos de quienes prestan servicios al Estado bajo el régimen del Decreto Legislativo 728 se interpretan de conformidad con las disposiciones del Convenio 151 de la Organización Internacional del Trabajo y consideran las Leyes de Presupuesto.

Esta disposición rige a partir del día siguiente de la publicación de la presente Ley.

CUARTA. Aprobación del cuadro de puestos de la entidad (CPE)

Créase el cuadro de puestos de la entidad (CPE) como instrumento de gestión. El CPE de cada entidad se aprueba mediante resolución del Consejo Directivo de Servir con opinión favorable de la Dirección General de Presupuesto Público del Ministerio de Economía y Finanzas. Este instrumento reemplaza al Cuadro de Asignación de Personal (CAP) y al Presupuesto Analítico de Personal (PAP).

CONCORDANCIAS: D.Leg. $\mathrm{N}^{\circ}$ 1153, Octava Disp. Comp. Final (Formulación de nuevos documentos de gestión)

QUINTA. Registro de la compensación por tiempo de servicios

Créase el Registro de la Compensación por Tiempo de Servicios (RCTS) a cargo del Ministerio de Economía y Finanzas, con la finalidad de centralizar la información para la liquidación de la compensación por tiempo de servicios y otras prestaciones del personal de los 
regímenes del Decreto Legislativo 728 y el Decreto Legislativo 276 que se trasladen al nuevo régimen.

SEXTA. Obligación de informar de las entidades

Los titulares de las entidades de la administración pública, incluidos los organismos constitucionalmente autónomos, las empresas públicas y los poderes del Estado, están obligados a remitir al Ministerio de Economía y Finanzas y a la Contraloría General de la Republica, dentro del primer trimestre del año, la información de los pagos realizados a su personal anualmente por toda fuente, desagregado por cada una de las personas que prestaron servicios durante el ejercicio fiscal anterior, bajo responsabilidad.

SÉTIMA. Aplicativo informático para el registro centralizado de planillas y de datos de los recursos humanos del sector público

Para fines de pago de las compensaciones, las entidades que se incorporen progresivamente a la presente Ley requieren que los datos personales de los beneficiarios y las planillas de pago se encuentren expresamente descritos y registrados mediante los procesos del "Aplicativo Informático para el Registro Centralizado de Planillas y de Datos de los Recursos Humanos del Sector Público - Aplicativo Informático" a cargo del Ministerio de Economía y Finanzas. Los datos registrados en el referido aplicativo sirven de base para las fases de formulación, programación, ejecución y evaluación del proceso presupuestario; para determinar el número de plazas del sector público; para implementar políticas salariales; para programar las obligaciones sociales y previsionales; y los gastos en personal cualquiera sea su modalidad de contratación directa o indirecta.

OCTAVA. Registro de títulos y grados obtenidos en el extranjero

Para efectos del funcionamiento del sistema administrativo de gestión de recursos humanos, tal como el ingreso, la progresión, cumplimiento de requisitos, entre otros, los títulos universitarios, grados académicos o estudios de posgrado emitidos por una universidad o entidad extranjera o los documentos que los acrediten son registrados ante Servir, requiriéndose como único acto previo la legalización del Ministerio de Relaciones Exteriores o el apostillado correspondiente. Servir administra este registro de manera transparente y con la finalidad de promover la capacitación y formación profesional de los funcionarios y servidores civiles. El registro es automático, gratuito y le otorga validez sólo para efectos del sistema administrativo de gestión de recursos humanos. Servir efectúa actos de fiscalización de la legalización del Ministerio de Relaciones Exteriores posterior sobre los documentos registrados, su falsedad origina la destitución del servidor civil sin perjuicio de las responsabilidades penales y administrativas. $(*)$

(*) De conformidad con la Quincuagésima Cuarta Disposición Complementaria Final de la Ley $\mathrm{N}^{\circ}$ 30114, publicada el 02 diciembre 2013, se dispone que la presente disposición, es de aplicación para todas las personas que prestan servicios en las entidades y empresas públicas, cualquiera sea su clasificación o régimen, incluyendo los directorios y consejos directivos, así como lo dispuesto en la Ley 29806, Ley que regula la contratación de personal altamente calificado en el Sector Público y dicta otras disposiciones.

(*) Mediante Oficio $N^{\circ}$ 091-2016-SUNEDU-03, enviado por la Oficina de Secretaría General de la Superintendencia Nacional de Educación Superior Universitaria - SUNEDU, se indica que la presente disposición estaría derogada tácitamente por la Única Disposición Complementaria Derogatoria de la Ley $\mathrm{N}^{\circ}$ 30220. (*)

NOVENA. Vigencia de la Ley

a) A partir del día siguiente de la publicación de la presente Ley, son de aplicación inmediata para los servidores civiles en los regímenes de los Decretos Legislativos 276 y 728 , las disposiciones sobre el artículo III del Título Preliminar, referido a los Principios de la Ley 
del Servicio Civil; el Título II, referido a la Organización del Servicio Civil; y el Capítulo VI del Título III, referido a los Derechos Colectivos.

Las normas de esta Ley sobre la capacitación y la evaluación del desempeño y el Título V, referido al Régimen Disciplinario y Procedimiento Sancionador, se aplican una vez que entren en vigencia las normas reglamentarias de dichas materias, con excepción de lo previsto en los artículos 17 y 18 de esta Ley, que se aplican una vez que se emita la resolución de inicio del proceso de implementación. Este dispositivo no afecta los programas de formación profesional y de formación laboral en curso.

b) La disposición complementaria final tercera, la disposición complementaria modificatoria segunda, la disposición complementaria transitoria sexta y el literal 1) del artículo 35 de la presente Ley rigen desde el día siguiente de la publicación de la presente Ley.

c) Las demás disposiciones de la presente Ley entran en vigencia al día siguiente de la publicación de los tres (3) reglamentos descritos en los literales a), b) y c) de la décima disposición complementaria final de la presente Ley.

d) Las disposiciones del Decreto Legislativo 276 y del Decreto Legislativo 728 y sus normas complementarias, reglamentarias y de desarrollo, con excepción de lo dispuesto en el literal a) de la novena disposición complementaria final de la presente Ley, son de exclusiva aplicación a los servidores comprendidos en dichos regímenes. En ningún caso constituyen fuente supletoria del régimen que la presente ley establece.

DÉCIMA. Disposiciones reglamentarias

En un plazo de ciento ochenta (180) días calendario se dictan las normas reglamentarias de la presente Ley, que se estructuran en, al menos, los siguientes reglamentos:

a) Reglamento general de la Ley del Servicio Civil, aprobado mediante decreto supremo, con el voto aprobatorio del Consejo de Ministros, a propuesta de Servir.

CONCORDANCIAS: D.S. N 040-2014-PCM (Reglamento General)

b) Reglamento de compensaciones, aprobado mediante decreto supremo refrendado por el Presidente del Consejo de Ministros y el Ministro de Economía y Finanzas. A propuesta de Servir para el caso de compensaciones no económicas; y a propuesta de la Dirección General de Gestión de Recursos Públicos, en coordinación con la Dirección General de Presupuesto Público, para el caso de compensaciones económicas.

CONCORDANCIAS: D.S. $\mathrm{N}^{\circ}$ 138-2014-EF (Reglamento de Compensaciones de la Ley $\mathrm{N}^{\circ}$ 30057, Ley del Servicio Civil)

c) Reglamento del régimen especial para gobiernos locales, aprobado mediante decreto supremo refrendado por el Presidente del Consejo de Ministros, a propuesta de Servir. (*)

CONCORDANCIAS: D.S. N 041-2014-PCM (Aprueban Reglamento del Régimen Especial para Gobiernos Locales)

(*) De conformidad con el Artículo Tercero de la Resolución $N^{\circ}$ 160-2013-SERVIR-PE, publicada el 02 octubre 2013, en tanto no se aprueben los Reglamentos señalados en la presente Disposición, las entidades facultativamente podrán aplicar las dos primeras etapas de los Lineamientos aprobados en el artículo primero de la citada Resolución.

UNDÉCIMA. Régimen especial para las municipalidades que cuentan hasta con 20 personas 
El personal de las municipalidades se rige por la presente Ley con excepción de aquellas que cuenten hasta con veinte (20) personas laborando para la entidad pública bajo cualquier régimen o modalidad de contratación. En dicho caso las municipalidades tienen un régimen especial adecuado a sus características y necesidades.

El régimen especial no puede asignar menos derechos que los contemplados en esta norma y procura la simplificación de los procedimientos de gestión del Servicio Civil.

La municipalidad incluida en el régimen especial cuenta con condiciones, requisitos, procedimientos y metodologías especiales, los cuales son desarrollados en las normas reglamentarias de la presente Ley.

DUODÉCIMA. Transparencia y compromiso con el ciudadano

Para el cumplimiento de la finalidad de la presente Ley, y en armonía con la debida cautela y eficiencia en la administración de los recursos públicos, todas las entidades del Estado se encuentran obligadas a publicar en su portal institucional o en cualquier medio que garantice su adecuada difusión, las metas institucionales, indicadores de desempeño y compromisos de mejora de los servicios y productos que suministran a los ciudadanos. Dichas metas, indicadores y compromisos deben redactarse en términos simples, para su adecuada comprensión, y deben ser cuantificables, a efectos de su evaluación y fiscalización.

Para el efecto, el Centro Nacional de Planeamiento Estratégico (CEPLAN) y Servir elaboran los instructivos necesarios.

La publicación y difusión de la información señalada debe efectuarse a más tardar el 31 de diciembre del año anterior al ejercicio presupuestal al que corresponden, priorizando la publicación de la información relacionada con las funciones de salud y educación.

\section{DISPOSICIONES COMPLEMENTARIAS TRANSITORIAS}

PRIMERA. Implementación progresiva de la Ley

La implementación del régimen previsto en la presente Ley se realiza progresivamente, y concluye en un plazo máximo de seis (6) años, conforme a las reglas de gradualidad que establecen las normas reglamentarias, en el marco de la programación de las leyes anuales de presupuesto.

La implementación del régimen previsto en esta Ley se realiza por entidades públicas, a partir de criterios de composición de los regímenes al interior de las entidades, naturaleza de las funciones de la entidad, nivel de gobierno, presupuesto y las prioridades del Estado.

La Presidencia Ejecutiva de Servir emite una resolución de "inicio de proceso de implementación" y otra de "culminación del proceso de implementación" del nuevo régimen en una entidad pública.

Corresponde también a la Presidencia Ejecutiva de Servir declarar la culminación del proceso de implementación del Régimen de la Ley del Servicio Civil en el sector público.

(*) De conformidad con la Décimo Novena Disposición Complementaria Final de la Ley $\mathrm{N}^{\circ}$ 30281, publicada el 04 diciembre 2014, se dispone que, para efectos de la implementación del Régimen de la Ley del Servicio Civil, lo establecido en los artículos 6 y 8 y en los numerales 9.1 y 9.4 del artículo 9 de la citada Ley no es aplicable a las entidades que cuenten con la resolución de "inicio del proceso de implementación" a que se refiere la presente disposición, y que cuenten con el Cuadro de Personal de la Entidad (CPE) aprobado; y que lo establecido en el segundo párrafo de la cuarta disposición complementaria transitoria de la presente Ley, no incluye a los planes de seguros médicos familiares u otros de naturaleza análoga, que estén 
percibiendo los trabajadores bajo los regímenes de los Decretos Legislativos 276, 728 y 1057. Para la aplicación de la exoneración al numeral 9.1 del artículo 9 a que se refiere la citada disposición se requiere el informe previo favorable de la Dirección General de Presupuesto Público del Ministerio de Economía y Finanzas. La referida disposición entra en vigencia a partir del 1 de enero de 2015.

SEGUNDA. Reglas de implementación

Las entidades públicas incluidas en el proceso de implementación se sujetan a las siguientes reglas:

a) Queda prohibida la incorporación de personas bajo los regímenes de los Decretos Legislativos 276 y 728, así como cualquier forma de progresión bajo dichos regímenes, salvo en los casos de funcionarios o cargos de confianza.

b) El régimen contemplado en el Decreto Legislativo 1057 es de aplicación hasta la culminación del proceso de implementación en cada entidad pública.

c) A partir de la resolución de "inicio del proceso de implementación", toda incorporación de servidores que se efectúe se sujeta a las disposiciones del régimen del Servicio Civil contenido en la presente Ley y sus disposiciones complementarias y reglamentarias.

d) Los destaques entre entidades públicas que no se encuentren en el nuevo régimen sólo puede realizarse hasta la emisión de la resolución de "inicio del proceso de implementación" de la entidad pública. No puede realizarse destaques desde y hacia dichas entidades con entidades públicas que hayan iniciado el proceso de implementación. Están permitidos los destaques entre entidades públicas que pertenezcan al régimen previsto en la presente Ley.

e) La regulación contenida en los Decretos Legislativos 276 y 728 no referida a principios y gestión del Servicio Civil, ética, incompatibilidades, prohibiciones y responsabilidades, capacitación y evaluación, mantiene su vigencia únicamente para los servidores comprendidos en dichos regímenes, que opten por mantenerse en ellos hasta cuando culminen su vínculo con la entidad.

Civil

TERCERA. Proceso de transición de las entidades públicas al régimen del Servicio

La presente Ley y su reglamento establecen las reglas, procesos y metodologías que deben seguir las entidades seleccionadas para el traspaso al régimen del Servicio Civil. Estas incluyen al menos los siguientes pasos:

a) Análisis situacional. Incluyendo un mapeo actual de puestos de la entidad, el análisis de los principales servicios a prestar por la entidad y de la carga de trabajo.

b) Propuesta de reorganización incluyendo la simplificación de procesos, definición de nuevos perfiles de puesto y la cantidad de personal necesario para ejercer sus funciones adecuadamente, realizada en coordinación con Servir.

c) Valorización de los puestos de la entidad pública en coordinación con Servir y el Ministerio de Economía y Finanzas.

CUARTA. Traslado de servidores bajo los regímenes de los Decretos Legislativos 276, 728 y 1057 al régimen del Servicio Civil

Los servidores bajo los regímenes de los Decretos Legislativos 276, 728 y 1057 pueden trasladarse voluntariamente y previo concurso público de méritos al régimen previsto en la presente Ley. Las normas reglamentarias establecen las condiciones con las que se realizan los 
concursos de traslado de régimen. La participación en los concursos para trasladarse al nuevo régimen no requiere de la renuncia previa al régimen de los Decretos Legislativos 276, 728 y 1057, según corresponda.

Los servidores bajo los regímenes de los Decretos Legislativos 276, 728 y 1057 que ganen los concursos y opten voluntariamente por el traslado al nuevo régimen previsto en la presente Ley, dejan de pertenecer a los regímenes señalados con la respectiva liquidación de sus beneficios sociales, según corresponda, y no tienen derecho a ninguna de las condiciones y beneficios establecidos en ellos; a partir de su traslado al nuevo régimen, cualquier disposición, resolución administrativa o judicial $(*)$ que contravenga esta disposición es nula de pleno derecho o inejecutable por el Sector Público.

Estos servidores no están sujetos al período de prueba previsto en la presente Ley.

Los servidores civiles que ingresan al régimen de Servicio Civil previsto en la presente Ley deben aportar al Sistema Privado de Pensiones o al Sistema Nacional de Pensiones, según corresponda. Los servidores civiles que han alcanzado el derecho a percibir una pensión pero optan por seguir prestando servicios, deben tramitar la suspensión de la pensión correspondiente.

(*) De conformidad con el Expediente $\mathrm{N}^{\circ}$ 00018-2013-PI-TC, publicado el 29 mayo 2014, se declara fundada en parte la demanda y, en consecuencia INCONSTITUCIONAL la expresión "o judicial" del segundo párrafo de la presente Disposición.

QUINTA. Gestión de servidores bajo diferentes regímenes en entidades públicas en el régimen del Servicio Civil

A fin de poder mejorar el funcionamiento de la entidad pública y únicamente adecuarla a la nueva organización y perfiles de puesto, las entidades públicas están autorizadas, desde el inicio de su proceso de implementación, a reubicar de puesto a quienes presten servicios en ella, incluso si pertenecen al régimen del Decreto Legislativo 276 o 728 o cualquier carrera o régimen especial.

El proceso de implementación de las entidades al régimen del Servicio Civil no configura la causal de terminación prevista en el inciso $\mathrm{k}$ del artículo 49 de la presente Ley. ${ }^{*}$ ) RECTIFICADO POR FE DE ERRATAS

\section{Civil}

SEXTA. Inaplicación de normas para las entidades que adopten el régimen del Servicio

A partir de la resolución de "inicio del proceso de implementación" emitida por Servir, no son de aplicación a las entidades públicas que implementen el régimen del Servicio Civil previsto en la presente Ley y a los puestos correspondientes a funcionarios públicos de libre designación y remoción: la Ley 28212, Ley que regula los ingresos de los Altos Funcionarios Autoridades del Estado y dicta otras medidas; y el Decreto de Urgencia 038-2006, que modifica la Ley 28212 y dicta otras medidas. En tales casos, las compensaciones se sujetan a lo dispuesto en la presente Ley y sus normas reglamentarias.

SÉTIMA. Servidores bajo el régimen del Decreto Legislativo 1057

Los servidores bajo el régimen del Decreto Legislativo 1057, Decreto Legislativo que regula el régimen especial de Contratación Administrativa de Servicios, pueden presentarse a los concursos para puestos que se convoquen bajo el nuevo régimen previsto en la presente Ley. En caso de obtener un puesto, para ser efectivamente incorporados al nuevo régimen deben haber renunciado al régimen anterior y a partir de su traslado al régimen del Servicio Civil no tienen derecho a ninguna de las condiciones ni beneficios establecidos en él.

OCTAVA. Implementación del régimen del Servicio Civil 
En tanto dure el proceso de implementación del régimen del Servicio Civil en todas las entidades públicas, las entidades públicas que hayan iniciado o culminado el proceso de implementación, pueden cubrir sus puestos en cualquier nivel de la carrera mediante concurso público de méritos abierto.

Lo dispuesto en los literales a) y d) del artículo 67 entra en vigencia cuando todas las entidades del Estado culminen el proceso de implementación del nuevo régimen previsto en la presente Ley.

\section{NOVENA. Ingreso de Directivos Públicos}

1. La entidad pública hasta la culminación del proceso de implementación del régimen del Servicio Civil previsto en la presente Ley, puede convocar a un proceso de selección de directivos públicos o cubrir los puestos directivos con:

a) El Cuerpo de Gerentes Públicos, creado por el Decreto Legislativo 1024, Decreto Legislativo que crea y regula el cuerpo de gerentes públicos.

b) El Fondo de Apoyo Gerencial, creado por el Decreto Ley 25650, Crean el Fondo de Apoyo Gerencial al Sector Público.

c) Los directivos superiores y ejecutivos considerados en los literales a) y b) del numeral 3 del artículo 4 de la Ley 28175, Ley Marco del Empleo Público.

d) El personal altamente calificado en el sector público normado por la Ley 29806, Ley que regula la contratación de personal altamente calificado en el sector público y dicta otras disposiciones.

e) Los egresados de la Escuela Nacional de Administración Pública ENAP, creada por Decreto Supremo 079-2012-PCM, Decreto Supremo que crea la Escuela Nacional de Administración Pública.

2. La entidad pública que se encuentre en proceso de implementación al régimen del Servicio Civil y que cuente con gerentes públicos seleccionados y asignados por Servir, pueden incorporarlos como directivos públicos bajo el régimen del Servicio Civil sin necesidad de concurso. Después de la culminación del proceso de implementación de la entidad todo directivo público debe ingresar por concurso público.

DÉCIMA. Aplicación del régimen sancionador y proceso administrativo disciplinario

A partir de la entrada en vigencia de la presente Ley, los procesos administrativos disciplinarios en las entidades públicas se tramitan de conformidad con lo estipulado en la presente Ley y sus normas reglamentarias. El Código de Ética de la Función Pública, Ley 27815 , se aplica en los supuestos no previstos en la presente norma.

Queda prohibida la aplicación simultánea del régimen disciplinario establecido en la presente Ley y la Ley del Código de Ética de la Función Pública o su Reglamento, para una misma conducta infractora, en el mismo procedimiento administrativo disciplinario.

El jefe de recursos humanos o quien hagas sus veces, también tramita los procedimientos por infracciones al Código de Ética de la Función Pública.

UNDÉCIMA. Trabajadores bajo el régimen del Decreto Ley 20530

A los servidores que se encuentren en el régimen pensionario del Decreto Ley 20530, Régimen de Pensiones y Compensaciones por Servicios Civiles prestados al Estado no comprendidos en el Decreto Ley 19990, que opten por incorporarse al régimen del Servicio 
Civil no se les acumula el tiempo de servicios, debiendo afiliarse al Sistema Nacional de Pensiones (SNP) o al Sistema Privado de Administración de Fondos de Pensiones (SPP), durante este nuevo período de trabajo.

Para el cálculo de la pensión a que se refiere el artículo 5 de la Ley 28449, Ley que establece las nuevas reglas del régimen de pensiones del Decreto Ley 20530, se toma como referencia la fecha de traslado al régimen del Servicio Civil.

Cuando dichos servidores culminen su Servicio Civil, percibirán la pensión bajo el régimen del Decreto Ley 20530, Régimen de Pensiones y Compensaciones por Servicios Civiles prestados al Estado no comprendidos en el Decreto Ley 19990, más aquella que pudiera haber generado en el SNP o SPP. ENAP

DUODÉCIMA. Destino de los egresados del Programa de Formación Amplia de la

Los egresados del Programa de Formación Amplia de la Escuela Nacional de Administración Pública pueden ser asignados, transitoriamente y en calidad de adjuntos, a las gerencias de entidades públicas en las que existan necesidades de modernización administrativa y que la entidad los requiera.

DÉCIMA TERCERA. Efectos del Programa de Formación Amplia en concursos públicos

Para efectos de los concursos públicos de personal, el Programa de Formación Amplia que se imparte en la Escuela Nacional de Administración Pública se considera equivalente a estudios de maestría.

DÉCIMA CUARTA. Efectos de implementación de la presente Ley

Para efectos de la implementación de la presente Ley, en lo que respecta a la compensación económica del puesto, el incremento de plazas y el ingreso de personal, las entidades que implementen la Ley del Servicio Civil quedan exoneradas de las restricciones previstas en los artículos 6 y 8 de la Ley 29951, Ley de Presupuesto del Sector Público para el Año Fiscal 2013, o los artículos que hagan sus veces en las posteriores leyes anuales de presupuesto.

\section{DISPOSICIONES COMPLEMENTARIAS MODIFICATORIAS}

PRIMERA. Descuentos autorizados a la planilla de pagos

Modifícase el literal c) de la Tercera Disposición Transitoria de la Ley 28411, Ley General del Sistema Nacional de Presupuesto, en los siguientes términos:

“(...)

c) La planilla única de pago sólo puede ser afectada por los descuentos establecidos por Ley o por mandato judicial expreso, de corresponder".

SEGUNDA. Aplicación del pago de la compensación por tiempo de servicios para el sector público.

Incorporase como tercer párrafo al artículo 2 del Decreto Legislativo 650, Ley de Compensación por Tiempo de Servicios, el siguiente texto:

"Cuando el empleador sea una entidad de la Administración Pública la compensación por tiempo de servicios que se devengue es pagada directamente por la entidad, dentro de las 48 horas de producido el cese y con efecto cancelatorio". $(*)$

(*) Confrontar con el Artículo Único de la Ley N³ 30408, publicada el 08 enero 2016. 


\section{DISPOSICIÓN COMPLEMENTARIA DEROGATORIA}

ÚNICA. Derogaciones Pública.

a) Derógase el artículo 13 de la Ley 27815, Ley del Código de Ética de la Función

b) Una vez que la presente Ley se implemente, el Decreto Legislativo 1025, que aprueba normas de capacitación y rendimiento para el sector público, y la Ley 28175, Ley Marco del Empleo Público, quedan derogados.

Comuníquese al señor Presidente Constitucional de la República para su promulgación.

En Lima, a los tres días del mes de julio de dos mil trece.

VÍCTOR ISLA ROJAS

Presidente del Congreso de la República

JUAN CARLOS EGUREN NEUENSCHWANDER

Segundo Vicepresidente del Congreso de la República

\section{AL SEÑOR PRESIDENTE CONSTITUCIONAL DE LA REPÚBLICA}

\section{POR TANTO:}

Mando se publique y cumpla.

Dado en la Casa de Gobierno, en Lima, a los tres días del mes de julio del año dos mil trece.

\section{OLLANTA HUMALA TASSO}

Presidente Constitucional de la República

JUAN F. JIMÉNEZ MAYOR

Presidente del Consejo de Ministros 


\title{
Anexo $\mathbf{N}^{\circ}$ 6: Texto único Ordenado del Decreto Ley 25593, Ley de Relaciones Colectivas de Trabajo DECRETO SUPREMO No 010-2003-TR
}

\author{
Aprueban Texto Único Ordenado de la Ley de Relaciones Colectivas de Trabajo
}

DECRETO SUPREMO No 010-2003-TR

(Consultado SPIG 31-07-2016)

CONCORDANCIAS: D.S. No 011-92-TR (REGLAMENTO)

OTRAS CONCORDANCIAS

\section{TEXTO ÚNICO ORDENADO DE LA LEY DE RELACIONES COLECTIVAS DE}

TÍTULO IE TRABAJO

DEL CAMPO DE APLICACIÓN

Artículo 1.- La presente norma se aplica a los trabajadores sujetos al régimen laboral de la actividad privada que prestan servicios para empleadores privados.

Los trabajadores de entidades del Estado y de empresas pertenecientes al ámbito de la Actividad Empresarial del Estado, sujetos al régimen de la actividad privada, quedan comprendidos en las normas contenidas en el presente Texto Único Ordenado en cuanto estas últimas no se opongan a normas específicas que limiten los beneficios en él previstos.

\section{TÍTULO II}

DE LA LIBERTAD SINDICAL

Artículo 2.- El Estado reconoce a los trabajadores el derecho a la sindicación, sin autorización previa, para el estudio, desarrollo, protección y defensa de sus derechos e intereses y el mejoramiento social, económico y moral de sus miembros.

Artículo 3.- La afiliación es libre y voluntaria. No puede condicionarse el empleo de un trabajador a la afiliación, no afiliación o desafiliación, obligársele a formar parte de un sindicato, ni impedírsele hacerlo.

Artículo 4.- El Estado, los empleadores y los representantes de uno y otros deberán abstenerse de toda clase de actos que tiendan a coactar, restringir o menoscabar, en cualquier forma, el derecho de sindicalización de los trabajadores, y de intervenir en modo alguno en la creación, administración o sostenimiento de las organizaciones sindicales que éstos constituyen.

Artículo 5.- Los sindicatos pueden ser:

a) De empresa, formados por trabajadores de diversas profesiones, oficios o especialidades, que presten servicios para un mismo empleador. 
b) De actividad, formados por trabajadores de profesiones, especialidades u oficios diversos de dos (2) o más empresas de la misma rama de actividad.

c) De gremio, formados por trabajadores de diversas empresas que desempeñan un mismo oficio, profesión o especialidad.

d) De oficios varios, formados por trabajadores de diversas profesiones, oficios o especialidades que trabajen en empresas diversas o de distinta actividad, cuando en determinado lugar, provincia o región el número de trabajadores no alcance el mínimo legal necesario para constituir sindicatos de otro tipo.

Artículo 6.- Las organizaciones de trabajadores no dependientes de una relación de trabajo se regirán por lo dispuesto en la presente norma, en lo que les sea aplicable.

Artículo 7.- Los sindicatos se pueden organizar con alcance local, regional o nacional. En tales casos, para el cumplimiento de sus fines al interior de la empresa, podrán constituir una "sección sindical".

Artículo 8.- Son fines y funciones de las organizaciones sindicales:

a) Representar el conjunto de trabajadores comprendidos dentro de su ámbito, en los conflictos, controversias o reclamaciones de naturaleza colectiva.

b) Celebrar convenciones colectivas de trabajo, exigir su cumplimiento y ejercer los derechos y acciones que de tales convenciones se originen.

c) Representar o defender a sus miembros en las controversias o reclamaciones de carácter individual, salvo que el trabajador accione directamente en forma voluntaria o por mandato de la ley, caso en el cual el sindicato podrá actuar en calidad de asesor.

d) Promover la creación y fomentar el desarrollo de cooperativas, cajas, fondos y, en general, organismos de auxilio y promoción social de sus miembros.

e) Promover el mejoramiento cultural, la educación general, técnica y gremial de sus miembros.

f) En general, todos los que no estén reñidos con sus fines esenciales ni con las leyes.

Artículo 9.- En materia de negociación colectiva, el sindicato que afilie a la mayoría absoluta de los trabajadores comprendidos dentro de su ámbito asume la representación de la totalidad de los mismos, aunque no se encuentren afiliados.

De existir varios sindicatos dentro de un mismo ámbito, podrán ejercer conjuntamente la representación de la totalidad de los trabajadores los sindicatos que afilien en conjunto a más de la mitad de ellos. 
En tal caso, los sindicatos determinarán la forma en que ejercerán esa representación, sea a prorrata, proporcional al número de afiliados, o encomendada a uno de los sindicatos. De no haber acuerdo, cada sindicato representa únicamente a sus afiliados.

\section{CONCORDANCIAS: D.S.N 006-2013-TR, Art. 7 (Representatividad)}

Artículo 10.- Son obligaciones de las organizaciones sindicales:

a) Observar estrictamente sus normas institucionales con sujeción a las leyes y normas que las regulan.

b) Llevar libros de actas, de registro de afiliación y de contabilidad debidamente sellados por la Autoridad de Trabajo.

c) Asentar en el libro de actas las correspondientes asambleas y sesiones de la junta directiva así como los acuerdos referentes a la misma y demás decisiones de interés general.

d) Comunicar a la Autoridad de Trabajo la reforma de sus estatutos, acompañando copia auténtica del nuevo texto y, asimismo a aquélla y al empleador, la nómina de junta directiva y los cambios que en ellas se produzcan dentro de los cinco (5) días hábiles siguientes.

e) Otorgar a sus dirigentes la credencial que los acredite como tales.

f) Las demás que señalen las leyes y normas que las regulan

Artículo 11.- Las organizaciones sindicales están impedidas de:

a) Dedicarse institucionalmente de manera exclusiva a asuntos de política partidaria, sin menoscabo de las libertades que la Constitución Política y los Convenios Internacionales de la OIT ratificados por el Perú les reconocen.

b) Coaccionar directa o indirectamente a los trabajadores a ingresar o retirarse de la organización sindical, salvo los casos de expulsión por causales previstas en el estatuto, debidamente comprobadas.

c) Aplicar fondos o bienes sociales a fines diversos de los que constituyen el objeto de la organización sindical o que no hayan sido debidamente autorizados en la forma prevista por la ley o por el estatuto.

d) Distribuir directa o indirectamente rentas o bienes del patrimonio sindical.

e) Realizar o estimular actividades contrarias a la ley o al orden público.

Artículo 12.- Para ser miembro de un sindicato se requiere:

a) Ser trabajador de la empresa, actividad, profesión u oficio que corresponda según el tipo de sindicato. 
b) No formar parte del personal de dirección o desempeñar cargo de confianza del empleador, salvo que el estatuto expresamente lo admita.

c) No estar afiliado a otro sindicato del mismo ámbito.

Los trabajadores podrán afiliarse a un sindicato durante el período de prueba, sin menoscabo de los derechos y obligaciones que durante dicho período les corresponde ejercer a las partes respecto a la relación laboral.

Artículo 13.- La calidad de miembros de un sindicato es inherente a la persona y no podrá ser transferida, transmitida ni delegada por ningún motivo.

Artículo 14.- Para constituirse y subsistir los sindicatos deberán afiliar por lo menos a veinte (20) trabajadores tratándose de sindicatos de empresa; o a cincuenta (50) trabajadores tratándose de sindicatos de otra naturaleza.

Artículo 15.- En las empresas cuyo número de trabajadores no alcance al requerido para constituir un sindicato, podrán elegir a dos (2) delegados que los representen ante su empleador y ante la Autoridad de Trabajo.

La elección de los delegados debe ser comunicada a la Autoridad de Trabajo y al empleador dentro de los cinco (5) días hábiles siguientes.

Artículo 16.- La constitución de un sindicato se hará en asamblea y en ella se aprobará el estatuto eligiéndose a la junta directiva, todo lo cual se hará constar en acta, refrendada por Notario Público o, a falta de éste, por el Juez de Paz de la localidad con indicación del lugar, fecha y nómina de asistentes.

Artículo 17.- El sindicato debe inscribirse en el registro correspondiente a cargo de la Autoridad de Trabajo. El registro es un acto formal, no constitutivo, y no puede ser denegado salvo cuando no se cumpla con los requisitos establecidos por la presente norma.

Artículo 18.- El registro de un sindicato le confiere personería gremial para los efectos previstos por la ley, así como para ser considerado en la conformación de organismos de carácter nacional e internacional.

Artículo 19.- Los sindicatos, cumplido el trámite de registro, podrán por este solo mérito inscribirse en el registro de asociaciones para efectos civiles.

Artículo 20.- La cancelación del registro por la Autoridad de Trabajo se efectuará sólo después de la disolución del sindicato, la misma que se producirá por las causales siguientes:

a) Por acuerdo de la mayoría absoluta de sus miembros.

b) Por cumplirse cualquiera de los eventos previstos en el estatuto para ese efecto.

c) Por pérdida de los requisitos constitutivos.

En los casos contemplados en los literales a) y b), la disolución se produce de pleno derecho y no requiere de declaración judicial previa. 
En el caso del literal c) la persona que acredite legítimo interés económico o moral solicitará al Juez de Trabajo competente la disolución del sindicato, el que previa verificación, resolverá la solicitud mediante el proceso sumarísimo en concordancia al literal e), numeral 3 del artículo 4 de la Ley No 26636 - Ley Procesal del Trabajo.

Por el solo mérito de la sentencia consentida o ejecutoriada que disponga la disolución del sindicato, se efectuará la cancelación del registro.

Artículo 21.- La asamblea es el órgano máximo del sindicato. En los sindicatos de empresa está constituida directamente por sus miembros. En los demás, así como en aquellos cuyos miembros laboran en localidades distintas, puede conformarse por intermedio de delegados cuyas facultades de decisión serán otorgadas de antemano o ratificadas posteriormente por las bases.

Los delegados deberán pertenecer a la unidad productiva que representan.

Artículo 22.- Son atribuciones de la asamblea general:

a) Elegir a la junta directiva.

b) Modificar el estatuto.

c) Acordar la fusión o absorción con otras organizaciones sindicales similares, o su disolución.

d) Acordar la afiliación o desafiliación a federaciones y confederaciones, y a organizaciones sindicales de nivel internacional.

e) Acordar la enajenación directa o indirecta de bienes del patrimonio sindical.

f) Decidir sobre la expulsión de cualquier afiliado o la imposición de sanciones disciplinarias.

g) Cualesquiera otras que señalen las normas legales o el estatuto.

Artículo 23.- La junta directiva tiene la representación legal del sindicato y estará constituida en la forma y con las atribuciones que determine el estatuto.

Artículo 24.- Para ser miembro de la junta directiva se requiere ser trabajador de la empresa. Este requisito no se exigirá para el caso de federaciones y confederaciones.

Artículo 25.- Todo miembro de un sindicato puede renunciar en cualquier momento, sin perjuicio de la obligación de pagar las cuotas vencidas y rendir cuentas si manejó fondos sindicales. La renuncia surte sus efectos, sin necesidad de aceptación, desde el momento en que es presentada. 
La renuncia debe ser comunicada al empleador dentro de los cinco (5) días hábiles de formulada.

Artículo 26.- El sindicato tiene autonomía para fijar en su estatuto la forma de separación temporal y expulsión de sus miembros. En este último caso, la decisión debe ser adoptada por la mayoría absoluta de sus miembros hábiles.

La expulsión deberá ser comunicada al empleador dentro de los cinco (5) días hábiles de efectuada.

Artículo 27.- El patrimonio del sindicato está constituido:

a) Por las cuotas de sus miembros y otras contribuciones obligatorias, cuyo monto y exigibilidad deben fijarse en el estatuto.

b) Por las contribuciones voluntarias de sus miembros o de terceros.

c) Por los demás bienes que adquiera a título gratuito u oneroso.

Artículo 28.- El empleador, a pedido del sindicato y con la autorización escrita del trabajador sindicalizado, está obligado a deducir de las remuneraciones las cuotas sindicales legales, ordinarias y extraordinarias, en este último caso, cuando sean comunes a todos los afiliados. Similar obligación rige respecto de aquellas contribuciones destinadas a la constitución y fomento de las cooperativas formadas por los trabajadores sindicalizados.

Artículo 29.- La retención de las cuotas sindicales a un trabajador cesará a partir del momento en que éste o el sindicato comunique por escrito al empleador la renuncia o expulsión.

Artículo 30.- El fuero sindical garantiza a determinados trabajadores no ser despedidos ni trasladados a otros establecimientos de la misma empresa, sin justa causa debidamente demostrada o sin su aceptación.

No es exigible el requisito de aceptación del trabajador cuando su traslado no le impida desempeñar el cargo de dirigente sindical.

Artículo 31.- Están amparados por el fuero sindical:

a) Los miembros de los sindicatos en formación, desde la presentación de la solicitud de registro y hasta tres (3) meses después.

b) Los miembros de la junta directiva de los sindicatos, federaciones y confederaciones, así como los delegados de las secciones sindicales. En el marco de la negociación colectiva se podrá ampliar el ámbito de protección del fuero sindical. -

El estatuto señalará qué cargos comprende la protección.

c) Los delegados a que se refiere el artículo 15 y los representantes a que se refiere el artículo 47 de la presente norma. 
d) Los candidatos a dirigentes o delegados, treinta (30) días calendario antes de la realización del proceso electoral y hasta treinta (30) días calendario después de concluido éste.

e) Los miembros de la comisión negociadora de un pliego petitorio, hasta tres (3) meses después de concluido el procedimiento respectivo.

Las partes podrán establecer en la convención colectiva el número de dirigentes amparados. A falta de acuerdo los dirigentes amparados en sindicatos de primer grado, no excederán de tres (3) dirigentes si el sindicato tiene hasta cincuenta (50) afiliados, agregándose un (1) dirigente por cada cincuenta (50) afiliados adicionales, hasta un máximo de doce (12) dirigentes. En las federaciones dos (2) dirigentes multiplicados por el número de sindicatos afiliados, no pudiendo sobrepasar en cualquier caso de quince (15) dirigentes ni comprender más de un (1) dirigente por empresa. En la Confederación hasta dos (2) dirigentes multiplicados por el número de federaciones afiliadas, no pudiendo sobrepasar en cualquier caso de veinte (20), ni comprender más de un (1) dirigente por empresa.

Mediante convención colectiva se podrá fijar un número mayor de dirigentes amparados por el fuero sindical.

No podrá establecerse ni modificarse el número de dirigentes amparados por el fuero sindical por acto o norma administrativa.

Artículo 32.- La convención colectiva contendrá las estipulaciones tendientes a facilitar las actividades sindicales en lo relativo a reuniones, comunicaciones, permisos y licencias.

A falta de convención, el empleador sólo está obligado a conceder permiso para la asistencia a actos de concurrencia obligatoria a los dirigentes que el Reglamento señale, hasta un límite de treinta (30) días naturales por año calendario, por dirigente; el exceso será considerado como licencia sin goce de remuneraciones y demás beneficios. Este límite no será aplicable cuando en el centro de trabajo exista costumbre o convenio colectivo más favorable.

El tiempo que dentro de la jornada ordinaria de trabajo abarquen los permisos y licencias remuneradas, destinados a facilitar las actividades sindicales se entenderán trabajados para todos los efectos legales hasta el límite establecido en la convención colectiva. No podrán otorgarse ni modificarse permisos ni licencias sindicales por acto o norma administrativa.

Artículo 33.- La disolución de un sindicato se produce por fusión o absorción; por acuerdo de la mayoría absoluta de sus miembros adoptados en asamblea general o fuera de ella, acreditado con las correspondientes firmas; por cumplirse cualesquiera de los eventos previstos en el estatuto para este efecto; o por resolución en última instancia de la Corte Suprema. En este último caso, las causales serán las señaladas para una asociación y el procedimiento será el establecido por el artículo 96 del Código Civil.

Igualmente, puede solicitar la disolución la parte que acredite tener legítimo interés económico o moral, en cuyo caso podrá requerir al Ministerio Público para que solicite ante el Poder Judicial la disolución del sindicato, siguiendo el trámite previsto en el artículo 96 del Código Civil, en lo que fuere aplicable. Por el sólo mérito de la sentencia consentida o 
ejecutoriada que disponga la disolución del sindicato, la Autoridad de Trabajo efectuará la cancelación del registro sindical.

Tratándose de un sindicato de empresa, la disolución se producirá, además, por liquidación de la empresa a que pertenece. En este caso la disolución opera de pleno derecho.

Artículo 34.- El patrimonio sindical que quedare, una vez realizados los activos y pagados los pasivos, será adjudicado por el liquidador a la organización sindical que el estatuto o la asamblea general designe para tal efecto. A falta de tal designación se adjudicará a la Beneficencia Pública del domicilio del sindicato o a una institución u organización de utilidad social oficialmente reconocida.

Artículo 35.- Los sindicatos de base podrán constituir o integrar organismos de grado superior, sin que pueda impedirse u obstaculizarse tal derecho.

Artículo 36.- Para constituir una federación se requiere la unión de no menos de dos (2) sindicatos registrados de la misma actividad o clase.

Para constituir una confederación se requiere la unión de no menos de dos (2) federaciones registradas.

Artículo 37.- Los sindicatos y federaciones podrán retirarse de las respectivas organizaciones de grado superior en cualquier momento, aunque exista pacto en contrario.

Artículo 38.- Las federaciones y confederaciones se rigen por todo lo dispuesto para los sindicatos, en lo que les sea aplicable.

Artículo 39.- La cancelación del registro, la disolución o la liquidación de una federación o confederación no afecta la subsistencia de las organizaciones de grado inferior que la conforman.

Artículo 40.- Para la constitución de sindicatos de empleadores se requiere de un mínimo de cinco (5) de la misma actividad, igual número de sindicatos para constituir una federación, y de federaciones para una confederación.

Se les aplican las normas del presente Texto Único Ordenado, en lo que fuere pertinente.

\section{TÍTULO III}

\section{DE LA NEGOCIACIÓN COLECTIVA}

Artículo 41.- Convención colectiva de trabajo es el acuerdo destinado a regular las remuneraciones, las condiciones de trabajo y productividad y demás, concernientes a las relaciones entre trabajadores y empleadores, celebrado, de una parte, por una o varias organizaciones sindicales de trabajadores o, en ausencia de éstas, por representantes de los trabajadores interesados, expresamente elegidos y autorizados y, de la otra, por un empleador, un grupo de empleadores, o varias organizaciones de empleadores. 
Sólo estarán obligadas a negociar colectivamente las empresas que hubieren cumplido por lo menos un (1) año de funcionamiento.

Artículo 42.- La convención colectiva de trabajo tiene fuerza vinculante para las partes que la adoptaron. Obliga a éstas, a las personas en cuyo nombre se celebró y a quienes les sea aplicable, así como a los trabajadores que se incorporen con posterioridad a las empresas comprendidas en la misma, con excepción de quienes ocupan puestos de dirección o desempeñan cargos de confianza.

Artículo 43.- La convención colectiva de trabajo tiene las características siguientes:

a) Modifica de pleno derecho los aspectos de la relación de trabajo sobre los que incide. Los contratos individuales quedan automáticamente adaptados a aquella y no podrán contener disposiciones contrarias en perjuicio del trabajador.

b) Rige desde el día siguiente al de caducidad de la convención anterior; o, si no la hubiera, desde la fecha de presentación del pliego, excepto las estipulaciones para las que señale plazo distinto que consistan en obligaciones de hacer o de dar en especie, que regirán desde la fecha de su suscripción.

c) Rige durante el período que acuerden las partes. A falta de acuerdo, su duración es de un (1) año.

d) Continúa rigiendo mientras no sea modificada por una convención colectiva posterior, sin perjuicio de aquellas cláusulas que hubieren sido pactadas con carácter permanente o cuando las partes acuerden expresamente su renovación o prórroga total o parcial.

e) Continúa en vigencia, hasta el vencimiento de su plazo, en caso de fusión, traspaso, venta, cambio de giro del negocio y otras situaciones similares.

f) Debe formalizarse por escrito en tres (3) ejemplares, uno para cada parte y el tercero para su presentación a la Autoridad de Trabajo con el objeto de su registro y archivo.

Artículo 44.- La convención colectiva tendrá aplicación dentro del ámbito que las partes acuerden, que podrá ser:

a) De la empresa, cuando se aplique a todos los trabajadores de una empresa, o a los de una categoría, sección o establecimiento determinado de aquella.

b) De una rama de actividad, cuando comprenda a todos los trabajadores de una misma actividad económica, o a parte determinada de ella.

c) De un gremio, cuando se aplique a todos los trabajadores que desempeñen una misma profesión, oficio o especialidad en distintas empresas.

Artículo 45.- Si no existe previamente una convención colectiva en cualquier nivel de los señalados en el artículo anterior, las partes decidirán, de común acuerdo, el nivel en que 
entablarán la primera convención. A falta de acuerdo, la negociación se llevará a nivel de empresa.

De existir convención en algún nivel, para entablar otra en un nivel distinto, con carácter sustitutorio o complementario, es requisito indispensable el acuerdo de partes, no pudiendo establecerse por acto administrativo ni por laudo arbitral.

Las convenciones de distinto nivel acordadas por las partes deberán articularse para definir las materias que serán tratadas en cada una. En caso de conflicto se aplicará la convención más favorable, confrontadas en su integridad.

Podrán negociarse a nivel de empresa las materias no tratadas en una convención a nivel superior, que la reglamenten o que se refieran a condiciones de trabajo propias y exclusivas de la empresa.

Artículo 46.- Para que el producto de una negociación colectiva por rama de actividad o gremio tenga efectos generales para todos los trabajadores del ámbito, se requiere que la organización sindical u organizaciones sindicales representen a la mayoría de las empresas y trabajadores de la actividad o gremio respectivo, en el ámbito local, regional o nacional, y que sean convocadas, directa o indirectamente, todas las empresas respectivas.

En caso no se cumplan los requisitos de mayoría señalados en el párrafo anterior, el producto de la negociación colectiva, sea convenio o laudo arbitral, o excepcional por resolución administrativa, tiene una eficacia limitada a los trabajadores afiliados a la organización u organizaciones sindicales correspondientes. De existir un nivel de negociación en determinada rama de actividad ésta mantendrá su vigencia.

Artículo 47.- Tendrán capacidad para negociar colectivamente en representación de los trabajadores:

a) En las convenciones colectivas de empresa, el sindicato respectivo o, a falta de este, los representantes expresamente elegidos por la mayoría absoluta de trabajadores.

b) En las convenciones por rama de actividad o gremio, la organización sindical o conjunto de ellas de la rama o gremio correspondiente.

La representación de los trabajadores en todo ámbito de negociación estará a cargo de una comisión constituida por no menos de tres (3) ni más de doce (12) miembros plenos, cuyo número se regulará en atención al ámbito de aplicación de la convención y en proporción al número de trabajadores comprendidos. En los casos que corresponda, la comisión incluye a los dos (2) delegados previstos por el artículo 15 de la presente norma.

Artículo 48.- La representación de los empleadores estará a cargo:

a) En las convenciones de empresa, del propio empresario o las personas que él designe. 
b) En las convenciones por rama de actividad o de gremio, de la organización representativa de los empleadores en la respectiva actividad económica y, de no existir ésta, de los representantes de los empleadores comprendidos.

La comisión designada por los empleadores no podrá ser superior en número a la que corresponde a los trabajadores.

Artículo 49.- La designación de los representantes de los trabajadores constará en el pliego que presenten conforme al artículo 51; la de los empleadores, en cualquiera de las formas admitidas para el otorgamiento de poderes.

En ambos casos deberán estipularse expresamente las facultades de participar en la negociación y conciliación, practicar todos los actos procesales propios de éstas, suscribir cualquier acuerdo y llegado el caso, la convención colectiva de trabajo. No es admisible la impugnación de un acuerdo por exceso en el uso de las atribuciones otorgadas, salvo que se demuestre la mala fe.

Todos los miembros de la comisión gozan del amparo reconocido por las disposiciones legales vigentes a los dirigentes sindicales, desde el inicio de la negociación y hasta tres meses (3) de concluida ésta.

Artículo 50.- Las partes podrán ser asesoradas en cualquier etapa del proceso por abogados y otros profesionales debidamente colegiados, así como por dirigentes de organizaciones de nivel superior a las que se encuentren afiliadas.

Los asesores deberán limitar su intervención a la esfera de su actividad profesional y en ningún caso sustituir a las partes en la negociación ni en la toma de decisiones.

Artículo 51.- La negociación colectiva se inicia con la presentación de un pliego que debe contener un proyecto de convención colectiva, con lo siguiente:

a) Denominación y número de registro del o de los sindicatos que lo suscriben, y domicilio único que señalen para efectos de las notificaciones.

De no existir sindicato, las indicaciones que permitan identificar a la coalición de trabajadores que lo presenta.

b) La nómina de los integrantes de la comisión negociadora con los requisitos establecidos por el artículo 49.

c) Nombre o denominación social y domicilio de cada una de las empresas u organizaciones de empleadores comprendidas.

d) Las peticiones que se formulan sobre remuneraciones, condiciones de trabajo y productividad y demás que se planteen, las que deberán tener forma de cláusula e integrarse armónicamente dentro de un solo proyecto de convención. 
e) Firma de los dirigentes sindicales designados para tal fin por la asamblea, o de los representantes acreditados, de no haber sindicato.

Artículo 52.- El pliego debe ser presentado no antes de sesenta (60) ni después de treinta (30) días calendario anteriores a la fecha de caducidad de la convención vigente. En caso de presentación posterior al plazo señalado, la vigencia a que se refiere el inciso b) del artículo 43 será postergada en forma directamente proporcional al retardo.

Artículo 53.- El pliego se presenta directamente a la empresa, remitiéndose copia del mismo a la Autoridad de Trabajo.

En caso de que aquella se negara a recibirlo, la entrega se hará a través de la Autoridad de Trabajo, teniéndose como fecha de presentación la de ingreso por mesa de partes.

En las convenciones por rama de actividad o gremio, la entrega se hará siempre por intermedio de la Autoridad de Trabajo.

Artículo 54.- Es obligatoria la recepción del pliego, salvo causa legal o convencional objetivamente demostrable.

Las partes están obligadas a negociar de buena fe y a abstenerse de toda acción que pueda resultar lesiva a la contraria, sin menoscabo del derecho de huelga legítimamente ejercitado.

Artículo 55.- A petición de los representantes de los trabajadores, los empleadores deberán proporcionar la información necesaria sobre la situación económica, financiera, social y demás pertinente de la empresa, en la medida en que la entrega de tal información no sea perjudicial para ésta.

La información que ha de proporcionarse será determinada de común acuerdo entre las partes. De no haber acuerdo, la Autoridad de Trabajo precisará la información básica que deba ser facilitada para el mejor resultado de las negociaciones.

Los trabajadores, sus representantes y asesores deberán guardar reserva absoluta sobre la información recibida, bajo apercibimiento de suspensión del derecho de información, sin perjuicio de las medidas disciplinarias y acciones legales a que hubiere lugar.

Artículo 56.- En el curso del procedimiento, a petición de una de las partes o de oficio, el Ministerio de Trabajo y Promoción del Empleo, a través de una oficina especializada, practicará la valorización de las peticiones de los trabajadores y examinará la situación económico - financiera de las empresas y su capacidad para atender dichas peticiones, teniendo en cuenta los niveles existentes en empresas similares, en la misma actividad económica o en la misma región.

Asimismo estudiará, en general, los hechos y circunstancias implícitos en la negociación. 
La Oficina especializada podrá contar con el asesoramiento del Ministerio de Economía y Finanzas, la Comisión Nacional Supervisora de Empresas y Valores (CONASEV) y de otras instituciones cuando la naturaleza o importancia del caso lo requiera.

El dictamen correspondiente, debidamente fundamentado y emitido sobre la base de la documentación que obligatoriamente presentarán las empresas y de las investigaciones que se practiquen será puesto en conocimiento de las partes para que puedan formular su observación.

Artículo 57.- La negociación colectiva se realizará en los plazos y oportunidades que las partes acuerden, dentro o fuera de la jornada laboral, y debe iniciarse dentro de los diez (10) días calendario de presentado el pliego.

El empleador o empleadores podrán proponer cláusulas nuevas o sustitutorias de las establecidas en convenciones anteriores.

Sólo es obligatorio levantar actas para consignar los acuerdos adoptados en cada reunión, siendo facultad de las partes dejar constancia de los pedidos u ofertas por ellas formulados.

Artículo 58.- Las partes informarán a la Autoridad de Trabajo de la terminación de la negociación, pudiendo simultáneamente solicitar el inicio de un procedimiento de conciliación.

Si ninguna de las partes lo solicitara, la Autoridad de Trabajo podrá iniciar dicho procedimiento de oficio, si lo estimare necesario o conveniente, en atención a las características del caso.

Artículo 59.- La función conciliatoria estará a cargo de un cuerpo técnico especializado y calificado del Ministerio de Trabajo y Promoción del Empleo, pudiendo las partes, sin embargo, si así lo acuerdan, encomendársela a personas privadas, caso en el cual deberán remitir a la Autoridad de Trabajo copia de las actas que se levanten.

En uno y otro caso, el procedimiento de conciliación deberá caracterizarse por la flexibilidad y la simplicidad en su desarrollo, debiendo el conciliador desempeñar un papel activo en la promoción del avenimiento entre las partes. Si éstas lo autorizan, el conciliador podrá actuar como mediador, a cuyo efecto, en el momento que lo considere oportuno, presentará una o más propuestas de solución que las partes pueden aceptar o rechazar.

Se realizarán tantas reuniones de conciliación como sean necesarias.

Artículo 60.- Las partes conservan en el curso de todo el procedimiento el derecho de reunirse, por propia iniciativa, o a indicación de la Autoridad de Trabajo, y de acordar lo que estimen adecuado. Asimismo, podrán recurrir a cualquier medio válido para la solución pacífica de la controversia.

Artículo 61.- Si no se hubiese llegado a un acuerdo en negociación directa o en conciliación, de haberla solicitado los trabajadores, podrán las partes someter el diferendo a arbitraje. 
CONCORDANCIAS: R.M. No 076-2012-TR (Aprueban Directiva General "Lineamientos para la intervención administrativa en conflictos laborales colectivos:

los llamados "extraproceso", la preferencia por el arbitraje potestativo y la intervención resolutoria como facultad excepcional")

Artículo 62.- En el caso del artículo anterior, los trabajadores pueden alternativamente, declarar la huelga conforme a las reglas del artículo 73. Durante el desarrollo de la huelga, las partes o la Autoridad de Trabajo podrán designar un mediador.

La propuesta final que éste formule deberá ponerse en conocimiento de las partes.

Las fórmulas de mediación, en caso de no ser aceptadas por las partes, no comprometerán las decisiones arbitrales ulteriores.

Artículo 63.- Durante el desarrollo de la huelga los trabajadores podrán, asimismo, proponer el sometimiento del diferendo a arbitraje, en cuyo caso se requerirá de la aceptación del empleador.

Artículo 64.- El arbitraje puede estar a cargo de un árbitro unipersonal, un tribunal ad hoc, una institución representativa, la propia Autoridad de Trabajo, o cualquier otra modalidad que las partes específicamente acuerden, lo que constará en el acta de compromiso arbitral. Si no hubiere acuerdo sobre el órgano arbitral se constituirá de oficio un tribunal tripartito integrado por un árbitro que deberá designar cada parte y un presidente designado por ambos árbitros o, a falta de acuerdo, por la Autoridad de Trabajo.

En ningún caso podrán ser árbitros los abogados, asesores, representantes, apoderados o, en general, las personas que tengan relación con las partes o interés, directo o indirecto, en el resultado.

Las normas procesales serán idénticas para toda forma de arbitraje y estarán regidas por los principios de oralidad, sencillez, celeridad, inmediación y lealtad.

Si el empleador es una empresa comprendida en el ámbito de la Actividad Empresarial del Estado, o se trata de una entidad del Estado cuyos trabajadores se encuentran sujetos al régimen laboral de la actividad privada, el Reglamento de la presente norma establecerá la forma en que se designará, a falta de acuerdo entre las partes, al presidente del tribunal arbitral. En ningún caso podrá recaer tal designación en la Autoridad de Trabajo.

Artículo 65.- El laudo no podrá establecer una solución distinta a las propuestas finales de las partes ni combinar planteamientos de una y otra.

El laudo recogerá en su integridad la propuesta final de una de las partes. Sin embargo, por su naturaleza de fallo de equidad, podrá atenuar posiciones extremas.

Para la decisión deberán tenerse presente las conclusiones del dictamen a que se refiere el artículo 56. 
Artículo 66.- El laudo, cualquiera sea la modalidad del órgano arbitral, es inapelable y tiene carácter imperativo para ambas partes.

Es susceptible de impugnación ante la Sala Laboral de la Corte Superior, en los casos siguientes:

a) Por razón de nulidad.

b) Por establecer menores derechos a los contemplados por la ley en favor de los trabajadores.

La interposición de la acción impugnatoria no impide ni posterga la ejecución del laudo arbitral, salvo resolución contraria de la autoridad judicial competente.

Artículo 67.- Derogado por el artículo 4 de la Ley No 27912.

Artículo 68.- Cuando una huelga se prolongue excesivamente en el tiempo, comprometiendo gravemente a una empresa o sector productivo, o derive en actos de violencia, o de cualquier manera, asuma características graves por su magnitud o consecuencias, la autoridad administrativa promoverá el arreglo directo u otras formas de solución pacífica del conflicto. De fracasar ésta, el Ministerio de Trabajo y Promoción del Empleo resolverá en forma definitiva. (1)(2)

(1) De conformidad con el Artículo 3 del Decreto Supremo No 014-2011-TR, publicado el 17 septiembre 2011, la referencia al Ministerio de Trabajo y Promoción del Empleo, establecida en el presente artículo, debe interpretarse como competencia de las direcciones regionales de trabajo y promoción del Empleo, con la excepción transitoria de la jurisdicción de Lima Metropolitana. No obstante ello, cuando los supuestos establecidos en el presente artículo tengan un efecto o dimensión supra regional o nacional, la competencia resolutiva recae, de forma exclusiva y excluyente, en la Dirección General de Trabajo del Ministerio de Trabajo y Promoción del Empleo.

(2) De conformidad con el Artículo 4 del Decreto Supremo No 014-2011-TR, publicado el 17 septiembre 2011, las resoluciones administrativas, de primera y segunda instancia, que se expiden al amparo del presente artículo tienen la naturaleza de laudo arbitral, siéndoles aplicables los artículos 65 y 66 de la presente norma.

CONCORDANCIAS: R.M. No 076-2012-TR (Aprueban Directiva General "Lineamientos para la intervención administrativa en conflictos laborales colectivos:

los llamados "extraproceso", la preferencia por el arbitraje potestativo y la intervención resolutoria como facultad excepcional")

D.S. $\mathrm{N}^{\circ}$ 017-2012-TR (Determinan dependencias que tramitarán y resolverán las solicitudes y reclamaciones que se inicien ante las Autoridades Administrativas de Trabajo)

Artículo 69.- Es causal válida para la suspensión de la negociación en cualquiera de sus etapas, e impedimento para el arbitraje, la realización de los actos señalados en el artículo 81 o el uso de violencia sobre personas o cosas. Adolece de nulidad insalvable el acuerdo de partes o el laudo, celebrado o dictado, según el caso, bajo presión derivada de tales hechos. 
Artículo 70.- Los acuerdos adoptados en conciliación o mediación, los laudos arbitrales y las resoluciones de la Autoridad de Trabajo tienen la misma naturaleza y surten idénticos efectos que las convenciones adoptadas en negociación directa.

Artículo 71.- Quedan reguladas por la presente norma, en lo que les resulte aplicable las negociaciones que se realizan a través de comisiones paritarias, multipartitas y demás casos especiales.

\section{TÍTULO IV}

\section{DE LA HUELGA}

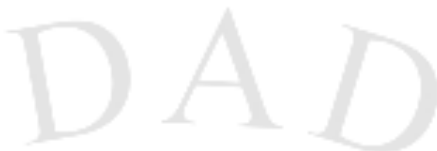

Artículo 72.- Huelga es la suspensión colectiva del trabajo acordada mayoritariamente y realizada en forma voluntaria y pacífica por los trabajadores, con abandono del centro de trabajo. Su ejercicio se regula por el presente Texto Único Ordenado y demás normas complementarias y conexas.

Artículo 73.- Para la declaración de huelga se requiere:

a) Que tenga por objeto la defensa de los derechos e intereses socioeconómicos o profesionales de los trabajadores en ella comprendidos.

b) Que la decisión sea adoptada en la forma que expresamente determinen los estatutos y que en todo caso representen la voluntad mayoritaria de los trabajadores comprendidos en su ámbito.

El acta de asamblea deberá ser refrendada por Notario Público o, a falta de éste, por el Juez de Paz de la localidad.

Tratándose de sindicatos de actividad o gremio cuya asamblea esté conformada por delegados, la decisión será adoptada en asamblea convocada expresamente y ratificada por las bases.

c) Que sea comunicada al empleador y a la Autoridad de Trabajo, por lo menos con cinco (5) días útiles de antelación o con diez (10) tratándose de servicios públicos esenciales, acompañando copia del acta de votación.

d) Que la negociación colectiva no haya sido sometida a arbitraje.

Artículo 74.- Dentro de los tres (3) días útiles de recibida la comunicación, la Autoridad de Trabajo deberá pronunciarse por su improcedencia si no cumple con los requisitos del artículo anterior.

La resolución es apelable dentro del tercer día de notificada a la parte. La resolución de segunda instancia deberá ser pronunciada dentro de los dos (2) días siguientes, bajo responsabilidad. 
Artículo 75.- El ejercicio del derecho de huelga supone haber agotado previamente la negociación directa entre las partes respecto de la materia controvertida.

Artículo 76.- La huelga puede comprender a una empresa, a uno o a varios de sus establecimientos, a una rama de actividad o a un gremio, y ser declarada por un tiempo determinado o indefinido; si no se indica previamente su duración, se entenderá que se declara por tiempo indefinido.

Artículo 77.- La huelga declarada observando lo establecido en el artículo 73, produce los siguientes efectos:

a) Determina la abstención total de las actividades de los trabajadores en ella comprendidos, con excepción del personal de dirección o de confianza y del personal comprendido en el artículo 78 .

b) Suspende todos los efectos de los contratos individuales de trabajo, inclusive la obligación de abonar la remuneración, sin afectar la subsistencia del vínculo laboral.

c) Impide retirar del centro de trabajo las maquinarias, materias primas u otros bienes, salvo circunstancias excepcionales con conocimiento previo de la Autoridad de Trabajo.

d) No afecta la acumulación de antigüedad para efectos de la compensación por tiempo de servicios.

Artículo 78.- Se exceptúa de la suspensión de actividades a aquellas labores indispensables para la empresa cuya paralización ponga en peligro a las personas, la seguridad o la conservación de los bienes o impida la reanudación inmediata de la actividad ordinaria de la empresa una vez concluida la huelga.

Artículo 79.- La huelga debe desarrollarse necesariamente en forma pacífica, sin recurrir a ningún tipo de violencia sobre personas o bienes.

Artículo 80.- Cuando lo solicite por lo menos la quinta parte de los trabajadores afectados, la continuación de la huelga requerirá de ratificación.

La consulta se sujetará a los mismos requisitos que la declaratoria de huelga.

Artículo 81.- No están amparadas por la presente norma las modalidades irregulares, tales como paralización intempestiva, paralización de zonas o secciones neurálgicas de la empresa, trabajo a desgano, a ritmo lento o a reglamento, reducción deliberada del rendimiento o cualquier paralización en la que los trabajadores permanezcan en el centro de trabajo y la obstrucción del ingreso al centro de trabajo.

Artículo 82.- Cuando la huelga afecte los servicios públicos esenciales o se requiera garantizar el cumplimiento de actividades indispensables, los trabajadores en conflicto deben garantizar la permanencia del personal necesario para impedir su interrupción total y asegurar la continuidad de los servicios y actividades que así lo exijan. 
Anualmente y durante el primer trimestre, las empresas que prestan estos servicios esenciales, comunicarán a sus trabajadores u organizaciones sindicales que los representan y a la Autoridad de Trabajo, el número y ocupación de los trabajadores necesarios para el mantenimiento de los servicios, los horarios y turnos que deben cumplir, así como la periodicidad en que deben producirse los respectivos reemplazos. La indicada comunicación tiene por objeto que los trabajadores u organización sindical que los represente cumpla con proporcionar la nómina respectiva cuando se produzca la huelga. Los trabajadores que sin causa justificada dejen de cumplir el servicio, serán sancionados de acuerdo a Ley. Los casos de divergencia sobre el número y ocupación de los trabajadores que deben figurar en la relación señalada en este artículo, serán resueltos por la Autoridad de Trabajo.

Artículo 83.- Son servicios públicos esenciales:

a) Los sanitarios y de salubridad.

CONCORDANCIAS: R.M. No 579-2008-MINSA (Establecen servicios y actividades públicos esenciales en los Establecimientos de Salud en el ámbito nacional)

b) Los de limpieza y saneamiento.

c) Los de electricidad, agua y desagüe, gas y combustible.

d) Los de sepelio, y los de inhumaciones y necropsias.

e) Los de establecimientos penales.

f) Los de comunicaciones y telecomunicaciones.

g) Los de transporte.

h) Los de naturaleza estratégica o que se vinculen con la defensa o seguridad nacional.

i) Los de administración de justicia por declaración de la Corte Suprema de Justicia de la República.

j) Otros que sean determinados por Ley.

CONCORDANCIAS: D.S. N 040-2014-PCM, Art. 84 (De los servicios esenciales)

Artículo 84.- La huelga será declarada ilegal:

a) Si se materializa no obstante haber sido declarada improcedente.

b) Por haberse producido, con ocasión de ella, violencia sobre bienes o personas.

c) Por incurrirse en alguna de las modalidades previstas en el artículo 81.

d) Por no cumplir los trabajadores con lo dispuesto en el artículo 78 o en el artículo 82.

e) Por no ser levantada después de notificado el laudo o resolución definitiva que ponga término a la controversia.

La resolución será emitida, de oficio o a pedido de parte, dentro de los dos (2) días de producidos los hechos y podrá ser apelada. La resolución de segunda instancia deberá ser emitida dentro del plazo máximo de dos (2) días.

Artículo 85.- La huelga termina:

a) Por acuerdo de las partes en conflicto.

b) Por decisión de los trabajadores.

c) Por resolución suprema en el caso previsto en el artículo 68

d) Por ser declarada ilegal. 
Artículo 86.- La huelga de los trabajadores sujetos al régimen laboral público, se sujetará a las normas contenidas en el presente Título en cuanto le sean aplicables.

La declaración de ilegalidad de la huelga será efectuada por el Sector correspondiente.

TÍTULO V

DISPOSICIONES TRANSITORIAS Y FINALES

Primera.- Cuando en la presente norma se haga mención a empresa, se tendrá para todo efecto como referido a empleador, cualquiera sea su forma jurídica, modalidad, fines, etc.

Segunda.- De conformidad con el artículo I del título preliminar del Código Civil, al regularse mediante el presente Texto Único Ordenado íntegramente las materias sobre Libertad Sindical, Negociación Colectiva y Huelga, quedan derogadas todas las disposiciones que se opongan o sean incompatibles con la presente norma.

Tercera.- El Ministerio de Trabajo y Promoción del Empleo, queda encargado de elaborar el Reglamento de la Ley de Relaciones Colectivas de Trabajo, que consolide las normas reglamentarias sobre la materia.

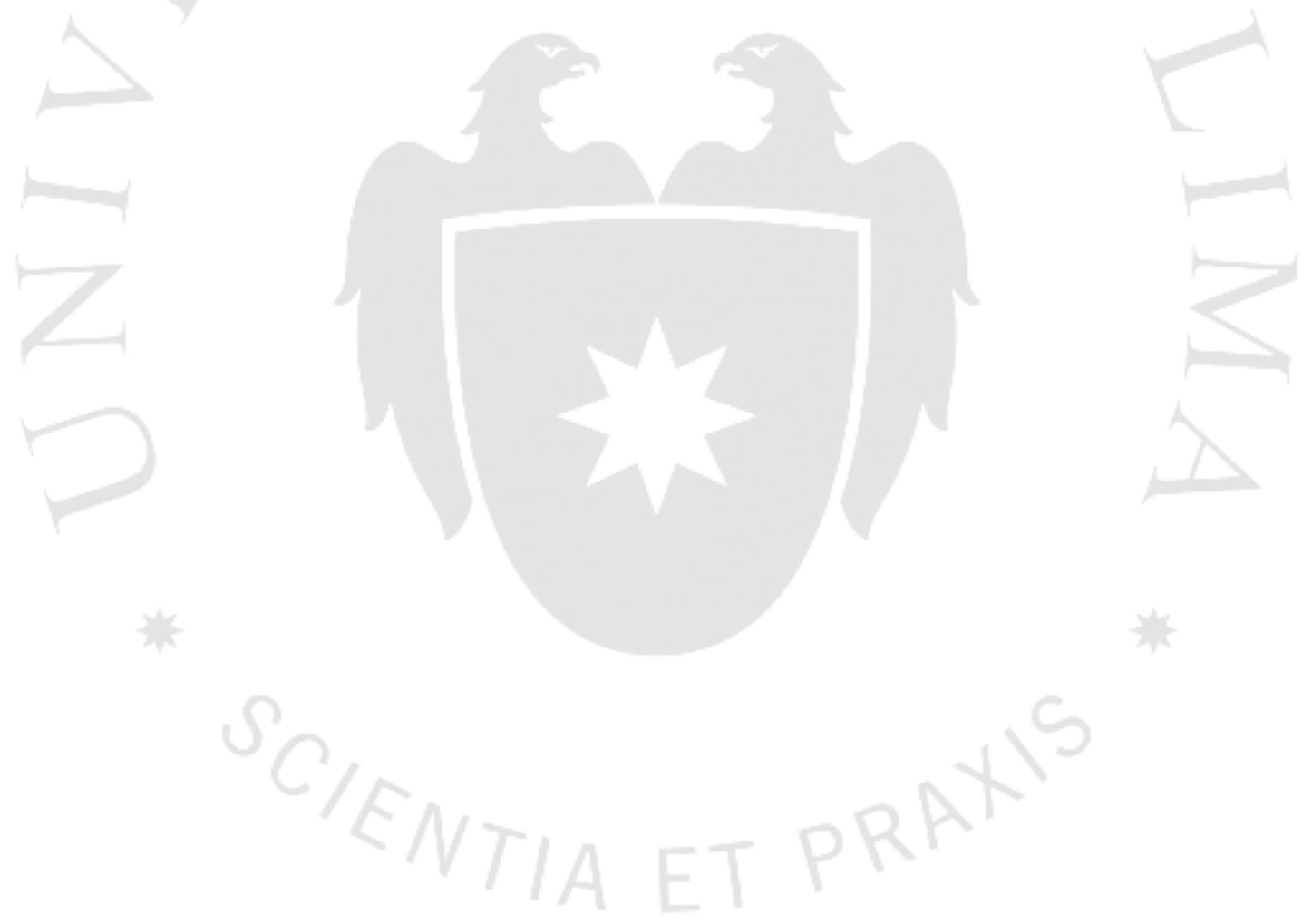




\section{Anexo N 7}

Sentencia del Tribunal Constitucional recaído en el Expediente $\mathrm{N}^{\circ}$ 00018-2013-PI/TC respecto a la constitucionalidad de la Ley 30057, Ley del Servicio Civil 


\section{Anexo $\mathbf{N}^{\circ} 8$}

Sentencia del Tribunal Constitucional recaído en el Expediente $\mathrm{N}^{\circ}$ 003-2013-PI/TC y otros respecto a la constitucionalidad de diversos artículos de la Ley de Presupuesto General de la República 
Anexo $\mathbf{N}^{\circ} 9$

Sentencia del Tribunal Constitucional recaído en el Expediente $\mathrm{N}^{\circ}$ 0025-2013-PI/TC respecto a la constitucionalidad de diversos artículos de la Ley 30057, Ley del Servicio Civil 